
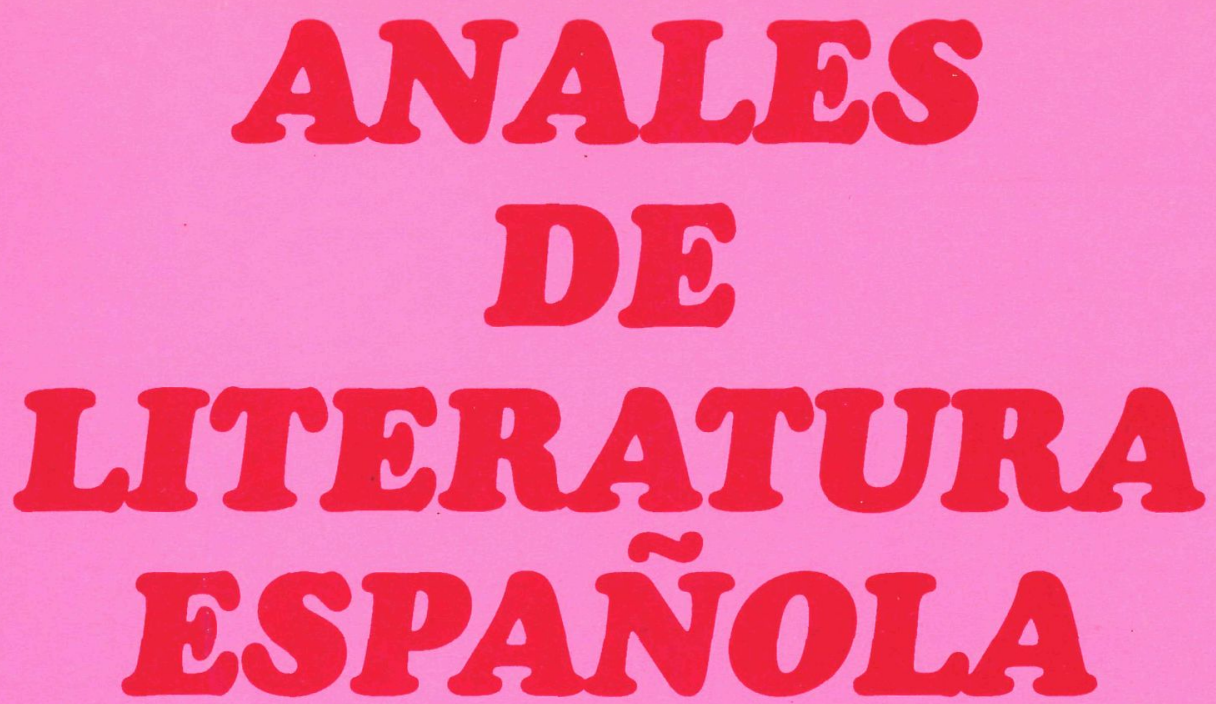

UNIVERSIDAD DE ALICANTE - No 8, I992

Jovita BOBES NAVES

Recurrencias temáticas en la novela hispanoamericana (I)

José Luis CALVO CARILLA

La heroína modernista (la mujer finisecular en las novelas de Llanas Aguilaniedo)

Marta CRISTINA CARBONELL Las Exequias de la lengua castellana de Juan Pablo Forner, "sátira menipea"

\section{Jorge DEMERSON}

Leandro Fernández de Moratín y José de Lugo en Londres (1792-1793)

\section{Eva F. FLORENSA}

El Niño de la Bola y la fisiología de la novela decimonónica (II)

\section{Jordi GRACIA}

Ingredientes modernistas de un postromántico: V.W. Querol

\section{Librada HERNÁNDEZ}

Clarín, Galdós y Pardo Bazán frente al teatro de José Echegaray

Gregory B. KAPLAN

The other major source of Huerta's Raquel: Esther

\section{Renata LONDERO}

Aspetti delle teorie romantiche inglesi in Cernuda

Antonio MARCO GARCÍA

El Modernisme, heredero de la estética romántica. A propósito de dos cartas de Santiago Rusiñol a Víctor Balaguer

Josep María SALA VALLDAURA Bases y tópicos morales de los sainetes de Ramón de la Cruz

\section{Russell P. SEBOLD}

Periodización y cronología de la poesía setecentista española

Pedro Pablo VIÑUALES

Mi Entierro de Clarín: un cuento raro 



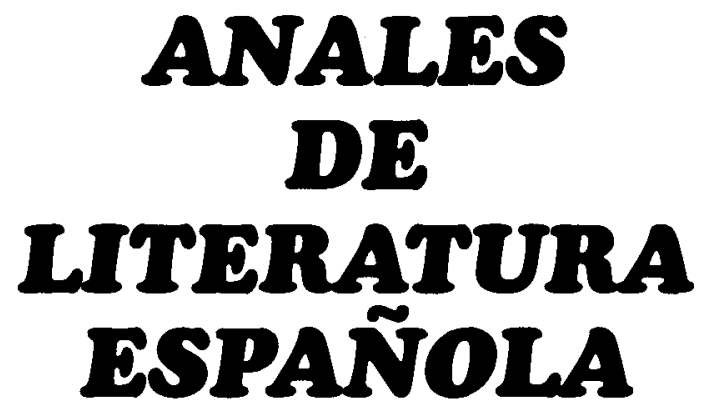


Anales de la Universidad de Alicante

Literatura Española

Director: Guillermo CARNERO ARBAT

Secretario: Enrique RUBIO CREMADES

Consejo de Redacción: Departamento de Literatura Española de la Universidad de Alicante 


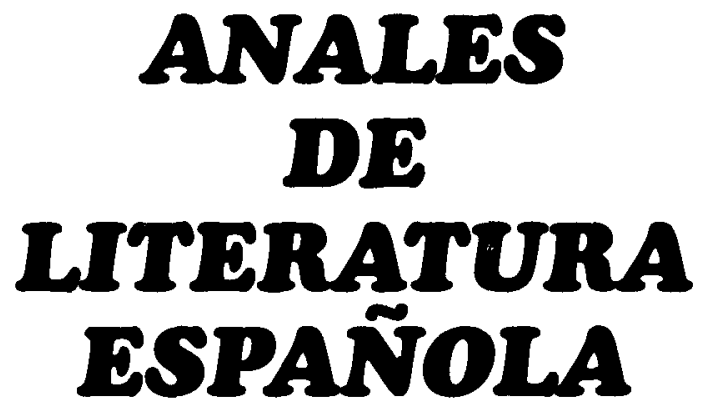

UNIVDRSIDAD DE ALICANTY - No 6, 1992 
. 


\section{ÍNDICE}

Jovita BOBES NAVES

Pág.

Recurrencias temáticas en la novela hispanoamericana (I) . .

José Luis CALVO CARILLA

La heroína modernista (la mujer finisecular en las novelas de Llanas Aguilaniedo) . . . . . . . . . . . .

Marta CRISTINA CARBONELL

Las Exequias de la lengua castellana de Juan Pablo

Forner, "sátira menipea" . . . . . . . . . . . . .

Jorge DEMERSON

Leandro Fernández de Moratín y José de Lugo

en Londres (1792-1793) . . . . . . . . . . . . . . . .

Eva F. FLORENSA

El Niño de la Bola y la fisiología de la novela

decimonónica (II) $\ldots \ldots \ldots \ldots \ldots \ldots \ldots \ldots \ldots \ldots \ldots \ldots \ldots \ldots$

Jordi GRACIA

Ingredientes modernistas de un postromántico:

V. W. Querol . . . . . . . . . . . . . . . . . .

Librada HERNÁNDEZ

Clarín, Galdós y Pardo Bazán frente al teatro de

José Echegaray . . . . . . . . . . . . . . . . . .

Gregory B. KAPLAN

The other major source of Huerta's Raquel: Esther . . . . . . .

Renata LONDERO

Aspetti delle teorie romantiche inglesi in Cernuda . . . . . . .

Antonio MARCO GARCÍA

El Modernisme, heredero de la estética romántica. A propósito de dos cartas de Santiago Rusiñol a Víctor Balaguer . . . . . . . .

Josep María SALA VALLDAURA

Bases y tópicos morales de los sainetes de Ramón

de la Cruz . . . . . . . . . . . . . . . . . . . . . . . . . 
Russell P. SEBOLD

Periodización y cronología de la poesía setecentista

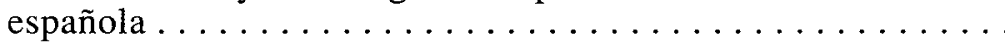

Pedro Pablo VIÑUALES

Mi Entierro de Clarín: un cuento raro . . . . . . . . . . . . . . . 193 


\title{
RECURRENCIAS TEMÁTICAS EN LA NOVELA HISPANOAMERICANA (I)
}

\author{
Jovita BOBES NAVES \\ Universidad de Oviedo
}

\section{Panorama}

La novela hispanoamericana trata recurrentemente un tema: el poder. Sus variantes textuales se pueden agrupar por los rasgos destacados en cada ocasión.

a) El poder se encarna en un personaje, el dictador, que lo ejerce despóticamente y da origen a las "novelas de dictador" que desde el siglo pasado llegan hasta hoy. Muchos de sus rasgos repetidos se han convertido en verdaderos signos del género y se encuentran en casi todos los relatos de este tipo.

b) En las novelas indigenistas, un pueblo o raza ha sido y es sojuzgado por el blanco o el criollo. Los conflictos que presentan son los de un grupo social frente a otro que se aprovecha de las ventajas de leyes realizadas a espaldas de los indios y sin contar con sus costumbres y tradiciones.

Como variantes están las novelas en que indios y criollos son explotados por los yankees, en haciendas agrícolas, mineras e industriales realizadas de forma primitiva por los indios, y científica y racionalmente por los foráneos.

c) Las novelas de espíritu revolucionario, en las que la situación de estudiantes, indios, civiles, pueblo en general, es tan desesperada que se revuelven contra los tiranos o los explotadores. Los más preparados culturalmente de los marginados, con ideas revolucionarias, casi siempre de origen marxista, hacen suya la tarea de aprovechar el descontento de todos y actúan contra los que detentan el poder: gobiernos, grupos yankees, grupos sociales que conservan el poder feudal, etc.

Caso especial es el de algunas novelas mejicanas actuales, aparte las llamadas de revolución, al tratar el problema del partido único y la designación 
de candidato presidencial que actuará de tirano mientras dure su mandato. La oligarquía, recién estrenada de la industria, condiciona la vida y la política de un pueblo. Se llega a la imposición de un dictador por otro que en apariencia se ocupa de actividades comerciales e industriales.

Esquematizados los diferentes tipos novelísticos tenemos:
A) Novelas de dictador
B) Novelas indigenistas y de explotación de extranjeros sobre los autóctonos.
C) Novelas de espíritu revolucionario.

Los recursos repetidos pueden formalizarse de tal modo que se convierten en verdaderos signos literarios cuyo significado es siempre el mismo: el dominio del hombre por el hombre.

Las variaciones son múltiples, pero se mantiene en cada creación un número de rasgos diferenciadores que producen una suerte de intertextualidad (Angenot, 1983) que afecta a la construcción misma de la novela. Se crea un horizonte de expectativas que permite al escritor la condensación de enunciados sugeridos más que realmente materializados en cada obra.

En estas novelas el poder sería el contenido significativo o idea común que se manifiesta a través de diferentes formas.

\section{Elementos Comunes}

Las novelas del poder presentan elementos comunes desde el punto de vista de su tratamiento en el discurso: entre ellos destaca el espacio. El marco para todos los relatos es el de las tierras americanas o macroespacio genérico; pero de él se desglosan espacios más reducidos y concretos en cada clase de relato: son los micro-espacios ambientales, significativos para el desarrollo de la anécdota concreta.

En las novelas del dictador la ambientación preferente es urbana, sobre todo una vez conseguido el poder; el campo o pequeños núcleos de población rural aparecen en las novelas que tienen por protagonistas a los indios o criollos. Urbanas o rurales son las ambientaciones de las novelas revolucionarias, incluso recorren países enteros para propagar ideas, como en Mascaró, el cazador americano de $\mathrm{H}$. Conti, y en ocasiones países distintos al de procedencia del autor, en Hispanoamérica o en Europa, como en Días y noches de amor y de guerra de E. Galeano, o en el Libro de Manuel de J. Cortázar.

Otro elemento común es la presentación del pueblo dividido en dos clases, los tiranos y los tiranizados, protagonistas individuales o colectivos, pero 
siempre como seres que ejercen o sufren el poder.

El tiempo es otro de los elementos comunes significativamente tratado. Las innovaciones técnicas en el uso de este elemento son especialmente privilegiadas en algunos relatos.

En muchas novelas un gran abigarramiento de materiales proporciona un barroquismo que se ve favorecido por el recurso de la intertextualidad, utilizado como elemento básico para la creación novelesca. Su valor significativo es notable. Todos los autores se sirven del procedimiento como si la novela fuese "algo que deviene, como un proceso", cuyo estudio debe plantearse como el de "un diálogo de múltiples textos, como un diálogo textual, o, mejor dicho, como una intertextualidad" (Kristeva, 1974, pág. 22).

Las distintas clases de novelas siguen hoy fieles a los elementos fundamentales que las caracterizan, pero su formalización es tan notable que hay tendencia a unificar y mezclar los distintos signos en una versión integradora que resulta un compendio de experiencias, vividas por un solo individuo como podemos ver en la obra de I. Allende, Eva Luna. A través de ellas se alcanza una síntesis del ser de estos países. La narradora actúa como la conciencia que filtra la realidad inmaterial del ser de Hispanoamérica. El "yo" que habla y cuenta su experiencia es real en la locución y crea un mundo de ficción que refleja, a través de la narración, la realidad del mundo en que se escribe. El personaje central, como el pícaro, recorre y unifica distintos ambientes sociales y modos de vida que enlazan la tradición con el mundo actual donde pulula una mezcla de razas, clases sociales y niveles económicos y culturales diversos.

El autor puede cambiar el punto de vista o la perspectiva desde la que contar o narrar los hechos que constituyen el mundo de la novela, aunque "también este mundo se crea a sí mismo a través de él, lo transforma en sí mismo, le obliga a entrar en el juego de las transformaciones, para manifestarse mediante él" (Kayser, 196l, pág. 468).

La materia de las novelas hispanoamericanas está a la vista de todos, y esperando que los autores la tomen y la elaboren como materia narrativa: "hay una cierta materia que quiere decirse; y en un sentido no es el novelista quien hace la novela, es la novela la que se hace sola, y el novelista no es más que el instrumento de su venida al mundo, su partero" (Butor, 1960, pág. 273).

Muchas de estas novelas, sobre todo las de dictador, recurren al artificio de que no están escritas por el autor, sino por personajes más o menos próximos al círculo del tirano, o por este mismo.

En las novelas de F. Ayala Muertes de perro y El fondo del vaso, son dos espectadores de la tiranía, Pinedo y José Lino respectivamente, los que arti- 
culan los relatos con variadas formas: recopilaciones, confidencias, diarios, artículos de periódicos, etc.

En otras, como Yo, el Supremo de A. Roa Bastos, el relato aparece como la obra dictada por el tirano a su secretario Patiño, e intercala notas que se fingen escritas por el mismo Supremo.

En Oficio de Difuntos de A. Uslar Pietri, es el padre Solana el que cuenta la historia a partir de la muerte del dictador.

Otras veces es un narrador desconocido el que va contando y comentando los acontecimientos, a la vez que juzga los actos de la tiranía.

Todas estas variaciones permiten al lector acercarse al tema desde ángulos diversos que proporcionan enfoques próximos, medios o lejanos, para interpretar y juzgar libremente los acontecimientos y sus consecuencias.

En ocasiones varias voces cuentan los mismos hechos, lo que proporciona perspectivas que se entrecruzan y pueden ser sucesivas o simultáneas.

En Conversación en la Catedral de M. Vargas Llosa, aparecen sucesivamente el relato de Amelia y el de Ambrosio, a través de lo que este último va contando a Santiago. Son los mismos hechos pero no la misma perspectiva, y se manifiesta con variaciones simultáneas al utilizar un recurso en los diálogos consistente en entrecruzar intervenciones de distintos personajes y distintos tiempos en relación con temas comunes. Es lo que J. M. Oviedo denomina diálogos telescópicos, corte continuo y acotaciones dramáticas.

Estos recursos técnicos proporcionan variedad al resultado de la creación artística y al lector modos nuevos de contemplar lo ya conocido y participar activamente en la obra de arte.

La novedad de estos recursos está en relación con el tema: más actualizados son los de la novela del dictador o las de espíritu revolucionario, más tradicionales los relatos de tema indigenista.

En las novelas más recientes de temática revolucionaria se puede llegar a una aproximación a otros géneros como el ensayo o el género dramático.

El uso de tales recursos, unido a la intertextualidad, proporciona una intelectualización del relato, en el que los autores se permiten licencias artísticas, participando como personajes conscientes y críticos, y como actores interesados en el drama que viven sus respectivos países.

De los elementos de construcción o recursos comunes destacaremos cuatro fundamentales, que presentan variaciones en su tratamiento en los distintos tipos de novela, y son: los personajes, el espacio, el tiempo y la intertextualidad. 


\section{Los personajes}

En las novelas de dictador la figura omnipresente en el relato, aunque no necesariamente como protagonista, es la del tirano. De él emana el poder, una clase abusiva de poder, que ejerce directamente o a través de una figura interpuesta que actúa como "factotum".

Diversos estudios sobre esta clase de novelas permiten su identificación, al destacar una serie de rasgos de construcción que se reiteran en autores y obras.

A veces, el tirano aparece en todos los capítulos, como en Yo, el Supremo de A. Roa Bastos; otras sólo en algunos como en El Señor Presidente de M. A. Asturias. Su manera de actuar es, en todas, igual; su modo de ejercer el poder, también. Trata con la misma indiferencia un motivo sin importancia o la vida de un hombre, en cualquier caso es su voluntad la que siempre se impone. Todo lo que se le antoja se convierte en ley, pues las que pueden existir en su país no son obstáculo para hacer su voluntad. Nadie se pregunta si lo que ha ordenado el jefe está bien o mal, no se analiza, se ejecuta y con ello se procura hacer también lo que a cada uno le conviene. Todos buscan prebendas y dádivas, y procuran evitar castigos y condenas, que, cuando llegan, tampoco pueden eludir. Todo irradia del mismo foco, el tirano, que, por los nombres o apelativos que recibe, queda marcado desde el principio como centro de referencias y actitudes.

La conjunción de personaje, espacio y tiempo es determinante en este tipo de novela. Una vez desaparecida la circunstancia que une estos elementos esenciales de la narración, ésta se termina o desaparece, incluso cambia el tipo de narración, como se ve en ciertas novelas donde al sustituir alguno de los ingredientes habituales se desvirtúa su valor prototípico. Cuando El Supremísimo (Alonso, 1981) se desplaza a la selva pierde parte de sus características, aunque mantiene la visión irónica que es frecuente en los autores que tratan el tema. La parodia es tan burda que se acentúa la burla de una actuación, aunque trágica, inverosímil, al hacerse truculenta. El espacio, que no es el habitual, se apodera del personaje, impidiéndole actuar a su antojo. Las fuerzas de la naturaleza no le obedecen, son indiferentemente superiores.

En la misma novela se hace alusión a otro tirano, anterior al protagonista, y para el que ha terminado el tiempo de tiranía al ser desplazado fuera del país; su vida actual es la de un mendigo en Nueva Orleans. El tiempo y el espacio condicionan la actuación y fuera del contexto creado se acaba el personaje tirano. En ocasiones, el desplazamiento del dictador es voluntario, pero, también así, perderá su poder y para recuperarlo habrá de volver a la patria y pelear contra el que se lo ha arrebatado en su ausencia. Lo comprobamos en El re- 
curso del método de A. Carpentier. El personaje que habla en este relato, el tirano, se desplaza a Nueva York y a París, donde se comporta como un nuevo rico, más o menos caprichoso, pero no puede, como en su país, imponer su voluntad a nadie, ni siquiera a sus hijos. Cuando le anuncian que le han arrebatado el poder político, vuelve a su país y lucha de nuevo por él.

Acompaña al tirano un ejecutor de sus órdenes o "factotum", con el que habla cuando quiere mostrar sus pensamientos, que son interpretados casi sin enunciarlos. En Amelia (Mármol, 1984), es una mujer de la familia del tirano la que actúa como intérprete de la voluntad de Rosas.

A veces el "factotum" da su visión de la dictadura, lo que proporciona variedad al punto de vista. Las diferentes visiones condicionan el desarrollo del tema.

La figura del tirano lo preside todo, aunque no aparezca en muchos episodios, como en la obra de M.A. Asturias, El Señor Presidente, o en la de M. Vargas Llosa, Conversación en La Catedral, donde las innovaciones técnicas del discurso no impiden observar una sociedad en la que apenas aparece como personaje el tirano Odría (personaje real de Perú, que gobierna en 1948-56).

La novela puede ofrecer en este sentido - presencia o latencia del dictador- discursos diversos, variados.

No es un mundo normal el que engendra la dictadura, y para conseguir esta impresión la ficción deforma y distorsiona sus componentes, creando un mundo con personajes animalizados, muñequizados, movidos por sentimientos de temor o miedo, que les hacen actuar de manera grotesca. Esta visión deshumanizadora actúa sobre los personajes tanto si ejercen el poder como si lo padecen.

El sentimiento religioso, que se manifiesta muchas veces sedimentado en el lenguaje, resulta en estas situaciones una verdadera burla o parodia que aprovecha las circunstancias a gusto y acomodo del tirano, dándole una significación desviada para justificar actuaciones equívocas, fraudulentas. Los mismos tiranos son, con frecuencia, o como Luzbel, "aquel gran Luzbel sin fuego y sin eternidad como decía Solana" (Uslar Pietri, 1976, pág. 201), o como el Señor, o Supremo, en El Señor Presidente de M.A. Asturias o en Yo el Supremo de A. Roa Bastos. Esta condición sobrenatural también se da en personajes allegados a él, que se presentan como ángeles vengadores.

Los tiranos durante su mandato se asocian con todas las fuerzas sociales que les pueden hacer competencia y eliminan con su actitud los posibles brotes de oposición. Pero sus prebendas duran sólo lo que dura su poder,si éste se acaba, como se pone de manifiesto en las épocas de transición. 
Los autores suelen recurrir a escenas tópicas, donde se hace evidente la actitud del tirano, para mostrar la tiranía. Señalaremos:

a) Escenas que muestran las relaciones con la mujer y los hijos, origen, en muchos casos, de fatales consecuencias para el tirano..

b) Escenas con los miembros del gobierno, en las que se destaca la arbitrariedad del mandato tiránico. Es ejemplar en este sentido la escena de Bocanegra reunido con sus ministros en el cuarto de baño (Ayala, 1972). El lugar elegido pone de manifiesto la abyección de esta relación ignominiosa para los ministros que le rinden pleitesía y para él mismo, que lo consiente y lo estimula. El lugar comunica metonímicamente su degradación a la escena allí situada.

c) Los desfiles militares en los que el dictador se complace en mostrar su superioridad física. Escenas de este tipo aparecen en La fiesta del rey Acab de E. Lafourcade, o en Muertes de perro de F. Ayala.

d) Los negocios abusivos y sucios se presentan en relación con los montados por sus inmediatos seguidores con prostitutas y garitos; el tirano y sus adláteres, en su afán desmedido de lucro, permiten la degradación del hombre, si ello significa ganancia. Situaciones semejantes se ven en La fiesta del rey Acab, El Señor Presidente, o en Conversación en La Catedral.

e) Admiración frecuente por pesonajes de la historia que encarnan el ideal del mando supremo. Napoleón es uno de estos héroes. Hitler o César aparecen en otras ocasiones. En El Supremísimo, el tirano entabla una especie de competición con la historia de Napoleón al que sigue hasta el final; en Yo el Supremo de Roa Bastos se repite este afán imitativo. En El discurso del método, la erudición del primer mandatario le sugiere múltiples formas de alusiones a personajes históricos para usarlos en su propio beneficio.

f) Escenas en las que aparece el opositor al poder tiránico, que puede estar encarnado en personajes supervivientes de los antiguos linajes que ostentaban el poder feudal, estudiantes movidos por idealismos utópicos, los propios compañeros de mando que en un momento de debilidad del dictador se apoderan del aparato del poder en favor suyo, o los militares que se alzan en armas contra el tirano para imponer otra dictadura militar.

En algunos autores se observa el interés por analizar el proceso que va desde la oposición al tirano y las ansias libertarias de la juventud, al deseo de mandar sobre los demás. Así ocurre con el "estudiante" de El discurso del método, que sigue un proceso desde la revuelta juvenil a la participación en el régimen.

Como elementos ambientales se reiteran los actos públicos y solemnes en instituciones artísticas y académicas, donde los integrantes parecen rivalizar en 
alabanzas al tirano; la relación en tabernas o sitios públicos con el pueblo, el cual se presenta amorfo, sin individualizar; situaciones límite para la crueldad innecesaria y gratuita del dictador que no reconoce más ley que su capricho, actitud que tiene poder de imitación en los que le rodean, lo que convierte el círculo del tirano en un círculo dantesco de opresión y crueldad. En Muertes de perro, Tadeo Requena mata en el W.C. presidencial un perro amaestrado que le ha traído Luisito Rosales para obsequiar a Bocanegra y parece desencadenar con ello la locura del ministro y su suicidio; en Amelia, se asiste a una ejecución sumaria de un vendedor ambulante sólo porque molesta a Rosas el alboroto que provoca la tropa contra él, al creerlo espía; en El Señor Presidente, éste manda azotar a un subordinado por no realizar las órdenes a su gusto, y cuando le comunican que ha muerto, el Presidente muestra una total indiferencia. Otras veces son las brutalidades rebuscadas con los presos las que muestran la crueldad arbitraria y hasta chusca del dictador.

A veces el tirano puede aparecer como personaje dominante de una república sin ser titularmente gobernante, pero con un poder omnímodo capaz de imponer al titular que le conviene para sus negocios y manejar a los jefes de gobierno como marionetas que actúan según su deseo. El ejemplo más claro lo constituyen las novelas de L. Spota Retablo hablado, donde se presenta, partiendo del momento de su muerte, a Eugenio Olid en su ascensión al poder económico que le permite convertirse en un "auténtico sátrapa de la vida política mexicana, amo y señor del país, en cuyas manos rapaces confluyen los destinos de la nación. La inexcusable presencia del dictador o del presidente autocrático (títeres u hombres de paja del todopoderoso Olid) no se hace esperar" (Calviño, 1985, pág. 125). En Palabras mayores, "viene a representar una especie de amplificación secuencial y angular de la obra anterior por cuanto el tema gira en torno del problema sucesorio a la Presidencia" (ibid.).

El tirano pueblerino aparece en Pedro Páramo de J. Rulfo o en Siete lunas $y$ siete serpientes de D. Aguilera Malta, donde el protagonista se presenta dividido; por una parte el jefe político o cacique y por otra el jefe militar que se nombra a sí mismo coronel y se impone arbitrariamente al pueblo por la fuerza de las armas. Viene esto a confirmar la teoría de que el militarismo o caudillismo es el germen del tirano y de su dictadura (Morales Padrón, 1962).

En Gracias por el fuego de M. Benedetti, el personaje R. Boudiño cuenta su vida y la relación con su padre, tirano familiar y social, a través del periódico que dirige "... la historia moderna uruguaya resulta filtrada a tenor de la crónica familiar en la que Boudiño (el viejo) representa la crapulosidad de un sistema que actúa a costa y de espaldas al pueblo; su figura es la de un tiranuelo de vaudeville, sin escrúpulos ni miramiento alguno" (Calviño, 1985, pág. 155).

En La muerte de Artemio Cruz de C. Fuentes, también el personaje central 
se presenta como un tirano de su entorno familiar y social, que surge, como es frecuente, de una revolución previa y se erige en nuevo tirano, o por lo menos en la nueva oligarquía que favorece la tiranía.

En las novelas indigenistas, los personajes suelen ser colectivos; a veces destacan individuos pero siempre prototípicos del pueblo que representan.

En estos relatos se describe la vida monótona pero idílica de una comunidad, con su sistema de vida y de autogobierno. Participan todos en las asambleas (hombres, claro, las mujeres no cuentan), y en los bienes comunes. Destacan las relaciones familiares y afectivas, la naturalidad espontánea de estas relaciones, la ignorancia del sistema de vida de los blancos y la repercusión de las leyes de éstos en las comunidades.

Se analizan también los modos de trabajar la tierra, de cuidar los rebaños, que son los principales medios de subsitencia en las comunidades rurales y de montaña, o su trabajo en las minas, o en las plantaciones explotadas por los extranjeros.

En sus creencias permanecen ritos ancestrales mezclados con el cristianismo, creando un sincretismo religioso en el que destaca la creencia en la transformación de los hombres en animales, nahualismo, mito que con frecuencia utilizan los autores con sus protagonistas. Estos, generalmente analfabetos, se guían por los conocimientos que les proporcionan sus tradiciones, la observación de la naturaleza y de sus fenómenos cíclicos. Su vidas es más natural y menos sofisticada que la de los blancos, son más "ingenuos" en el sentido filosófico del término.

A los indios se les integra en el sistema de vida de los blancos, arrancándoles a la fuerza de sus comunidades para llevarlos al ejército o a los puestos de trabajo obligatorio. Se ponen en contacto con otros hombres y con ideas que les permiten la defensa de su sistema de vida como un bien cultural que se debe mantener.

Las mujeres aparecen en la comunidad sin voz y sin posibilidades de manifestación o de desplazamientos que les permitan un mayor conocimiento y de sus derechos. Siguen a sus hombres y viven para cuidar de ellos y de los hijos.

Todo esto se puede observar en obras como la de C. Alegría El mundo es ancho y ajeno, o Los perros hambrientos. En El indio de G. López Fuentes, la raza es la protagonista, sin nombres propios. Presentan el mismo sistema de vida, aunque se desarrolla en espacios muy distantes y diversos geográficamente.

Las diferencias entre indios y blancos se manifiesta en obras como Los ríos profundos de J. María Arguedas, a través de un niño blanco educado por indios, 
que al integrarse en el colegio con otros muchachos siente el trauma de las diversas culturas.

Las obras de M. Scorza pertenecientes a la pentalogía La guerra silenciosa se desarrollan en los Andes centrales, y los protagonistas son los indios de la región, despojados de sus tierras por el latifundismo de corte feudal que pervive todavía, o por las compañías yankees que explotan la minería de la zona.

Cuando un personaje se destaca de la masa amorfa de los indios para su defensa es porque en él se sienten representados todos los indios, como ocurre en Garambo, el invisible, en quien renacen diversas tradiciones. Cuando desaparece surge Agapito Robles, que actuará como nuevo héroe en el Cantar de Agapito Robles, con resonancias épicas ya desde el título.

Son novelas que no representan la lucha individual sino colectiva de la raza aborigen de cualquier parte de Hispanoamérica. Así lo confirman las palabras de C. Alegría: "La intención de llevar al indio a la novela, pese a las obras que tenía ya publicadas, me hacía confrontar dos problemas difíciles. El primero: mostrar el espíritu indígena, lo que implicaba un tratamiento novelístico de personajes. El segundo, según el tema que me había propuesto: presentar a un pueblo entero sin que se debilitaran los personajes" (Alegría, 1968, pág. 11).

En Huasipungo de J. Icaza se repite el mismo protagonismo de los indios del Perú.

En estas obras el indio no tiene voz, se la da el narrador, que no suele ser nunca indio, sino un observador extraño que recoge los motivos tradicionales y actuales de la desesperada situación de la raza. Este narrador es omnisciente para dominar desde su conocimiento la situación que le permita presentar la vida del indio con una perspectiva global.

Los problemas planteados en cada comunidad son variados y se llega a las luchas legales como en Redoble por Rancas o en El mundo es ancho y ajeno, de M. Scorza y de C. Alegría respectivamente.

Los protagonistas de las novelas de ideas revolucionarias suelen ser grupos, y cuando se destaca algún personaje es cabecilla prototipo, un estudiante o intelectual movido por una ideología de origen europeo que encauza la difícil situación de los países hispanoamericanos para desembocar en un movimiento de masas. En las relaciones de grupo se crean situaciones confusas, llegando a extremos como no saber la razón por la que se lucha, o hacerlo entre grupos de la misma ideología que parecen no encontrar nada mejor en qué aparentar acción. La obra de O. Soriano No habrá más penas ni olvido narra el enfrentamiento a muerte entre diversos personajes del mismo partido peronista que luchan ferozmente entre sí, hasta que interviene el ejército para calmar los ánimos, tras una serie de 
muertes y torturas increíbles. Crueldad gratuita que parece explicar lo inexplicable de una situación caótica que engendra violencia. Los hechos se sitúan en Argentina durante el último gobierno de Juan Domingo Perón.

En este tipo de novela siempre aparecen como contrapersonajes las fuerzas de orden público, abusando de su autoridad con torturas que son el objeto de la narración y que ponen de manifiesto la arbitrariedad del poder. En ocasiones son fuerzas paramilitares o grupos honorarios los que actúan impunemente amparados por la policía oficial.

Los personajes analizan interiormente sentimientos, recuerdos, preparación y esperanzas que suscita la acción, y las consecuencias que puede traer.

También es frecuente la observación, desde fuera, de la situación del país. Desde el destierro o el alejamiento temporal se ve con añoranza la lucha interior y el planteamiento de acciones que modifiquen la vida de todos. A veces estas reflexiones se hacen transcendentes al interrogarse los personajes sobre el ser de su patria, de su raza, o de sus hombres, analizado desde la historia que desemboca en el ser actual. Así ocurre en La región más transparente de C. Fuentes, o en Los convidados de piedra de J. Edwards, muy distintas en su realización, pero con el deseo común de analizar la situación y el ser de sus respectivos países en el momento actual: México y Chile.

En otras novelas revolucionarias es frecuente la presencia de un personaje itinerante que aparece y desaparece, enlazando y preparando acciones revolucionarias en distintos puntos de la nación, que alcanzan repercusión general. Los ojos de los enterrados de M.A. Asturias funde los temas de la tiranía y la explotación de las compañías bananeras y en la meditación final de uno de los personajes se analiza la lucha contra las dos: "La Dictadora y la Frutera caían al mismo tiempo y ya podían cerrar los ojos los enterrados que esperaban el día de la justicia...".

La figura revolucionaria del opositor se presenta con rasgos semejantes y denominaciones genéricas como "el estudiante", etc.

Las novelas unen personajes y actitudes que se completan, se relacionan y se reiteran en el panorama de los países hispanoamericanos, de los que se novela una realidad continuada en el tiempo, como se pone de manifiesto en Vista del amanecer en el trópico de G. Cabrera Infante.

\section{Espacio}

El espacio geográfico de los distintos países hispanoamericanos suele ser el marco genérico de cualquiera de los tipos de relatos tratados. 
Los espacios de la novela de dictador son distintos en los diversos autores, pero mantienen unas características comunes que permiten unificarlos en el sentido que tienen respecto al tema.

Todos los relatos de dictador se presentan en países reales o imaginarios de Hispanoamérica, recreada como un mosaico de espacios menores que al unirlos articulan el espacio genérico.

En la articulación de los micro-espacios predominan los urbanos y dentro de ellos el palacio presidencial, en la capital de la nación. En alguna obra se proporcionan espacios rurales correspondientes a los episodios del pasado, anteriores a la consecución del poder, o en la lucha por él.

Los micro-espacios concretos de cada novela no suelen precisarse, sin embargo, en ciudades identificables por indicios de realidad. La ambigüedad ambiental parece ser propia de la mayoría de estos relatos, que pretenden con ello una generalización.

En el círculo del poder tiránico se destacan diversos espacios menores y se crean una serie de cuadros yuxtapuestos que logran un fragmentarismo de piezas diseminadas que después encajarán en el rompecabezas que el lector recompondrá si quiere articular el mundo del tirano y de la tiranía.

Los espacios seleccionados están en función de los distintos aspectos sociales y de los valores que se quieren analizar: clases sociales, estamentos, grupos de poder (económico, religioso, militar, cultural), relaciones familiares, ambientes marginados, etc.

R. Gullón, al analizar el espacio en Tirano Banderas, señala la especialización intensa y añade: "Se ha dicho de Tirano Banderas que es una novela cubista y en el texto se hallan referencias directas al modo cubista de contemplar la realidad. Cubismo en este contexto, no sólo quiere decir fragmentación de la realidad, sino función representativa (metonimia, diría Jakobson) en cada uno de los fragmentos; el espectador - o lector - tiene que decodificarlos y reconstruir mentalmente la totalidad" (Gullón, 1980, pág. 58).

Lo mismo se puede aplicar a casi todas las novelas de dictador que utilizan el espacio fragmentado con un valor metonímico que comunica su sentido a la escena en él desarrollada y más aún a la tiranía en general. Una recepción en palacio, donde rinden culto al tirano los invitados selccionados para que lo hagan, significa el abigarramiento y la degradación de estos personajes de variada procedencia pero con el deseo común de figurar cerca del poder para conseguir sus ambiciones y medro personal por encima de la propia dignidad. Aparecen escenas de este tipo en La fiesta del rey Acab, en Amalia, en Muertes de perro o en El otoño del patriarca, etc. 
Los espacios de palacio, senado, Universidad, iglesia, donde se dan escenas en que interviene como protagonista el tirano, muestran la alucinante y obsesiva omnipresencia del poder tiránico en todos los puntos clave de la vida de un país dominado por la mirada de un individuo que se enfoca y proyecta sobre todo.

Las personas que no desean participar de la tiranía han de alejarse de los espacios controlados por la mirada del tirano o de sus colaboradores, donde sólo algunos inocentes o locos pueden actuar impunemente: el cura de Santa Rosa y el hijo de Luisito Rosales en Muertes de perro, o Bendición Alvarado en El otoño del patriarca; pero no siempre, como se ve en Señor Presidente.

Estos espacios de la tiranía son con frecuencia intertextuales, lo que no resta originalidad a la visión que del tema consigue cada autor.

Estas novelas, como todas, "modelizan un objeto infinito (la realidad) a través de los medios de un texto finito, la obra de arte sustituye con su espacio no una parte de la vida representada, sino la vida en su totalidad. Cada texto aislado modeliza simultáneamente un objeto particular y un objeto universal" (Lotman, 1982, pág. 263), y el conjunto de las obras que tratan un tema del que cada una constituye una visión particular, reiteran, sin embargo, elementos comunes que se hacen imprescindibles en el reflejo de una realidad que pasa a ser modelo universal. La visión se repite una y otra vez sobre el tiempo que va entre conseguir el poder y perderlo, generalmente a la vez que se pierde la vida. El novelista presenta el espacio vital desde el comienzo o desde el desenlace, lo que no tiene demasrada importancia, porque en cualquiera de los casos lo que intenta es poner de manifiesto que el poder tiránico tiene en sí mismo el principio del fin y éste llega como consecuencia lógica con el paso del tiempo.

El espacio de las acciones del tirano es aquel en el que destacan las características del despotismo, por eso es parte del desarrollo sintáctico del tema y queda condicionado por él, a través de la visión de los personajes, del narrador o del autor.

Para F. Aínsa "el paisaje ha ido dejando de ser el transfondo sólido de la novelística del mundo de cada día, para pasar a ser el complemento necesario de una acción significada en un sentido particular" (Aínsa, 1976).

Esta tesis se verifica en las novelas del dictador, cuya articulación de espacios en un sistema coherente crea un mundo alucinante que se debate entre dos extremos que se oponen, cielo e infierno, según la mirada que ilumina la escena y actúa de coordinadora de esa multiplicidad de espacios. Es la mirada, creo, lo que permite "atravesar las distancias" (Poulet, 1964) que existen entre los diversos espacios del sistema. 
Según sea la mirada, así serán los límites que imponga a los espacios en que han de moverse los actantes. La mirada del dictador limita el mundo de la dictadura.

Algunos críticos consideran este tipo de relato como novela de espacio, a pesar del relieve del personaje que las preside, porque lo más importante de ellas es el mundo en que vive y del que es reflejo.

Poco importa el lugar concreto que se da, porque la configuración social y espacial que articulan los episodios son manifestación de la dictadura estén donde estén. Su espacio tiene que ver con el infierno dantesco del que se podría decir que es el antecedente de un cosmos que se basta a sí mismo.El dictador genera un mundo de ficción cuyos habitantes pululan en un infierno donde ejercen su pecado dominante, la ambición, que arrastra al hombre al dominio de los demás hombres.

Los micro-espacios recurrentes insisten en una isotopía semántica que asocia poder y dictadura con un entorno definido.

Se podría añadir lo que Bolnow aplica al hombre en general: "El hombre (dictador) despliega su espacio a partir del centro en que se encuentra, dentro del marco de un horizonte limitante y creador de unidad" (Bolnow, 1969, pág. 79).

En las novelas indigenistas y de explotación yankee, a veces estrechamente relacionadas, los espacios son rurales, o pequeños poblados donde los indios mantienen sus tradicionales modos de vida en contacto con la naturaleza. Tierra y animales, su fuente de vida, crean el espacio novelesco en el que se destaca la vida de pastoreo o la agricultura más elemental.

Cada vez más arrinconados en lugares alejados de la vida urbana y limitados a zonas de escaso rendimiento, tienen una economía de supervivencia, modélica para enfrentarse a la explotación de que son objeto y a las catástrofes de la naturaleza, como vemos en obras de M.A. Asturias o de de C. Alegría.

De cualquier modo, el espacio que ocupan es vivencial pues en él encuentran uno de los factores que se consideran necesarios para vivir "las formas de la convivencia humana" (Bolnow, 1969, pág. 227). Se sienten identificados con el medio que el espacio les proporciona, y siguiendo con el citado autor "el modo como el hombre se encuentra en ese lugar (se refiere al espacio vivencial) puede ser muy diferente, según que el hombre esté perdido en el azar de algún sitio o si se siente vinculado a este determinado lugar, estimándolo como adjudicado y propio. El hombre puede encontrarse en el espacio perdido o amparado, en conformidad con él o bien sintiéndose extraño".

Los indios se han adaptado a su medio vital, y esto se pone en evidencia cuando son expoliados de sus tierras por la avaricia de los hacendados o por las 
explotaciones bananeras o mineras. En ocasiones se articulan espacios diferenciados para los habitantes de la zona y para los extranjeros, de modo que se contraponen dos sistemas de vida diferentes correspondientes a culturas distintas. El espacio del explotador, siendo cómodo, desaparecerá cuando se acabe la explotación de la tierra o sus productos, o cuando éstos no sean rentables, y el de los explotados, miserable, mantiene sus tradiciones, y sobrevivirá porque sus habitantes están más adaptados al medio.

El espacio residual de los indios, donde se dan unas condiciones de vida muy precarias es mimético de su condición reducida al límite.

Los escenarios de la vida de los indios son, sin embargo, mucho más amplios que en las novelas del dictador. Los protagonistas, las reservas indias, si las podemos llamar así, se integran en la naturaleza, por eso su temática se desarrolla en comunidades que viven en la montaña, en las altiplanicies o en las orillas de un lago o un mar no dominado por el hombre blanco.

La diversidad del paisaje americano es tan rica y variada que no se puede pretender una interpretación única y asimilable de ese paisaje. Se va domesticando a medida que diversos autores de las distintas naciones lo utilizan en sus obras ayudando a significar a otros elementos de la narración. Con el tratamiento de los diversos paisajes se cumple una misión asimiladora que llegará a reducir las características comunes a ese paisaje.

Se produce poco a poco un ordenamiento de lo que en principio se presentaba como inabarcable y en cierto modo caótico, dominando al hombre, de modo que el escritor fascinado por el paisaje lo hacía protagonista.

En principio muchos autores describen ese paisaje que predomina sobre el hombre, pero después se articula con el tema de la narración y éste lo limita y lo condiciona, según vemos en las novelas indigenistas, donde se pone en relación semántica con el tema.

"La dialéctica hombre-contorno ha empezado a encontrar sus líneas adecuadas, integrando por la palabra los elementos abrumadores de una aparente desproporción. La novelística latinoamericana empieza a conocer lo que debe ser relevante en una descripción, abandonando los detalles pintorescos, diversificados, cuando no meramente naturalistas o enfatizados por un presunto panteísmo" (Aínsa, 1976, pág. 326).

El pueblo indio está tan integrado en el paisaje que apenas se destacan héroes individuales o colectivos que defienden sus "raíces". Así aparece en relatos como Hombres de maíz de M.A. Asturias, o en Todas las sangres de J.Ma. Arguedas.

La visión del paisaje se hace a través de un observador que entrecruza los hombres y su medio vital; por eso es frecuente la mimetización del hombre y 
del espacio de la que parte una mitologización que se repite de escenario en escenario, aunque éste sea diverso en cuanto los países en que se sitúan las acciones como Perú, Ecuador, México, etc.

Las novelas de espíritu revolucionario presentan como las demás un macroespacio situado en el continente americano, pero se ubican más concretamente en el país del autor o en otros donde el proceso revolucionario se manifiesta más abiertamente, e incluso sus protagonistas salen del continente y hablan desde el exilio adonde les han conducido sus actividades revolucionarias o su oposición al régimen; los personajes siguen ejerciendo su actividad desde países europeos, Francia y España preferentemente, coordinando acciones nacionales o internacionales con características de terrorismo revolucionario. Lo vemos en el Libro de Manuel de J. Cortázar. Sus protagonistas son exiliados hispanoamericanos que viven en París y montan un secuestro, en favor de su causa, que tenga resonancias universales.

Los micro-espacios se sitúan en ciudades, pueblos o incluso núcleos urbanos pequeños, nacidos al calor de la miseria o de la industria, donde se ponen en práctica las huelgas revolucionarias o se canalizan los descontentos aprovechando la facilidad de propaganda a través de creencias tradicionales que permiten encubrir o proteger a los activistas encargados de concienciar a la población descontenta y explotada.

Otras veces son las sierras o parajes inhóspitos los que acogen a un tipo de revolucionario que organiza la oposición al régimen establecido con fuerzas paramilitares, y lo combaten en guerrillas intermitentes. Se caracterizan estos espacios por la dificultad de acceso y lo intrincado de los caminos para llegar a ellos. Son reductos inaccesibles que los protegen del gobierno perseguidor.

El espacio se hace solidario del camuflaje necesario para la acción y la propaganda. En Los ojos de los enterrados se funden los temas del tirano, del indio explotado y de la revolución contra ambos. Se utilizan en ella leyendas indias relacionadas con lugares míticos concretos, como subterráneos que permiten a los cabecillas eludir la persecución de la policía y del ejército.

De este modo los espacios se asocian al tema y cobran vida aquéllos relacionados con la tortura, con las reuniones secretas y con lugares unidos a tradiciones misteriosas en relación con creencias indias o cristianas.

En estas obras, los espacios ponen de manifiesto los desplazamientos de los exiliados, las diferencias de las clases sociales, la inseguridad de ciertos lugares ocupados por los perseguidos, o los utilizados como salas de tortura o cárceles, siempre en manos de los oponentes.

Nota: La bibliografía de este estudio se incluirá en su segunda entrega, en el próximo número de Anales de Literatura Española. 


\title{
LA HEROÍNA MODERNISTA (LA MUJER FINISE- CULAR EN LAS NOVELAS DE LLANAS AGUILANIEDO)
}

\author{
José Luis CALVO CARILLA \\ Universidad de Valladolid
}

José María Llanas Aguilaniedo fue autor de tres novelas y de la más temprana sistematización de la estética de la modernidad '. Su primera obra, Del jardín del amor, dedicada "a la clarísima memoria del crítico Leopoldo Alas (Clarín)", testimonia el magisterio ejercido por el ilustre escritor asturiano, quien en El Imparcial había saludado elogiosamente la Estética de Llanas Aguilaniedo $^{2}$. La influencia sobrepasa con creces la admiración y el respeto: deriva fundamentalmente del espíritu que inspira la gran novela clariniana y, en especial, del trazado de su personaje central, Ana Ozores, cuyas fibras interiores poseen una filigrana espiritual extremadamente moderna. De ahí que María de los Angeles Pacheco sea en cierto modo una réplica de Ana Ozores, asediada también como aquélla por un medio social adverso que, no obstante, en Del jardín del amor permanece en segundo plano, implícito y difuminado.

1. José $\mathrm{M}^{\mathrm{a}}$ Llanas Aguilaniedo (Fonz, Huesca, 1875-Huesca, 1921). Sus novelas son Del jardín del amor (1902), Navegar pintoresco (1903) y Pityusa (1908). En su reedición de esta última novela, Entrambasaguas (1955) ofrece un atinado estudio y una completa biografía. Un estudio reciente es el de Calvo Carilla, 1989, págs. 99-109.

2. Llanas Aguilaniedo, 1899. Esta deferencia del asturiano no excluye la valoración de J.M. Martínez Cachero (1983). El respeto de Llanas al maestro sólo se ve matizado por la observación de "novela taquiteléutica" que hace a La Regenta en su Alma Contemporánea. Estudio de Estética. (1899) (Calvo Carilla, 1987). El concepto de "novela taquiteléutica", con el que Llanas parece querer señalar una cierta precipitación o rapidez de factura en la confección de la obra, coincide con algunos reparos de la crítica contemporánea a Clarín y con lo que el propio autor abrigaba en su fuero interno. En carta a Jacinto Octavio Picón, fechada el 3-X-1885, escribía: "El defecto en que todos están conformes, o los más, es la pesadez, a lo largo de la obra y tienen razón. Si la hubiera escrito con más tiempo y con el borrador de lo escrito ya a la vista hubiera salido más corta, pero según iba escribiendo iba mandando el original y tenía que fiarlo todo a la memoria" (En Amorós, 1981, pág. 18). 
En la creación de estos dos grandes caracteres femeninos - y sin caer en las servidumbres del autobiografismo- debe señalarse también una cierta motivación autobiográfica común. Para Leopoldo Alas (1889, pág. 128), hay que amar a los personajes, transformarse en ellos y entrar en su interior. Lo que parte de la crítica contemporánea consideró proyección del espíritu de Clarín (Beser 1968; Tintoré 1987) puede aplicarse del mismo modo a Llanas Aguilaniedo, a la luz de la atormentada vida que, casi en la flor de la juventud, desembocó en la locura. Todos los personajes que pueblan sus novelas estarán dotados de una hipersensibilidad que limita con lo irracional.

Por otra parte, ambos novelistas construyen sus obras en torno al epicentro sísmico de un personaje (Beser, 1968, pág. 248). Para Clarín (1899, pág. 128), el novelista ha de crear almas. Su contemporáneo F. Heras lo presenta en 1895 como un psicólogo de la pasión, en términos muy parecidos a los que utiliza $\mathbf{J}$. Soler (Tintoré, págs. 238 y 251-252) para saludar la aparición de La Regenta. No otra cosa es Del jardín del amor que la historia de un alma torturada, la de María de los Angeles Pacheco, sumida en un "sáfico y platónico enamoramiento". Como la de Ana Ozores, su consistencia de heroína no es sólo fisiología ni sólo espíritu: es también un conjunto de deseos vagos, de aspiraciones más o menos trascendentes, incluso de sentimientos sin nombre (Lissorgues, 1987, pág. 21). Lo esencial humano en Ana, lo que trasciende al personaje y que, desde luego, es tanto de Clarín como puede serlo de cualquier hombre, es la búsqueda de una imposible unidad del ser, la aspiración a una plenitud que rebasa los límites tanto de la materia como del espíritu. Más allá del engaño de los sentidos, más allá de los extravíos románticos, más allá de la búsqueda mística equivocada (imitar el misticismo de Santa Teresa o de San Juan de la Cruz no es misticismo, las mediaciones, en tal caso, sólo desembocan en ilusiones) lo que busca Ana es algo que trascienda su existencia sin apoyo moral o afectivo (sin hijo), solitaria, escindida. Su vida desde la infancia hasta la caída es un camino de perfección, tan imperfecto como puede serlo la vida. Camino que se pierde, por afán de absoluto, en las nebulosas de la imaginación, que va, por desesperación, hacia las suertes de la locura...(Lissorgues, pág. 21).

Este diagnóstico puede servir para caracterizar a ambas heroínas. Las separa, en cambio, la mayor liberación de María de los Angeles Pacheco respecto a los postulados naturalistas. Si los ensueños y accesos místicos de Ana están en estrecha relación con la debilidad de su cuerpo y su exaltación interior obedece a los impulsos de un espíritu que, debido a su deficiente educación, no está bien dominado por la conciencia, en el caso de María de los Angeles se derivan de su condición de mujer superior, "hipermoderna", refinada espiritualmente en extremo. El punto de conflicto entre ambas lo señala de nuevo Lissorgues al hacer referencia a las concepciones un tanto puritanas del creador de La Regenta, para quien la conciencia debía ejercer siempre un papel 
vigilante, ya que, sin este manto protector, se llega al relajamiento del pensamiento y la voluntad, lo que lleva a Ana a una religión de los sentidos. E] sensualismo religioso (y su consecuencia, el amoroso) son, para Alas, en el mejor de los casos, una impureza, algo demasiado ligado a la "quintaesencia" de los sentidos. Por otra parte, este sentir vuelto del todo sobre sí mismo es un sentir egoísta - mejor egotista- que puede hacer caer a quien lo experimenta en la atrevida impresión de que es un ser superior (Lissorgues, pág. 26).

Parecidas acusaciones habría podido lanzar el viejo maestro sobre la figura de María de los Angeles, heroína de una nueva época, aunque no tan distante de la factura de Ana, ya que la modernidad de esta última — puesta de relieve en varios estudios (Valis, 1983; Gullón, 1983; Sánchez, 1987)—, estriba en que sufre los condicionamientos de la novela naturalista, pero, a la vez, se escapa de ellos. Quizá porque Clarín concebía la novela como una "anatomía espiritual" que la hacía superior al teatro (Alas, 1892, pág. 297), había concedido a su personaje esa libertad que luego hará suya plenamente María de los Angeles Pacheco.

María de los Angeles encarna una de la modalidades de la heroína modernista. Si el héroe, que recoge la herencia romántica "genio", "mártir", "sacerdote" o "visionario" sin perder su dimensión aristocrática se enfrenta al mundo y pugna por definirse a sí mismo y concederse un programa de vida (Blasco Pascual, 1986, págs. 389-402), su correlato femenino también se nutre de perdurables esencias románticas. Su evolución a través del naturalismo - escuela a la que le interesa más lo fisiológico que lo psicológico-generará un tipo de mujer patológico y anómalo. Madame Bovary, Ana Karenina, Effi Briest y Ana Ozores, heroínas estudiadas por Biruté Ciplijauskaité, "sufren de los nervios": un sufrimiento que adquiere las proporciones de tristeza e incluso de locura al final (Ciplijauskaité, 1984, pág. 46). Carencias básicas que proceden en especial del "bovarysmo" más el "ozorismo" son la necesidad de afecto, dado y recibido y, en definitiva, su frustración como mujer (Mora, 1989, págs. 88 y ss.).

Esta herencia naturalista se prolongará en el fin de siglo favorecida por los avances científicos y la moda de la sociología criminal. Lily Litvak ha estudiado, a propósito de la contribución azoriniana, la influencia de estas corrientes en la creación literaria, desde novelas como La piedra angular de Emilia Pardo Bazán a La lucha por la vida de Baroja. La sociología criminal, supone, en cierto modo, reavivar los presupuestos naturalistas en cuanto a herencia y condicionamiento del medio y de la fisiología, que ayudan a explicar los casos degenerados o patológicos. No es ajeno a estos planteamiento Max Nordau, con sus aplicaciones al arte y a la literatura. Desde este "cientifismo" de las anomalías en las conductas no era difícil pasar al estudio de las enfermedades 
del alma o de la voluntad, punto en que confluyen las ciencias experimentales con las tendencias filosóficas antipositivistas ${ }^{3}$.

El fin de siglo presenta en la literatura y en las artes plásticas socorridos estereotipos de belleza femenina. Es la mujer ideal que se viste a la moda de París, con amplias ropas de tafetán o muselina, de cintura ajustada y guantes hasta el codo; que cubre su cabeza con grandes sombreros decorados con floridos jardines o variopintas cornucopias. El modern style destaca en ellas una nueva línea que realza su silueta, la amplía en evocadoras curvas y, en caso de necesidad, llega a enmendarla. Es la mujer ideal, encantadora, frívola, mundana, la musa de poetas, fotógrafos o príncipes rusos... (Waltzer, 1975, pág.91).

Pero este modelo de belleza exterior coexiste con otro, cuyos encantos los proporciona la belleza espiritual de un alma inquietante, perversa, atormentada y misteriosa. Villiers de l'Isle Adam se había planteado la forma de complementar estas dos mujeres ideales. La Eva futura, surgida del laboratorio del "brujo" Thomas A. Edison constituye un revolucionario experimento de dotar de alma a una Alicia Clary afeada interiormente por un espíritu vulgar. La Hadaly que se reencarna en su espléndido cuerpo resulta una efímera ilusión que, pese a los desesperados esfuerzos de Lord Ewald, perece en el naufragio de todos los empeños irrealizables (De l'Isle Adam, 1885).

Los dos ideales de feminidad atraviesan el fin de siglo, pero es esa desconcertante complejidad psicológica la que ejerce un mayor poder de seducción. A menudo desdoblada en virgen y prostituta, en la Eva y en la María de los prerrafaelitas, la mujer es objeto de una atención cada vez más constante en la literatura, y en particular en las novelas, que, con frecuencia, tienen como título un nombre de mujer (Cerdá i Surroca, 1981).

En este protagonismo tiene mucho que ver los movimientos finiseculares de liberación de la mujer. En este sentido, la atención prestada por la Iglesia católica, que en 1854 proclama el dogma de la Inmaculada Concepción, es todo un síntoma del signo de los tiempos (Roldán Ruiz y Valenzuela Jiménez, 1987, pág. 442; Freixa, 1984, págs. 119-138), cuando no un intento de apropiación religiosa de la naciente "cuestión de la mujer". Aunque en España tienen lugar

3. Fundada por el médico italiano Cesare Lombroso, la sociología criminal tuvo una gran repercusión en Europa durante el último cuarto del siglo XIX. Sus aportaciones, destinadas inicialmente a estudiar los comportamientos marginales de la sociedad, tuvieron, en discípulos como Ferri, una aplicación al derecho penal, a la medicina, a los sistemas penitenciarios, a la sociología, a la psicología, etc. y, en general, afectó, en mayor o en menor medida, a todos los intelectuales del fin de siglo, con actitudes de aceptación o de rechazo fuertemente encontradas. Como estudia L. Litvak (1990, págs. 129-154), Llanas Aguilaniedo se cuenta entre los muchos seguidores de Lombroso en España, con estudios específicos como La mala vida en Madrid. Estudio psicofisiológico o su traducción de La mala vida en Roma. Sobre la influencia de Max Nordau, frecuentemente asociada a la de Lombroso y su relación con la estética de Llanas se han ocupado en fechas recientes J.C. Mainer, 1989 y J.L. Calvo Carilla, 1991. 
con un cierto retraso histórico, escritoras como Concepción Arenal, Emilia Pardo Bazán o Carmen de Burgos denuncian desde distintas posiciones la postergación social y exigen igualdad de derechos con el hombre. Tampoco son ajenos a estas corrientes los principios de la filosofía krausista, respetuosa con su dignidad e impulsora de la coeducación y preparación para otros oficios diferentes de la enseñanza. En estos momentos cruciales para la historia del feminismo, Llanas — que llegó a simpatizar con el krausismo, como lo demuestran sus colaboraciones en la Revista de la Institución Libre de Enseñanza (Llanas Aguilaniedo, 1902b y 1903b; Esteban Mateo, 1978)—, es sensible a algunos de sus planteamientos. Como concluye su artículo "La Eva futura":

la mujer por su parte mirará cada vez con menos simpatía a un orgulloso - cuando no un tirano- que aprovecha cuantas ocasiones se le presentan para humillarla, tratándola desdeñosamente desde lo alto de su torre dorada, y en el cual tampoco hallará interés, pues ni el talento y erudición, ni otras prerrogativas de la masculina raza, satisfarán jamás a la mujer como un poco del sentimiento de la vida que ella perpetúa y conserva. (Llanas Aguilaniedo, 1901, pág. 7)

María de los Angeles Pacheco ejemplifica este modelo finisecular de mujer libre e intelectualmente superior. En su espíritu brillan los destellos del superhombre nietzscheano. Si bien las ideas de Nietzsche sobre la emancipación de la mujer ilustran la actitud negativa general en su tiempo, con poco esfuerzo podrían espigarse - por ejemplo, del capítulo VII del El viajero y su sombra, aunque con reservas relativas a las capacidades y complejidad del carácter femenino ${ }^{4}$-, opiniones más favorables. Con todo, no es difícil que, en su consideración genérica, la bandera del "hombre superior" arrope también a la mujer, a la que el propio Nietzsche considera como un cerebro lúcido, complejo y ansioso de superación. La recepción de Nietzsche en España —que Gonzalo Sobejano ha documentado a partir de 1893 - confluye con la de otros grandes maestros del momento (Maeterlink, Ibsen, etc). Por muy diferentes que sean sus creaciones, apunta en ellos como rasgo coincidente el trazado de unos caracteres que sobresalen de la vulgaridad colectiva. La Nora ibseniana es una de las máximas realizaciones de este aristocratismo irrepetible, encarnado con valor añadido y ejemplar en un personaje femenino.

Alma contemporánea. Estudio de estética (1989) es uno de los testimonios más tempranos de la presencia de Nietzsche en España (Sobejano, 1967, págs. 65-66). La lectura que del autor de Así habló Zaratustra realiza el oscense sigue en líneas generales la mediación hermenéutica que Joan Maragall y Pompeyo

4. En Nietzsche (1985, págs. 2081-2096). Del testimonio de Leopoldo Alas (1899) - cuyas ideas al respecto, dentro de su comprensiva moderación, pretenden quitar hierro frente a los detractores del alemán-, se desprende, no obstante, que las ideas de Nietzsche sobre la mujer fueron interpretadas en la época como totalmente negativas. 
Gener habían realizado en sus fragmentarias traducciones de Així va parlar Zarathustra. Frente a los "castellanos", que pusieron el énfasis en el disolvente anarquismo del filósofo, los catalanes se fijan en el "hombre superior", aristócrata de alma y de cuerpo frente a los débiles y decadentes (Sobejano, 1967, págs. 38-40).

Profundamente nietzscheana es María de los Angeles Pacheco. El medio, lejos de determinar su comportamiento, es solamente un degradado marco de contraste frente al que surge el torrente emocional al margen de normas y convenciones. Su diario es la crónica de un amor físico e intelectual que, de acuerdo con Felipe Trigo, si se desarrollase en libertad podría llegar a una Armonía completa ${ }^{5}$.

Es el aristocratismo de un ser superior y de sus selectas manifestaciones espirituales que cobra vida literaria en los personajes dannunzianos.

Gabrielle D'Annunzio goza de gran popularidad en la España finisecular. Todos los testimonios recogidos por Sobejano reflejan la consideración del italiano como discípulo y difusor de Nietzsche, ya que su esteticismo se interpretaba como la versión artística de la ecuación nietzscheana vida-fuerza ${ }^{6}$. Como ha estudiado Bugliani, la presencia de D'Annunzio es muy compleja y difusa. Entre sus diversas manifestaciones, que van desde lo superficial a lo satánico, el modernismo peninsular muestra predilección por un esteticismo cerebral, un refinamiento en el lenguaje y un aristocrático desprecio por todos los aspectos de la vida corriente, por los principios y los ideales tradicionales ? El refinamiento, la neurosis, la voluptuosidad espiritual de los seres que pueblan obras como la influyente Città morta contaminan las páginas de muchas novelas contemporáneas.

5. Al menos esa es la tesis que excepcionalmente se cumple en su novela Las Evas del Paraíso (1910). La cosmovisión novelesca del pacense Felipe Trigo (1864-1916) -que debió coincidir en alguna ocasión con Llanas, ya que era médico militar-, tiene algunos puntos en común con éste en cuanto al tratamiento del amor intelectual y sensual, místico y humano, aunque sus personajes de mayor interés sean los masculinos. Expuso sus ideas en la conferencia de $1907 \mathrm{El}$ amor en la vida y en los libros, ampliada y editada más tarde como El amor en la Vida y en los libros. Mi ética y mi estética. De este autor se ocupan L. Litvak (1979) y A. Martínez San Martín (1983).

6. Sobejano (1967, pág. 214) recoge de testimonios contemporáneos la consideración de D'Annunzio como intermediario entre Nietzsche y Valle Inclán y la interpretación de su esteticismo como versión artística de la ecuación nietzscheana vida-fuerza.

7. Bugliani (1976, pág. 11) escribe a este respecto: "L'umanitarismo democratico viene sostituito con un dividualismo aristocraticamente autonomo che nella contemplazione dei misteri della vita e degli enigmi del mondo spesso assume aspetti mistici la cui comprensione e privilegio esclusivo di pochi individui seletti. Da questo modo di vedere la realtà della vita scompare l'assoggettamento al tempo fisico presente, e sorge una nuova poetica formata con un tempo psichico e questo a sua volta composto di elementi puramente musicali che servono di complemento per la conoscenza dell'anima". 
María de los Angeles es de las mujeres que, como la Madame Roche de $L a$ ciudad en la niebla, dividen a la humanidad en dos partes: la constituida por bellas señoras intelectuales y hombres de talento y la de la gente vulgar y ordinaria.

Quizás sea en Pityusa (Llanas Aguilaniedo, 1908) donde se dan cita todas las características del italiano: el paganismo de una naturaleza salvaje, la posesión y el dominio hasta el sadismo o una moral que abarca desde la inocencia hasta la perversión. A la altura de 1908, D'Annunzio se ha convertido en una obsesión para los personajes de Llanas Aguilaniedo, hasta el punto de que hace pensar a Pityusa:

\section{¡Cómo y dónde se hallaría D’Annunzio!}

Sin duda viviendo la existencia de luz que reflejaba en las pomposas páginas. Antiguas ciudades, radiantes aún con la ceniza de riquezas pretéritas; monumentos, tesoros de arte acumulados por la labor de las generaciones; cuanto bello y heroico había entrevisto al estímulo de aquella genialidad fastuosa y desbordante, volaba en su cerebro, inflamándole las sienes, haciendo correr y serpear por sus venas fuego líquido.

¡Oh, sí! Era aquélla su musa, su inspiración, el genio amigo. Convencería a su hombre, escribiría ella también; la incomparable esencia hormigueaba y se difundía bajo su frente. ¡A cualquier precio sentirla, sufrir y gozar con sus amores, quemarse en su llama con la sublime inspiración del que juega a conciencia su vida en cada instante! (Llanas Aguilaniedo, 1908, pág. 260).

Pero ya en Del jardín del amor: las dos citas danunzianas demuestran sin lugar a dudas la admiración de Llanas hacia la complejidad espiritual de las criaturas del escritor italiano, lo que se materializará en el sensible y voluptuoso perfil anímico de María de los Angeles Pacheco.

Y si D’Annunzio es uno de los artífices de la ampliación de los confines del alma, diversas incitaciones finiseculares confluyen en la exploración de las fronteras racionales de los personajes. Un arte de sugerencias, como el modernista, que fluye del sentimiento y de la emoción y que está orientado a ser aprehendido por la intuición, era un arte que se oponía a la razón y que abría un resquicio para que aflorara el subconsciente del autor y para que se conmocionara el subconsciente del lector. Si bien los trabajos de Freud no debieron de ser conocidos todavía en España cuando Llanas Aguilaniedo escribía Del jardín del amor, existía una corriente con precedentes autóctonos en este tipo de indagaciones, representada por críticos y novelistas como Urbano González Serrano, Eduardo Gómez de Baquero o el mismo Pío Baroja (Celma Valero, 1989, pág. 143 y ss.). De su progresiva incorporación a la creación novelesca pueden encontrarse ejemplos en Del jardín del amor, Camino de perfección (Baroja, 1902) o en Amor y pedagogía (Unamuno, 1902). 
En el fondo, estos escarceos responden a algo que está en el ambiente finisecular y que obedece en última instancia, —como ha señalado Tadié-, a las pretensiones científicas de la psicología, cuyo influjo irá modulando la dislocación exterior e interior del héroe, ya que ella constituye el horizonte ideológico de los novelistas y nutre el aire que respiran. Cuando, según Taine y los ingleses el yo no es más que una serie de estados de conciencia, cuando la Psicologie de l'inconscient de Hartmann se ha traducido (al francés, en 1877), cuando Ribot estudia sucesivamente las enfermedades de la memoria, de la voluntad, de la personalidad, se observa cómo se constituye una nueva cultura, que será común a Freud, a Bourget, a Proust, en el que se encuentran las etapas de la degradación del positivismo (Tadié, 1978, pág. 14).

De todos estos estímulos vivificadores surge esta mujer excepcional de Llanas Aguilaniedo. Como más tarde Pityusa, María de los Angeles Pacheco se convierte en una de las heroínas más emblemáticas del fin de siglo. Puesta en pie inicialmente con la convicción humana que puede proporcionar un caso clínico, su creador hace suyas las aspiraciones de J.K. Huysmans en boca de su personaje Durtal, cuando decía que "es necesario conservar la veracidad del documento, la precisión del detalle, el lenguaje fastuoso y nervioso del realismo; pero también es necesario hacerse buzo de almas y no pretender explicar el misterio por las enfermedades de los sentidos. Si se pudiera, la novela debería dividirse por sí sola en dos partes, la del alma y la del cuerpo, soldadas o más bien confundidas como lo están en la vida, y ocuparse de sus reactivos, de sus conflictos y de su unión. En una palabra, sería necesario seguir la ancha vía abierta tan profundamente por Zola; pero también se necesitaría trazar en el aire un camino paralelo, otra ruta, uniendo las dos, creando, finalmente, un naturalismo espiritualista. ¡Eso sí que sería lo hermoso, lo completo, lo fuerte!". Para concluir que "por el momento, no lo hace nadie. A lo más, podría citarse, como aproximándose a ese concepto a Dostoievski” (Huysmans, 1891, pág. 15).

Aspiración que se materializa en María de los Angeles, sensualidad y espíritu, grandioso estudio de una pasión encarnada en un ser escogido que se independiza de su creador $y$, al margen de restricciones narrativas o morales, vive y se muestra en su jardín con la franqueza, el ardor y aun la altivez de todo ser humano que siente vocación para ello y ocupa en la sociedad un puesto libremente elegido. Del mismo modo que la cortesana Afrodita, tendrá la ambición de elevarse al más alto lugar y ni siquiera imaginará que su vida tenga necesidad de excusa o de misterio (Louÿs, 1885, pág. 27).

En alguna ocasión han sido relacionadas las criaturas de Llanas con las de este raro escritor francés (González Blanco, 1909, pág. 1000), con quien sin duda comulga en el erotismo y la voluptuosidad que destilan sus novelas y en el 
relieve que alcanzan sus heroínas. (Sin olvidar las Canciones de Bilitis, que conforman ya "una a modo de novela lírica en cuyo curso se desarrolla y se exalta el amor lesbiano más poderoso y vehemente que el amor normal, la voluptuosidad entre mujeres que glorificó Safo y que en nuestros tiempos han cantado Baudelaire, Verlaine y varias poetisas desfallecientes bajo la crueldad encantadora de su pasión anormal'-Blasco Ibáñez, en Louÿs, 1885, pág. 15). Pero los paralelismos terminan allí donde emerge la complejidad de la heroína de Llanas, superior al pagano refinamiento de Afrodita o la enigmática perversión, casi rayana en el sadismo de la sevillana Conchita (Louÿs, 1898), carentes ambas de la dimensión espiritual que caracteriza a María de los Angeles Pacheco. Dicha complejidad y la intensidad con que experimenta sus emociones, a expensas de cualquier intento de novelación decimonónica, confieren a esta obra la plenitud en la plasmación de la anatomía de un alma. Pierre Louÿs enriquecido con las cargas de profundidad de D'Annunzio. Porque $\mathrm{M}^{\mathrm{a}}$ de los Angeles es, como las criaturas dannunzianas, mítica habitante de una ciudad muerta, única superviviente de un paraíso cuyas inagotables bellezas no tienen otro contemplador que quien las cultiva.

\section{BIBLIOGRAFIA}

ALAS, Leopoldo. 1889. Mezclilla. Madrid, Enrique Rubiños.

-. 1899. "Nietzsche y las mujeres". El Español, 6 y 7-IX.

En RAMOS GASCÓN, A. (Ed.). Clarín. Obra olvidada. Madrid, Júcar, 1973, págs. 199-209.

-. 1892. Ensayos y Revistas. Madrid, M. Fernández y Lasenta.

AMORÓS, Andrés. 1981. "Doce cartas inéditas de Clarín a Jacinto Octavio Picón". Los Cuadernos del Norte, II, 7, págs. 8-20.

BAROJA, Pío. 1902. Camino de perfección. Reedición: Madrid, Caro Raggio, 1974.

BESER, Sergio. 1968. Leopoldo Alas, crítico literario. Madrid, Gredos.

BLASCO PASCUAL, Francisco Javier. 1986. "Algunas notas para el estudio de la presencia de Gracián en el 'héroe' modernista". Actas de la I Reunión de filólogos aragoneses. Zaragoza, Institución Fernando el Católico, págs. 389-402.

BUGLIANI, Americo. 1976. La presenza di D'Annunzio in Valle-Inclán, Milano, Cisalpino-Goliardica.

CALVO CARILLA, José Luis. 1987. "Clarín y Aragón (Dos notas bibliográficas)". En Hitos y Mitos de La Regenta. Monografías de Los Cuadernos del Norte, 4, págs. 132-133.

—. 1989. "La solitaria aventura de Llanas Aguilaniedo". En El modernismo literario en Aragón. Zaragoza, Institución Fernando el Católico, págs. 99-109.

—. 1991. "Alma contemporánea: una estética de la modernidad". Castilla, 15, págs. 33-51. 


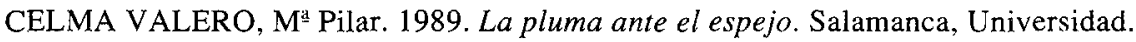
CERDÁ I SURROCA, Mํa Angela. 1981. Els pre-rafaelites a Catalunya. Una literatura $i$ uns simbols. Barcelona, Curial.

CIPLIJAUSKAITÉ, Biruté. 1984. La mujer insatisfecha. El adulterio en la novela realista. Barcelona, Edhasa.

ENTRAMBASAGUAS, Joaquín. 1955. Las mejores novelas contemporáneas. Barcelona, Planeta, vol. III.

ESTEBAN MATEO, Luis. 1978. Boletín de la Institución Libre de Enseñanza. Nómina Bibliográfica (1877-1936). Valencia, Universidad.

FREIXA SERRA, Mireia. 1984. "La imagen de la mujer en el modernismo catalán". La imagen de la mujer en el arte español. Madrid, Universidad Autónoma, págs. 119-138.

GONZÁLEZ BLANCO, Andrés, 1909. Historia de la novela en España desde el Romanticismo a nuestros días. Madrid, Sáenz de Jubera Hnos. Editores.

HERAS, Fernando. 1895. "Don Leopoldo Alas Clarín". La Vanguardia, 12-VI. En TINTORÉ, M̃ José. La Regenta de Clarín y la crítica de su tiempo. Barcelona, Lumen, 1987, págs. 232-241.

HUYSMANS, Joris-Karl. 1891. Là-bas. Traducción de G. GOMEZ DE LA MATA: Allá lejos. Barcelona, Bruguera, 1986.

LISSORGUES, Yvan. 1987. "Ética, religión y sentido de lo humano en La Regenta". Hitos y mitos de La Regenta, cit., págs. 20-31.

LITVAK, Lily. 1979. Erotismo fin de siglo. Barcelona, Bosch.

- 1990. "La sociología criminal y su influencia en los escritores españoles de fin de siglo". En España 1900. Modernismo, anarquismo y fin de siglo. Madrid, Anthropos, págs. 129-154.

LOUYS, Piere. 1885. Aphrodite. Versión española de J. MARTINEZ CLAVEL: Afrodita. Prólogo de Vicente BLASCO IBAÑEZ, Valencia, Prometeo, s.a.

- 1898. La Femme et le Pantin. Traducción de Emiliano RAMIREZ ANGEL: La mujer y el muñeco. Prólogo de V. BLASCO IBAÑEZ, Valencia, Prometeo, s.a.

LLANAS AGUILANIEDO, José Ma. 1989. Alma Contemporánea. Estudio de Estétića. Huesca, Tip. de Leandro Pérez.

-. 1901. "La Eva futura". Juventud, 1, pág. 7.

- 1902a. Del jardín del amor. Madrid, Libr. de Fernando Fe - Libr. de Victoriano Suárez.

—. 1902b. "El obrero y la taberna". Boletín de la Institución Libre de Enseñanza, XXVII, págs. 115-122.

- 1903a. Navegar pintoresco. Madrid, Libr. de Fernando Fe - Libr. de Victoriano Suárez.

—.1903b. "Trabajo y Zola", Boletín de la Institución Libre de Enseñanza, XXVIII, págs. 123-128.

- 1908. Pityusa. Madrid, Fernando Fe. 
MAINER, José-Carlos. 1989. "La crisis de fin de siglo a la luz del "emotivismo": sobre Alma Contemporánea (1899) de Llanas Aguilaniedo". En Letras aragonesas. Zaragoza, Oroel, págs. 97-115.

MARTÍNEZ CACHERO, José M". 1983. "Sobre la actitud antimodernista del crítico Clarín”. Anales de Literatura Española, 2, págs. 383-398.

MARTÍNEZ SAN MARTÍN, Antonio. 1983. La narrativa de Felipe Trigo. Madrid, C.S.I.C.

MORA, Magdalena. 1989. "La construcción de la identidad en el personaje novelístico. Madame Bovary (1837) y La Regenta (1884-1885)". En Teoría del personaje (Compilación de Carlos CASTILLA DEL PINO). Madrid, Alianza Universidad, págs. 75-97.

NIETZSCHE, Frederich. 1985. Obras Completas. Traducción de E. EIDELSTEIN, M.A. GARRIDO Y C. PALAZÓN. Barcelona, Teorema, 4 vols.

ROLDÁN RUIZ, Amalia; VALENZUELA JIMÉNEZ, Rafaela. 1987. "La mujer finisecular en la obra de Manuel Reina". Actas del Congreso Internacional sobre el modernismo español e hispanoamericano. Ed. de Guillermo CARNERO. Córdoba, Diputación, págs. 441-445.

SANCHEZ, Elizabeth. 1987. "Más allá del paradigma realista: estratagemas subversivas en La Regenta y Madame Bovary". Hitos y Mitos de La Regenta, cit., págs. 63-67.

SOBEJANO, Gonzalo. 1967. Nietzsche en España. Madrid, Gredos.

SOLER, Josep. 1895. "Clarín”, La Publicidad, 15-VI. (En TINTORE, María José., op. cit., págs. 242-252).

TADIE, Jean-Yves. 1978. Le récit lyrique. Paris, Presses Universitaires de France.

TINTORE, María José. 1987. La Regenta de Clarín y la crítica de su tiempo. Barcelona, Lumen.

TRIGO, Felipe. 1910. La Evas del Paraíso. Madrid, Renacimiento.

-.1920. El amor en la vida y en los libros. Mi ética y mi estética, Madrid, Renacimiento. $\left(5^{\mathrm{a}}\right)$.

UNAMUNO, Miguel de. 1902. Amor y pedagogía. Reedición: Madrid, Alianza, 1989.

VALIS, Noël. 1983. “Order and Meaning in Clarín's La Regenta”, Novel, 16, págs. 246-258.

VILLIERS de l'ISLE ADAM, Jean-Marie. 1885. La Eva Futura. Trad. de Mauricio BACARISSE. Madrid, Valdemar, 1988.

WALTZER, Pierre-Olivier. 1975. Le XXe. siècle, I 1896-1920. Paris, Arthaud. 
. 


\title{
LAS EXEQUIAS DE LA LENGUA CASTELLANA DE JUAN PABLO FORNER, "SÁTIRA MENIPEA"
}

\author{
Marta CRISTINA CARBONELL \\ Universidad de Barcelona
}

En 1871, Leopoldo Augusto de Cueto editaba por vez primera, en el tomo LXIII de la Biblioteca de Autores Españoles, las Exequias de la Lengua Castellana, "escrito singular" con el que cerraba la antología de textos fornerianos integrantes de su compilación de Poetas líricos del siglo XVIII, en atención a las "varias composiciones poéticas que contiene esta obra inédita de Forner [...], su mérito intrínseco y su peculiar carácter" . "Peculiar carácter" que abordaría, unos años después, don Marcelino Menéndez Pelayo cuando, en su Historia de las ideas estéticas en España, y tras reivindicar la edición en solitario de ésta que considera "la más excelente y madura" de las obras de Forner, señalaba, aludiendo a sus particulares rasgos formales:

En las Exequias, que el autor llamó sátira menipea por ir entremezclada de prosa y versos, siendo en realidad una ficción alegórica del género de la República Literaria o de la Derrota de los pedantes, inferior a ellas en amenidad y gracejo, pero muy superior en alteza y trascendencia de miras, como obra no de un mero humanista, sino de un pensador original y penetrante, Forner recorre con erudición inmensa y crítica, franca y resuelta, todo el campo de nuestra literatura [...] derramando de paso copiosa doctrina sobre todos los géneros literarios (Menéndez Pelayo, 1974, I, págs. 1311-1312).

El rótulo explícito de sátira menipea, cuando no sátira varroniana, acompaña efectivamente al título de la obra en la práctica totalidad de los

1. Cueto, 1952, pág. 378. El texto de las Exequias editado por Cueto es el que ha servido de base para las ediciones modernas de la obra, entre ellas, la de Pedro Sainz Rodríguez en "Clásicos Castellanos". Conviene, sin embargo, tener en cuenta los problemas que plantea dicho texto, abordados por Lopez, 1976, págs. 586-590. 
manuscritos de ella conocidos ${ }^{2}$, llamando así la atención sobre unas señas de identidad genéricas en las que Forner insistirá por dos veces a lo largo del texto: en la socarrona "Noticia del Licenciado Pablo Ignocausto" que abre las Exequias, Juan Pablo Forner, arropado en su doble disfraz de "editor" de los papeles del "Licenciado" — supuesto autor de la obra-, lleva a cabo una auténtica declaración de principios éticos y estéticos al socaire de la ironía y el humor grosero, y se complace en presentar la menipea como digno producto del desatinado juicio del estrafalario Ignocausto, exponiendo todos aquellos argumentos que le aseguren el éxito que merece entre los lectores "de destemplado gusto":

Por lo que toca a la invención de la fábula, el mismo Ignocausto dice en el final de ella lo que basta para conocer su total demérito. Llamóla Sátira Menipea, porque dice que en la Grecia hubo un tal Menipo, primer padre de estas invenciones monstruosas, que mezclan la prosa con el verso, y emplean el verso y la prosa en morder y zumbarse de las majaderías humanas. Que un pedante del Lacio, llamado Marco Varrón, íntimo amigo del charlatán y superficial Tulio, había escrito también mucho en este estilo, y con esto damos a entender lo bastante del corto mérito que debe tener una obra hecha por patrones tan desatinados ${ }^{3}$.

Para insistir de nuevo en los últimos compases de la obra, cerrando las Exequias con unas consideraciones relativas al género de la composición que quieren justificar las particularidades y licencias de ésta que denomina "invención quimérica", donde "el asunto principal aparece allá casi al final de ella, anegado en una multitud de episodios que poco o nada tienen que ver con él":

... en estas obras, ¿quién os ha de pedir los rigores y puntualidades de una fábula épica o dramática? Estos escritos, que se llaman satiricones, corren y saltan libremente en campo ilimitado, y en la pequeñez de los sermones del mismo Horacio hallaréis frecuentes ejemplos del genio licencioso y lasciviante, si es lícito decirlo así, de esta casta de obras. La sátira es retozona, y no gusta de reducirse a la clausura de un círculo. Luciano, Apuleyo, Capella y sus imitadores os darán cuanta metralla necesitéis para rociar a los reparones (pág. 210).

El texto de las Exequias discurre, de este modo, entre dos asertos reivindicativos de una muy determinada tradición del género que buscan, de un

2. Véase al respecto, Lopez, 1976, pág. 586. Unicamente el Ms. 6795 de la Biblioteca Nacional presenta el rótulo "Sátia Varroniana", mientras que el Ms. 122 de la Real Academia, que responde a la primera redacción, inacabada, de là obra, y de gran importancia para comprender el designio inicial de Forner al concebirla y esbozarla, en un contexto bastante alejado del que presidirá su redacción definitiva, sólo comprende el título de la obra, sin subtitular. Esperamos póder desarrollar estas cuestiones en una próxima edición crítica de las Exequias de la Lengua Castellana. página.

3. Citamos por J.P. FORNER, 1967. En adelante, señalaremos únicamente el número de 
lado, ilustrar su prestigio, al amparo de tan antigua tradición, y de otro, justificar sus peculiaridades formales, apelando a la naturaleza y disposición, refrendada por su cultivo en los clásicos. La insistencia de Forner en este sentido, que distingue a la obra en el conjunto de su producción crítica y satírica ${ }^{4}$, conduce necesariamente a plantear el interés forneriano por la sátira menipea en tanto que molde estructural sobre el que erigir el magno ejercicio de crítica que son las Exequias de la Lengua Castellana, proyecto que Forner concibe, pule y corona a lo largo de los diez años más fructíferos de su vida ${ }^{5}$. François Lopez abordó esta cuestión en su excelente Juan Pablo Forner et la crise de la conscience espagnole au XVIIIe siècle, donde, en el apéndice que dedica a las Exequias planteaba la necesidad de considerar las razones que movieran a Forner a inclinarse por el molde de la menipea, desechando, por ejemplo, la sátira en verso. Lo valioso de su aportación en este sentido, y la penetración de sus juicios, que han marcado una reconocida inflexión en los estudios fornerianos, permite, no obstante, matizar y ampliar algunos de sus presupuestos, que siguen siendo punto de partida indispensable para cualquier análisis de este auténtico "testamento literario" donde vienen a converger los hilos de la producción toda de Juan Pablo Forner.

Preguntándose por aquellos rasgos que definen la naturaleza de la sátira menipea más allá de la mezcla de prosa y verso y la flexibilidad de su forma, explícitamente señalados por Forner, el profesor Lopez se remitía a las páginas que a ella dedica Mijail B. Batjín en sus Problemas de la poética de Dostoievski, donde hallaba una brillante exposición de la teoría del género desde sus orígenes, y una minuciosa descripción de sus características y vicisitudes a lo largo de la historia, iluminando la filiación de las Exequias a través de las numerosas coincidencias que presentan con los rasgos enumerados por Batjín (Lopez, 1976, págs. 594-598), cuya caracterización de la sátira menipea es,

4. En más de una ocasión, y siempre a posteriori, a raíz de alguna polémica levantada por ellos, quiso Forner legitimar sus textos satíricos emparentándolos con las "críticas y sátiras urbanas" de Boileau o Pascal, e incluso, como es el caso de Los Gramáticos, con el Quijote ; en ninguna ocasión, sin embargo, reivindicó explícitamente, en el texto mismo de la obra, su propia naturaleza al amparo de tan rancia tradición clásica. En cualquier caso, sus palabras venían a adelantarse a las probables críticas que pudiera recibir en nombre de la "unidad de las partes" horaciana, que tantas veces esgrimiera él mismo frente a las obras ajenas, y que le había sido recordada airadamente por Tomás de Iriarte ante sus Gramáticos.

5. No podemos abordar aquí la problemática textual de las Exequias, pero debe tenerse en cuenta que fueron con toda seguridad concebidas y esbozadas contemporáneamente al desarrollo del pleito sostenido por Forner con los Iriarte a raíz del intento de publicación de Los Gramáticos, luego a la altura de 1783-84, y que fueron reelaboradas y retocadas posteriormente a lo largo de la década, si bien se conformaron como texto completo hacia 1787-88, en el desarrollo de la polémica suscitada por su Oración Apologética. Los cambios que sufrieran en estos años, según se desprende del cotejo de manuscritos, son indicativos del distinto talante que moviera a Forner en el momento de su composición respecto del que presidirá su redacción definitiva, muy marcada por dicha polémica, si bien los últimos retoques del texto corresponden ya a los inicios de la década del 90 . 
como el propio autor advierte, "descriptiva" en lo que se refiere a sus particularidades genéricas (Batjín, 1988, pág. 170), y se orienta a situarla y valorarla en el ámbito del carnaval ${ }^{6}$, donde halla la clave de la unificación de los elementos variadísimos y heterogéneos que la conforman - diálogo fỉlosófico, aventura, fantasía, naturalismo bajo, utopía...- en un todo orgánico de género, cuya integración interna subraya repetidamente ${ }^{7}$. Es la percepción carnavalesca del mundo, según Batjín, lo que permite la singular plasmación del sustancial dialoguismo filosófico de la menipea: "la unión de la idea con la aventura en forma de imagen artística" (Batjín, 1988, pág. 189), la traslación de las "últimas cuestiones filosóficas" al plano de lo concreto y sensorial, de forma que la sátira menipea, género proteico y multiforme emparentado con el diálogo socrático, pero libre de sus exigencias de verosimilitud, y más proclive a potenciar la risa y el contraste, halla su particularidad más importante en el hecho de que

en ella, la fantasía más audaz e irrefenable y la aventura, se motivan, se justifican y se consagran interiormente por el propósito netamente filosófico de crear situaciones excepcionales para provocar y poner a prueba la idea filosófica, la palabra y la verdad, plasmada en la imagen del sabio buscador de esta verdad [...] con este fin los héroes de la sátira menipea suben hasta los cielos, descienden a los infiernos, viajan por países fantásticos y desconocidos, caen en situaciones excepcionales [...] pero siempre la aventura se somete a la función netamente ideológica de provocar y poner a prueba la verdad" (Batjín, 1988, págs. 161-162).

Este "universalismo filosófico" de la sátira menipea articula asimismo la caracterización que de ella realizara Northrop Frye en su Anatomía de la críti-

6. Batjín aborda su estudio de la menipea en un intento de perfilar el fructífero ámbito de los géneros "cómico-serios" - -en el que destacan, por su trascendencia posterior, el diálogo socrático y la sátira menipea--, cuyo denominador común reside en la percepción carnavelesca del mundo, clave de su particular relación con la realidad, donde se difumina la distancia épica o trágica, donde el peso de la tradición cede a los imperativos de la experiencia y libre invención, y donde la unidad de estilo se fragmenta en una pluritonalidad y pluriestilismo en el que, junto a las máscaras para el autor se observa una actitud radicalmente nueva hacia la palabra - palabra "que representa" junto a palabra "representada" (Batjín, 1988, págs. 151-154). Este último aspecto fue retomado por J. Kristeva en su Semiótica, donde, bajo el epígrafe "La menipea: el texto como actividad social", procede a un análisis del discurso dialógico de la menipea a partir de Batjín. Para Kristeva, esa actitud nueva hacia la palabra se cifra en que "el lenguaje parece fascinado por el "doble" (por su propia actividad de trazo gráfico que dobla un "exterior"), y por la lógica de la oposición que reemplaza a la de la identidad en las definiciones de los términos [...] la menipea se estructura así como una ambivalencia, como un hogar de las dos iendencias de la literatura occidental: la representación mediante el lenguaje como puesta en escena, y exploración del lenguaje como sistema correlativo de signos" (Kristeva, 1978, I, pág. 216).

7. "El contenido existencial cobró en (la menipea) una forma genérica estable con una lógica interna que determina la unión indiscutible de todos sus elementos. Gracias a ello, el género de la menipea pudo adquirir una enorme importancia aún no apreciada por la ciencia, en la historia del desarrollo de la novela europea... El principio unificador que relacionaba los más variados elementos en un todo orgánico de género, principio de una fuerza y vitalidad excepcionales, fue el carnaval y la percepción carnavalesca del mundo" (Batjín, 1988, págs. 168-69 y 189). 
$c a$, insistiendo en el carácter netamente ideológico de sus formulaciones. En la parte correspondiente a la "teoría de los géneros", y ocupándose de la narrativa en prosa - fiction-, aborda Frye - "grand artisan de fearful symmetries", según Gérard Genette ${ }^{8}$ - el estudio de la sátira menipea en un intento de delimitar los perfiles de un tipo de fiction "intelectual-extrovertida" (Frye, 1969, pág. 416), y a la cual vendrá a denominar anatomía, término que juzga más adecuado que el de sátira menipea para designar este tipo de composiciones ${ }^{9}$, escritas mayoritariamente en prosa, pero que se caracterizan por el uso ocasional de verso intercalado:

La satira menippea non si occupa tanto della gente in sè quanto degli attegiamenti mentali [...] La satira menippea assomiglia quindi alla confessione nella sua capacità di trattare idee astratte e teorie, mentre diferisce del romanzo per ciò che riguarda la caratterizacioni dei personaggi, che è stilizzata piuttosto che naturalistica; essa tende a presentare le persone come portavoci delle idee che esse rappresentano" (Frye, 1969, págs. 417-418)

Estilización, pues, de los personajes, erigidos en portavoces de sus ideas, que redunda en una característica esencial de la menipea: "una visione del modo attraverso un unico schema intellettuale" ${ }^{10}$, que llega a violentar en ocasiones la lógica narrativa, fruto de esa singular combinación entre fantasía y moralidad que presenta siempre la menipea, predomine uno u otro componente. La forma más breve y condensada de sátira menipea, añade Frye, es, normalmente, un diálogo o coloquio "in cui l'interesse drammatico è concentrato su un conflitto de idee piuttosto che di personnagi" (Frye, 1969, pág. 419). Este esquema, que puede ampliarse a modo de "Symposium", contempla siempre un rasgo que lo individualiza: lo que Frye denomina "tratamiento creativo de la erudición omnicomprensiva":

8. "Quand Frye, autre grand artisan de fearful symmetries, observant l'existence de trois types de fiction: personnelle-introvertie (le roman romanesque), personnelle-extravertie (le roman réaliste), et intellectuelle-introvertie (l'autobiographie), en déduit celle d'un genre de fiction intellectuelle-extravertie, qu'il baptise anatomie, et qui rassemble et promeut quelques laissés-pour-compte de la narration fantaisiste-allégorique tels que Lucien, Varron, Pétrone, Apulée, Rabelais, Burton, Swift et Sterne, on peut sans doute contester la prócedure, mais non l'intéret du résultat" (Genette, 1979, pág. 50).

9. Basándose en la Anatomy of Melancholy de Burton, "il piú grande essempio di satira menippea prima di Swift", considera Frye que "la parola anatomia, nell titolo dell'opera di Burton, significa dissezione $o$ analisi, ed esprime con molta precisione la tendenza intellettuale della forma usata. Perciò possiamo adottarla come il termine piú approppriato a sostituire l'impacciante e ai nostri giorni piuttosto fuorviante satira menippea (Frye, 1969, pág. 421). Manejamos esta edición italiana por ser la única de que disponemos en este momento.

10. "La struttura intellettuale che emerge dalla storia raccontata -añade Frye - provoca violente alterazioni nella normale logica narrativa, sebbene l'effetto di trascuratezza che ne risulta rifletta solo la trascuratezza del lettore o la sua tendenza a giudicare secondo una logica narrativa basata sui principi del romanzo" (Frye, 1969, pág. 418). 
L'autore, che si trova a trattare temi e attegiamenti intellettuali, manifesta il suo impeto creativo intellettualisticamente, accumulando una gran massa di dati eruditi sul tema trattato o soprafacendo i pedanti che sono il bersaglio della sua critica con un uso spropositato e travolgente della loro stessa terminologia (Frye, 1969, pág. 420)

Estas consideraciones de Northrop Frye, sumadas a la brillante exposición de Batjín, contribuyen a esclarecer la predisposición forneriana hacia la tradición de la menipea como molde estructural que acogiese su designio crítico; la naturaleza eminentemente doctrinal de estas obras, encaminadas a ilustrar y defender unos presupuestos — lo que Batjín denomina la "verdad", la "idea" -y donde el análisis crítico - la "disección", la "anatomía"- de la realidad se encamina a enjuiciar su grado de adecuación con dichos presupuestos, se acomoda perfectamente a la condición esencialmente normativa de la labor crítica que siempre defendiera Forner, y se hace evidente en las Exequias, donde los personajes principales son fruto de una elección consciente y deliberada por parte del autor, quien los dota a priori de una incuestionable carga ideológica, proyectándose en todos ellos arropado en la multiplicidad de disfraces que le proporcionan las diversas voces; desde todas ellas, Juan Pablo Forner realiza, como bien señalara el profesor Maravall, "la crítica de todo un siglo" " , y es en el deseo de levantar acta del tiempo que le tocó vivir, a través de un memorial literario donde condensa las múltiples facetas de su quehacer, al tiempo que expone las bases que han de sostener la inexcusable reforma que ponga a España en condiciones de ser culturalmente operante, donde la elección del molde genérico de la menipea adquiere pleno sentido. Las propias consideraciones fornerianas a propósito de la naturalza de la tarea crítica y los límites del campo de aplicación de la sátira, ilustran la consonancia del género de la menipea con la voluntad que le movía al emprender el proyecto de las Exequias de la lengua castellana.

Es en 1780 cuando Juan Pablo Forner se apresta a dar su primer paso en firme en la república de las letras, con la redacción del Cotejo de las Eglogas que ha premiado la Real Academia de la Lengua, donde sale a defender el mérito poético de Meléndez Valdés frente a un airado Tomás de Iriarte que no había sabido refrenar su malestar ante el fallo del jurado que premiara ese año la égloga de Batilo. Aunque bajo su forma pulidamente académica el Cotejo de las Eglogas responde, en último término, a una mal disimulada voluntad

11. El espíritu de crítica y el pensamiento social de Feijoo", Cuadernos Hispanoanericanos, CCCXVIII (1976) - ahora en Maravall, 1991-. La dimensión crítica de las Exequias y su valor de reflexión sobre las señas de identidad de la cultura española fueron abordados por el profesor Maravall en su excelente artículo "El sentimiento de nación en el siglo XVIII: la obra de Forner", La Torre (Puerto Rico), 17 (1967) --también Maravall, 199l_, recordando la necesidad de que fuesen leídas a la luz de textos como la Oración Apologética, contemplando su sentido más allá de la inmediata defensa e ilustración de la lengua castellana que lleva a cabo en sus páginas. 
polémica, que anuncia veladamente al inminente Forner satírico: demostrar razonadamente la ignorancia de Tomás de Iriarte en lo que a las reglas de composición de la égloga se refiere y, por extensión, su desconocimiento de la esencia de la verdadera poesía, que no es únicamente "un arte sujeta a la jurisdicción de las orejas" (Forner, 1951, pág. 3), esta pequeña obra primeriza de Forner bien merece el calificativo, dentro de la estética ilustrada española, de "claro retrato del espíritu del siglo" con que la destacaba Fernando Lázaro en la excelente introducción a su edición del texto, ponderando la coherencia de su planteamiento y desarrollo respecto del concepto de crítica que Forner esboza en las primeras páginas, donde, tras exponer los motivos que propiciaron su redacción, y dispuesto a demostrar que la égloga de Iriarte "no tiene de égloga más que el título", advierte:

Y como los juicios que se hacen tan resueltamente penden, no del gusto particular del que lee, sino de la aplicación de los decretos del Arte a lo que se examina, habiendo yo hecho esta aplicación en el entendimiento, me ha parecido conveniente trasladarla al papel... (Forner, 1951, pág. 5)

La naturaleza doctrinal y autoritaria de la crítica literaria, tal y como se perfila ya en este Cotejo de las Eglogas, nunca será abandonada por Forner, cuyo sentido doctrinal y normativo de la crítica se proyectará con nitidez sobre cualquier esfera a la que se aplique su examen, más allá del ámbito estrictamente literario: ello se pondrá claramente de manifiesto unos años después, a la altura de 1787-88, momento en que Forner tendrá oportunidad de volver repetidamente sobre la naturaleza de la crítica y de la tarea del crítico, en el contexto de la polémica suscitada por la aparición de su Oración Apologética, polémica que propició la redacción de una serie de escritos de réplica donde Forner, al margen de las descalificaciones y los insultos que dedica a los papeles periódicos que atacaron su Oración, efectúa algunas consideraciones esclarecedoras a propósito de la labor crítica, advirtiendo que:

decir que una obra es mala es cosa fácil: algo más difícil es criticar por principios, esto es, demostrar la repugnancia de algunas obras con los preceptos de las artes a que pertenecen; pero es dificilísimo sobre todo dar el ejemplo con la crítica, y manifestar lo que se debe de hacer en vista de lo que no se ha hecho ${ }^{12}$.

En 1787, pues, Forner reclamaba para su Oración una crítica "ejemplar", aquella que se aplicase — fuese cual fuese su objeto- a "manifestar lo que se debe de hacer en vista de lo que no se ha hecho", de la misma forma que el

12. Forner, 1787, pág. 16. Según declara en carta al ministro Floridablanca, Forner compuso el Pasatiempo para "escarmentar la turbulenta audacia destos críticos que viven de serlo; y para desengaño de muchos, que ignorantes en este género de composiciones, se tragan buenamente los sofismas y absurdos más desatinados". 
crítico literario se aplica a juzgar las obras a la luz de los preceptos del Arte, de "lo que se debe de hacer", e insistía, por los mismos días, tras declararse "amantísimo de la crítica", perfilando con claridad el objeto de sus consideraciones:

Solamente es verdadero crítico, y verdadero reformador, el que haciéndose cargo del estado que tienen las doctrinas y las costumbres en su patria, nota en ellas los abusos, vicios o faltas fundamentales, no por capricho o sistema particular, sino poniendo siempre la mira en la verdad y utilidad de las cosas, explicándolas con orden y claridad, y haciendo practicables sus documentos ${ }^{13}$.

No dejó jamás de insistir Forner en la necesidad de que la crítica se asentase sobre la doble condición de censura razonada y fundamentada en una "verdad", punto de mira al que obligatoriamente ha de tender, y no dejó de denunciar la inutilidad y el daño de aquella crítica que, a su juicio, se precipita por la vertiente del — por utilizar sus mismas palabras- "lo que no se ha hecho", olvidando su otro componente fundamental, con el que debe contrapesarse armónicamente. Es precisamente este convencimiento el que le llevaba a responder puntualmente a las críticas suscitadas en la prensa periódica por su Oración Apologética, lamentando el ejercicio de una tarea que, a su modo de ver, no tenía de crítica más que el nombre, redundando en perjuicio de las letras de la nación, y es asimismo el espíritu que anima su censura del crítico enloquecido que aparece en las Exequias, "pobre frenético" que siembra el pánico entre los moradores del Parnaso, aquejado de la más maligna de las dolencias que en su día lamentara ya el padre Codorniu: la envidia, que le convierte en viva encarnación del desatino general que, a los ojos de Forner, gobierna el ejercicio de la crítica, caída en manos de hombres "ineptos siempre para mantener el debido temperamento en las cosas":

El crítico de bien debiera notar los defectos para ayudar a la entera perfección de las obras. Pero, ¿quién es el que se mueve a criticar con fin tan generoso? La primera intención del crítico es siempre desacreditar la obra ajena, para deprimir el mérito ajeno; la segunda, dar a entender al público que él sabe más que aquéllos cuyas obras merecen estimación universal, pues prueba, a su parecer, que no valen nada. Con estos fines suelen mezclarse de ordinario pasiones y designios más indecentes: la envidia, el odio, la venganza, y de aquí las calumnias, los dicterios, la infame maledicencia y todos los vicios que abortan la destemplanza y malignidad de ánimos perversos. (pág. 80)

13. Forner, 1787b, págs. 15-16. Al igual que el opúsculo anterior, las Demostraciones Palmarias, redactadas "para ver si quiere Dios que nos libremos de una vez de esta plaga de críticos y discursistas menudos que nos aturde", merece destacarse, al margen de los ataques que prodiga a la que denomina "Terna Periódico-Magistral", por las consideraciones a propósito de la urgente reforma "con sistema y diseño ordenado" que viene precisando España, y a la cual responden, en último término, las Exequias, para cuya comprensión es necesario tener muy en cuenta del desarrollo de la polémica suscitada por la Oración. 
Estos reproches venían a coincidir estrechamente con los que su odiado Tomás de Iriarte vertiera, unos años antes, en otra sátira menipea, Los literatos en Cuaresma, donde había alertado sobre los peligros que acechaban a la crítica con palabras que sin duda hubiera suscrito Forner, salvo en un extremo significativo: el matiz despectivo con que el fabulista alude a la sátira, a la que contempla, de hecho, como un forma degradada de crítica, que suplanta a la verdadera digna de tal nombre cuando cae en manos de ingenios de "cortísimos estudios", proclives a las tentaciones de la envidia y el afán de notoriedad:

La crítica da valor a las cosas, y sin ella nos exponemos a dejar lo arreglado por defectuoso, pero la crítica también está, sin duda, reputada por la más fácil de todas las facultades, puesto que con estudios cortísimos se precia cualquiera de profesarla. En teniendo bastante libertad para satirizar, hay quien crea que ya sabe criticar bien [...] tengamos Emulación, pero huyamos de la Envidia; critiquemos dando razón de lo que criticamos, pero no satiricemos por capricho, ni sólo por deseo de acreditarnos, que para quien aspire a la inmortalidad literaria, es muy estrecho el campo que ofrecen las imperfecciones ajenas y muy dilatado el que las mismas ciencias nos tienen siempre patente (Iriarte, 1805, VII, págs. 23 y 28-29).

Forner no podía estar de acuerdo con este juicio: satírico impenitente, se aplicó de forma repetida a recordar no sólo los rasgos que han de definir el recto ejercicio de la crítica, sino también los límites que la separan de la sátira, reservando sin embargo para ésta un lugar propio y definido, legitimando insistentemente su uso en función de la finalidad "higiénica" perseguida. Por ello, la insinuación iriartiana de la dependencia del ejercicio satírico para con la envidia -idea que combatió incansablemente - había de exasperarle cuando, en 1785 , la viese repetida y afirmada abiertamente por Vicente García de la Huerta en su Lección Crítica a los lectores del papel intitulado "Continuación de las memorias críticas de Cosme Damián”, opúsculo con el que Huerta venía a responder a las críticas que había suscitado su Theatro Hespañol, y que provocó a su vez la demoledora respuesta forneriana que, bajo el título de Reflexiones sobre la "Lección Crítica" que ha publicado D. Vicente García de la Huerta, constituye seguramente la más clara manifestación de la postura de Forner respecto del uso de la sátira en el ejercicio crítico: García de la Huerta había arremetido en su Lección Crítica contra Miguel de Cervantes, "preceptista charlatán", cuya pluma, así en el Quijote como en el Viaje del Parnaso, había sido movida por la "envidia", y tras sentar que, en su juicio, "siempre serán sinónymos los nombres de crítico, satírico y envidioso" ${ }^{14}$, calificaba ambas obras

14. García de la Huerta, 1785, pág. xxx. La Lección Crítica de Huerta es, de hecho, una respuesta al ataque efectuado por Samaniego a su Theatro Hespañol, cuyo primer volumen apareció ese mismo año, siendo objeto de innumerables sarcasmos por lo estrafalario de sus juicios. 
de "satiricón completo" y "durísima invectiva", respectivamente. La respuesta de Forner no se hizo esperar: asido a la irritante "sinonymia" de Huerta, se propuso demostrar que "tal sinonymia es enteramente falsa, no sólo en buena gramática, sino en buen juicio, y en buena experiencia" (Forner, 1785, pág. 29):

Enseñémosle la utilidad de la buena sátira y el mérito de los buenos satíricos, y demostrémosle que un buen crítico, lejos de ser envidioso, debe ser envidiado, y que sólo suelen desacreditar a los buenos críticos los que quieren escribir disparates impunemente.

La sátira, tomada en su acepción más general, no es otra cosa que una enérgica reprensión de las viciosas costumbres de los hombres [...] pero aunque en la Poética se trata de este especial poema que se llama sátira, hay con todo eso otras obras de ingenio en uno y otro estilo, esto es, en prosa y en verso, y a veces en ambos a un tiempo mismo, que se intitulan también satíricas por el modo, por el objeto, y por la materia. Por el modo: porque tratan el argumento, sujeto, o asunto en tono festivo o irónico. Por el objeto: porque se dirigen a la corrección de uno o muchos vicios. Por la materia: porque no enseñan la fealdad de los vicios directamente, como se hace en la Filosofía Moral, sino haciéndolos ridículos, mostrando la irrisión que se merecen, y exponiéndolos a la mofa y burla de los lectores (Forner, 1785, pág. 29).

Amparándose en Platón, Horacio, Luciano, Séneca y Patronio, y con el pie en el estribo de los textos de Juvenal, Vives, o el propio Cervantes, Forner defendía airadamente la dignidad y licitud de la buena sátira en el caso de "intimidar a los ignorantes, a los jactanciosos y a los perversos, logrando efectos en la mejora de las costumbres que no logran las mismas leyes, porque no pueden extenderse a ciertos abusos" ${ }^{15}$, con lo cual establecía tácitamente los límites que la separan de la censura crítica en sentido estricto: Su oportunidad habrá de asentarse en la naturaleza del objeto tratado, en la medida en que por su calidad merezca una crítica que enfatice su condición ridícula: "un avaro, un truan, un adulador, un soberbio, un vano, un caprichudo, un mal versificador...", todos aquellos que merecen "ser castigados con la irrisión y el desprecio", no siendo pues acreedores de aquella crítica ponderada y equilibrada, justa y ecuánime, que reivindicará repetidamente dos años después, al calor de la contienda "apologética". Esta era, precisamente, la advertencia que había dirigido, un año antes, a Cándido María Trigueros al disponerse a iniciar el análisis crítico de su poema La Riada:

15. Forner, 1785, pág. 47. En un pasaje de la redacción primitiva de las Exequias (ms. 122 de la Real Academia), que desaparecerá en las redacciones posteriores, insiste Forner en el mismo sentido: "Donde no reina la buena sátira triunfan a una el pedantismo y la charlatanería. Los abusos literarios admiten más llana enmienda que los civiles. Haced ridículo a un mal poeta, a un mal orador, a un filósofo en apariencia, poniendo en claro las estrafalarias consecuencias de su ignorancia, y vereislos prontamente desesperarse, y corregido de muchos el defecto que se desacreditó en uno". 
Dexando en buen lugar el mérito literario de Vm., hablaré de su obra con ingenuidad y moderación, cual conviene entre gentes que no combaten, sino disputan. La sátira, que es el mejor correctivo de los abusos, se emplea admirablemente cuando se trata de hacer bajar el toldo a un pedante, de ridiculizar a un versificador hinchado, o de contener el magisterio de un insolente preceptista; pero en las cuestiones, donde al carácter ingenuo y recto de las personas se junta la averiguación de una verdad útil, el uso de la sátira sería no sólo injusto, sino dañoso. Aquel quid deceat, quid non de Horacio, es documento que no se limita sólo a la fábrica de los poemas. (Forner, 1784, pág. 6)

Forner se aprestaba, en este caso, a realizar un ejercicio de crítica, que no excluía la dureza de los comentarios burlones con que lo adornaba, pero que no menoscaban el hecho de ser esta su Carta de Antonio Varas al autor de "La Riada" una censura rigurosa a partir de los preceptos que han de regir la composición de un poema épico: no tenía cabida la pura sátira, tratándose de la averiguación de una "verdad útil", cometido esencial de la tarea crítica siempre defendida por Forner. Por ello, cuando en la "Noticia del Licenciado Pablo Ignocausto" que abre las Exequias, declare haber sido la doble intención al componer la obra "manifestar las fuentes del buen gusto en el uso de la lengua castellana, declarando la guerra a sus corruptores antiguos y modernos" (pág. 18), dará la razón de ser de la imposibilidad de investirse aquí de puro satírico: la sátira convenía plenamente a la segunda de las intenciones mencionadas, no así a la primera, "verdad útil" cuya averiguación y demostración no se correspondía con la naturaleza del ejercicio satírico. Era, pues, menester conjugar la voluntad doctrinal y normativa de la crítica con la higiénica propia de la sátira, y sería el ilustre género de la menipea quien le proporcionaría molde adecuado para la conjunción de ambas calidades: si en la Carta de Antonio Varas envolvía el rigor y la puntualidad necesarios a la censura con un ropaje que no desdeñaba el tono satírico y burlesco, la doble finalidad de las Exequias precisaba de un género en cuyo seno se conciliasen el humor y la seriedad de la doctrina, la burla y la averiguación de una verdad.

Y esa "verdad útil", "asunto principal" de las Exequias, aparece, como advertía el propio Forner, "casi al final" de ellas: condensada en el discurso fúnebre de Apolo que cierra el desfile funeral, donde viene a recordar la urgente necesidad de que los literatos españoles vuelvan los ojos hacia sus mejores modelos, y se apliquen a su estudio y juiciosa emulación _- "Mientras no se restaure en vuestra Patria la juiciosa emulación de sus estilos, la lengua yacerá en el estado que veis, desmayada, postrada, marchita, enferma, finalmente, y en riesgo de fallecer para eterno oprobio de vuestro descuido" (pág. 182 ) —, en aras de conseguir pleno dominio y conocimiento de la verdadera elocuencia castellana, para poder aspirar así a una buena imitación de los me- 
jores escritos extranjeros: una imitación que no se asiente en el servilismo a manos de los modismos foráneos adoptados indiscriminadamente, sino cifrada en el reconocimiento y asunción de los mejores logros de los "escritos ajenos", discerniendo aquello que aprovecha imitar, de aquello que conviene huir y rechazar en la medida que repugna al "genio" y "gusto" linguístico propio. Sólo desde el cabal conocimiento del auténtico genio de la lengua castellana, de su verdadera "abundancia y fertilidad", depositada en la obra de sus mejores escritores - los que desfilan en la pompa funeral-, que han de servir de pauta y modelo sabiamente imitados, viene a decir Forner, puede acometerse aquella buena imitación de los escritos extranjeros —no debe soslayarse la importancia de esta idea - que ha de redundar en el provecho de nuestras letras.

Pero hasta llegar a las palabras de Apolo, este importante concepto, de múltiples implicaciones, de la buena imitación o juiciosa emulación, piedra de toque del pensamiento forneriano en las Exequias, ha recorrido el texto, vertebrándolo, y han sido especialmente tres personajes, Cervantes, Mayans y Villegas, quienes se han hecho portavoces de la doctrina que articula el sentido de la menipea ${ }^{16}$. Personajes escogidos conscientemente por Forner, quien habla por boca de todos ellos, proyectándose repetidamente en su imagen y sus palabras: al margen de su voluntaria insistencia en encarnar su pensamiento y sus juicios en personajes de quienes pudiera destacar deliberadamente su poca fortuna pública y el menguado reconocimiento que merecieran, en vida, sus producciones - aspecto que se repite, de una u otra forma, en la caracterización de todos ellos, y que es indesligable de la insistente y sabiamente esgrimida convicción forneriana de formar parte de aquellos ingenios privados del "poder tiránico crítico" ejercido por quienes gozan del favor oficial, viéndose abocado a todo tipo de riesgos y sinsabores ${ }^{17}$-son el satírico ejemplar, a cuyo Viaje del Parnaso rinde homenaje la menipea forneriana, el riguroso erudito enfrentado airadamente a las directrices de la cultura oficial, encarnada aquí por los redactores del Diario de los Literatos de España, y el poeta anacreóntico modelo de elocuencia castellana en el quicio de los dos mayores siglos de su

16. Es Miguel de Cervantes quien, en los primeros compases de la obra, expone a Aminta y Arcadio el estado científico y literario de la nación en virtud de la indigencia de buenos libros que "sostengan el crédito de la nación"; será Mayans quien, en su intervención, formule con claridad el necesario estudio y "buena imitación" de nuestros clásicos para poder acometer una correcta imitación de los escritos extranjeros; y será seguidamente Villegas quien se encargará de exponer y razonar extensamente el aserto mayansiano, conformando el ideal de elocuencia castellana que ha de ser norte y guía para los jóvenes literatos.

17. Esta convicción surge con insistencia a partir del pleito desatado con los Iriarte a raíz de Los Gramáticos, y tendrá un eslabón significativo en el incidente provocado por la Carta de Antonio Varas, el consiguiente enfrentamiento con la Real Academia, y la prohibición a Forner de satirizar en adelante a persona particular o cuerpo alguno. Años después recordaba, en la "Noticia del Licenciado Pablo Ignocausto", las "pesadumbres" con que éste tropezara, las "persecuciones" de que fuera objeto, y el "encono y coraje" con que fuera tratado. 
literatura, quienes conducen significativamente el desarrollo de dicha idea en las Exequias. Acompañándoles, Aminta y Arcadio, los dos poetas viajeros, bajo cuyos nombres poéticos, recuerdo de los años salmantinos, se esconden respectivamente el propio Forner y José Iglesias de la Casa: frente a los largos silencios de Aminta, que se sitúa, en buena parte de la obra, como mero espectador, es en Arcadio en quien delegará Forner la tarea de suscitar el diálogo, apuntando, corroborando o matizando las ideas que en los sucesivos encuentros van dirimiéndose; y frente a Arcadio, que asume en buena medida el punto de vista del poeta novel que pasea su mirada curiosa y admirada por el Parnaso, Forner se reserva a sí mismo, bajo el disfraz de Aminta, el orgulloso y sintomático papel de quien es llamado por el propio Apolo para contemplar el funeral de la lengua y permanecer en adelante en los dominios de la Poesía, recorriendo el Parnaso con aire seguro y confiado en su rol de distinguido invitado - sutil diferencia con Arcadio, que se suma al viaje excitado por la curiosidad-, a quien se dirigen los consejos y admoniciones de Apolo, quien ha organizado para él la fabulosa pantomima del funeral, escogiéndolo como singular emisario y portavoz de sus designios ${ }^{18}$.

Convocados todos ellos por la pluma de Forner a llorar la muerte de la lengua castellana, los personajes principales de las Exequias concurren a la ficción para ser portavoces del pensamiento del autor, defenderlo y demostrarlo, y los sucesivos encuentros se disponen para avanzar, matizar o contrastar su exposición: ello permitía a Forner dejar constancia de las múltiples facetas de su producción intelectual y demostrar su gran erudición, pero, ante todo, le permitía trabar concienzudamente, a través de una multiplicidad de voces que son la suya propia, la verdadera dimensión de aquella insoslayable "verdad útil" que hacía del todo impropio el uso de la pura sátira, y que constituye el objetivo primordial de su menipea: "Declarar las fuentes del buen gusto en el uso de la lengua castellana", para encarecer y promover su restitución como lengua de cultura, capaz de producir aquellos que Arcadio denomina "libros clásicos de las naciones [...] Estos libros propagan las lenguas, doctrinan los pueblos, y andando en manos de todos, siembran, mantienen y multiplican en todos tiempos las ideas de lo mejor en literatura [...] no creo que se haya pensado aun en España que una nación no puede ser gloriosa ni admirada, ni tenida en alguna consideración, sin esta especie de libros" (págs. 91-92). A ello se consagran las Exequias de la Lengua Castellana, recordando con insistencia la urgente y necesaria vuelta a los mejores modelos de elocuencia, y promoviendo una recta y juiciosa emulación de los escritos extranjeros, en busca de

18. El personaje de Arcadio enfatiza la singular condición de "elegido" de Aminta, al convertirse en portavoz de sus pensamientos, entrando en diálogo generalmente con el resto de personajes, suscitando réplicas y explicaciones doctrinales, o tomando la palabra para pronunciarlas él mismo, permitiendo de este modo que Aminta consagre su papel de privilegiado testigo, cuyas intervenciones directas son mucho más escasas. 
los mejores hallazgos que habrán de ser vertidos con propiedad y discreción, respetando el genio de la lengua. Junto a ello, también, la intención de "declarar la guerra a todos sus corruptores antiguos y modernos": poetastros ineptos, pedantes, escritorzuelos a sueldo, papelistas charlatanes y filosofastros que surgen para ser blanco de los dardos satíricos de Forner a lo largo del texto, y a quienes reserva, ahora sí, la dureza de la sátira en tercetos que cierra la ficción alegórica, donde se hace explícita la coyuntura desde la cual emprende Forner esa "crítica de todo un siglo".

A "bajarles el toldo" se encamina la agria Sátira contra la literatura chapucera de estos tiempos, que, redactada contemporáneamente a la configuración de las Exequias como texto completo, y dirigida "contra la faramalla literaria del tiempo" 19 , halló acomodo en la amplitud de una obra cuya intención y sentido iban bastante más allá de aquel "intimidar a los ignorantes, a los jactanciosos y a los perversos, logrando efectos en la mejora de las costumbres que no logran las mismas leyes" que reconocía como propio de la "buena sátira", verdadera policía de la república literaria: se trataba de un auténtico testamento literario donde Forner venía a contestar su acerba, violenta y dolorida reflexión sobre la cultura española, exponiendo un necesario proyecto de reforma que había de poner a España en condiciones de sujetar su paso al de las naciones cultas de Europa, y donde quiso dejar constancia de las directrices que gobernaron siempre su pensamiento y su pluma. El género ilustre de la menipea le proporcionó molde adecuado para la doble finalidad que perseguía al acometer una tarea crítica en cuyo seno vinieron a conjugarse dos de las facetas de su amplio quehacer y que no pueden contemplarse sino unidas en el ámbito de una misma y persistente reflexión sobre la cultura española: la apología y la sátira, bajo la égida de un género libre y flexible como pocos, cuya amplitud de márgenes permitió que el crítico, el satírico, el apologista, el jurisconsulto y el historiador que fue Juan Pablo Forner levantasen acta de un

19. La Sátira fue compuesta, según testimonio del propio Forner, a finales del verano de 1788 , y en ella reconocía haberse puesto "al lado de Pitillas" (Carta a Eugenio Llaguno del 16-IX-1788). Merece la pena contrastar ambas sátiras, separadas por más de cuarenta años, para contemplar cómo el panorama que en 1741 veía perfilarse "Pitillas" en la literatura, con la proliferación de términos pseudocientíficos en la poesía, y el uso indiscriminado de galicismos que empezaban a abundar como peligrosa moda, abocando a un horizonte de superficialidad y pedantería, es recogido por Forner en una vioienta diatriba contra la "oscura niebla" de "sueños opulentos" que envuelve a los literatos españoles, y que se introduce en las Exequias de la mano de Apolo, cuando, tras el discurso fúnebre que dirige a los dos protagonistas exponiendo los motivos del pretendido funeral de la lengua - "manifestaros con la vista de tanto hombre insigne lo mucho que va a perder España si dejan pcrecer el instrumento de sus glorias" (pág. 181)-, invita a los presentes a presenciar "no ya en solemnidad fúnebre, sino en castigo merecido, el que deben sufrir los detestables abortos de la barbarie" (pág. 183). Tras de la "solemnidad" de la doctrina y la "verdad útil", el "castigo" y la "irrisión": la invitación a la lectura pública por parte de Aminta de una sátira en tercetos donde "diste con lo cierto de las causas que han destruido en España su lengua y la celebrada solidez de sus sabios. Los males son profundos y peligrosos, y su remedio no está en disimularlos, sino en of recerlos a la irrisión del mundo. Lee, pues" (pág. 186). 
tiempo en el que, como recordaba con justica Fernando Lázaro, "polemizó por necesidad irreprimible" ${ }^{20}$, plasmando a través de un "viaje al Parnaso" de estirpe cervantina las claves de su esfuerzo por incorporar el pensamiento y las letras españolas, no sólo al ritmo de sus tiempos mejores, sino por él, a través de él, al ritmo de los tiempos presentes.

\section{BIBLIOGRAFÍA}

BATJín, M. 1988. Problemas de la poética de Dostoievski, México, Fondo de Cultura Económica ( $2^{\mathrm{a}}$ ed.)

CUETO, L.A. 1952. Poetas líricos del siglo XVIII (II), B.A.E., LXIII, Madrid, Atlas.

FORNER, J.P. 1784. Carta de Antonīo Varas al autor de "La Riada". Madrid, Imp. de Miguel Escribano.

- 1785. Reflexiones sobre la "Lección Crítica" que ha publicado D. Vicente García de la Huerta, Madrid, Imprenta Real.

- 1787a. Pasatiempo de don Juan Pablo Forner en respuesta a las objeciones que se han hecho a su Oración Apologética por la España, Madrid, Imprenta Real.

- 1787b. Demostraciones Palmarias de que el Censor, su Corresponsal, el Apologista Universal y los demás papelejos de este jaez no sirven de nada al Estado ni a la Literatura de España, Madrid, s.i.

- 1951. Cotejo de las Eglogas que ha premiado la Real Academia de la Lengua (ed., prólogo y notas de F. LÁZARO), Salamanca, C.S.I.C. / Colegio Trilingüe de la Universidad.

- 1967. Exequias de la Lengua Castellana (ed. de P. SAINZ RODRIGUEZ), Madrid, Espasa-Calpe, "Clásicos Castellanos".

FRYE, N. 1969. Anatomia della critica, Torino, Einaudi.

GARCÍA DE LA HUERTA, V., 1785. Lección Crítica a los lectores del papel intitulado "Continuación de las Memorias Críticas de Cosme Damián". Madrid, Imprenta Real.

GENETTE, G. 1979. Introduction à l'architexte, Paris, Editions du Seuil.

IRIARTE, T. 1805. Colección de Obras en verso y prosa, 8 vols., Madrid, Imprenta Real.

KRISTEVA, J. 1978. Semiótica, 2 vols., Madrid, Fundamentos.

LÁZARO, F.1985. Las ideas lingüísticas en España durante el siglo XVIII, Barcelona, Crítica, $2^{\mathrm{a}}$ ed.

LÓPEZ, F. 1976. Juan Pablo Forner et la crise de la conscience espagnole au XVIIIe siècle, Bordeaux, Université de Bordeaux.

20. Forner, 1951, pág. xi. Ya se había referido el profesor Lázaro a Forner como "la mente más clara del siglo, la que más certeramente observa el hundimiento moral y material que le rodea", y no dudaba en parangonarlo, en tanto que "alma gemela", a Miguel de Unamuno (Lázaro, 1985, pág. 238). 
MARAVALL, J.A. 1991. Estudios de la historia del pensamiento español (siglo XVIII), Madrid, Mondadori.

MENÉNDEZ PELAYO, M. 1974. Historia de las ideas estéticas en España, 2 vols., Madrid, C.S.I.C. 


\section{LEANDRO FERNÁNDEZ DE MORATÍN Y JOSÉ DE LUGO EN LONDRES (1792-1793)}

Jorge DEMERSON

Sabido es que José de Lugo hizo dos viajes a América del Norte, el primero antes del nacimiento de los Estados Unidos, en 1777, y el segundo en 1784-1785 (Demerson, 1988a, págs. 13-16).

Antes de realizar estos viajes, había estado en Inglaterra para aprender el inglés y conocer la vida y costumbres de los insulares.

A la vuelta de su segundo viaje a América, tras de permanecer una temporada en su patria chica, Tenerife, Lugo pasó de nuevo a Gran Bretaña en 1788. En ese país, como ya lo había hecho allí y en otras partes, trató de fomentar el comercio de los vinos de su tierra. Pero no se limitó al papel de corredor, activo por cierto, de los viticultores y vinateros de Canarias. Tenía más ambición. Procuró y consiguió que las autoridades inglesas modificasen la legislación aduanera de su país, poco favorable entonces a la importación de este artículo, cuya venta era recurso imprescindible para la economía del archipiélago guanche. Gracias a sus gestiones pacientes y tozudas, obtuvo del gobierno británico un decreto permitiendo que los vinos de Canarias pudiesen ir en derechura desde aquellas islas a la Jamaica y demás establecimientos ingleses de Asia, Africa y América: ventaja considerable, que favorecía notablemente la agricultura y el comercio canario.

Al defender y dar a conocer los productos de su tierra natal, Lugo actuaba "por puro efecto de su patriotismo", ya que no cobraba nada. Dijo más tarde que en esas campañas de promoción, gastó todo su patrimonio. Pero esa abnegación generosa y desinteresada no tardó en recibir la recompensa que se merecía. En efecto, en enero de 1793, sus coterráneos, a través del Consulado de Canarias, acordaron expresarle oficialmente su reconocimiento "por los 
beneficios que su patriotismo había procurado con el mayor desinterés al comercio de las islas, autorizándole con poder bastante para que en nombre de dicho Consulado promoviese y adelantase las demás pretensiones que tenía pendientes en la Corte de Londres". Acordó asimismo el Consulado "recomendarle a la piedad del Rey y solicitar su Real aprobación para recompensarle debidamente por los importantes servicios que había hecho, tanto más apreciables cuanto que habían sido practicados oficiosamente por el solo impulso del honor y del amor a la Patria" (ibíd., pág. 17). Prosperó la sugerencia del Consulado: el Rey nombró al tinerfeño agente de Canarias cerca de la Corte británica, o "encargado de negocios mercantiles en Gran Bretaña".

Ya era hora de que las autoridades reconocieran sus méritos y su desinterés porque a la sazón el hijo de la Orotava, que tenía 40 años, parecía estar a la cuarta pregunta. D. Francisco Caballero Sarmiento, que le trató entonces, habla "de la miseria en que Lugo estaba sumido en Londres" y le acusa explícitamente de haber vivido de gorrón: "cuando su tío Pepe, escribe a Sebastián de Lugo, sobrino de D. José, se hallaba en Londres viviendo a expensas de sus amigos y haciendo de garante principal en el club de los Jacobinos..." (Demerson, 1988b; se me antoja que el Club de los Jacobinos que denuncia Caballero Sarmiento podría ser el Club Hispanus, del que se hablará más adelante) arrastraba tras de sí crecidas deudas.

Fuera de esos apuros financieros que nos revela la correspondencia del Sr. Caballero Sarmiento, no sabemos nada de la vida que hacía el canario en la capital inglesa durante la Revolución francesa. Afortunadamente, otro español, madrileño por más señas, acertó a pasar entonces casi un año entero en esa Corte, desde el 27 de agosto de 1792 hasta el 9 de agosto de 1793. Este español, viajero curioso y "escribidor" impenitente, no era sino D. Leandro Fernández de Moratín, bien conocido en la capital de las Españas como poeta, luego comediógrafo y más tarde como el historiador del teatro español.

Ahora bien, tenía por costumbre Moratín — cosa poco frecuente entre sus compatriotas en esa época- escribir un diario en que iba consiguiendo lo que le ocurría cada día. Pero ese diario suyo no se parecía al que por los mismos años escribía D. Gaspar Melchor de Jovellanos. El asturiano apuntaba en castellano y en prosa corriente las principales cosas que hacía, las personas con que alternaba, las obras que leía o que se leían en su tertulia de Gijón, los proyectos que se proponía realizar, las noticias importantes que llegaban de la Corte o del país, etc. Algo parecido hacía por supuesto D. Leandro; pero concebía sobre todo ese diario como una especie de recordatorio muy personal, hasta confidencial. Por lo cual procuró conferirle un carácter esotérico, incluso secreto, con el fin de hacerlo incomprensible a los lectores eventuales. Varios contemporáneos suyos, como Cadalso y Meléndez Valdés, al perseguir el 
mismo fin de ocultar a veces algo que se escribían, usaron de una clave, de un lenguaje en clave (Demerson 1985). Moratín por su parte, adoptó otro método, el que su padre, Nicolás Fernández de Moratín, había usado en su diario. Leandro, pues, al heredar los papeles de su padre se limitó a seguir el ejemplo y el método paternales.

Empleaba palabras procedentes de cinco idiomas: latín, español, francés, inglés e italiano. Pero para dificultar aún más la interpretación de esa jerigonza o mezcolanza europea, abreviaba drásticamente, hasta reducirlas a dos o tres letras, a menudo consonantes, los vocablos de ese extraño cóctel, como se ve en el ejemplo siguiente:

\section{9.ch. ti.A. Fnt./ Fnt. Comª .2. Fnt. Me Mal.'}

Con paciencia y perspicacia admirables René y Mireille Andioc consiguieron descifrar ese jeroglífico y hacerlo totalmente inteligible. Y como el Diario de Moratín abarca casi 28 años, desde enero de 1780 hasta marzo de 1808 (con algunas lagunas importantes), el lector comprenderá el interés de ese documento extraordinariamente original que contiene un sinfín de informaciones y juicios sobre personas y acontecimientos de esos casi tres decenios, y en particular sobre el mismo autor que, creyéndose totalmente amparado y protegido por la clave que se había forjado, apunta confidencias y secretos que nunca jamás hubiera revelado voluntariamente.

1. Fernández de Moratín, 1967, 9 de diciembre de 1781, pág. 52.

El baturrillo lexicográfico usado por Moratín merece unas líneas.

El latín proporciona a Moratín, que parece dominarlo aunque lo aprendió solo, muchos verbos sobre todo en primera persona del pretérito perfecto - cosa lógica en un diario--: vidi, inveni, vidimus, risimus... El madrileño duplica a veces en este tiempo la consonante final del radical: lussimus (de ludere, lusi), futtui (de futere), etc. Además toma prestado del latín numerosas preposiciones o adverbios: cum, in, ex, ubi, usque, ad, super y cierto número de pronombres, sustantivos o adjetivos.

Del francés toma: il, ici, chez, manger, ambassadeur, nouvelle (noticia), promenade, returner (sic), voyage, Don Jacques (por Santiago), etc. dinero...

Del español, no rehuye usar palabras comunes: calles, libros, libreros, tragedia, gruñimiento,

Del inglés: house, mother, street (doble de casa, madre, calle), etc., que se encuentran también en el Diario. Sin embargo, por regla general, la elección que hace de un vocablo el autor es definitiva.

Al italiano toma prestados scherzi, notizia, etc. Son más frecuentes los italianismos después de 1793 cuando reside durante varios años en la península.

Algunos ejemplos, recogidos al azar, de la mezcla lexicográfica que compone el Diario:

Notizia ex declaratio belli ex Galicia (sic: Galia) ad Spain (marzo 1793).

Risi, nam il disputa cum French.

Reda, éxilé 8 days avant, madre plorans.

Ego seul in Strand manger.

Cum Lugo por chocolatero usque ad Bourse, ego despeado.

Cum Sames, chez Madame Barens, pictora danesa, vidi tableaux de fleurs.

La técnica de Moratín consiste en yuxtaponer palabras de distinta procedencia. Es evidente que no respeta la sintaxis latina: "spectans quaedam meretricula" (20-XI-1804). 
No hay por cierto, ningún secreto en el breve apunte que hemos propuesto como ejemplo. Quiere decir simplemente: "Domingo 9. Chez tía Anita; Fontana. / Fontana; Comedia 2; Fontana. Madre Mala". Esa Fontana, a la cual acudió tres veces en el mismo día Leandro de Moratín, era por supuesto el conocido café de La Fontana de Oro.

Lugo permaneció mucho más tiempo que Moratín en Inglaterra. Estaba ya en Londres, donde llevaba cuatro años cuando, el 27 de agosto de 1792, llegó a esa capital el futuro comediógrafo, provisto de una pensión que le había concedido Godoy; y el canario había de permanecer allí otros tres años — hasta 1796- después de la partida de D. Leandro, que tuvo lugar el 9 de agosto de 1793. Durante ese año no cabal que el futuro autor de El sí de las niñas pasó a orillas del Támesis, los dos compatriotas se encontaron y trataron a menudo: a veces sólo durante un almuerzo; a veces durante una tarde, otras durante un día entero, "hasta las 12 de la noche" como en una ocasión queda apuntado en el Diario. Incluso hicieron juntos y con otros compañeros una excursión a Southampton que duró 12 días, tiempo suficiente en verdad para que cada uno hiciese amplia cosecha de recuerdos en los que estaban mezclados los otros.

Salvo error u omisión, los nombres de los dos hombres, Lugo y Moratín, aparecen juntos en el Diario 46 veces, cifra que por sí sola manifiesta indudable compañerismo y hasta cierta intimidad. Llevaba ya mes y medio Moratín en la capital inglesa cuando se encontró por primera vez con Lugo, el 15 de octubre de 1792. Creo que no se conocían aún. Tomaron café juntos. Dos semanas después, el día 1 de noviembre, almuerzan el uno y el otro en casa del embajador español, invitación que el anfitrión, Marqués del Campo, rumboso, les repetiría en varias ocasiones. El 11 del mismo mes, ambos participan en otro almuerzo, pero esta vez, el que recibe es el Cónsul General de España, D. Manuel de las Heras, quien invitará varias veces más a éstos y otros compatriotas suyos.

Si bien Lugo fue para Moratín un acompañante frecuente, hubo otro español que lo fue podríamos decir que constante: Carlos Gimbernat (1764-1834) que se dio a conocer más tarde como geólogo, geógrafo, químico, "termalista" - valga la palabra - y autor de varios tratados científicos en francés, español y alemán ${ }^{2}$. Pero en 1792 , a los 24 años, Gimbernat no pasaba de ser, al igual que don Leandro, un simple becario del gobierno español: el año anterior, le habían concedido una pensión para estudiar en el extranjero, concretamente en Gran Bretaña.

2. Gimbernat trabajó también para los soberanos de Baviera. Estudió los vapores del Vesubio, y trató de aprovecharlos para obtener agua condensándolos, y también para curar ciertas afecciones. 
Entre el 11 de octubre de 1792 , en que sale por primera vez su nombre en el Diario y el día 9 de junio de 1793 en que desaparece, es decir en un período de ocho meses, el nombre de Gimbernat queda apuntado, salvo error, 272 veces en el cuadernillo del madrileño. Ciertos días, se va repitiendo hasta tres veces: así, el domingo 11 de noviembre de 1792: "Chez Gimbernat, breakfast; cum Lugo chez cónsul; cum il y Gimbernat in Strand Caféhouse manger. Calles. Gimbernat ici" (P. 90).

Y conste que en el anterior cálculo, sólo tuve en cuenta los casos en que aparece en el Diario el apellido de Gimbernat con todas sus letras; pero si contáramos las veces en que está representado por "il" ( o sea "él" en castellano) la cifra sería mucho más elevada.

El trato del comediógrafo y del geólogo fue tan continuo, tan constante que los dos hombres, que solían salir juntos de noche, al terminarse su trasnocho se quedaban a dormir ambos en aquella casa que les resultaba más cercana: o la de Moratín o la del catalán. Gimbernat y Moratín eran en Londres no digo como mellizos, pero sí como hermanos siameses. Y ese comportamiento se explica sin duda por la identidad de su situación social y económica: la de pensionados del gobierno español. Libres de sus movimientos, podían ocupar su tiempo a su antojo. Y Lugo, que tenía que ganarse la vida, sólo se juntaba con ellos cuando lo podía.

Entonces los tres hombres solían comer juntos, salir a callejear o a pasearse por la ciudad: se les veía en el parque Saint-James, en Hyde Park, en diferentes barrios londinenses. En ocasiones, capitaneados por Moratín, que era como todos sabemos un entusiasta de las representaciones teatrales, iban a la Comedia de Hay Market, el teatro de Covent Garden, el único aceptable en opinión del madrileño, al Templo de Flora, "risible spectacle", al Royal Circus donde se daba "una pantomima pestilente!". Por fortuna, en Hay Market se representaban a veces tragedias en que era protagonista la actriz Siddons, por quien Moratín sentía una profunda admiración: la juzga "optime" en uno de sus papeles. Ocurrió que los tres compadres entrasen en un baile popular; pero no tardaron en salir...

Por el Diario nos enteramos de los establecimientos adonde iban a almorzar (nunca se habla de cena): la Hostería de la calle Oxford, la Strand Café House, el Café près Saint Martin ( Tavern, the Oxford Tavern... También comen en el Sablonière, restaurante francés a cuyo dueño había conocido Moratín en París.

Otros días, sus salidas tienen un fin que hoy día diríamos más "cultural" que gastronómico; visitan el Museum Britanicum, o van "a videre Rinozeros" (sic). De Westminster hacen una visita detenida y asimismo de Saint-Paul 
Church. Otra vez, van "a videre linterna mágica". Ocurre que las excursiones sean de mayor envergadura: del 7 al 10 de mayo, Moratín apunta: "Cum Lugo, ad mar, in Southampton”. En el verano de 1793, se bañan en el Támesis...

Uno de los sitios en que solían reunirse los españoles residentes en Londres era el Club Hispanus, especie de peña nacional, organizado sobre el modelo de los clubs ingleses, en que los socios se reunían los jueves para comer, beber y sobre todo discutir y discurrir de todo lo opinable. Encargado Moratín de componer los estatutos del Club, por haber sido anteriormente nombrado Secretario de la Comisión correspondiente (15-XI-1792), el madrileño revela insospechados dotes de organizador, pues la semana siguiente presenta el fruto de sus meditaciones: "Cum Lugo, legi ad Comisión estatutos, placuerunt". Placuerunt, sí, pero no a todo el mundo, pues el 27-XI nota D. Leandro: "Cum Lugo y Gimbernat Chez Sames: disputas super estatutos". Es que el asunto no carecía de importancia: los estatutos de la nueva entidad habían de someterse a la aprobación de las autoridades británicas. A pesar del satisfecit que en un principio algunos dieron al secretario, había descontentos: "Gruñimientos de Nava y Cadalso ${ }^{3}$ propter lista envoyée ad Ministro" (14-2-93). En esas reuniones del Club, se propalaban noticias locales o generales, y el canario no es el último en traer nuevas: "Lugo dixit insurrección ex Marins Turtlintes" (17-2-93). Otras veces, las discusiones eran filológicas: "Club Hispanus: disputavi cum Gimbernat super dialectus catalaunicus" (es decir, sobre el catalán) (20-12-92).

Así y todo, la "cuestión palpitante" del Club Hispanicus no queda zanjada y vuelve a surgir periódicamente, como hoy día la de la existencia del monstruo del Loch Ness: "Nueva lectura y discusión de los estatutos" el 6 de diciembre de 1792. El 7 de febrero de 1793, ¡Albricias! se enteran los socios de la "aprobatio Regis ad Estatutos ex Club". Pero el 25 de abril, se produce otro incidente: "Club Hispanus. Cum Gimbernat. Magna disputatio cum Lugo. Legí actas del 4 y 11 , reformas in hora".

Sin más problemas que la vidriosa puesta a punto de los estatutos del Club, la vida corría agradable para los dos pensionados del gobierno español. Vivían a su aire, ningún interventor venía a fiscalizar el uso que hacían de las cantidades que les abonaba el Erario. Podían emplear su tiempo como Dios, o el Diablo - personalmente, en ocasiones, apostaría por el Diablo- les daba a entender, y nadie les impedía hacer de su capa un sayo, e incluso quitarse el sayo.

En efecto, además de las visitas que llamaríamos hoy en día turísticas a los monumentos de la capital británica, o de las visitas de cortesía —o interesadas-

3. Primo o sobrino del autor de las Cartas marruecas. Véase Cadalso, 1979, págs. 178-182. 
a personalidades o amigos, se ve en el Diario que Moratín y su cómplice llamaban con alguna frecuencia a la puerta de ciertas casas hospitalarias en que moraban unas señoritas acogedoras y moderadamente recatadas con las cuales les gustaba alternar.

Aunque su biógrafo Silvela dice que D. Leandro era "sobrio en los placeres"; aunque Hartzenbuch, al publicar sus Cartas, expurga púdicamente, tijeras en mano, su correspondencia, sabemos tanto por el Diario como por el copioso y sabroso epistolario de Moratín que conserva la Biblioteca Nacional de Madrid y que René Andioc publicó in extenso, que Moratín no vivía exactamente como un ermitaño. Si bien cobraba las rentas - modestas- de un beneficio eclesiástico; si, en los días de precepto iba a misa, hecho que consigna en sus apuntes, eso no le impide dejarse llevar por la sensualidad, que al parecer tiene muy viva. "Sus relaciones en Madrid con "la Mahonesa" -cuyo nombre aparece a menudo al principio del Diario - no tienen nada de platónico" escriben R. y M. Andioc (pág. 19 de su edición) ${ }^{4}$. Y cuando viaja, D. Leandro busca y halla sustitutas a la Mahonesa. En los dos meses que pasa en Burdeos (19 de mayo a 19 de julio de 1792) va dieciséis veces "chez catins", "chez putas", "chez quaedam meretrix"; incluso participa con su amigo Chabaneau en una orgía con dos mujeres, según confesión propia: "Orgie; illa alteraque nudae lussimis".

Del 25 de julio al 20 de agosto, reside en París; y en la capital francesa, cuyo populacho se entrega a sus instintos sanguinarios, Moratín sólo experimenta una emoción, fuerte por cierto, que arrolla todas las demás y todos los deseos: el miedo, un miedo pánico: "Ego pavor; ... têtes in lanzas, pavor". Emoción violenta que perdudará por otros motivos, durante la travesía del Canal de la Mancha: "Embarquéme in Paquebot, pavor terribilis" (26 de agosto de 1792).

Pero en la paz de Londres, ciudad civilizada, donde la gente no solía pasear cabezas cortadas al extremo de unas lanzas, lejos ya de las salvajadas revolucionarias, recobra la serenidad, y con ella la cachondez, y reanuda sus visitas a las heteras, visitas que va apuntando conscienzudamente, como acostumbra. Mas, - ¿será secuela del pánico que le causó el Terror, o consecuencia del "frigus" londinense que varias veces denuncia, o efecto de una baja de vitalidad? - en casi un año que pasó en Londres, solamente dieciocho veces alude a esas señoras, cifra muy baja comparada con las noventa visitas o más que el ritmo de su actividad en Burdeos parecía pronosticar. Y por si esto fuera poco, el madrileño se contentaba a veces con hablar con esas pelanduscas: "putas loqui", sin duda para mejorar su inglés!

4. En efecto, véase el 10-IV-1792: "Chez Mahonesa, futtui; optime”. (pág. 78). 
A menudo, en esas expediciones, le acompañaba Gimbernat, quien conservaba su libertad de acción: cierto día Moratín se contenta con beber: "ego vinum"; pero su compañero se queda "ad futtutionem" (sic). Al parecer, José de Lugo no participaba en esas bacanales. Sólo en una ocasión el nombre del canario está asociado al del madrileño y al del catalán. Pero en realidad se trata de una expedición frustrada, el 23 de noviembre de 1792: "Chez Gimbernat, cum il, Lugo, etc. in Sablonière manger; cum ils, in coche, buscar quaedam meretrix, sed non invenimus; café; cum il in Queen Street, bayle meretricio, sed horridae". No parece que Lugo acompañara a Moratín en sus múltiples andanzas mujeriles, ni siquiera en alguna de ellas".

Y tuvo razón. Pues el mismo Diario nos recuerda que el trato de esas amables amazonas entrañaba un peligro cierto. Un tal Locktón -o Loctóncomensal ocasional de los dos españoles, acompañó a Moratín y Gimbernat en una de esas salidas. A las pocas semanas, éstos se enteraron de que su compañero de juerga tenía que guardar casa y cama porque padecía lúe venérea, o sea sífilis. Afortunadamente, los galenos londinenses hubieron de hacerle una cura eficaz, puesto que, al cabo de un par de meses, el enfermo ya estaba en la calle y se reunía con sus amigos.

Así, gracias a los detalles que, pacientemente, fue apuntando Leandro de Moratín en su Diario, no incurriremos en el error de imaginar a José de Lugo viviendo solitario y totalmente aislado en medio de los ingleses en la capital británica. El Diario nos revela que existía en Londres durante la Revolución francesa una colonia española relativamente numerosa, activa, incluso algo bulliciosa, cuyos componentes se ocupaban afanosamente de sus negocios, como lo hacía el propio Lugo. Esos españoles, diplomáticos o comerciantes, pensionados por el gobierno español o estudiantes, intelectuales o artesanos, que debían de hablar inglés más o menos de corrido, participaban en la vida social inglesa, frecuentaban los restaurantes, los cafés, los lugares de reunión, las salas de fiesta, los espectáculos en boga y otros establecimientos públicos. Gente con algunas preocupaciones turísticas antes de la letra, ávidas de visitar monumentos, museos, puertos, de frecuentar bailes, teatros y demás espectáculos como la "linterna mágica", en una palabra gente deseosa de ver y comprender un país que para ellos era "diferente".

Pero esos visitantes de Inglaterra eran españoles y no se podían desprender ni a veinticinco tirones de su españolidad. Formaban un grupo bullicioso que había traído consigo de la terruña el gusto por las tertulias, las discusiones de sobremesa, las "piñas" o las "peñas", que allí, para sacrificar a la moda local, llamaban "Club"; un grupo que no quería fundirse ni confundirse con los nativos, sino que mantenía viva su diferencia nacional, e incluso, hacía alarde de su calidad de celtíberos y de su españolismo. Una sociedad en suma que 
prefiguraba ya la que formarían un cuarto de siglo más tarde los liberales españoles exiliados, sociedad que describiría con talento en Liberales y Románticos el profesor Vicente Llorens.

\section{BIBLIOGRAFÍA}

CADALSO, José. 1979. Epistolario, ed. Nigel GLENDINNING, Londres, Tamesis.

DEMERSON, Jorge. 1985. "Cadalso y el secreto". Coloquio Internacional sobre José Cadalso (Bolonia Oct. 1982), Abano Terme, Piòvan, págs. 79-104.

- 1988a. Un diplomático y hombre de negocios canario, D. José de Lugo-Viña, La Laguna, Instituto Estudios Canarios, págs. 13-16.

-. 1988b. "un diplomático canario pionero de la lexicografía provincial: Sebastián de Lugo-Viña y Massieu", Anales de Literatura Española VI, págs. 181-203.

FERNÁNDEZ DE MORATÍN, Leandro. 1967. Diario, ed. René \& Mireille ANDIOC, Madrid, Castalia. 


\title{
EL NIÑO DE LA BOLA Y LA FISIOLOGÍA DE LA NOVELA DECIMONÓNICA (II) *
}

\author{
Eva F. FLORENSA \\ University of Pennsylvania
}

\section{La "Novela Contemporánea" y el análisis de caracteres}

Cuando Don Trajano Mirabel está relatando a Luisita lo que nosotros hemos leído en resumen de la mano de Leopoldo Alas, la esposa del moratinista -al oír la palabra "adulterio"-_ se exalta:

¡Mirabel!... ¡yo no te he oído nunca hablar así! -interrumpió doña Tecla - ¡Esto pasa ya de castaño oscuro! (Alarcón, 1880, pág. 183).

Y el seguidor de Moratín le replica:

Porque nunca he tenido que hablarte de psicología ni de fisiología... —respondió el académico-. Pero la marquesa me comprende... (ibíd.).

¡En 1840 (momento en que se desarrolla la acción de la obra) un moratiniano afirma estar haciendo "estudios" (ibíd., pág. 184) de psicología y de fisiología! ¿Es éste un anacronismo por parte de Don Pedro A. de Alarcón? No.

El historial clínico de Manuel Venegas y de Soledad son — sin lugar a dudas- dos perfectas construcciones psicológicas pormenorizadas. En este hecho, no se separa el novelista andaluz de otros trabajos análogos que hicieran en 1881 Don Benito Pérez Galdós alrededor de Isidora Rufete (La deshereda$d a$ ) o en 1883-1885 Leopoldo Alas con su heroína, Doña Ana Ozores ( $L a R e-$ genta), estudios psicológicos —estos últimos—que se han venido considerando por parte de la crítica como naturalistas o, por lo menos, indudablemente realistas. En tales análisis, los períodos de la infancia y de la juventud son determinantes de la personalidad que el individuo poseerá en su madurez.

* Continuación de lo publicado en nuestro número anterior. 
Leopoldo Alas reconocía esta ley incluso cuando diseccionaba el carácter de alguno de sus contemporáneos; así, en su folleto titulado Benito Pérez Galdós, afirmó: "Soy de los que opinan que en la historia de los hombres la de su infancia y adolescencia importa mucho" (Alas, 1889, pág. 11). Con este criterio, era lógico que, en La Regenta, "Clarín" explicase durante hojas y hojas el origen social de la madre de Ana, la procedencia y el carácter de su padre, la educación liberal que éste le dio, la pronta orfandad de la niña, y el nuevo tipo de instrucción a que la sometieron sus tías, las nuevas tutoras. Para Leopoldo Alas, todas estas circunstancias que acabo de enumerar determinaron física y psicológicamente a la Regenta.

Un historial clínico realista-naturalista se complementaba con otro condicionante básico de la personalidad, la herencia. La locura de Isidora Rufete tiene sus precedentes en su padre y su hermano; las elucubraciones poético-espirituales de Ana Ozores hunden sus raíces, según sus propias tías, en el legado genético de su madre ' . Don Pedro A. de Alarcón coincide con Leopoldo Alas y Benito Pérez Galdós, pues, en El Niño de la Bola, se afirma expresamente este tipo de determinismo en la figura de Manuel Venegas al decir de él que su progenitor fue "descendiente, según dicen, de príncipes moros, cuya pícara sangre se le conoce bien a este chico en medio de sus buenos sentimientos" (Alarcón, 1880, pág. 25). De su padre hereda Manuel su heroísmo ("El alma heroica que heredara de su padre" [ibíd., págs. 102-103]), la fantasía ("fogosa y pertinaz imaginación" [ibíd. pág. 72]) y su destino trágico. Así pues, la personalidad del joven Venegas debe incluir también para su total cuadro clínico el factor de la herencia.

Conviene detenerse aquí para valorar la significación del análisis de psicología y de físiología que se realiza en torno a Soledad y a Manuel Venegas en El Niño de la Bola. La novela, como sabemos, se publicó en 1880. A juzgar por la importancia otorgada a la herencia y las circunstancias de la niñez y juventud de los dos protagonistas de la obra, la técnica de construcción de personajes de Don Pedro Antonio se emparenta directamente con la de Pérez Galdós y Alas. ¿Significa esto que el estudio de caracteres en la novela es un rasgo del realismo de la segunda mitad del siglo XIX?; dicho en otros términos, ¿la reconstrucción detallado-realista de una personalidad es una técnica propia de la nueva manera de novelar iniciada en España por Don Benito Pérez Galdós hacia 1870 ?

1. A esta conclusión llegan las tías a través de las informaciones que les ha ido aportando Doña Camila, la institutriz de Ana durante su infancia. Por su parte, el narrador es muy consciente de la importancia que las circunstancias de su niñez han tenido en la joven Ozores, pero parece dudar de la credibilidad de la interpretación determinista-hereditaria de Doña Camila y las tías (Alas, 1981, vol. I, págs. 193 y 232). 
Los más destacados críticos de la centuria pasada ("Clarín”, Rafael Altamira, Armando Palacio Valdés, etc.) contestaron afirmativamente a mis preguntas anteriores. Para ellos, el análisis de caracteres —un elemento que entendían como básico para toda buena novela - fue una innovación posterior a La Gloriosa (1868). Los más tradicionalistas (Benito Pérez Galdós, Emilia Pardo Bazán, etc.) lo retrotrajeron a Böhl de Faber y Mesonero Romanos. La dirección crítica que triunfó fue la de los primeros y, desde entonces, la novela contemporánea española comienza con La Gloriosa y, concretamente, con Don Benito Pérez Galdós.

José Alcalá Galiano, en su artículo "La fontana de oro", afirmaba lo siguiente, en 1871, sobre el arte de novelar de Don Benito: "Sólo la novela contemporánea puede, en efecto, hacer el análisis del alma humana" (Alcalá Galiano, 1871, pág. 152). También Armando Palacio Valdés, en artículo de 1878 titulado "D. Benito Pérez Galdós", reconoce en éste la calidad de pintor del estado mental o psicológico de sus personajes, hablando de que le caracteriza "un realismo espiritual e interior" y de que usa su pluma para "pintar al detalle y con admirable penetración, los más íntimos, los más yagos y confusos sentimientos del espíritu" (Palacio Valdés, 1878b, pág. 338).

Don Pedro A. de Alarcón, sin embargo, no estaba de acuerdo con aquellos de sus contemporáneos que iniciaban todo con La Gloriosa, e, incluso, iba más allá en la búsqueda de los orígenes del realismo que Doña Emilia y Don Benito. El análisis de caracteres - todos, librepensadores y críticos tradicionalistas, están de acuerdo- es el pilar fundamental del realismo en la novela. En El Niño de la Bola, una narración que sitúa su tiempo histórico en el año de 1840, hay un personaje, seguidor de Leandro Fernández de Moratín en lo artístico, afrancesado en su juventud política, y miembro de una sociedad secreta llamada "Jovellanos" (Alarcón, 1880, pág. 156), que realiza con la personalidad de la "Dolorosa" lo que él llama "estudios" (ibíd., pág. 184) "de psicología" y "de fisiología" (ibíd., pág. 183). Estas "autopsias morales"2 de Soledad, ¿son un anacronismo por parte de Alarcón? Ni mucho menos y, antes, todo lo contrario. Don Pedro Antonio sabía muy bien que los "estudios" "de psicología" y "de fisiología" existieron ya en la época de la niñez y juventud de Don Trajano Mirabel, es decir, hacia 1780.

En 1978, Rusell P. Sebold demostró en el "Prólogo" a su edición de $E l$ señorito mimado. La señorita malcriada, de Tomás de Iriarte, y en el artículo "Historia clínica de Clara: La mogigata de Moratín", que estos dos autores habían dibujado sus personajes siguiendo una idea propia del siglo ilustrado: el

2. Estos términos son una variante introducida, sólo, en la revisión que D. Pedro Antonio realizara de El Niño de la Bola para sus Obras (Alarcón, 1884, pág. 186). No aparecen en las tres primeras ediciones de la novela. 
medio en que se vive la niñez y juventud (familia y educación) condiciona la personalidad del individuo en su madurez ${ }^{3}$. Don Mariano, en El señorito mimado (1787), es un joven superficial y de pésima conducta por causa de la ineptitud de su madre como educadora; Doña Pepita, en La señorita malcriada (1788), es una petimetra que refleja en su persona los defectos nocivos de un padre juerguista y alocado; finalmente, en La mogigata (1791), la hipocresía de la hija no tiene otra causa que la gran hipocresía de su progenitor. Por otra parte, Sebold señalaba también en sus trabajos cómo en todas estas comedias existe un personaje alienista que descubre al público el origen de la enfermedad psicológica de los jóvenes (Don Cristóbal, Doña Clara y Don Luis, en El señorito mimado, La señorita malcriada y La mogigata, respectivamente).

En El Niño de la Bola, Don Trajano, educado en los principios de la Ilustración, era el único que podía comprender y analizar la psicología de la "Dolorosa". Él es el personaje alienista de nuestra novela. Su filiación moratiniana, además, nos informa de que Don Pedro Antonio tenía del pasado literario español un mejor conocimiento que José Alcalá Galiano, Leopoldo Alas o Armando Palacio Valdés al reconocer que el estudio pormenorizado de los caracteres va muchísimo más allá de la novela nacida con La Gloriosa. Este hecho histórico-literario permite dibujar una línea que comunica directamente el Realismo de la segunda mitad del siglo XIX con las bases intelectuales y la literatura del siglo XVIII: el análisis físico-psíquico de los personajes literarios no es una innovación de la novela decimonónica (ni de la primera ni de la segunda mitad del siglo XIX), es un resto en este siglo de las letras ilustradas. Tal aserción destruye la "novedad" de uno de los pilares básicos de la novela realista (el estudio de caracteres) en favor de un retroceso de sus orígenes en más de cien años.

Pero, ¿no pudo acontecer que, tras la literatura ilustrada, se perdiesen los análisis físico-psíquicos de los personajes de manera que en la novela realista éstos sí fueran una novedad?

José Alcalá Galiano, en su artículo anteriormente aludido, parecía sugerir una respuesta positiva a esta pregunta cuando, en relación a la novela histórica de la primera mitad del siglo XIX, afirmó: "y cuyos personajes no nos ofrecen más que la exterioridad de sus actos sin que podamos penetrar los recónditos senos de su conciencia" (op. cit., pág. 152). Sin embargo, otro artículo de Armando Palacio Valdés, "D. Francisco Navarro Villoslada”, permite puntualizar

3. Russell P. Sebold demuestra esta base intelectual ilustrada, no sólo en el Prólogo a $E l$ señorito mimado. La señorita malcriada y en "Historia clínica de Clara: La mogigata de Moratín", sino también en la producción novelística dieciochesca, concretamente en su estudio preliminar a Fray Gerundio de Campazas de José Francisco de Isla. 
lo que, en boca de Alcalá Galiano, se interpretaba como una negación del análisis de caracteres en la novela histórica romántica. Comienza el crítico afirmando que "la novela histórica" falsea la "descripción más o menos fiel de [...] sentimientos de un período histórico" (Palacio Valdés, 1878a, pág. 712) porque "insensiblemente, sin que el artista lo perciba, y a despecho de todos sus escrúpulos y pruritos de veracidad, se introduce en la obra el acento moderno y se enseñorea de ella" (ibíd., pág. 713). Con gran humor dice Don Armando que, en la novelística histórica, el mundo psicológico subyacente bajo el medievo o la época de los austrias es el romántico trasnochado. Es decir, Palacio Valdés rechaza aquel tipo de novela en que, "al penetrar en una sala gótica" (ibíd.), halla allí "al vecino del cuarto tercero" que es "persona muy honrada, de continente grave y hasta cierto punto melancólico" (ibíd.). El crítico niega esta forma novelística romántica ("la novela arqueológica no es viable como género literario" [ibíd.]) por cuanto no guarda decoro entre el momento histórico que describe y el universo psíquico de los personajes que lo pueblan. Sin lugar a duda, para Palacio Valdés, éste era un grave atentado contra la verdad o "realismo", pero él mismo (cuando se preocupaba únicamente de lo literario, y no caía en sus prejuicios políticos de pensador liberal) nunca pudo considerarlo una negación del análisis de caracteres por parte de la novela histórica. A confirmar mi último aserto acude otro de sus artículos dedicado a "D. Manuel Fernández y González". En él, incluye "la pintura de los caracteres" como uno de los componentes, junto a "la descripción de costumbres" y "la verosimilitud de la fábula" (Palacio Valdés, 1878c, pág. 661), de la novela histórica. Además, comentando la manera de novelar de Fernández y González, acaba diciendo Don Armando que éste "es más realista de la Edad Media que su maestro Walter Scott" (ibíd., pág. 660. Subrayado de Palacio Valdés) porque mientras el último dibujaba a su Ivanhoe "con ese tinte suave y melancólico" (ibíd.), el novelista español "penetra por la coraza damasquina y la recia cota de malla, y sorprende los sentimientos de aquellos corazones tan rudos e independientes" (ibid.).

Así pues, toda "novela arqueológica" poseía estudio de caracteres, aunque éste, comparado con su marco histórico, era corrientemente anti-"realista". Sólo unos pocos (Fernández y González, según Armando Palacio Valdés) lograron el éxito en la ardua tarea de reconstrucción de la novela histórica, los más cometieron el anacronismo de dotar con un perfecto estudio de la psique romántica a hombres que vestían "coraza damasquina" y "recia cota de malla". Es decir, la novela del Romanticismo, desde el punto de vista de la psicología de sus personajes, era "realista" en relación al universo psíquico de la época en que la escribían sus autores, pero totalmente anti-"realista" (verbigracia, "idealista", según término de la época) con respecto al contenido mental del momento histórico en que ocurría la acción de la obra. Conscientes de este 
problema, los hombres del Realismo decidieron abandonar el pasado y acudir al presente, del cual podían escudriñar su marco histórico y sus psicologías sin anacronismo alguno. Así Armando Palacio Valdés afirmaba que "todas las personas de cierta categoría literaria están conformes en que ... los sentimientos que se pinten, han de ser ... los sentimientos contemporáneos" y que cuando se quisiera conocer los de otra época se acudiese a las crónicas, a las memorias o a las letras de aquel momento, nunca a las producciones novelísticas del Romanticismo (Palacio Valdés, 1878a, pág. 173)

No sólo coinciden las comedias de costumbres, la novela histórica y la novela de la segunda mitad del siglo XIX en el estudio de caracteres, sino también en la base filosófico-científica en que éste se apoyaba. Hemos visto cómo El señorito mimado, La señorita malcriada o La mogigata respondían, en la elaboración de la psique de sus protagonistas, a la idea dieciochesca de que el medio configura la personalidad de un individuo. Vimos cómo éste era también el sustento ideológico de la construcción de los caracteres en La desheredada, La Regenta o en El Niño de la Bola. Mi tesis quedaría incompleta si no señalase la continuidad de este principio en la novela histórica de la primera mitad del siglo XIX. De ser esto posible, aparece en la historia de la literatura un nuevo lazo que une las letras del XVIII con las de su inmediato próximo, y que -destruyendo la incomprensión de la crítica del siglo XX y evidenciando el manejo interpretativo que algunos de los críticos posteriores a La Gloriosa hicieron de su pasado inmediato- acerca estrechamente la novela histórica romántica a la novela realista de la segunda mitad del XIX.

A pesar de que la construcción de caracteres apenas se ha estudiado en la novelística del Romanticismo, contamos, sin embargo, con unas breves anotaciones de Russell P. Sebold que abren el inmenso campo existente en la novela romántica para aquéllos interesados en este tipo de análisis. En un corto artículo de 1988, el ilustre filólogo norteamericano apunta la relación presente entre el estudio de caracteres de la novela romántica y el del Realismo. Hablando de Kerima, la protagonista de El moro expósito (1834), novela histórica en verso del Duque de Rivas, dice que el "estudio clínico" realizado sobre ella "se anticipa a los análisis patológicos de personajes femeninos de

4. Las mismas ideas había expresado treinta años antes Ramón de Navarrete. Definía la novela histórica como "una narración más o menos fiel, más o menos exacta, de sucesos pretéritos" (Navarrete, 1847, pág. 83), pero no consideraba que ella cumpliese con la que a su juicio era la finalidad de toda novela ("ilustrar a la generación presente en lo que es relativo a sus vicios propios, a sus instintos y a las leyes que la mueven y la gobiernan" (ibíd.). Según Navarrete, dichos objetivos sólo se alcanzarían si nuestros novelistas imitaban lo que se hizo en el pasado ("Casi todos los escritores antiguos, al escoger época para sus obras, hacíanlo en la suya propia" (ibid.). Por lo tanto, concluye el crítico que, entre las modalidades novelísticas discutidas, los hombres de letras del momento deben "preferir la novela contemporánea [v. g., "novela de costumbres contemporáneas"] a la novela histórica" (ibid.). 
novelas decimonónicas posteriores, como Madame Bovary y La Regenta" (Sebold, 1988, pág. 72). El profesor norteamericáno no olvida mencionar que éste no es un caso aislado en la primera mitad del siglo XIX ya que el mismo tipo de construcción e idea subyace bajo "la historia clínica de la tuberculosis y la ansiedad de separación de Beatriz en El señor de Bembibre (1844) de Enrique Gil y Carrasco" (ibid.). Y, acto seguido, Sebold pasa a desarrollar el análisis del carácter de Kerima que el "alienista", Angel Saavedra, dictamina en El moro expósito: la decisión de la joven, al final de la novela, de profesar está racionalmente explicada y justificada a través de una historia clínica en la que el medio juega un papel determinante ("Su sufrimiento y la imposibilidad de sus amores son de su propia fabricación, bajo la influencia de su medio" [ibíd.]). Estudios del tipo realizado por Russell P. Sebold son un corrosivo de las fronteras que interpretaciones críticas prejuiciosas o desencaminadas han levantado entre las dos modalidades novelísticas del siglo XIX. Más adelante, en el presente artículo, veremos cómo dichos límites en la novela decimonónica caerán casi completamente para permitir el esbozo de un nuevo cuadro de la historia literaria del siglo en donde, antes que ruptura y diferencias entre el Romanticismo y el Realismo, se delinean semejanzas y lazos de continuidad histórica.

\section{La "Novela Contemporánea" y el estudio de costumbres}

A Doña Emilia Pardo Bazán le parecía, en su folleto Pedro Antonio de Alarcón (1891-1892), que la grandeza de El Niño de la Bola radicaba en su "color local andaluz" (Pardo Bazán, 1973, pág. 1397). Dijo la autora al respecto:

Que El Niño de la Bola es novela rara, hermosa, fuerte, bañada de luz meridional, étnica en el sentido más delicado de la palabra ... lo considero probado para todo el que lea ese precioso libro (ibíd., pág. 1396. Subrayado de Doña Emilia).

¿Qué significa que El Niño de la Bola sea una novela "étnica"?

Cada colectividad — pensaban los hombres del Realismo- posee una peculiar forma de pensar y de vivir dependiendo de su pasado histórico y de su sangre. Las artes, afirmaron estos mismos hombres, debían ser expresión y estudio de tal peculiarismo. Doña Emilia, en su folleto ya citado, plasma esta idea en forma definitiva:

No cada nación, sino cada raza de las que el nombre de nación unifica políticamente, sin lograr fundir la misteriosa diversidad y hasta oposición de sus sangres y de sus almas, tiene una poesía característica, modos de sentir, de soñar, de amar y de creer, que se revelan en momentos críticos, con belleza propia, íntima y penetrante. Esa poesía, 
que resplandece con fugitiva luz, el gran artista la sabe condensar en un libro, en un cuadro, en una estrofa (ibid.), págs. 1396-1397).

El concepto "raza" en el siglo XIX no era tan estrecho como el de la actualidad y se refería a todo grupo humano que participaba de unas mismas particularidades histórico-socio-culturales: los habitantes de un determinado territorio, una clase social, una ciudad, los individuos de una misma profesión, etc. Con esta idea de raza y con su compañera (las artes han de expresar dicho peculiarismo étnico) se escribió, por aquel entonces, la mejor literatura de todo el siglo XIX. Émile Zola analizaba en los Rougon-Macquart la "raza" parisina. Don Benito Pérez Galdós, en 1870, aconsejó ${ }^{5}$ que la novela española contemporánea estudiase la "raza" madrileña (Pérez Galdós, 1870, pág. 166). Con su vocabulario krausista y asimilando el concepto "raza" al de "nación", Leopoldo Alas divulgaba también este mismo principio mental. En su fclleto Benito Pérez Galdós dice que el novelista canario, en sus creaciones literarias, tiene la finalidad "de escribir la historia novelesca de nuestra epopeya nacional del presente siglo" (Alas, 1889, pág. 26. Subrayado mío). Para interpretar correctamente a "Clarín" debe saberse que él y otros krausistas entendían la "epopeya" como un vasto panorama literario de las instituciones, las costumbres y la cultura general de un pueblo o colectividad que sirve para definir su carácter. Don Francisco Giner de los Ríos, en 1864, lo expresó así: "Por esto son las epopeyas, al par que inextinguibles tesoros de bellezas inmortales, precioso arsenal de datos para el historiador y como la muestra más espontánea y evidente que da de sí y de su genio un pueblo" (Giner de los Ríos, [1864] 1969 , pág. 57). Y voy a hacer mención aquí, para perfilar completamente el alcance de esta idea, que Leopoldo Alas, en Apolo en Pafos (1887), afirma que "la novela es la épica del siglo" (Beser, 1972, pág. 30. Subrayado del autor) y también "un modo de historia de la actualidad" (ibid., pág. 33).

Como puede verse, los términos que usan estos novelistas y críticos refiriéndose a la descripción realista que la novela hace de "modos de sentir, de soñar, de amar y de creer" de un grupo humano concreto o "raza" son muy variados. Balzac habló de "physiologie" y Émile Zola de "histoire", Doña Emilia Pardo Bazán de "novela étnica", Leopoldo Alas y Francisco Giner de "épica" o "epopeya nacional", sin embargo, todos ellos se referían a lo que genéricamente se calificaba como "la novela moderna de costumbres" (Pérez Galdós, 1870, pág. 167).

5. Pérez Galdós fue aconsejando lo mismo a lo largo de toda su vida. En dos de sus mejores artículos, ambos de 1897, "La sociedad presente como materia novelable" y "José María de Pereda, escritor" (Pérez Galdós, [1897] 1972, págs. 173-182 y 189-204, respectivamente), el novelista canario reincide en la idea de que la novela debe ser expresión del estado mental y ambiental de la colectividad concreta que el autor estudie.

6. El subtítulo "histoire" ("fisiología") de Les Rougon-Macquart fue utilizado también por Galdós, quien subtituló: "Dos historias de casadas" su Fortunata y Jacinta. 
Si el estudio pormenorizado-realista de caracteres se consideró una de las bases de la recién nacida novela española tras La Gloriosa, el estudio pormenorizado-realista de las costumbres era, según los hombres de la segunda mitad del siglo XIX español, el otro pilar de la nueva novela. Pero, ¿en qué consistía exactamente un análisis minucioso-realista de costumbres?

Los personajes - como instrumentos para la expresión de "modos de sentir, de soñar, de amar y de creer"- se convirtieron en la novela del Realismo en "tipos". Afirmar este hecho no significa suprimir al estudio de caracteres su profundidad, sino todo lo contrario, ya que éstos se construían como directamente determinados por su ámbito vital (herencia, familia y cultura), es decir, por los "modos de sentir, de soñar, de amar y de creer" que les rodeaban. En otros términos, el siglo XIX descubrió que una personalidad - por cuanto se origina condicionada por las circunstancias de su alrededorse convierte en reflejo, y por tanto, símbolo, de ellas. Este es el contenido mental subyacente bajo el concepto "tipo" de la crítica y de la literatura decimonona ${ }^{7}$.

El mismo medio ambiente en que se desarrollaba una personalidad (modos de educar, costumbres familiares, religiosas y sociales, etc.) reflejo realista del momento histórico- era también propia del Costumbrismo. Así pues, Costumbrismo lo era todo para la narrativa novelística del siglo XIX. Lo fue la fiel descripción y análisis de los personajes y de su historia porque, como "tipos", representaban a los hombres del momento con todo su contenido mental y carga histórica. Lo fue también la fiel reproducción de la realidad socio-económica, política y cultural porque ése era el marco en que los individuos del XIX se habían formado y continuaban formándose como personalidades. Costumbrismo, repito, lo fue todo para la narrativa novelística posterior a La Gloriosa. Esta afirmación (que posiblemente escandalizará a la mayoría de críticos de mi época) no es mía, sin embargo. Luis Vidart, en un estudio sobre Un viaje de novios de Doña Emilia Pardo Bazán que tituló "El naturalismo en el arte literario y la novela de costumbres" (1882), defendía que "la novela de costumbres [es decir, Un viaje de novios], o es naturalista, o no es novela de costumbres" (Vidart, 1882, pág. 190). Al igual que casi todos sus coetáneos, Vidart se refiere a la novela moderna de su época con el término "novela de costumbres contemporáneas" (ibid., pág. 197). Es más, para él, Realismo y Naturalismo son técnicas científico-literarias o instrumentos para la construcción de una novela, pero no palabras que definan a la vez a éstos y la intención y contenido de una obra novelística (o sea, "el estado de la cultura contemporánea" [ibid.]), palabras que no pueden ser otras que "novela de costumbres".

7. Definía Andueza en 1845: "Tipo es un individuo de la sociedad que representa una clase a la cual convienen costumbres propias que de ningún modo pertenecen a otra alguna [...] en estos tipos está no sólo retratada la figura, sino el alma" (Montesinos, op. cit., pág. 111 ). 
Nadie es capaz de negar que El Niño de la Bola no sea una "novela de costumbres". Para quienes tengan una visión estrecha (a saber, de siglo XX) del Costumbrismo, podemos aducir dos "cuadros" de la obra: los episodios de la "rifa" (Alarcón, 1880, págs. 118-129 y 350-370) y el capítulo titulado "Dos retratos por vía de entremés (capítulo inútil, que pueden dejar de leer los impacientes)" (ibíd., págs. 160-171). Para los que hayan comprendido lo que andamos diciendo, será ya claro a esta altura de mi artículo que el estudio de las personalidades de Manuel Venegas y de la "Dolorosa" son Costumbrismo, y que desde luego, en El Niño de la Bola, hay toda una reconstrucción "costumbrista" de una ciudad provinciana de Sierra Morena en el año concreto de 1840. Ello significa que el análisis económico, social, de las tradiciones religiosas, educativas y literarias, de la política, etc. que existen en la novela de Don Pedro Antonio no es más que un "cuadro" (Alarcón, 1880, pág. 6) de los "modos de sentir, de soñar, de amar y de creer" de una urbe andaluza por los años en que triunfaba el Romanticismo.

Acabemos de perfilar la figura de Manuel Venegas como "tipo". Si El Niño de la Bola es una novela "étnica", tal como afirmaba Doña Emilia, entonces el joven debe ser reflejo "costumbrista" ("modos de sentir, de soñar, de amar y de creer" + realismo) de una personalidad arábigo-andaluza ${ }^{8}$.

Don Pedro Antonio inicia su capítulo II del Libro I, "Nuestro héroe", con una descripción pormenorizada de la imagen de Manuel Venegas. Describe su forma de vestir para terminar poniendo de relieve su "atavío semi-andaluz, semi-exótico" (ibíd., pág. 11). A continuación, comienza el retrato de su faz, señalando "sus africanos ojos" (ibíd., pág. 12). Pasa luego Don Pedro Antonio al cabello de Venegas y, algo más tarde, a su "fisionomía" (ibíd.), retratando "un perfil intachable, sirio más bien que griego... y, sobre todo, una barba negra, undosa, de sobrios aunque largos rizos, trasunto fiel de las nobles y celebradas barbas árabes y hebreas (ibid. Subrayados míos). Sin lugar a dudas, Alarcón era un buen discípulo de Johann Caspar Lavater ${ }^{9}$ ( $i 1741-1801$ !), quien, a través del estudio de las facciones del rostro, determinaba el carácter o psicología de

8. El siglo XIX concibió a Andalucía y Murcia como pueblos o "razas" moriscos, es decir, afectados por una gran impronta árabe, $\mathrm{D}$. Pedro Antonio a menudo se hizo eco de esta interpretación histórico-determinista. Sobre uno de sus propios parientes dijo: "Eran unos grandes ojos moriscos, llenos de luz y energía [...] Eran los ojos de mi primo, más semítico que jafético" (Alpujarra $, \mathrm{V}, \mathrm{i})$. En torno a tío Lucas escribió: "Vamos... Vamos a descambiar, díjole el murciano a don Eugenio, alegrándose mucho de no haberlo asesinado, pero mirándolo todavía con un odio verdaderamente morisco" (El sombrero de ires picos, XXXIII). Finalmente, en La Pródiga, II, xiii dejó clara la idéntica filiación étnica de andaluces y murcianos: “¿Estos andaluces!... -Murciano, señor conde... -Viene a ser lo mismo".

9. Quienes estén interesados en la "Fisiognomía", en Lavater y en el influjo de aquélla en la literatura europea, pueden acudir a Graeme Tytler, Physiognomy in the European Novel, Faces and Fortunes. 
un individuo. Por medio del análisis "fisiognómico" de Manuel Venegas, Don Pedro Antonio dictamina que el Niño de la Bola es una completa personalidad romántica, no sólo por la educación rusoniana que recibió, sino también porque su "raza" semita le convertía en un campo abonado para que germinara con total éxito la semilla del Romanticismo. La "fisonomía" morisca que dibuja Alarcón va acompañada, pues, de su "psicología" y así el "cuadro" de la personalidad del joven se completa con el análisis de las aportaciones de la sangre árabe en el carácter de Manuel Venegas, romántico por Rousseau y por su raza.

El Niño de la Bola era "descendiente del Profeta Mahoma" (Alarcón, 1880, pág. 27), tal herencia sanguínea aporta a su carácter dos rasgos característicos de su etnia: el heroísmo ("El alma heroica que heredara de su padre" [ibíd., pág. 102-103]) y una excesiva y peligrosa fantasía ("fogosa y pertinaz imaginación" [ibíd., pág. 72]). Estos dos elementos semitas de su personalidad, de los cuales participan todos sus conciudadanos ("su morisca imaginación [de las gentes de la urbe andaluza], ganosa de emociones extraordinarias" [ibíd., pág. $352]$ ), le convierten en un joven que, ya que vive de 1813 a 1840, irremediable y hereditariamente ha de ser un hombre romántico y àrrastrado hacia la tragedia, al igual que el determinismo de su sangre y de su educación filantrópico-ilustrada llevó a Don Rodrigo Venegas a su muerte.

Si el Niño de la Bola es un "tipo" "costumbrista", ¿cuántos Manuel Venegas no habría en las ciudades andaluzas hacia 1840 ? Pensemos por un instante. Los convecinos de la "Dolorosa" interpretan, sin serlo, la personalidad de la joven como la de una heroína de novela. ¿No sería que ellos eran los verdaderos caracteres románticos? Después de todo, la sangre de la hija de Don Elías tenía poquísimo de semita (ya que por lo menos su padre era de La Rioja) mientras que a la que sin duda pertenecían los vecinos de Soledad era a la "raza" arábigo-andaluza. A través de su obra, Don Pedro Antonio de Alarcón nos explica que Andalucía (debido especialmente al heroísmo, así como a la imaginación y fantasía, propios de su etnia) fue pasto precioso del Romanticismo. El propio novelista es un buen ejemplo de lo dicho, por lo menos bajo interpretación de sus contemporáneos ${ }^{10}$.

10. Doña Emilia Pardo Bazán, en el folleto que dedicó a nuestro autor (op. cit.), apunta repetidamente la conexión entre la sangre semita de Don Pedro Antonio y su romanticismo y liberalismo juveniles, exaltados primero y calmados en su madurez:

Pero notemos también lo impresionable del temperamento de Alarcón, lo crespo y alborotado de su alma semita (pág. 1366),

pues Alarcón no era revolucionario, ... pero tenía en su alma el calor y la inquietud propios de los hijos del Mediodía... (pág. 1367).

Esta es la primera parte del análisis de la novelista gallega ya que, al igual que Don Pedro Antonio con el Niño de la Bola, ella realiza una completa "fisiognomía" del autor andaluz y, así, junto a su caracterización psicológica, dibuja Doña Emilia la descripción física del literato: 
La reconstrucción "costumbrista" de El Niño de la Bola va más allá. Incluye el otro aspecto del "costumbrismo", el estudio pormenorizado de la economía, la sociedad, las tradiciones religiosas, educativas y literarias, la política, etc. de una urbe provinciana de Sierra Morena en los años próximos a 1840 .

Los personajes de El Niño de la Bola, como "tipos", resumen peculiares "modos de sentir, de soñar, de amar y de creer" de los habitantes de la Sierra, dependiendo de su edad y circunstancias vitales ("raza" y herencia, educación, familia, etc.). Tenemos el joven romántico, librepensador y ateo (Manuel Venegas), la jovencita mimada que todos creen romántica y, en realidad, sería una adúltera y materialista (la "Dolorosa"), tenemos a los hombres maduros educados en la Ilustración (Don Rodrigo Venegas y Don Trajano y sus amigos); frente a la joven provinciana (la "Dolorosa"), presenta Don Pedro Antonio a una forastera (Doña Luisita), exteriormente un ejemplo de romanticismo madrileño, pero en el fondo una materialista empedernida; frente al librepensador y ateo, aunque hombre bueno (Manuel Venegas), existe otro joven de su misma edad, también librepensador y ateo, pero malo por naturaleza ("Vitriolo"); el "cuadro" se perfila con un santo obispo, "un cura de misa y olla" (Alarcón, 1880, pág. 45) representado por Don Trinidad Muley, una simple madre de familia (la señá María Josefa) y miles de "moriscos" y unos pocos "forasteros, procedentes de Santander, de Galicia, de Cataluña o de la Rioja" (ibíd., pág. 32).

Si se analiza El Niño de la Bola desde el punto de vista social, la novela es también un prodigio de reproducción de la economía y de la sociedad de dicha urbe de Sierra Morena en 1840. En el pasado, en tiempos de D. Carlos III (ibid., pág. 96), hubo intentos de explotación de las riquezas de la Sierra; hay en la ciudad algunos "hijosdalgo", unos ricos (el Marqués de Mirabel) y otros que perdieron su riqueza (Don Rodrigo); a estas tierras andaluzas han llegado "forasteros" que se convierten pronto en "todos los dignos comerciantes e industriales de las poblaciones de Andalucía, inclusas las capitales y aldeas" (ibíd., pág. 32), no hay mejores ejemplos de esto que el usurero "Caifás" (Don

Mirábale yo, y de moro le encontraba la figura: con aquella nariz algo curva, aquellos ojos hundidos, de azabache, aquella oriental barba, le sentarían a maravilla el turbante y el alquicel (págs. 1374-1375).

(Quien lea atentamente el capítulo de El Niño de la Bola titulado "Nuestro héroe", se sorprenderá del exacto parecido externo entre Manuel Venegas y su autor).

No sólo la Pardo Bazán reconoce la "raza" semita de Don Pedro Antonio, pues otro de sus contemporáneos, Don Manuel de la Revilla, realiza una "fisiognomía" muchísimo más completa del novelista andaluz (Revilla, 1883, págs. 91-100):

Ostentaba su fisonomía los trazos característicos de aquella generosa raza, y encerraba su espíritu todas las cualidades que la distinguieron: ardiente y soñadora fantasía, condición indómita y arrogante, corazón fogoso e hirviente en pasiones, ánimo dispuesto a todo linaje de temerarias aventuras y poderosos ataques (pág. 92).

(En esta ocasión, obsérvese el parecido psicológico entre el Niño de la Bola y su creador). 
Elías) o el industrial Don Antonio Arregui, padre y marido de Soledad respectivamente; y nos informa también Alarcón de que, en Madrid, cierta marquesita de vida romántica (Doña Luisa) derrocha con este tipo de existencia las últimas tierras que heredó y que se hallan en Sierra Morena; para completar el "cuadro" tenemos un militar en retiro que vive de su pobre pensión, un ayudante de botica ("Vitriolo"), varios secretarios de ayuntamiento, etc.

El estudio de El Niño de la Bola desde su reconstrucción política presenta el poder de la ciudad en manos de un "hijodalgo" rico (Don Trajano Mirabel), socorrido en sus funciones, posiblemente, por la inspiración del obispo de la urbe. Además, desde Madrid, personalidades políticas como Don Evaristo Pérez de Castro ("a la sazón Presidente del Consejo de Ministros" [ibíd., pág. 160]) y Salustino Olózaga (político y orador que vivió de 1805 a 1873 y que fue Presidente del Consejo (1843) y varias veces embajador en París) le mandan al señor de Mirabel cartas recomendándole a Doña Luisita, lo que prueba las buenas relaciones del "cacique" con hombres políticos de la Capital de España. tumbres"?

¿Quién puede negar que El Niño de la Bola no sea una "novela de cos-

La afirmación de este interrogante nos define la novela de Don Pedro Antonio como una obra de la segunda mitad del siglo XIX (a saber, del Realismo/Naturalismo) porque "novela de costumbres" era el nombre utilizado en la época para referirse a Fortunata y Jacinta, Un viaje de novios, Pepita Jiménez, La Regenta, La Montálvez, Pequeñeces, José, y etc., etc., etc. ¿Significa esto que el "costumbrismo" (el segundo pilar - iy básico!- de la novela posterior a La Gloriosa) es privativo de la "novela de costumbres"?

Ni mucho menos, ni tan siquiera del siglo XIX. Las raíces, de nuevo, hay que buscarlas en la Ilustración. Don Pedro Antonio descubre esta verdad histórica (todo el pensamiento decimonono tiene sus bases ideológicas en el Siglo de las Luces) por boca de uno de los amigos ilustrados del señor de Mirabel. Este último está maldiciendo a los románticos, librepensadores y ateos (es decir, a las coordenadas mentales más importantes del siglo XIX) y su amigo le replica:

- -Esas gentecilla que dices es nuestra legítima heredera!... Nosotros, con nuestros pergaminos y sangre azul, fuimos, cuando jóvenes, partidarios de la Razón, del Buen Sentido, y hasta de aquel Ser Supremo que substituyó al antiguo Jehová... ¿No te acuerdas? (ibíd., págs. 354-355. Subrayados de Don Pedro Antonio).

Si Don Trajano y sus amigos son discípulos de Moratín, en éste y en Tomás de Iriarte encontramos los mejores ejemplos de "costumbrismo" (descripción realista" + "el estado de la cultura contemporánea") del siglo XVIII. 
De nuevo ha sido Russell P. Sebold quien, en el Prólogo a su edición de $E l$ señorito mimado. La señorita malcriada y en su artículo "Historia clínica de Clara: La mogigata de Moratín", ya citados con anterioridad, desarrolla y explica el "realismo" (avant la lettre) y el estudio de costumbres de estas obras.

Algunos pueden objetarme, sin embargo, que estoy aduciendo textos "costumbristas" que no pertenecen al género de la novela. $O$ decirme que entre el teatro de costumbres contemporáneas del siglo XVIII y la novela posterior a La Gloriosa median más de cincuenta años. Pues bien, justamente en tal intermedio crecieron y se desarrollaron dos grandes manifestaciones "costumbristas", los artículos de costumbres y la novela histórica.

El "costumbrismo" en las colecciones de artículos de Mariano José de Larra, Ramón de Mesonero Romanos o de Serafín Estébanez Calderón no presenta problema alguno, a no ser que se me puede seguir objetando que éste no es un género novelístico.

Si pasamos a la novela histórica del Romanticismo, entonces la objeción es mayor ya que muchos no creerán que sea ésta una modalidad "costumbrista". Sin embargo, lo es, y así lo aceptaron incluso los críticos librepensadores de la segunda mitad del siglo XIX. Armando Palacio valdés, en artículo de 1878 ya citado, "D. Manuel Fernández y González", no sólo sabe que la novela histórica, desde el mismo Walter Scott, es "costumbrista", sino que cree que la elaborada por Fernández y González se caracteriza por un grado superior de "costumbrismo", pues "es más realista de la Edad Media que su maestro Walter Scott" (Palacio Valdés, 1878c, pág. 713. Subrayado del autor). El carácter "más realista" al que alude el crítico responde a que Manuel Fernández y González, frente a Walter Scott, se preocupa por "penetrar más adentro... en el mundo del espíritu" de la Edad Media mientras el novelista inglés se detiene sólo en la reproducción "realista" de sus "costumbres, sus trajes, su fisonomía exterior" (ibid.). Sea como sea, Palacio Valdés reconoce que, ya desde su mismo padre, la novela histórica tenía por finalidad "un estudio atento y minucioso" ( ibíd.) del escenario externo de un momento puntual de la Historia y que incluso algunos, como es el caso de Manuel Fernández y González, sumaron al análisis de la "fisonomía exterior" de un período pretérito el "cuadro" también "realista" de su particular psicología. Esos "algunos" fueron los menos. Por eso, el mismo Armando Palacio Valdés consideró en su "D. Francisco Navarro Villoslada", utilizado con anterioridad, "que la novela arqueológica no es viable como género literario" (Palacio Valdés, 1878a, pág. 713), y que "las costumbres y los sentimientos que se pinten, han de ser las costumbres y los sentimientos contemporáneos" (ibíd.). Sin embargo, la novela histórica continuó incluso en la segunda mitad del siglo XIX, teniendo como máximo cultivador a Don Benito Pérez Galdós. 
Si la "novela costumbrista" posterior a La Gloriosa es novela de caracteres (es decir, "tipos") y es novela de "costumbres", y la buena "novela arqueológica" ha de saber combinar también ambos rasgos ", ¿en qué se diferencian las dos formas novelísticas del siglo XIX? La clave nos la da Rafael Altamira y Crevea, en artículo titulado "Un drama de Galdós", sobre una adaptación teatral de El audaz: la "novela arqueológica" o histórica es un estudio de caracteres y de costumbres "en una retroacción artística de tiempos pasados" (Altamira y Crevea, 1921, pág. 63). Es decir, la única diferencia entre la novela de la primera mitad del XIX (Romanticismo) y de la segunda (Realismo/ Naturalismo) es que el análisis de "tipos" y "cuadros" tiene lugar, en aquélla, en un marco histórico pretérito, generalmente la Edad Media, mientras que, en la "novela de costumbres (contemporáneas)", la acción acontece en el momento histórico contemporáneo al autor.

Dibujadas así las cosas, el "costumbrismo" es una corriente estética (="realismo") y mental (= a la búsqueda del carácter o psicología de un pueblo o colectividad). Como movimiento, tuvo una larga vida. Recogió sus principios ideológicos y estéticos en la Ilustración, y se plasmó artísticamente en ese mismo siglo, llegando -fiel a sus bases originales- hasta fines de la centuria siguiente.

Volvamos a El Niño de la Bola. Sin lugar a dudas, es una novela "costumbrista". Pero, ¿es una "novela arqueológica", es decir, un estudio de las "costumbres" "en una retroacción artística de tiempos pasados", o es una típica "novela de costumbres (contemporáneas)"?

En 1870 se publicó en Madrid La fontana de oro, de Benito Pérez Galdós. Sobre ella decía José Alcalá Galiano, en Revista de España (1871), que se anunciaba "como novela histórica, y si bien tal título le corresponde por referirse y pintar hechos de nuestra historia de 1820 " asimismo "con no menor fundamento puede calificarse de novela de costumbres" (op. cit., pág. 150. Subrayados míos). Manuel de la Revilla, en su boceto literario sobre "D. Benito Pérez Galdós", aceptaba el mismo hecho en torno a La fontana de oro y El audaz: "Reconocióse lo feliz de la combinación de la novela histórica con la de costumbres" (Revilla, 1883, pág. 112). ¿Significaba esto que novelas como La fontana de oro (1870) o El audaz (1871) y los Episodios participan del mismo género que El doncel de don Enrique el doliente (1834) o El señor de Bembibre (1844)? Sí, aunque entre los dos grupos de novelas existe una pequeña diferencia; en las primeras se abandona "los heroicos tiempos de nuestra reconquista" y "de la dinastía austriaca" (Alcalá Galiano, 1871, pág. 152)

11. Así se desprende de las siguientes palabras de Alcalá Galiano (op. cit., pág. 154. Subrayados míos):

Walter Scott y en general los novelistas ingleses pecan, es verdad, de minuciosos, pero en cambio ¡qué tipos tan acabados, reales y perfectos!, ¡qué cuadros tan inimitables han creado! 
y elige una época intermedia que, sin tener el excesivo y peligroso realismo del momento presente, está lo suficiente remota para inspirar el interés de lo pasado, y bastante inmediata para relacionarse con el presente y pintar la realidad (ibid.)

Es decir, la novela histórica de la segunda mitad del siglo XIX acerca el tiempo de su acción cada vez más a la época contemporánea.

El Niño de la Bola es un ejemplo similar a La fontana de oro, El audaz y los Episodios de Don Benito. Se escribe en 1880, pero en ella Don Pedro Antonio realiza toda una reconstrucción de los "tipos" y "cuadros" de una ciudad andaluza por los años de 1840. La obra de Alarcón es "costumbrista" (porque la novela histórica es un género perteneciente al "costumbrismo"), es también una "novela arqueológica" que tiene por marco una época bastante cercana al momento en que escribe su autor y por este mismo hecho puede adjudicársele también con plena tranquilidad el marbete de "novela de costumbres contemporáneas" ${ }^{\prime 2}$ ). En resumen, la historia de Manuel y Soledad reconstruye (en 1880) el universo ideológico y circunstancial de la época romántica (concretamente el del año de 1840) en un ámbito determinado, una ciudad de Sierra Morena.

\section{"Desfaciendo entuertos"}

El presente artículo comenzaba con el planteamiento de un interrogante: ¿es El Niño de la Bola una novela perteneciente al Romanticismo o al Realismo? Sólo podemos responder a esta interrogación clarificando qué es una novela romántica y qué es una novela realista.

Ambas, según lo que llevamos dicho, participan de una misma base ideológico-formal, el "costumbrismo". Por otra parte, éste ha sido definido en nuestras páginas como una técnica "realista" de análisis de caracteres y costumbres ("tipos" y "cuadros") que va en búsqueda de una definición de los "modos de sentir, de soñar, de amar y de creer" de una colectividad, pueblo o "raza". Los hombres de la segunda mitad del siglo XIX, como vimos, intentaron convertir la "novela de costumbres" en privativa de su época llamándola

La novela moderna, la que retrata la sociedad actual y encarna los ideales y sentimientos que a nuestro siglo animan; la que al interés dramático de los sucesos une el interés fisiológico producido por la acabada pintura de los caracteres y el interés social engendrado por los problemas que en ella se plantean; la que sustituye con ventaja a la antigua epopeya y

12. Así lo hizo Juan Valera en su artículo "La poesía lírica y épica en la España del siglo XIX":

Bien puede decirse que Alarcón comparte con Fernán Caballero la gloria de haber resucitado en nuestro país la novela de costumbres contemporáneas... Las dos joyas que me inspiran el anterior elogio son El sombrero de tres picos y El Niño de la Bola (Valera, 1942, pág. 1217). 
representa con pasmosa verdad y brillantes colores la vida compleja y la conciencia agitada de la sociedad presente, no tenía cultivadores en España (Revilla, 1883, pág. 109).

Estos hombres eran conscientes de que la pintura de "tipos" o caracteres y de "cuadros" o costumbres componía básicamente la novela que ellos escribían, pero erraron en creer que estos dos elementos eran una novedad de su época. Ramón de Mesonero Romanos interpretaba, años antes que los anteriores, con una mayor precisión histórica el origen y desarrollo, así como el futuro, de las bases constitutivas de toda novela. En la historia de este género reconocía que "en tres diversas clases puede dividirse la composición que, desde los principios de la literatura, tuvo por objeto reproducir en un cuadro de invención los diversos matices del humano carácter y las vicisitudes de la vida social" (Mesonero Romanos, 1839, pág. 253). A saber, en "la novela fantástica o maravillosa [de caballerías] la novela de costumbres [picaresca y Cervantes] y la histórica o tradicional [Walter Scott]" (ibid. Subrayados del autor) ".3. Mesonero Romanos reconoció que "tipos" y "cuadros" los ha habido siempre en la novela, lo que iba cambiando con el tiempo era el grado de realismo/idealismo de la reproducción (a saber, el mayor o menor nivel de bastardía reconstruyendo la realidad) y era el momento histórico elegido como marco de la obra (la época contemporánea al autor o cualquier período pretérito). Con gran puntería crítica, Don Ramón define ya, ¡en 1839!, lo que debe ser una buena "novela de costumbres" "ha de describir costumbres, ha de desenvolver pasiones, ha de pintar caracteres" [ibíd., pág. 2545]), y cómo esas "costumbres", "pasiones" y "caracteres" pueden convertirse en una buena "novela arqueológica" si se enlazan "naturalmente con los nombres históricos" y "vengan a formar el cuadro general de una época marcada en la historia de cada país" (ibid.). Reflexionando sobre estas citas, queda claro que lo "nuevo" en la novela del XIX fue la consciencia en la reproducción "costumbrista" de la realidad, es decir, en el hecho de que el análisis minucioso-científico de "tipos" y "cuadros" tenía un solo fin, "formar el cuadro general de una época", ya fuera ésta pretérita o presente.

El "Costumbrismo" (reproducción "realista" + "formar el cuadro general de una época") es lo que une la novela de la primera (Romanticismo) y la segunda mitad del siglo XIX (Realismo/Naturalismo). Pero, ¿qué las separa? Yo diría que únicamente un hecho. La "novela de costumbres (contemporáneas)" tiene por marco histórico la historia de la actualidad mientras la "novela arqueológica" se interesa por el pasado nacional.

13. Igual clasificación aceptaba por los mismos años Juan Guillén Buzarán diciendo: "Yo divido las novelas en tres clases: novelas históricas, novelas ficticias y novelas de costumbres" (Guillén Buzarán [1841] 1984, pág. 230. Subrayado del autor). 
El Niño de la Bola justifica literariamente los lazos que unen todo el siglo XIX español con la época ilustrada, representando también un caso limítrofe entre la "novela arqueológica" y la "novela de costumbres" y destruyendo de esta manera el falso muro levantado entre el Romanticismo y el Realismo. El género al que pertenece la obra del novelista andaluz es el primero de los mencionados (novela histórica), sin embargo, haciendo un análisis del período del Romanticismo, tan próximo a la actualidad, coincide con la "novela de costumbres (contemporáneas)" en hallar los ancestros que lo originaron (el Siglo de las Luces) y en vislumbrar las consecuencias que él mismo provocó (a saber, la peculiar psicología del hombre de la segunda mitad del XIX). En suma, El Niño de la Bola es una explicación literaria del puente que existe entre el XVIII y el XIX españoles ${ }^{14} \mathrm{y}$ de la continuidad teleológica entre la primera y la segunda mitad de este último. La novela ayuda pues a "desfacer" uno de los grandes "entuertos" interpretativos de nuestra historia literaria.

\section{BIBLIOGRAFÍA}

ALARCÓN, Pedro A. 1880. El Niño de la Bola, Madrid, Víctor Saiz.

-. 1884. El Niño de la Bola, Madrid, Pérez Dubrull.

ALAS, Leopoldo. 1889. Benito Pérez Galdós. Estudio crítico-biográfico, Madrid, Ricardo Fe.

-. 1981. La Regenta, ed. G. SOBEJANO, 2 vols., Madrid, Castalia.

ALCALÁ GALIANO, José. 1871. "Noticias literarias. La fontana de oro", Revista de España, XX, págs. 148-158.

ALTAMIRA Y CREVEA, Rafael. 1921. "Un drama de Galdós", Arte y Realidad, Barcelona, Cervantes.

BESER, Sergio, ed. 1972. Leopoldo Alas: Teoría y crítica de la novela española, Barcelona, Laia.

GUILLÉN BUZARÁN, Juan. [1841] 1984. "Discurso sobre la influencia de las novelas", La novela aragonesa en el siglo XIX, ed. de R. M" Andrés ALONSO, Zaragoza, Guara, págs. 224-232.

GINER DE LOS RÍOS, Francisco. [1864] 1969. “De la poesía épica y en particular de la epopeya", Ensayos, ed. J. LOPEZ-MORILLAS, Madrid, Alianza, págs. 53-63.

IRIARTE, Tomás de. 1986. El señorito mimado. La señorita malcriada, ed. R. P. SEBOLD, Madrid, Castalia.

ISLA, José Fco. de. 1960-1964. Fray Gerundio de Campazas, ed. R. P. SEBOLD, 4 vols. Madrid, Espasa-Calpe.

MESONERO ROMANOS, Ramón de. 1839. "La novela", Semanario Pintoresco Español I, págs. 253-255.

$14 \mathrm{Al}$ igual, por ejemplo, que El audaz de Don Benito Pérez Galdós. 
MONTESINOS, José F. 1960. Costumbrismo y novela, Berkeley-Los Angeles University of California Press.

NAVARRETE, Ramón de. 1847. "La novela española", Semanario Pintoresco Español XII, págs. 82-84, 117-119 y 130-131.

PALACIO VALDÉS, Armando. 1878a. "Los novelistas españoles. D. Francisco Navarro Villoslada", Revista Europea, núm. 22, págs. 712-714.

-. 1878b. "Los novelistas españoles. D. Benito Pérez Galdós", Revista Europea, núm. 212, págs. 335-339 y núm. 214, págs. 400-405.

—. 1878c. "Los novelistas españoles. D. Manuel Fernández y González", Revista Europea, núm. 222, págs. 659-663.

PARDO BAZÁN, Emilia. 1973, Cuentos. Crítica literaria (selección), tomo III de las Obras completas, Madrid, Aguilar.

PÉREZ GALDÓS, Benito. 1870, “Observaciones sobre la novela contemporánea en España. Proverbios ejemplares y proverbios cómicos, por Ventura Ruiz Aguilera”, Revista de España XV, núm. 57, págs. 162-172.

—. [1897] 1972. "La sociedad presente como materia novelable" y "José María de Pereda, escritor" Ensayos de crítica literaria, ed. L. BONET, Barcelona, Península, págs. 173-182 y 189-204.

REVILLA, Manuel de la. 1883. "D. Pedro Antonio de Alarcón” y "D. Benito Pérez Galdós", Obras de..., Madrid, Víctor Saiz, págs. 91-100 y 109-116.

SEBOLD, Russell P. 1977. "Historia clínica de Clara: La mogigata de Moratín", Estudios ofrecidos a Emilio Alarcos Llorach, 2 vol., Oviedo, Servicio de Publicaciones de la Universidad de Oviedo, vol II.

-. 1988. "El duque de Rivas, novelista", $A B C, 16-4-1988$, pág. 72.

TYTLER, Graeme. 1982. Physiognomy in the European Novel. Faces and Fortunes, Princeton, Princeton UP.

VALERA, Juan. 1942. Crítica literaria. Estudios críticos. Historia y política. Miscelánea, vol II de Obras completas, Madrid, Aguilar.

VIDART, Luis. 1882. "El naturalismo en el arte literario y la novela de costumbres. Un viaje de novios, por Emilia Pardo Bazán. Madrid, 1881", Revista de España LXXXV, núm. 338, págs. 181-197. 



\section{INGREDIENTES MODERNISTAS DE UN POST-ROMÁNTICO: V. W. QUEROL}

Jordi GRACIA

Universidad de Barcelona

La deliberada paradoja del título es una invitación a rebajar el filo de cortes historiográficos demasiado terminantes. Que el modernismo no fue invento personal de Darío no es ninguna novedad y tampoco habría de serlo que algunas de sus raíces y adivinaciones existen en autores que, como Bécquer o Rosalía, fueron explícita y continuamente admirados por sus máximos poetas. Donald L. Shaw observó con sagacidad el posible impacto de Querol, Vicente Aguilera o Balart en cierto modernismo, desde el Ismaelillo de Martí o el Viaje sentimental de Villaespesa al propio Antonio Machado [Shaw, 1981, pág. 106]. Existen en algunos de ellos ingredientes estéticos adoptados por el modernismo poético y algunas de sus vetas temáticas más definidoras. Tanto desde el simbolismo, "forma de expresión lírica existente en todo tiempo", define R. Gullón [Gullón, 1963, pág. 22], como desde el tono intimista, callado y melancólico, es fácil registrar líneas de fuerza o estímulos poéticos que, aprendidos o no en la tradición más reciente, persisten y se desarrollan en la estética literaria del modernismo.

V. W. Querol obtuvo una notable estimación contemporánea a pesar de los segundos y terceros lugares que la historia ha ido reservándole. Una clara evolución estética y personal llevó sus versos desde los iniciales fervores quintanescos hasta una sensibilidad afín al Bécquer aprovechado por los modernistas. En el camino practicaría una poesía de tonos suaves, lánguidos, asomada melancólicamente a la aspereza del tiempo, dócil al encanto y la calidez del hogar familiar y seducida por un cierto simbolismo espontáneo. Un afán de sugestión de atmósferas sentimentales cuadra insospechadamente con poemas del Machado primero o, en una esfera de logros considerables, con el Unamuno más apegado al calor hogareño. Ese "vivir en olor de melancolía" 
que reivindica Gullón para Casal, Silva, Gutiérrez Nájera o Darío, y, claro, Juan Ramón o Machado [Gullón, 1963, pág. 14], permite enhebrar los datos que postulan una continuidad estética entre un romanticismo español desencajado y la plenitud de un modernismo menos huérfano de lo que se pretende. Continuidad que, en este caso, no vendrá sostenida en el positivismo estricto de un préstamo o una influencia, aunque el ejercicio podría ser viable: los recuerdos que dedican Unamuno o Azorín a este poeta valenciano ayudan a aislar ingredientes de uso modernista porque, entre otras cosas, también aquí se trata de una afinidad sentimental canalizada, ocasionalmente, por un registro poético identificable. En intención, en técnica, en capacidad selectiva y, en definitiva, en lenguaje poético, Querol puede ofrecer, debidamente escogidos, elementos válidos de comparación con el simbolismo más paradigmático aunque también menos atrevido. Todavía demasiado ligada al cañamazo de un diseño clásico, alguna rima al estilo de Bécquer apunta a un simbolismo no programático. "A orillas del ancho rio" es un excelente ejemplo de esa aproximación, y como tal,

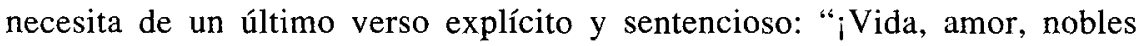
intentos!" (1964, pág. 31).

El ideario poético de Querol se recoge en distintas composiciones de carácter circunstancial. Las más interesantes son las epístolas a Gaspar Núñez de Arce, por sus Gritos de combate (como subrayaría Valera, 1878, pág. 263) y la que destina a $\mathrm{P}$. Antonio de Alarcón, con quien mantuvo una relación bastante estrecha en algunos momentos de su vida '.En esta última carta, "acerca de la poesía", pueden espigarse reflejos muy congruentes con su época pero también con aquel "último baluarte, el único reducto invulnerable de ser" que Gullón hizo patrimonio de los modernistas: la "invención salvadora" que anima la Poesía en mayúsculas, el Ideal rubeniano de arranque romántico [Gullón, 1963, pág. 39]:

¡Numen severo de la historia!
todo lo que el poëta
con sabio ritmo sonoro escribe;
muere lo que desdeña!-

La confianza en la palabra escrita- "mi fe en ti", escribe Querol en el mismo poema (pág. 4) - evoca ciertamente la enérgica defensa, tan característica del modernismo, de la poesía vinculada a elementos visionarios y mágicos. Incluso anticipa algo de ese peculiar misticismo del vate que trasciende la inmediatez de los sentidos y canta la esperanza ante el misterio, tan romántico y

1. El libro de Luis Guarner, 1976, es, pese a un incómodo deje hagiográfico, el trabajo documental y biográfico más completo sobre el autor, aunque muy pobre en el análisis de su obra. Contiene, sin embargo, una muy útil cronología de las obras de Querol, págs. 335-339. 
tan inaccesible como la "adusta perfección", como el "secreto ideal" que Rubén Darío exaltaría en "Yo soy aquel que ayer..." o "El coloquio de los centauros":

el vate, el sacerdote, suele oír el acento desconocido; a veces enuncia el vago viento un misterio...

[Darío, 1987, págs. 56-57 y 96]

El mismo recurso aparece en la poética de Querol, con una intención análoga y que hace suficientemente explicable la coincidencia de dos estéticas vinculadas por el mismo desdén hastiado por el presente y el mismo afán de trascenderlo en la creación poética:

fiel sacerdote que custodia oculto

$$
\text { ... Es el poeta }
$$

del viejo dogma el profanado culto, o es del lejano porvenir profeta.

(pág. 24)

Dualidad semejante a la de estos versos de la "Carta a Don Gaspar Núñez de Arce" está presente de nuevo en otros lugares. La Carta a Alarcón cede a la Poesía, hija de la belleza y del sentimiento,

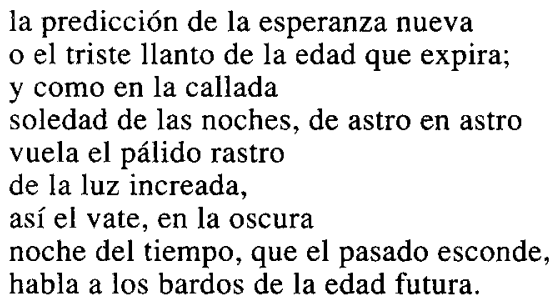

(pág. 6)

La reflexión de Querol sobre la poesía y su función es claramente deudora de una base romántica que, de manera residual pero revitalizada con distintos elementos, llega al modernismo. La sacralización de la poesía en manos de los jóvenes autores modernistas recobra las dosis de fe y entusiasmo que la poesía campoamoriana diluye en un escepticismo a menudo explícito o, si se quiere, en un tácito acuerdo con el entorno, encubierto por actitudes cínicas y descreídas. En este sentido, las consignas de Querol a Núñez de Arce por sus Gritos de combate entran en perfecta armonía con el diseño de esta estética:

haz que en las almas libres

la fe, el amor o el entusiasmo brote;

marca su ruta al caminante incierto.

(pág. 25) 
Este mesianismo explícito en su concepto de la poesía, como dirección espiritual de la humanidad, —con "toda la gravedad y trascendencia de la del rector de pueblos", apostilla J. M. de Cossío [Cossío, 1960, II, pág. 891] - no está muy lejos del ideario modernista, en lo que tiene además de remedo clásico [Shaw, 1981, pág. 103].

La carta a Pedro A. de Alarcón (¿1876?) presenta todavía otras muestras del lenguaje poético de Querol que no es difícil vincular al "neorromanticismo a cuyo impulso se desvanecieron los desvaídos ecos de los retoricistas suplantadores" [Gullón, 1963, pág. 32]. La poesía, dice Querol,

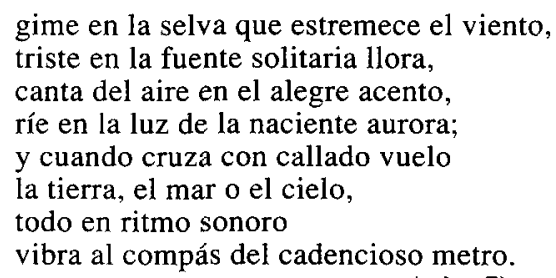

(pág. 7)

Cierto que, por ejemplo, el primero y cuarto de los versos transcritos no sintonizan con la sensibilidad a que apuntan los otros, pero éstos son testimonios de interés de una renovación interior de la poesía, como algunos más, que doy seleccionados de la misma carta:

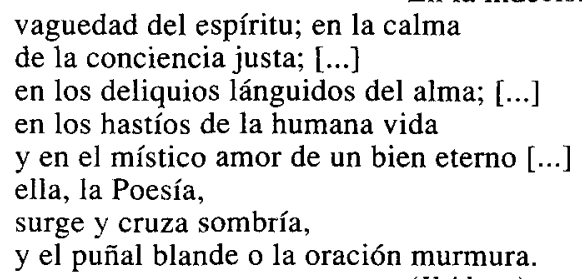

(Ibídem.)

El último verso parece refrendar en su construcción bimembre y disyuntiva la selección que he practicado al transcribir el pasaje. Los versos omitidos verifican la imagen más tópicamente romántica del puñal blandido (pasión y énfasis) mientras los transcritos caminan mejor por la senda de la murmuración sin estridencias ni efusiones, un rezo sentimental y silencioso que se ha de hacer tantas veces paradigmático de un cierto modernismo hispanoamericano y español.

Fuera ya de los planteamientos teóricos, la revisión de su obra poética permite obtener también algunos resultados estimables. Por entre versos ligados de pies y manos al romanticismo formulario, se filtra inesperadamente una 
sensibilidad extemporánea. Crece la afinidad con modulaciones líricas menos afectas a la retórica enfática y más dadas a la sugestión de atmósferas, a las vivencias sencillas concebidas en el tiempo y experimentadas como transcurso sosegado, a la complacencia en estados de ánimo ambiguos e indefinibles y, sobre todo, a la nostalgia y la melancolía. El aprovechamiento simbólico y sugerente de ciertos elementos del paisaje y la tonalidad baja y ensordecida de algunos versos de Querol hacen de este poeta ejemplo imprevisto de un registro universal particularmente explotado por la sensibilidad modernista.

Aplazando para un momento posterior la poesía familiar de Querol, la mejor acogida por la crítica moderna y coetánea del autor, de Valera, Unamuno o Azorín a Cossío o Guarner, propongo ahora algunos fragmentos que justifican el entramado de paradojas estéticas que quiere registrar este trabajo. La presencia de un yo poético confidencial y secreto resulta un excelente pie forzado para la detección del callado fluir de la temporalidad, vertida en formas alusivas a la vaguedad de un estado de ánimo. Una vitalidad contradictoriamente agonizante, todavía asida a la esperanza porque "mal apagado el fuego de los años/aún, removiendo la ceniza, humea," "Epístola a un amigo", pág. 10), canta desde imágenes de un considerable rendimiento lírico:

Por la arboleda umbrosa y escondida muevo la planta perezosa, incierta de dulces sueños con el alma henchida.

(Ibidem)

Sombras y silencio que se asocian al crepúsculo como dato referencial de un neorromanticismo que puede encontrar hitos válidos tanto en las formas más características de un Antonio Machado- "Las ascuas de un crepúsculo morado..."- como en la del Gimferrer más visionario de "El arpa en la cueva":

Cuando tras las colinas del ocaso el sol su disco enrojecido esconde, marco en la playa el vacilante paso; marcho abstraído sin saber a dónde, y a la honda voz de mis secretos triste el gemido de la mar responde.

(pág. 11)

La dicción estrictamente poética, desde la sintaxis hasta una incapacidad casi total para la elipsis, aleja sin duda este fragmento de Querol de las referencias aducidas más arriba, pero el aprovechamiento de imágenes y de una adjetivación bastante identificable los hace respirar con una visible complicidad. La imaginería sencilla e intencionada, cuando supera una gratuidad demasiado frecuente en el Querol de composiciones más ambiciosas y fallidas, presenta a las claras su dependencia intelectual y estética de un concepto de la poesía que superarán Bécquer o Rosalía y, en su senda, los modernistas. En la 
"Carta al señor don Alfredo Weil, poeta", composición muy posterior a su etapa de plenitud (1859-1876), subraya Querol el distinto registro con que accede la poesía, ahora, en 1886:
No ya la hermosa,
la enardecida poesía aquella
de mis antiguas juveniles odas, sino la triste musa del recuerdo que las muertas imágenes evoca.

(pág. 27)

No logra, sin embargo, explotar este potencial lírico, esta nueva disposición, en la estrofa siguiente, demasiado ligado de nuevo a estructuras poéticas y sintácticas tan rígidas que impiden la inflexión sentimental que pide el itinerario de la memoria. Un deficiente sentido de la economía poética estraga determinadas imágenes al apropiárselas una estructura sintáctica, y un estrofismo, al fin y al cabo, no permeable a vaguedades sentimentales y afectivas como las que intenta expresar e imita, según escribe en la misma carta:
¡Ah!, si lograse yo que enternecidas
fueran voz de mis cánticos, la forma no imitaría nebulosa y triste, de los vates germánicos.

(pág. 28)

En seguida manifestará un abierto rechazo por la tonalidad más sensiblera, de origen germánico, pero es una hostilidad que debe matizarse a la vista de algún dato recogido en la obra de Andreu Gonzálbez, 1935. Se reproduce aquí la carta dedicatoria del homenaje que rinde a Llorente el Ateneo valenciano el 23 de enero de 1886, firmada en primer lugar por Querol, quien con toda probabilidad debió escribirla, y el resto de ateneístas, después. A propósito de la traducción que Llorente preparó de Heine (Barcelona, 1885), interesa recoger los términos en que se refiere a la poesía de los famosos suspiros, tan aborrecida de Núñez de Arce. Querol aprecia positivamente la dificultad de

\begin{abstract}
encerrar en nuevo cuerpo y nueva forma ese espíritu vago, sutil, intangible y vaporoso del poeta germánico, como es locura querer aprisionar en el aire el invisible aroma de las flores [...] poesía indecisa, cambiante, indefinida, de Heine, cuyas sensaciones se parecen más a las que produce el ritmo y las melodías musicales que a las que engendran las ideas habladas [Gonzálvez, págs. 98-99 y Sánchez Moguel, 1893].
\end{abstract}

Los versos de Querol evocan a menudo el concepto de lo que la crítica británica llamó "pathetic fallacy", que destempla el aire de monótona sencillez con que fluye el verso. Tengo a la vista una rima de inspiración netamente becqueriana $-\mathrm{y}$ de las que llevan a un cierto Juan Ramón y un frecuente $\mathrm{A}$. 
Machado- que se ve rota, sin embargo, cuando la retórica más impersonal sustituye a la evocación de un recuerdo o un sentimiento. Se trata del comienzo de la rima XI, y del final, que recupera conscientemente el mismo elemento simbólico que abre el poema y cuya continuación es muy inferior:
¿Ves esa lámpara triste
que en la olvidada capilla
del viejo templo cristiano,
junto a la virgen bendita,
las sombras apenas vence, pero inalterable brilla?

Todavía lejos de los mejores logros del simbolismo, Querol acude a los términos referenciales que tranquilizan una conciencia estética incapaz de rebasar los límites de su propio registro poético:

Yo sé de un alma que arde por ti en casto amor, oh niña, como la lámpara triste de la olvidada capilla.

(pág. 38)

La evocación de cualquier mediocre grabado de época es simultánea al sonido inconfundible de una adjetivación que es literal y es simbólica, al uso machadiano que a tantos malentendidos dio lugar. Lámpara triste, olvidada capilla, viejo templo, luz que apenas vence las sombras, son algunos de los ejemplos que justifican un anticipo germinal de los usos poéticos del modernismo, más allá del evidente becquerianismo de la rima.

La composición más rica en imágenes y más imaginativa es un largo poema que Querol titula sintomáticamente "Visión" y cuya singularidad estriba en la explotación intencionada de recursos que, como los elementos fantásticos, apenas usaría en otros poemas. Joan Alcover, en una apreciable revisión de la obra del valenciano, publicada en dos entregas de La Vanguardia (1921) destacó en el poema al Querol que "supo renunciar a la frondosidad densa y copiosa para alcanzar con la concisión lapidaria el vivaz halago de la fantasía" [Alcover, 1951, pág. 660]. Es este rasgo que puntualiza Alcover el que más convincentemente justifica una vecindad estética insólita entre un cierto Querol y la riqueza imaginística del Ismaelillo de Martí.

En cualquier caso, y muy de acuerdo con los usos modernistas, el recuerdo va a ser el mejor aliado expresivo que encontrará la poesía de Querol. Si la "Carta a mis hermanas", que Luis Guarner fecha en 1876 [Querol, 1964, pág. 90], jalona sus estrofas con un significativo "¡Todo subsiste como entonces!" para entregarse a su recuento, la citada "Carta al señor don Alfredo Weil, 
poeta", diez años después, no deja lugar a dudas sobre el papel que progresivamente ha de desempeñar la memoria:

¡Musa de los recuerdos!

todo a mis ojos cambia, y todo cobra

¡Aún con ella

vida y color y movimiento!

(pág. 27)

Este recurso, sin embargo, atrae hacia sí una tonalidad normalmente teñida de nostalgia y amarga placidez. En Querol es un instrumento de reconstrucción de escenas familiares perdidas o irrepetibles por la ausencia de alguno de sus miembros. La eficacia de la memoria y la sutileza sentimental de sus evocaciones entusiasmaron a Unamuno del mismo modo que han sido el precario asidero al que la crítica ha podido acudir para revisar la obra de Querol ${ }^{2}$.

El resultado más satisfactorio obtenido desde la evocación del pasado como eje vertebrador del poema está en relación con la poesía de ámbito familiar y doméstico. A pesar de los numerosos lugares en que Unamuno consignó su predilección por esta faceta de Querol, no llegó a identificar el recuerdo y la memoria como el ingrediente clave de su simpatía por el "entrañado poeta" [Unamuno, 1958, I, pág. 735]. Y no es casual que sean "horas de languidez y desgana de estudio" las que le impulsan a releer los versos de Querol y singularmente los cuartetos dedicados a la infancia feliz de "A un árbol". La persistencia de la renovación primaveral que vive el árbol está ausente del ánimo del poeta, "rugosa la frente y seca el alma" que ante el árbol "evoca las memorias indecisas / de la edad juvenil" (pág. 84).

Este "dulcísimo y jugoso Querol" [Unamuno, 1958, I, pág. 735] es, por otra parte, el mismo que Valera apreciaba: "mejor poeta subjetivo que objetivo; esto es, que vale más cuando expresa sus propios sentimientos; cuando hace, por decirlo así, examen de conciencia..." [Valera, 1878, pág. 267]. En la misma línea de Unamuno, para Valera "lo mejor de Querol son sus poesías amatorias y sus poesías inspiradas por el afecto a su familia" [ibíd., pág.279]. Insisto una vez más en señalar el terreno de la memoria familiar como el que mejor resultado lírico dio a Querol - con el respaldo de lector tan singular como Unamuno: “doy todo Zorrilla por las cosas que Querol decía de sus padres y su hermana muerta, o las que a sus hermanas vivas decía" en torno al pasado común de la familia [García Blanco, 1951, pág. 65]. Esta "Carta a mis hermanas" a que alude Unamuno y que Cossío destaca como una "de las más representativas del sentimiento familiar" [Cossío, 1960, II, pág. 894] que

2. Existen abundantes referencias: los artículos "La frontera lingüística" y "Frente a los negrillos", en Unamuno, 1958, I, págs. 809 y 735-739; "Vascuence, gallego, catalán", VI, págs. 788-794. De otros, como "El zorrillismo estético", da referencia García Blanco, 1951. 
modula la poesía de Querol, contiene elementos que evocan poderosamente la tonalidad entre alicaída y nostálgica de la poesía de fin de siglo y modernista. Toda la carta se compone sobre el recuerdo del hogar

donde corrieron, para nunca volver, los dulces años de nuestra infancia, donde eterno vive vuestro recuerdo, hermanas.

(pág. 90)

El recurso estructural de la enumeración traza el itinerario por los espacios conocidos y cuya adjetivación vuelve a ser decisiva: las puertas cerradas que el poeta abre "con gemidos / plañideros" y que

entre el vago

silencio, suenan como a voces tristes

de las muertas memorias del pasado.

(pág. 91)

Y el familiar eco de las campanas, en tantos modernistas, suscita de nuevo la sensación de un romanticismo en cuya agonía se pierde el rumbo de la enfática afirmación, sustituida por la complaciente memoria de un pasado idealizado:

\section{Suena \\ el esquilón del viejo campanario de la antigua iglesia, y suenan lentos \\ del transeúnte los medidos pasos por la desierta calle.}

(pág. 93)

También en "Ausente", dedicada a su hermana tempranamente desaparecida, Querol regresa al paisaje más personal y conseguido de su poesía. El ámbito de la infancia ahora se resuelve en una imaginería de la decadencia y el abandono, aunados a la melancólica "lección del paisaje de nuestra tierra", en palabras de Unamuno [Unamuno, 1958, I, pág. 739]. Desde el "viejo portal” de "fondo oscuro" o el "tosco muro / del caserón" hasta la "casa natal deshabitada y vieja" junto a "las alamedas del río / donde vagué soñando a mi albedrío" (pág. 100), es fácilmente perceptible la inflexión de una voz nueva e imperfecta, descontenta con la sonoridad ampulosa de antaño e imantada por un registro murmurador, aquietado y melancólico.

Poco más es lo que da de sí el camino propuesto. Querol se sujetó en la mayoría de sus composiciones a esquemas que no tendrían continuación en el modernismo, o al menos, no en modulaciones afines a las suyas, pero sí supo encontrar la voz personal en un filón que tanto explotaría Unamuno, sobre 
todo, pero que ya puede evocar en registro distinto el Ismaelillo de Martí. Esta manera delicada y sentimental que he tratado de subrayar tiende delgados cabos hacia obras de algunos poetas del modernismo, y hacia una sensibilidad distinta amparada bajo su rótulo. Bien pudo decir Azorín de Querol que "es la sensibilidad que se halla en el límite preciso en que, unos centímetros más, y entrará en el terreno de la sensiblería" [Azorín, 1941, pág. 189].

No se trata tanto de rescatar a un poeta olvidado como de señalar anticipos no desdeñables para una sensibilidad poética que combate el agotamiento de un discurso recargado e íntimamente insatisfactorio. Querol es un buen ejemplo de estados de transición estética por su mismo abandono de la poesía en virtud de una dedicación profesional absorbente. La promesa de unos aires nuevos está en sus versos tímidamente y se limita al simbolismo intimista de modos suaves y callados, seducido por la memoria sentimental y receloso ante la ruidosa celebración de pasiones arrebatadoras. Por supuesto que es en Bécquer donde arrancan los pasos más firmes para "una evolución de las formas poéticas que desembocaría en la depuración de su romanticismo que es, en realidad, el primer modernismo" [Crespo, 1980, pág. 29]. Pero quizá algunas briznas de esta modalidad más alusiva y sugeridora que presentativa debía estar intuyendo Azorín en los versos familiares de Querol cuando anotó como clave de su poesía "el conflicto entre lo que se ve y lo que se quiere ver y es imposible ver. Por tal sensación aguda y lacerante que el poeta nos da, suscita nuestra predilección" [Azorín, 1941, pág. 190].

Desde 1876 , con su traslado a Madrid como jefe nacional de tráfico de la Compañía Ferroviaria MZA, su labor poética fue escasa y a menudo sólo circunstancial. Una rápida aproximación al epistolario cruzado con su amigo Teodoro Llorente documenta ese casi total abandono de la poesía pero, sobre todo, su deseo de volver a ejercer como poeta "no con los vuelos de la imaginación, escribe en 1889 , el año de su muerte, pero sí con las reflexiones de una benévola filosofía, que es musa de los viejos" [Llorente, 1928, pág. 224]. Los asomos de un cierto modernismo, los anticipos que indicaban una incomodidad básica y cordial con su propia tradición, parecen quedar arrumbados definitivamente. El propio Llorente le había animado a escribir y Querol responde, en junio de 1884 , con una agenda intolerablemente apretada y un desolado: “cómo hacer versos en tales circunstancias?" [Llorente, 1928, pág. 129; véase pág. 89,138 , etc. $\}$. Las referencias aumentan a lo largo del epistolario. Esta continua postergación de la poesía, a la vez que su misma llamada urgente e íntima, desgarrada a veces entre el deber profesional y el deseo, el cansancio y el ansia, permite conjeturar alguna hipótesis explicativa. Querol parece encarnar en su propia persona y trayectoria poética, con el abandono de una fuente de compensaciones vitales como era la poesía, la dinámica histórica y espiritual que condujo al modernismo. Pero su sentido es inverso: todo queda 
en mero anticipo, o, si se quiere, en mero atisbo de un camino de la sensibilidad al que no va a dar continuidad, del que irá alejándolo implacablemente la sumisión de las formas de vida de un alto ejecutivo ferroviario sin tiempo para los versos (pero sí para acusar su ausencia).

Leído el modernismo en la versión que de él ha dado Octavio Paz como "nuestro verdadero romanticismo" y como "respuesta al positivismo, la crítica de la sensibilidad y el corazón, también de los nervios, al empirismo y cientificismo positivista" [Paz, 1981, pág. 105], Querol se sitúa de espaldas con un gesto de resignación e impotencia mal dominados. Algo de respuesta a esa misma atmósfera que combatiría el modernismo (y que es la biografía del jefe nacional de tráfico de MZA) hay en las lastimosas quejas de Querol a su amigo Llorente, pero lo hay también, anticipadamente, en la parcela de su poesía, sencilla y directa, todavía rígida y seca, que hemos examinado. La profundización complaciente y cálida en el sentimiento familiar, por un lado, y la depuración de la espesa retórica que los versos de Bécquer habían de sentenciar, permiten perfilar la imagen de un poeta sin dotes especiales que, sin embargo, intuyó en su propia poesía la urgencia de una renovación. Vista su poesía sobre el fondo de una biografía literaria abortada o truncada, cobran un valor nuevo los esbozos de modernismo que hemos ido señalando. Significan la respuesta fallida e interrumpida de su autor en dos frentes: el de unos usos poéticos que fueron en otra época los suyos propios (sus odas patrióticas quintanescas) y ante los que dejó de conmoverse, por un lado, pero también, el otro, el desdén y el hastío por unas formas de vida que únicamente por la vía vergonzante y privada de la correspondencia se vio capaz de impugnar a fondo.

\section{BIBLIOGRAFÍA}

ALCOVER, Joan. 1951. Obra Completa, Barcelona, Selecta, Biblioteca Perenne 14. AZORÍN. 1941. Valencia, Madrid, Biblioteca Nueva.

COSSío, José María de. 1960. Cincuenta años de poesía española (1850-1900), Madrid, Espasa-Calpe, 2 vols.

CRESPO, Angel. 1980. Antología de la poesía modernista, Tarragona, Ed. Tarraco.

DARÍO, Rubén. 1987. Poesía, Barcelona, Planeta, prólogo de P. GIMFERRER.

GARCÍA BLANCO, Manuel. 1951. "El poeta valenciano V. W. Querol y Unamuno", en Revista Valenciana de Filología, 1, págs. 63-71.

GONZÁLVEZ, Andreu. 1935. El árbol y sus frutos. Teodoro Llorente y Oliveras, su esencia y su espíritu, Valencia, Tip. Moderna.

GUARNER, Luis. 1967. Poesías desconocidas de Vicente W. Querol, Madrid, C.S.I.C.

-. 1976. Poesía y verdad de Vicente W. Querol, Valencia, Institución Alfonso el Magnánimo. 
GULLÓN, Ricardo. 1963. Direcciones del modernismo, Madrid, Gredos.

LLORENTE, Teodoro. 1928. Epistolari I (1861-1900). Cartes de llevantins, Barcelona, Biblioteca Balmes.

PAZ, Octavio. 1981. "Traducción y metáfora" en Lily LITAVK, ed., El modernismo, Madrid, Taurus, págs. 97-117.

QUEROL, Vicente Wenceslao. 1964. Poesías, Madrid, Espasa-Calpe, Clásicos Castellanos 160, ed. de Luis GUARNER.

- 1985. Obras Completas, I, Valencia, Consell ${ }^{\mathbf{a}}$ Cultura, ed. Luis Guarner.

SHAW, Donald L. 1981. Historia de la literatura española. 5. El siglo XIX, Barcelona, Ariel, $7^{\mathrm{a}}$.

UNAMUNO, Miguel de. Obras Completas, Barcelona, Afrodisio Aguado-Vergara.

VALERA, Juan. 1878. "Rimas de D. Vicente W. Querol", en Obras Completas, Madrid, t. X, págs. 263 y ss. 


\title{
CLARÍN, GALDÓS Y PARDO BAZÁN FRENTE AL TEATRO DE JOSÉ ECHEGARAY
}

\author{
Librada HERNÁNDEZ \\ Furman University
}

El deseo de dirigir racionalmente el progreso hacia una nueva sociedad lleva a los novelistas de la Restauración a un examen detallado de los problemas nacionales. El impacto reformista nacido con la Revolución de 1868 se evidencia en el florecimiento de la novela. En ella se intenta profundizar el análisis de la situación del individuo dentro de su circunstancia y su relación con todos los elementos de la sociedad. La novela será un método de análisis a través del cual se puede exponer lo intrínseco de la sociedad representado en su mínima unidad, el individuo. Si la novela es el instrumento que lleva al examen completo del individuo, el teatro representa la síntesis de la realidad de ese individuo en un plano colectivo. La mayoría de los novelistas que forman parte del grupo restauracionista considera importante el teatro para el progreso de la sociedad y pone énfasis en su regeneración. Casi todos los escritores piensan en Émile Zola y apoyan su propuesta de acercar el teatro a la novela. Los intentos de incorporar los dos géneros dan como resultado en España un fenómeno de intercambio; se lleva el teatro a la novela y ésta se escenifica en las tablas.

Además de adoptar técnicas teatrales y de explorar en la novela realidades dramáticas, los novelistas se acercan al teatro de la época con una lupa revisionista. Los tres novelistas más distinguidos de la época, Leopoldo Alas "Clarín", Emilia Pardo Bazán y Benito Pérez Galdós están de acuerdo en la imperiosa necesidad de cambiar las formas teatrales. No obstante, cada uno se acerca al género partiendo de su propia experiencia con la novela y por lo mismo asumen que el realismo es el medio apropiado para la escena. Al examinar los problemas dramáticos, los tres enfocan en la obra de José Echegaray puesto que es su teatro el de más éxito público durante la Restauración. Debido a su extensa popularidad y a su retórica basada en la espectacularidad, el teatro 
de este dramaturgo se ha considerado como uno que apoya la ideología establecida. Sin embargo, su teatro causa polémicas; mientras el público lo aplaude, los críticos moderados se ofuscan ante la "inmoralidad" y el "romanticismo revolucionario" y lo acusan de propagar la mentalidad liberal del 68. Tal es el caso de los tres críticos que de él se ocupan en La Ilustración Española y Americana, Peregrín García Cadena, Manuel Cañete y Eduardo Bustillo. Inclusive críticos más cultivados como Manuel Revilla lo rechazan debido a que no se ajusta a las preceptivas artísticas del "buen tono" y la "naturalidad" introducidas por Leandro Fernández de Moratín y su escuela.

Los tres novelistas antes mencionados se concentran en el teatro de Echegaray y a diferencia de los críticos moderados que lo atacaban de "inmoral" y a pesar del público que lo aplaudía como espectáculo romántico y fantasioso, se proponen buscar en él elementos que expliquen la dinámica interna de la sociedad de su época. En su afán por encontrar una orientación positiva en el teatro de su tiempo frente al anterior aceptan que en el aparatoso y espectacular teatro de Echegaray hay cabida para la nueva ideología revisionista.

A diferencia de la crítica periodística de tendencia moderantista que ve en el popular dramaturgo al corruptor del público, Clarín insiste en que su contribución a la escena española representa un paso positivo en la regeneración del teatro. Los estudiosos que se han ocupado de la obra de Clarín señalan esta atracción hacia el teatro de Echegaray como una expresión de favoritismo hacia un colega de su misma afiliación política. Roberto Sánchez apunta que no se trata sólo de un capricho por defender a un liberal, sino que la "afición" de Clarín por el neorromanticismo acusa una añoranza por un pasado que también se da en otros escritores de su tiempo:

En muchos casos este secreto regusto del romanticismo teatral escondía a fines del siglo un quedar insatisfechos con esa visión realista-naturalista de las cosas que, a fin de cuentas, ya llevaba un nuevo idealismo o simbolismo. (1963, pág. 227).

La constante admiración del crítico por la obra de Echegaray nos hace pensar que su teatro, aun cuando se separe de los moldes de escuelas, inclusive del positivismo, presenta una concordancia ideológica con sus coetáneos.

Con respecto al teatro como género, Clarín observa que históricamente ha reflejado y ha influido en la formación del hombre de un tiempo determinado. Siguiendo el dictum hegeliano de que el teatro florece en épocas en que la conciencia individual está muy desarrollada, trata de encontrar en el de la suya rasgos positivos que reflejen la soceidad. El crítico comparte la idea general de su época de que en relación con la novela, el teatro estaba atrasado y necesitaba ponerse al día. Este género, aún más que la novela, por estar en directa 
comunicación con la masa, representa un importante instrumento de renovación. Clarín apunta como rasgo distintivo del género las circunstancias especiales en que se da el fenómeno teatral: la relación y coincidencia de autor, actor, empresario y público. Indica que tiene que haber una concordancia en estos elementos porque en el arte escénico "la expresión es compuesta". No obstante, mejor que la novela, este arte puede "secundar el movimiento de la cultura porque representa la síntesis y esencia de la misma". Aunque la novela suele exponer la situación dramática del hombre, la esencia de lo dramático tiene su desarrollo ideal en el teatro. De ahí que este género ocupe un lugar primordial en su crítica literaria y que sea objeto de análisis aun dentro de su misma novela.

Clarín creía que en la sociedad moderna el hombre debía ser el punto de partida en que toda renovación se basase y afirmaba que en el teatro es el carácter, no la acción, lo más importante. Su postulado para un nuevo teatro llama la atención sobre el personaje y su relación con el medio en que se desarrolla (Sánchez, 1987, pág. 464). Para representar al hombre moderno dentro de su problemática, el dramaturgo debía servirse del método realista que en las novelas estudiaba al personaje desde varios puntos de vista. Al mismo tiempo, el crítico propone que la renovación dramática tenga como meta la eliminación del idealismo en las tablas. Sin embargo, resalta el hecho de que dadas las circunstancias especiales en que se efectúa la obra teatral, dicha reforma sólo se podía llevar a cabo por alguien que conociera el teatro y sus límites en cuanto a los medios de expresión. Para llevar el conflicto real del individuo al teatro, el dramaturgo tenía que estar al día y ser, sobre todo, poeta. Así lo expresa en su artículo "El teatro de lejos" (1893) donde afirma que el intento de llevar la novela al teatro hecho por Galdós no resulta ya que el género "necesita quien le reforme, por ejemplo, un poeta que comprenda esa necesidad y no sea novelista". Es decir, el renovador además de ser consciente de la problemática contemporánea, debe manejar el arte escénico. En su época el teatro no va por este camino. Incluso los franceses no consiguen seguir las pautas sentadas por Zola y se limitan a la imitación burda de la realidad. Las circunstancias propias para el nuevo arte dramático se habían dado sólo en los países nórdicos, donde Ibsen imperaba como verdadero hombre de teatro (1892a).

En la última mitad del siglo, en España. no existía, según Clarín, nadie que pudiera llevar a cabo la renovación. Ayala y Tamayo eran los dramaturgos más perfectos, pero no los mejores porque su teatro pretendía "oscurecer el progreso de los modernos" debido al excesivo fin moral con que querían obtener la admiración del público. De hecho el siglo XIX no había producido un teatro que representara su época. En todo el siglo no se destaca "una obra colectiva, un renacimiento nacional de la literatura dramática, en que poetas, críticos, público y ambiente social concurran a dar al espíritu español el tinte especial 
que le señala con esa particular tendencia del genio patrio en el siglo XVII..." (1889, pág. 78)

Echegaray es un caso aislado cuyas ideas modernas unidas al romanticismo y al teatro clásico procuran expresar la identidad nacional. Para Clarín, su talento no se amengua ante los franceses y si había faltas y exageraciones en él, su magnitud no era más significativa que la del teatro de la época. En 1881 en el ensayo "El libre examen y nuestra literatura presente" lo coloca junto a Galdós como "la representación legítima y digna de nuestra revolución literaria" ya que su teatro, al igual que la novela de Galdós, rompía moldes obsoletos y se plegaba a la ideología progresista: "Echegaray personificaba el libre vuelo de la fantasía y el libre examen en la escena..." (pág. 75) Clarín ve en Echegaray al reformador que a través de su producción traspasa las barreras establecidas por sus contemporáneos. El dramaturgo rompre con el teatro de su época e incorpora la mitología del drama de capa y espada, la brillantez y plasticidad del romanticismo y la problemática del hombre moderno para llevar al público un teatro que encarna ese período de la historia.

En los estudios que Clarín dedica a Echegaray resalta la afinidad de su dramaturgia con el teatro clásico español y el interés por los problemas contemporáneos. En su primer artículo "Mar sin orillas" (1881) acusa a la crítica de superficial:

Echegaray, hoy como el primer día de su gloriosa aparición en la escena española, es un fenómeno del teatro; merece estudio, lo exige detenido y exento de preocupaciones; la crítica se ha contentado con consagrarle conceptillos o antítesis cursis, gastadas y altisonantes, según el gusto de cada crítico. (pág. 123)

Clarín manifiesta entonces que el teatro de Echegaray era la mejor respuesta a la ideología moderada representada por la comedia burguesa. Su teatro tenía el valor de enfrentarse con "un público dividido entre revolucionarios, más o menos prudentes o sabios, burgueses pacíficos, cuya idea del arte les hacía alabar, ante todo, la buena intención" (pág. 123). El dramaturgo es pues el rebelde que ensancha moldes y rinde justas y merecidas batallas con un público de "buena intención" que trata de angostar el avance teatral.

En ese primer artículo Clarín examina el drama Mar sin orillas (1881) como un ejemplo en que se aplica el libre examen a la escena. En su análisis intenta probar que la obra se encamina hacia una nueva concepción del teatro que enfoca en el personaje más que en la fábula. El autor se ajusta entonces a lo que el crítico estimaba más importante en el drama:

Como el drama es la poesía plena de la humanidad, lo que interesa ante todo es la resultante de las propiedades humanas, como fuerza, en la 
convivencia social, influidas por el medio en que obran, y a la vez influyentes...(pág. 134)

La importancia de este drama reside en las escenas de gran intensidad dramática que exponen el conflicto pasional como esencial al individuo y que se manifiesta a través del personaje. Por lo mismo, el dramaturgo se acerca al teatro moderno que lleva como propósito el estudio del individuo en la sociedad. No obstante el drama no es del todo perfecto debido a que enfoca demasiado en la acción. Clarín afirma que aunque la obra no se ajuste a las normas realistas que todo teatro moderno tenía que tener en cuenta, sí acarrea el espíritu moderno en tanto que muestra conciencia del conflicto entre individuo y sociedad. Era precisamente por el desajuste del aparatoso teatro echegarayano con las reglas del teatro bien hecho de Tamayo y Ayala que los críticos moderados lo habían atacado. Clarín, contestando a los revisteros de la época, dice que "hay que atreverse a renovar, y dejemos que se atreva ese que llaman todos los gacetilleros de la villa genio desorientado" y añade que "a la larga siempre acierta el que se fía del genio" (pág. 137). Por ende considera que los errores de acción, no ofuscaban las situaciones culminantes:

Hay Mar sin orillas como eclipses de la acción que desorientan a muchos espectadores; pero el atento, no sin lamentar este notable defecto de composición, admira la belleza de la fábula, que es de gran fuerza dramática; enérgica por el interés del conflicto, el vigor y entereza de los caracteres, y aun por la sencillez de su contenido. (pág. 124)

En 1886 Clarín examina el drama De mala raza y responde a las observaciones de los críticos teatrales que achacan la popularidad del dramaturgo al hecho de pertenecer al grupo liberal. Según rezaba los ataques de los periodistas, el éxito de la obra había sido causado por "hombres de partido" y no por un público interesado en sus aparatosas "inmoralidades". Clarín refuta entonces esta acusación:

No hay justicia en decir que a Echegaray se le perdona todo, y a Tamayo o cualquier otro poeta que no fuese liberal no se le perdonara nada... Se necesita el valor de un Echegaray para entregar a un teatro, tal como andan ahora, una obra que exija algo más que un solo actor bueno. (1886, págs. 62-63)

El autor se le presenta como un verdadero rebelde al llevar a la escena un drama con tintes naturalistas, muy lejos de la comedia de salón de Ayala y Bretón y manteniendo vivo a la vez el espíritu del liberalismo de 1868. Encuentra que es digno de aplaudir tal intento, especialmente en una época en que escasean los buenos actores. Al igual que en Mar sin orillas, hay en esta obra fallos de composición interna. En ambos casos Echegaray tiende a abultar la acción y a alargarla demasiado. En total le parece una composición defectuo- 
sa y contraria a las leyes de la perspectiva teatral y ello:

hace que en parte se malogre concepción tan hermosa y tan magistralmente expresada en aquellas últimas escenas del acto segundo, que son de lo mejor que ha escrito Echegaray, y sobre todo, acaso lo más natural, lo más cercano a la verdad bella, lo más interesante por la fuerza y la exactitud con que se hace hablar a las pasiones, (ibíd., pág. 66)

A partir de esta idea de que el teatro de Echegaray anda por buen rumbo puesto que lo único que le falta es deshacerse de la acción, Clarín analizará la obra en detalle señalando errores en escenas accesorias que no realzan al personaje central. Es en la aparición del protagonista en la escena, cuando cobra sentido la acción y el drama adquiere dimensiones de obra clásica:

Hasta que entra Vico [representando el personaje principal] el interés no se presenta. Pero entonces sí; la pasión fuerte y noble, decidida a triunfar porque se siente legítima, habla allí con el vigor hermoso y fresco, casi candoroso con que sabe Echegaray representar estos caracteres... que en suma, demuestran ser en poesía descendientes directos de aquellos héroes de los romances y de la comedia de Lope y Calderón, a pesar de las alteraciones y cambios naturales del tiempo. (ibíd., págs. 36-37)

Entusiasmo tal es, sin duda, halagador no sólo a la concepción del personaje por parte del dramaturgo, sino que deja ver el valor escénico de un actor como Vico. En la obra el conflicto se establece una vez más entre el individuo y el mundo en que se mueve siendo aquél víctima de las reglas irracionales de la sociedad. Clarín concluye que Echegaray logra en la exposición de tal conflicto incorporar lo glorioso del teatro clásico al teatro de la época. Debido a esta convergencia del pasado en el presente la obra se acerca entonces al teatro moderno: "después de situaciones y diálogos como aquellos [...] creo a Echegaray capaz hasta de dar con esa mosca blanca que se llama el teatro conpemporáneo, casi casi naturalista" (ibíd. pág. 72). Aunque el crítico se adelanta a señalar ciertos errores de técnica, le interesa más advertir los aspectos positivos y en especial pone énfasis en la importancia que se da a la pasión como aspecto esencial del ser humano.

Más tarde, en 1890, Clarín insistirá que las obras de Echegaray son las únicas que se ajustan a una concepción moderna del teatro. Con motivo de la muerte de Rafael Calvo, Clarín escribe uno de sus Folletos literarios titulado Rafael Calvo y el teatro español (1890) en el que asocia al gran actor con la producción dramática contemporánea. Las obras de Echegaray, dice, sufrían a causa de que no había buenos actores en España. La época en que su obra destaca es aquella en la que coincide con dos eminentes intérpretes, Antonio Vico y Rafael Calvo. Vico, con su versatilidad y estilo realista, había enfatizado algunos aspectos positivos del dramaturgo. No obstante fue Calvo, con su 
acentuada declamación romántica y su medida interpretación quien lo había llevado a la fama. Como ocurre con frecuencia en la historia del teatro, el autor despierta el talento del actor y éste proporciona realce a la creación imaginativa. La combinación Echegaray-Calvo había resultado acertada:

nos ha hecho vislumbrar lo que pudo haber sido, lo que podrá ser cualquier día que Dios quiera un teatro español idealista, en que nuestro genio nacional despertara o despierte con sus cualidades nativas, sin olvidar las enseñanzas y las exigencias del tiempo, pero enlazándose a la tradición gloriosa con la sarta de perlas que el romanticismo de los García Gutiérrez y Rivas nos dejó para gloria suya y esperanza nuestra. (1889, pág. 58)

En la unión de Echegaray, Calvo y Vico, Clarín ve la esencia de la tradición escénica española. Juntos proporcionan al espectador "verdaderos placeres espirituales, de pura estética y de un género nacional, tan nacional como puede ser el capeo..." (ibíd. pág. 60). Esta facilidad con la que el dramaturgo se ajusta a sus actores, es considerada por Clarín como esencial en la renovación de todo teatro y sugiere que si en España existiesen diferentes y mejores compañías teatrales, Echegaray sería capaz de abandonar su primer romanticismo. Esta capacidad de adaptación se hace evidente en la variedad de su obra, la cual se había ajustado siempre a las circunstancias teatrales:

Para mí hay tres Echegaray, mejor dicho, hay cuatro. Uno es el Echegaray de los dramas románticos, poéticos, legendario, casi siempre en verso, llenos de visiones y de escalofríos o temblores; el Echegaray que suele gustar al público inteligente, al de las inverosimilitudes, al que tan bien pinta Bourget, hablando de los espectadores de los estrenos de París; el Echegaray que tampoco solía gustar a Revilla: el de Mar sin orillas, digno de Shakespeare, a pedazos; el de En el seno de la muerte; éste es el Echegaray de Calvo. (ibíd., págs. 59-60)

Dos años más tarde en 1892, Clarín volverá a aplaudir un nuevo intento de renovación escénica en las producciones del autor. Entonces califica la obra de Galdós Realidad y la de Echegaray El hijo de don Juan como "ensayos de renovación" (1973, pág. 75). Se muestra satisfecho de que Echegaray incorporase a Ibsen a las tablas españolas, aunque aclara que aquél no imita sino que coincide con el gran dramaturgo nórdico. El hecho de que el drama de Echegaray no esté a la altura del de Ibsen se debe a que el público no está preparado para una reforma similar a la de los países del norte. A la vez el crítico utiliza el argumento muy de la época de que el teatro de la época no cuaja en España porque parte de un temperamento distinto al peninsular. Dada la tardía recepción del teatro de Ibsen en Europa (según Gregerson no es hasta 1891 cuando único se puede hablar de una amplia influencia del noruego en el continente, págs. 90-95) se justifica claramente la preferencia por Echegaray como representante del modernismo teatral europeo en España: 
Ibsen no fue apreciado en lo que vale ni aun con las hábiles atenuaciones y la cuidadosa aclimatación de Echegaray; Ibsen hubiera sorprendido más, tal vez impresionado más en una fiel traducción, pero el éxito total hubiera sido peor; se le hubiera gustado menos y apenas se le hubiera entendido. (1892a)

No se puede negar que Clarín coincide con el neorromanticismo pues muestra cierta añoranza por la grandeza dramática del período inmediato, que irrumpe en los moldes de contenidos y formas clásicas, pero que no ignora el pasado glorioso de la tradición. Esa tradición reafirma la esencia de lo nacional y por lo mismo el intento de hacer un teatro nuevo tiene que incorporar esta tradición. Dentro del teatro de su época Echegaray era el único que tendía a unificar lo nuevo y lo tradicional; aunque no llega a ser en el teatro moderno español una figura de la envergadura de Ibsen, sí tuvo éxito al romper con el moderantismo de la comedia burguesa. Por esto mismo en la crítica clariniana Echegaray es considerado innovador, no imitador; representa el impulso liberal de romper con el pasado y aliarse al futuro.

Galdós observa inteligentemente el progreso de Echegaray en relación con el espíritu de la época. En 1885, considera que el teatro está en total abandono porque no se habían superado todavía las normas gramáticas impuestas por el público de los años anteriores:

El público burgués y casero dominante en la generación última, no ha tenido poca parte en la decadencia del teatro. A él se debe el predominio de esa moral escénica, que informa las obras contemporáneas, una moral exclusivamente destinada a aderezar la literatura dramática, moral enteramente artificiosa y circunstancial, como de una sociedad que vive de ficciones y convencionalismos. (1885b, pág. 155)

Galdós afirma que en el público teatral los cambios de gustos generalmente ocurren muy despacio y está convencido de que la regeneración del teatro se dificulta porque el género se dirige a una masa ideológicamente aforme. La renovación dramática no puede ocurrir del todo hasta que el público cambie:

[el público] impone su gusto a autores y cómicos, y si alguna modificación beneficiosa soñáis para el porvenir, no lo intentéis sin procuraros un público nuevo, accesible a las novedades, cosa en verdad más difícil de lo que a primera vista parece. (ibíd.)

Galdós más que nadie se da cuenta que el progreso en el teatro está directamente ligado a límites impuestos por el público. Puesto que el teatro se dirige a una multitud y no a un individuo en particular, el papel que juega el dramaturgo es esencial y aun más difícil de desempeñar que el del novelista. Aquél se encontraba entre la espada y la pared al tener que complacer a un público que bostezaba ante lo viejo y al mismo tiempo desdeñaba las formas 
nuevas que no comprendía. Galdós parece resignarse ante este hecho cuando acepta que la renovación teatral está subyugada por el público:

La emoción fatal, la que ha de producirse en el nivel medio de la inteligencia, no resulta las más de las veces sino con situaciones ya vistas y admiradas otra vez. Individualmente, se acepta lo nuevo. Pero la masa, la colectividad tarda bastante en aceptarlo. Es que la emoción colectiva es y será siempre un misterio. Las multitudes no vibran sino con ideas y sentimientos de fácil adquisición, con todo aquello que se saben de memoria, y se tiene ya por cosa juzgada y consagrada. (ibíd., pág. 159)

La renovación del teatro tal y como la ve Galdós está en la reconciliación entre la nueva necesidad de cambio y las costumbres arraigadas en la masa. Con ser tan difícil, Galdós piensa que puede llevarse a cabo si alguien sabe manejar la técnica dramática. Esto sólo podía hacerlo Echegaray cuyo primer teatro había tenido el mérito de impresionar al público con técnicas y temas románticos y cuyo sabio uso de la retórica teatral le había permitido llegar hasta unos espectadores cansados de la literatura dramática neoclásica:

Pocos autores han tenido sobre las tablas éxitos tan estruendosos, tan ardientes, como don José de Echegaray; verdad que pocos han tenido en tal grado el arte de conmover y producir impresiones hondísimas. (1885a, pág. 138)

El intento del dramaturgo, sin embargo, no se pudo continuar porque sus imitadores carecían de habilidad "mecánico-dramática". Por lo tanto en este campo Echegaray era el único capaz de cambiar el arte escénico:

Para que el teatro entre con pie derecho en la escuela de la naturalidad es preciso que un autor de grandes alientos rompa la marcha y acometa con recursos de primer orden esta gran reforma. Echegaray, que posee la capacidad más vasta que es posible imaginar, es el llamado a marcar este camino. (ibíd., pág. 145)

Galdós admira en Echegaray la fuerza de construcción dramática. Más que nada, advierte en algunas obras una naciente tendencia a un realismo escénico, que mostraba dotes para llevar al teatro por un nuevo rumbo. No obstante, Galdós pensaba que el aparatoso dramaturgo tenía que cambiar las convenciones escécnicas y ajustarse al nuevo estilo realista:

En algunas obras de este poeta hay escenas que demuestran su aptitud para el género realista, y cuenta que lo califico así dando a la palabra la mayor amplitud posible. La experiencia se encargará de convencer al insigne dramaturgo de una verdad incontestable, y es que el drama histórico ha pasado a los libretos de ópera... (ibíd., pág. 144)

En la actitud que el novelista toma ante la producción de Echegaray muestra 
una visión clara de la diferencia entre realismo novelístico y teatral. Para él, el realismo escénico está sujeto a las convenciones teatrales. Este concepto del realismo escénico lo aleja de la visión clariniana que proponía un total acercamiento a las técnicas de la novela en el teatro. Galdós parece conocer mejor al público y darse cuenta de cómo operan los cambios ideológicos en la masa. Quizás esto explique el que haya tenido más éxito en el teatro que Clarín, quien trataba de deshacer los viejos moldes. Galdós tiene conciencia de los límites formales del teatro. No quería revolucionar la forma; distinguía entre el "convencionalismo esencial y tradicional" y el "convencionalismo amanerado". Quería que se regresara al teatro de todos los tiempos y es ampliamente sabido que al llevar sus novelas al teatro las cambió para que se ajustaran a las convenciones teatrales. De hecho en algunas de sus novelas se nota una tendencia a exaltar los aspectos dramáticos de la realidad, sobre todo, en lo que al diálogo se refiere. Por lo tanto, no encuentra divorcio entre el realismo y los artificios teatrales:

no excluye este género [el realismo] la intensidad de los efectos, por el cual creemos que el gran dramaturgo se hallará en él, como en esfera propia, desde el momento en que se propusiera cultivarlo. Las grandes facultades de Echegaray lucirán más aplicadas a un género en el cual los fulgores de la invención dan realce más vivo a las líneas severas y propias de la verdad. (ibíd., pág. 145)

No pide Galdós que se cambien las estructuras introducidas por Echegaray, sino que se usen para presentar la verdad. El novelista se dio perfecta cuenta del problema que representaba el realismo en la escena; observa que "no hay arte en que la ficción de la naturaleza esté más cohibida que en el teatro [...] Y no se comprende que en esto pueda traernos grandes innovaciones la dramática del porvenir”. (1889b, pág. 155)

En esta temprana época Galdós considera a Echegaray apto para llevar a cabo un cambio teatral porque piensa en los aspectos estructurales del drama como importantes y capaces de presentar la nueva ideología realista. Cuando seis años más tarde Galdós tome la renovación del teatro por cuenta propia, todavía pensará lo mismo y echará mano de las convenciones esenciales del teatro para hacer su obra. De hecho en sus memorias habla de cómo se sentía halagado cuando Echegaray visitaba los ensayos de Realidad y La loca de la casa. Es de suponer que las novelas adaptadas para el teatro ya tenían cierta afinidad formal con la estructura dramática que admiraba en Echegaray.

Emilia Pardo Bazán considera que en la literatura el progreso se logra a través del método experimental similar al expuesto por Zola con respecto al teatro. Estudia a Echegaray en varias reseñas de Nuevo Teatro Crítico en que examina el teatro de la época. Al igual que Clarín, defiende al dramaturgo ante 
la crítica, sin dejar de anotar como error fundamental la "extensión"; las obras son demasiado largas para su gusto. Dentro del teatro de la época hace notar que el de Echegaray es el único con valor estético. Según su observación, su teatro es "la columna que sostiene el palacio ruinoso de nuestro drama nacional, convertido por Eguilaz en casa de tres pisos..." (1892, pág. 943). Echegaray supera a su época porque es el único caso de "supervivencia de los viejos dramaturgos". Su teatro es "profundamente castizo" y los errores que generalmente se le imputan en la prensa son los mismos que se encuentran en Lope y Calderón. Su obra representa la tradición nacional en la literatura dramática, la “reacción literaria, la tradición, no académica, sino popular" (ibíd., pág. 944). El público y la crítica entonces tienen el deber de aplaudirlo y estudiarlo.

Al examinar la obra echegarayana, Pardo Bazán llega a la conclusión de que su producción pasó por dos estadios sujetos a los cambios históricos de la sociedad. La coincidencia entre la obra y las necesidades de la sociedad en un momento dado son indicios del interés del dramaturgo por los problemas de su tiempo. Aunque el público no asistía a las obras de teatro, la escritora no consideraba que la decadencia en el teatro fuera solamente endémica a España:

No tenemos aquí media docena de autores dramáticos de mérito sobresaliente; tampoco los tiene Francia, ni ninguna nación europea. No producimos aquí al año media docena de dramas o comedias notables; tampoco Francia las produce... (ibíd., pág. 1083)

Frente a este estancamiento en el teatro europeo, Echegaray representa la única figura que moviliza al teatro español. De ahí su afán de clasificar su obra con el fin de demostrar su vigencia. Señala en este respecto dos estadios, o "maneras", marcados por la tendencia a ponerse al día con los gustos y los géneros literarios. Según la novelista, una vez que Echegaray se da cuenta de que su primera producción, la que va de 1874 a 1890 , se aparta de las necesidades de la época trata de ensanchar su campo ensayando nuevos estilos: "No admitió Echegaray ni la posibilidad de rezagarse. Bien sabía él que su escuela, la de los dos decenios del setenta al noventa, atrás se había quedado..." (ibíd., pág. 1083). Esta toma de conciencia se inicia en su dramaturgia a partir de la comedia satírica Un crítico incipiente (1891). Pardo Bazán cree que esta obra representa el abandono de la primera faz "super-romántica". No es que esa época haya sido negativa para el progreso del teatro, ya que ella misma admira obras como El gran galeoto y En el seno de la muerte, sino que no tiene ya sentido propagar el romanticismo en esos años. En la sátira a la pedantería de la crítica hecha por Echegaray en la mencionada obra (tema, dicho sea de paso, constantemente tratado por la misma escritora) ve un serio intento de regeneración: "se me figura en extremo favorable para nuestro estado sanitario intelectual" (1891b, pág. 965). De hecho apunta que el traer ese tipo de comedia a las 
tablas sigue la tradición "experimental" de la literatura moderna y le anima a que continúe:

Siga, pues (no es consejo, ... es súplica de aficionado, de admirador, de diletante); [sic] siga haciendo comedias literarias, que tan cual es la primera, nos ha dado un rato delicioso, nos ha refrigerado y nos ha demostrado una vez más que en Echegaray existe veta, veta, veta... [sic] veta de plata nativa y maelable. (ibíd., pág. 968).

Pero el valor de la obra reside fundamentalmente en su apartamiento de las producciones primeras. El mismo público había demostrado su complacencia por el cambio al otorgarle un fuerte aplauso. Echegaray, al darse cuenta de que su primer teatro no atrae al público, comienza su obra experimental. Va a Francia y descubre allí el drama de tesis introducido ya por Dumas fils, Los Goncourt, Sardou, Augier y otros, pero no se deja llevar totalmente por su entusiasmo y robustece su inspiración en otras figuras, Moratín, Shakespeare, Ibsen, Tolstoi. Es esta búsqueda de nuevos rumbos, lo que Pardo Bazán admira más en su obra. En sus escritos sobre el dramaturgo pondrá énfasis en el espíritu renovador y examinará con más cuidado las obras en que advierte inclinaciones de parecida tentativa.

Si el primer paso experimental explora la vena cómica con mucho acierto, el segundo va más allá, pues lo acerca a Ibsen. En El hijo de don Juan (1892) Pardo Bazán observa el interés de Echegaray por la literatura universal y su afán de volcar esa expresión cultural en el teatro de su patria. El mérito está precisamente en "el intento de buscar nuevos rumbos y tantear todos los géneros y aventurarse por todos los caminos..." (1892, pág. 1083). Aun cuando lo nuevo no se ajuste totalmente a la realidad nacional, la escritora cree que la crítica ignora los aspectos más importantes de la obra:

Salió mal el ensayo, y con notoria sin razón, en vez de limitarse a decir lisa y llanamente que esto mismo, que el ensayo había salido mal, se atacó reciamente a Echegaray por la manía de buscar rumbos nuevos y se le aconsejó que volviese a hacer El gran galeoto... (ibíd., pág. 1085)

Al igual que Clarín, la novelista aplaudirá los intentos renovadores aun cuando no sean aceptados por el público. En este respecto coincide también con Galdós cuando insiste que la decadencia teatral está en el público: "no se hable de soñadas decadencias, si no es que se refieren a la decadencia del paladar nacional". (ibíd., pág. 1084) Sic vos non vobis (1890) avanza un paso más. Esta obra representa la confirmación del progreso experimental que dejaba definitivamente atrás el primer teatro romántico y aún el ibsenismo, poco funcional en España:

Sic vos non vobis, más aún que El hijo de don Juan era un síntoma del estado de conciencia de su autor, que sintiendo la opresión moral de 
tantos horrores, tantos conflictos, tantos pavorosos desenlaces, solicitaba ya algo idílico, plácido, sencillo... (ibíd., pág. 1085)

La evolución de estas obras culmina con Mariana (1892), que es la cúspide del intento de regeneración; en ella Echegaray pone todo su conocimiento: "Debe de haber puesto Echegaray en Mariana sus cinco sentidos y tres potencias, y además toda la experiencia del veterano en las ideas dramáticas..." (ibíd., pág. 1086). El entusiasmo por la obra del dramaturgo lleva a Pardo Bazán en varias oportunidades a la arena de la polémica cuando refuta a críticos como Fernández Villegas (Zeda), quien en La España Moderna le había sugerido que no abandonase el teatro neorromántico con el cual tanta fama había obtenido y le pedía que se apartase de Ibsen. La autora hace una lista de los errores del crítico y concluye que Mariana es la mejor obra porque representa el único teatro posible dentro de la España de la época. El teatro que se produjo con Mariana es aceptable en tanto que franquea la vía hace una versión hispánica del simbolismo centrada en las realidades del país:

Era evidente que los tiempos pedían algo que no fuese ni las burdas peladas fórmulas del naturalismo de escuela a la francesa, ni podía tampoco ser, en España por lo menos, la apocalíptica visión de los países del hielo y de la eterna sombra. (ibíd., pág. 1085)

$\mathrm{Al}$ igual que Clarín, Pardo Bazán no está totalmente convencida de que la dramaturgia de Ibsen sea la apropiada para España; afirma que la adaptación de este nuevo teatro había encontrado el autor más capacitado en Echegaray. El dramaturgo representaba un paso positivo porque al experimentar con las nuevas formas no abandona lo "castizo y nacional" de la dramaturgia española donde la realidad ha existido siempre.

Es esta actitud de tolerancia hacia un colega que todavía conecta el movimiento romántico con el realista y termina coincidiendo con el simbolismo que hace de la postura de los restauracionistas una de añoranza. Clarín, Galdós y Pardo Bazán forman el bloque intelectual más importante de la Restauración. De cierto modo los tres encarnan el deseo de revitalización que trae consigo la Revolución del 68. En su intento de mejoramiento aplican a su examen las corrientes idealistas de la época. Clarín piensa que la verdadera sociedad liberal se lograría a través de la armonía entre lo tradicional y lo moderno; Pardo Bazán cree en una sociedad que tome en cuenta un espiritualismo como el de Tolstoi; Galdós piensa en incorporar lo esencial y natural del ser humano a la sociedad. El programa revisionista de estos escritores se encuentra delineado en la novela. Consideran este género como el que más se presta al examen y regeneración de la sociedad y al teatro, por ser género que depende del público, lo consideran retrasado ya que la masa no está al tanto de las innovaciones. Para estos novelistas, Echegaray es el mejor dramaturgo de la época. En él ven 
al rebelde liberal que se enfrenta con el teatro del antiguo régimen e impone la tradición romántica; representa al experimentador que, conociendo los límites intelectuales de su público, traspasa las fronteras de tiempo e intenta traer nuevos moldes a la escena.

\section{BIBLIOGRAFÍA}

ALAS, Leopoldo. 1881a. "Del teatro", en Solos de Clarín, Madrid, Fernando Fe, págs. 46-62.

-. 1881b. "El libro examen y nuestra literatura presente", en Solos, págs. 62-76.

-. 1881c. "Mar sin orillas", en Solos, págs. 120-39.

-. 1886. Un viaje a Madrid, en Folletos Literarios, I, Madrid, Fernando Fe.

-. 1889. Rafael Calvo y el teatro español, en Folletos Literarios, VI, Madrid, Fernando $\mathrm{Fe}$.

-. 1892a. "Ibsen y Echegaray", La Correspondencia de España, 23 y 28 de Abril.

-. 1892b [1973]. "Realidad y El hijo de don Juan como ensayos de renovación dramática", en Palique, Barcelona, Labor, 1973, págs. 75-85.

- 1893. "El teatro de lejos", Los Lunes del Imparcial, 20 de Marzo.

BESER, Sergio. 1968. Leopoldo Alas, crítico literario, Madrid, Gredos.

GREGERSON, Halfdan. [1936] 1976. Ibsen and Spain: A Study of Comparative Drama, Cambridge, Harvard University Press, 1936; Kraus Reprint Co., 1976.

MARTÍNEZ CACHERO, José Ma . 1983. "La actitud antimodernista del crítico Clarín", Anales de Literatura Española, 2, págs. 383-98.

PARDO BAZÁN, Emilia. [1891a] 1973. "El estreno de Echegaray", Nuevo Teatro Crítico, 1; en Obras completas, II, Madrid, Aguilar, págs. 943-44.

-. [1891b] 1973. "La comedia de Echegaray: Un crítico incipiente", La Ilustración Artística, 481; en Obras, III, págs. 965-68.

-. [1892] 1973. "El estreno de Mariana, de Echegaray, o cuando Lope quiere..., quiere", Nuevo Teatro Crítico, 24; en Obras, III, págs. 1083-92.

PÉREZ GALDÓS, Benito. [1885a] 1923. "Echegaray", Nuestro Teatro, en Obras inéditas, V, ed., Alberto Ghiraldo, Madrid, Renacimiento, págs. 137-50.

-. [1885b] 1923. "Viejos y nuevos moldes"; en Obras inéditas, págs. 151-65.

SÁNCHEZ, Roberto G. 1963. "Clarín y el romanticismo teatral: Examen de una afición", Hispanic Review, 31, págs. 222-30.

—. 1987. "Clarín y su Teresa y los cómicos", Hispanic Review 55, págs. 463-74. 


\title{
THE OTHER MAJOR SOURCE OF HUERTA'S RAQUEL: ESTHER
}

\author{
Gregory B. KAPLAN \\ University of Pennsylvania
}

To Russell P. Sebold for his generosity and guidance

In proposing a new source for Vicente García de la Huerta's dramatic masterpiece, Raquel, I am in no way rejecting the obvious one that has long since been established. As critics have shown, Huerta was one of a number of authors who expanded on the famous episode of the love between Alfonso VIII and a Jewess of Toledo that is narrated in the Crónica General of Alfonso el Sabio '. However, in writing his eighteenth-century version, Huerta did not simply retell the legend of the Judía de Toledo. René Andioc has demonstrated how Huerta adapted the story to fit the contemporary political situation and has underlined the themes that give Raquel a strongly political bent ${ }^{2}$. Unfortunately, critical emphasis on the political situation at the time of the creation of Raquel, and the obvious connections the play has with the legend of the Judia de Toledo, have seemed to negate Huerta's other options. But Huerta was in no way limited to the aforementioned models and influences. I will demonstrate the existence of a new source that, next to the Judia de Toledo, represents the most significant influence present in Raquel.

The present study will focus upon the relationship between Raquel and Esther, one of the five Megillot (scrolls) of the Apocrypha. Esther is the story

1. For a list of the other authors who have dealt with the theme and the correspondences between Raquel and these other works see Ríos Carratalá (1987, págs. 78-90), Segura Covarsí (1951) and Johnson (1972). For the nineteenth-century versions see Ríos Carratalá (1986-87).

2. See Johnson (op.cit.), and see Andioc's introduction to Raquel. All citations in this study will come from this edition and will be listed by act and verse number. 
of an attempt to massacre the Jewish people. This attempt is stopped only when Esther, a Jewess who has come to be queen of Persia, adheres to the advice of Mordecai, her uncle and counselor, and intercedes by confronting King Ahasuerus. She eventually succeeds in thwarting the efforts of the man responsible for the threat, the villainous courtier Haman ${ }^{3}$. Though the pervading theme is the unsuccessful attempt at eradicating the Jews, Esther is appealing for a variety of reasons such as its religious significance, the debate over its historicity and its merit as literature. According to Robert Gordis, "The Purim story has all the ingredients of an engrossing play" (1974, pág. 15). It is not therefore difficult to imagine that Huerta may have considered Esther a highly attractive source for his tragedy.

The various similarities that exist between the plots of Esther and Raquel make for an interesting starting point when comparing the two works. In both stories the Jewish heroine receives important advice from her counselor, advice that will be crucial in determining the outcome of the story. In chapter four of Esther the Jewess, after having been named queen by Ahasuerus, is informed by Mordecai of Haman's plot to kill the Jews. Though she is well aware that she risks death by making an unauthorized appearance before the king she is advised by Mordecai to do so in order to intercede on behalf of her people. Esther heeds this advice and visits the king. It is then when she is able to begin to plan the eventual salvation of the Jews and the destruction of her enemy Haman. Only because she permits the advice to influence her is Esther able to foil her enemy's scheme. In other words, it is Mordecai's advice which serves as one of the focal points in determining how the plot changes course.

We note a parallel in the role Rubén's advice plays in Raquel. Russell P. Sebold has underlined the importance of the heroine's acceptance of the advice by identifying it as her "yerro disculpable" (1989, pág. 311). It is precisely because Raquel follows her counselor's advice, to get back royal favor for herself and for her people, that the plot takes a different direction leading to her murder. Although the threat against the Jews is much less emphasized in Raquel, Huerta's heroine, like Esther, sees herself thrust into a position by her advisor where she must appeal to the king, even resort to tears, in order to save her people:

\author{
¿Así remedias \\ la ruina y eversión del Pueblo Hebreo? \\ ¿Así Raquel, redimes las miserias \\ de tu infeliz Nación? (2.1-5)
}

3. All citations in this study will come from Gordis' edition of Esther which contains both the Hebrew text and an Enghish translation. The citations will be listed by chapter and verse number. 
Del indignado Alfonso en la presencia, las perlas que aquí viertes sin provecho de nuestra libertad rescate sean $(2.32-34)$

In doing so she ultimately risks her own fate, as Esther did. If they do not follow their counselor's advice both heroines must resign themselves to play insignificant roles in the story. Esther will go on being a part of the king's harem and Raquel will be exiled. Yielding to the counselor's advice is the cause of happiness in Esther and tragedy in Raquel.

We also see another similarity in the advice given to the heroines. In trying to convince Esther that she must act Mordecai states: "And who knows whether it was not for a time like this that you have attained to royal estate?" (4.14). In other words Mordecai's message to Esther is that she should take advantage of the situation (the favor Ahasuerus has shown her) in order to reap the benefits (the salvation of the Jews). Rubén gives a similar message to Raquel. He tells her, "delirio es de tu amor tal pensamiento;/ recobra la esperanza, y aprovecha, si quieres remediar el mal presente" (2.107-09). Like Mordecai, Rubén wants Raquel to capitalize on an opportune moment.

Both heroines must also hope that they continue to appeal to the king as they have in the past. Only then can they be successful. Before seeing the king each woman feels she has lost some of this appeal. Esther is not sure whether it is the right time to visit Ahasuerus because she has been all but fogotten at the court:

All the king's servants and the people of the king's provinces know that for any man or woman who comes to the king to the inner court without an invitation, there is only one law - death - unless the king extends to him his golden scepter; only then he may live. As for me, I have not been called to come to the king these last thirty days. (4.11)

Rather than being executed she receives a favorable greeting by a king who, out of love for his queen, is prepared to offer her whatever she wants:

When the king saw Queen Esther standing in the courtyard, she won his favor...Then the king said to her, "What is troubling you, Queen Esther, and what is your petition? Be it half the kingdom, it will be granted to you!" $(5.2-3)$

Similarly, Raquel finds it difficult to accept Rubén's position because she has been scorned by Alfonso: "Alfonso, el mismo Alfonso me condena;/ de su boca, Rubén, de mi destierro/ he escuchado yo mismo la sentencia" (2.56-58). Yet Raquel is equally successful in her appearance before the king when Alfonso gives her power to rule over his lands: "sabed que hoy en mi Trono 
substituyo/ a Raquel; mi poder y mi dominio/ la transfiero" (2.669-71).

Neither woman finds as easy way out. In reality they have little choice but to accept the advice that is given. Mordecai warns Esther of the consequences of not acting: "For if you remain silent at this time, relief and deliverance will arise for the Jews from another quarter, but you and your father's house will be destroyed" (4.14). As Rubén relates, Raquel must intercede or disaster will result:

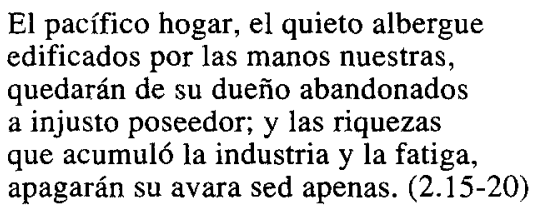

In both works we see three characters connected in such a way that they share the blame for what occurs. In Esther the king, queen, and counselor demonstrate this type of affiliation. Mordecai, as we have seen, is the one who advises Esther to approach the king. He is the one who incites her towards her destiny. Ahasuerus helps Esther reach her goal by not stopping her in her effort to terminate the plot against the Jews. Therefore, both male characters are essential in the development of the plot as the heroine's success depends in large part on their activity (or, in Ahasuerus' case, his inactivity).

Donald E. Schurlknight has written that, "todos tres -Raquel, Alfonso, Rubén - son responsables de la tragedia" (1981, pág. 77). Just as Mordecai's advice pushes Esther into her role as savior of the Jews, Rubén is responsible for the tragic situation into which Raquel falls as he teller her: "Estas son las funestas consecuencias,/ que por más que esforzaba el artificio,/ temí de mi ambición y tu soberbia" (3.396-98). Of course, the significant difference is that while Esther is able to save her life, Raquel is not so fortunate. Alfonso is like Ahasuerus in that he is directly responsible for the final consequences because he gives in to Raquel's request. While it is true that Esther benefits, and Raquel suffers, the act of giving in makes each king an unknowing participant. In Act Three, upon lamenting the death of Raquel, Alfonso says: "Yo tu muerte he causado, Raquel mía" (775). By conceding, Ahasuerus has saved Esther's life, while Alfonso's similar act has ended the life of Raquel. However, in both cases conceding to the wishes of the heroine has played an extremely significant role in the story.

In Esther, Haman is responsible for bringing on his own downfall. Even after Esther has exposed Haman's plot to Ahasuerus, it is not until the villain incriminates himself that his fate is sealed. Ahasuerus decides that Haman must die, not because he has been informed of his plot against the Jews, but because 
he finds Haman in a compromising position with the queen (Chap. 7). Actually, the King encounters Haman while he is begging forgiveness of Esther and interprets Haman's actions as being amorous advances towards the queen. Unfortunately for Haman, he has trapped himself and will soon meet with death.

Until now we have focused on the parallel between Rubén and Mordecai and their role as counselors. Of course, this resemblance ends when we consider their overall roles in the play. Mordecai is virtuous while Rubén is always viewed as being the most villainous character in Raquel. Therefore, in a comparison of Esther and Raquel, it is fitting that the most wicked character in each work meets his fate in a similar manner, and therefore we must now compare Haman and Rubén. Rubén is not killed by the citizens or the noblemen when his wickedness is exposed. Rather he, like Haman, incriminates himself when he kills Raquel. He does so because Alfonso enters and wrongly assesses the situation. Just as Ahasuerus does not realize that Haman is only trying to save himself by speaking with Esther, Alfonso does not truly know why Rubén has killed Raquel. Although his action certainly demonstrates his disloyalty, it is nonetheless true that the only way in which Rubén can save himself is to kill Raquel: "Pues si no hay medio,/ conserve yo mi vida, y Raquel muera" (3.673-74). Rubén shares a common motive with Haman, the motive of self-preservation, which leads to tragedy in both cases when the king acts, albeit rightly, without knowing all the facts.

Having reviewed the plot similarities between Esther and Raquel let us examine the similarities between the characters of the two works. This will lend additional credence to the theory that Esther was one of Huerta's two major sources. We will focus on the parallels between Esther and Raquel and those between King Alfonso and King Ahasuerus.

Aside from being the heroines of their respective stories Esther and Raquel share various qualities. First, they are motivated to act for similar reasons. Esther risks her life because she must come to the aid of her people. She does not become queen because she wants to save the Jews; rather she is obligated to do so after learning of Haman's plot from Mordecai. As we have seen, she approaches Ahasuerus, not out of any personal interest but because she realizes her people are in danger.

In Raquel, the heroine is also inspired to aid the Jewish people: " $\mathrm{Y}$ los Hebreos/ que no tienen, Señor, otro delito/ que depender de mí?" (2.643-45). Though she is also motivated by her love for Alfonso, the motivation to save the Jews certainly plays a role, as Monroe A. Hafter has noted: "Rubén speaks movingly of the suffering of their countrymen, and urges Raquel to exploit the advantages offered by Alfonso's strong love for her" (1985, pág. 222). 
Another very interesting comparison comes to light when we consider that both heroines come to occupy a high royal office without having been born into the nobility. In his introduction to Esther, Robert Gordis explains that because Esther lived in Persia she had absolutely no right to become queen because "Persian queens had to come from one of seven noble Persian families" (1974, pág. 8). The only reason Esther becomes queen is because of Ahasuerus' instant attraction for her:

the king loved Esther more than all the other women, for she won his favor and kindnes more than all the other virgins. So he placed the royal crown upon her head and made her queen instead of Vashti. (2.17)

Raquel, though not a member of the nobility, is also bestowed with royal powers when she receives Alfonso's crown and scepter. Like Esther she is elevated to this position because of Alfonso's overwhelming love for her:
Y porque tu temor desvanecido del todo quede; porque no receles de un vulgo osado los infieles tiros, desde hoy de mi Cetro y mi Corona serás dueño absoluto. Mis dominios a tu arbitrio se rijan y gobiernen. (2.646-51)

Juan A. Ríos Carratalá has attempted to de-emphasize Raquel's qualities as a heroine and has given Hernán García the principle role in the tragedy (1987, págs. 99-100). However, Professor Sebold has clearly demonstrated how Huerta was making a comment on the contemporary concept of nobility when he caused Raquel to say: "la virtud solamente es la nobleza" (3.320). According to Sebold, Raquel is a true tragic heroine because she is a result of the "perenne adaptabilidad de las formas clásicas" (1989, pág. 312). In his effort to criticize the nobility, Huerta could easily have turned to Esther as a model of a virtuous woman who, in rising from the common class to become queen, demonstrates valor by risking her life to save her people.

A strong parallel may also be found btween King Ahasuerus and King Alfonso. In Esther Ahasuerus is a man who is conspicuously uninvolved when important decisions are made and permits events to proceed without intervening. Haman is able to conceive the eventual massacre of the Jews by convincing Ahasuerus that the Jews are a threat and by obtaining the royal seal to issue his decrees (Chap. 3). The story continues in Haman's favor until Esther is able to appeal to the king's emotions and persuade him to hold two banquets, which is part of her plan to trap Haman (Chaps. 5-6). Ahasuerus never realizes what is going on and acts like a secondary character when major events occur. Ahasuerus is a weak character, but this weakness is essential to the plot because if he were stronger and did not let Esther appeal to his emotions, the heroine would never 
have met with success. Overall, Ahasuerus remains in the background serving more as a symbol of a monarch rather than as the ruler of an empire. At times he has even been taken for a fool (Berg, 1979, pág. 63). His character is certainly a far cry from the monarch he is supposed to represent, the great Persian King Khshayarsha (known by the Greeks as Xerxes) (Gordis, 1974, pág. 5).

Alfonso is equally weak. He is unaware of the plot against Raquel and leaves for a hunting trip when the situation comes to a boiling point. The play continues whithout him until he walks in after it is too late. It is interesting to note that in creating Alfonso as a weak character Huerta departed from one of the other versions of the Judia de Toledo, Luis de Ulloa's poem Raquel. According to Ríos Carratalá:

En la obra de Huerta el monarca, sumido en su función simbólica, cambia muy superficialmente de actitud con respecto a su amada, sin mostrarnos la más mínima profundidad psicológica. Pero en Ulloa AIfonso VIII sufre intensamente ante la presión de elementos tan contradictorios. (1987, págs. 83-84)

Alfonso's weakness, like that of Ahasuerus, has an important function in the story. If he had not given in to Raquel, and conferred upon her the power to be queen, she would probably not infuriate the noblemen to the point where they are ready to murder her. Like Ahasuerus, the Alfonso of Raquel is a shadow of his historical counterpart, who was "once the heroic victor of Las Navas de Tolosa and other campaigns" (Hafter, 1985, pág. 119). René Andioc has defined Alfonso's reign in Raquel as one which "excluye toda referencia a leyes fundamentales, tiene como único motor las pasiones que esclavizan al que gobierna -pasiones simbolizadas en este caso por el dominio de Raquel sobre su real amante-_" (1975, pág. 131). This reminds us very much of Ahasuerus' reign, in which the fate of an entire people depends on the influence Esther is able to exert over him. Both monarchs are ultimately ruled by their profound love for women who have acquired the power to reign over their respective kingdoms.

There is certainly much evidence to support the theory that Huerta was influenced by Esther. However, even if he was not directly familiar with the biblical text Huerta would still have had various opportunities to learn of the story because "el tema de la reina Ester se ha tratado en numerosas ocasiones a lo largo de nuestra historia [española]" (Bolaños Donoso, 1983, pág. 290) ${ }^{4}$. The Esther theme was introduced into Spanish literature in 1576 when the Auto de Mardoqueo was staged in the colegio de los Jesuitas de Gran Canarias. The story was retold by the Golden-Age dramatist Lope de Vega in 1610 when he wrote La hermosa Ester.

4. For an analysis of the Esther tradition in Spanish Literature see Bolaños Donoso (1983, págs. 290-94). 
In 1613 Felipe Godínez wrote La reina Ester. He later wrote a similar play called Amán y Mardoqueo (which is also known as La horca para su dueño). In 1627 Joan Pinto Delgado wrote a poem called Reina Ester. The tradition was continued by others, including Racine, in his Esther (1689), with which Huerta may well have been acquainted, as well as by Juan Climaco Salazar with his poem Mardoqueo in 1791; and the theme was utilized several more times in the nineteenth century (Bolaños Donoso, 1983, págs. 290-94).

It is intriguing to consider the direct influence these works may have had on Huerta. But is also important to note that they do not distort any of the important aspects of the original story that is interpreted in Huertas's work. In any case, we can draw a distinct parallel between the Esther theme, as it is represented in the Golden Age, and Raquel. In the Old Testament, the story continues after the death of Haman to include descriptions of how Mordecai rose to occupy Haman's old position and how the Jewish festival of Purim was subsequently established in order to commemorate the failure of Haman's plot (Chaps. 9-10). However, Lope and Godínez omitted these final chapters and, instead, finish with the scene in which Haman is killed (Bolaños Donoso, 1983, pág. 293). In this respect Huerta's play, in whose last scene Rubén and Raquel are killed, reminds us of the Esther works that end with the death of the most villainous character. In addition, in her analysis of Godínez' Amán y Mardoqueo, Piedad Bolaños Donoso demonstrates how the work contains an alternating emphasis on amorous and political themes, with Act Three being dedicated almost entirely to political matters (1983, pág. 285-86). This emphasis on the political may have served as a model to Huerta when he decided to incorporate current eighteenth-century political themes into Raquel.

I can suggest one more important proof of Huerta's knowledge of the Esther story. In his Teatro Español (1785), Huerta lists Lope's play, La hermosa Ester, and was also aware of both of the works Godínez had written (Vega García-Luengos, 1986, pág. 74) ${ }^{5}$. Therefore, we are certain that Huerta was directly familiar with the theme, a fact which lends a great deal of credence to the theory that the Esther story was one of his main sources.

The evidence we have uncovered has afforded us the opportunity to draw a new conclusion concerning the sources of Raquel. In designing the story of his tragedy Huerta relied upon other works that had dealt with the legend of the Judia de Toledo. After the Judia de Toledo, as the striking parallels between Raquel and Esther prove, Esther was Huerta's next most important source. Raquel is at one and the same time a continuation of the Esther tradition and the Spanish tradition announced in Huerta's title.

5. For more detailed explanations of what Huerta knew of Godinez see Vega García-Luengos (1986). 


\section{WORKS CITED}

ANDIOC, René. 1975. "La Raquel de Huerta y la censura", Hispanic Review, 43, págs. 115-139.

- (ed.) 1987. Introduction and notes. Raquel, Madrid, Castalia.

BERG, Sandra Beth. 1979. The Book of Esther: Motifs. Themes and Structure, Missoula, Scholars.

BOLAÑOS DONOSO, Piedad. 1983. La obra dramática de Felipe Godínez (trayectoria de un dramaturgo marginado). Sevilla, Excma. Diputación Provincial.

GORDIS, Robert. 1974. Introduction, translation and commentary. Megillat Esther, New York, Ktav.

HAFTER, Monroe Z. 1985. "Remedial Action in Huerta's Raquel". Studies in Honor of Sumner M. Greenfield. Ed. H. L. BOUDREAU and Luis T. GONZALEZ DEL VALLE, Lincoln, Society of Spanish and Spanish-American Studies.

JOHNSON, Jerry L. 1972. The Relevancy of La Raquel to its Times", Romance Notes, 14, págs. 86-91.

RÍOS CARRATALÁ, Juan A. 1986-87. "Versiones decimonónicas de la leyenda de la Judía de Toledo", Anales de Literatura Española, 5, págs. 425-36.

—. 1987. Vicente García de la Huerta (1734-1787), Badajoz, Aprosuba.

SCHURLKNIGHT, Donald E. 1981. "La Raquel de Huerta y su sistema particular", Bulletin Hispanique, 83, págs. 65-78.

SEBOLD, Russell, P. 1989. "Neoclasicismo y creación en la Raquel de García de la Huerta". El rapto de la mente, 2nd ed. Barcelona, Anthropos, págs. 303-318.

SEGURA COVARSÍ, Enrique. 1951. "La Raquel de García de la Huerta", Revista de Estudios Extremeños, 1-2, págs. 197-234.

VEGA GARCÍA-LUENGOS, Germán. 1986. Problemas de un dramaturgo del Siglo de Oro. Estudios sobre Felipe Godínez, Salamanca, Kadmos. 


\title{
ASPETTI DELLE TEORIE ROMANTICHE INGLESI IN CERNUDA
}

\author{
Renata LONDERO \\ Università di Udine
}

Nell'esteso saggio autobiografico Historial de un libro - La Realidad y el Deseo, che ripercorre le tappe essenziali della sua formazione culturale e poetica, Luis Cernuda mette in risalto l'importanza che rivestì per lui l'incontro con la letteratura inglese. In uno dei passi più significativi si legge:

Aprendí mucho de la poesía inglesa, sin cuya lectura y estudio mis versos serían hoy otra cosa, no sé si mejor o peor, pero sin duda otra cosa. Creo que fue Pascal quien escribió: "no me buscarías si no me hubieras encontrado", y si yo busqué aquella enseñanza y experiencia de la poesía inglesa fue porque ya la había encontrado, porque para ella estaba predispuesto. (Cernuda, 1975, pág. 921)

Il contatto letterario di Cernuda con la cultura anglosassone coincide cronologicamente con l'inizio del suo quasi decennale esilio volontario in Gran Bretagna (1938-1947) ${ }^{1}$, e prosegue poi, a varie riprese, durante il soggiorno negli Stati Uniti, pressoché ininterrotto dal 1947 al 1963. Ma l'interesse del poeta spagnolo per la letteratura inglese era sorto in precedenza ed è già riscontrabile nella raccolta Invocaciones (1934-1935) e in alcuni saggi critici apparsi nel 1935, tra i quali è assai interessante "Palabras antes de una lectura".

Tuttavia, solo a partire dal 1938 , Cernuda comincia a leggere e a studiare con sistematicità e costanza gli autori inglesi da lui più apprezzati e sentiti più congeniali ${ }^{2}$.

1. Per un accurato e dettagliato resoconto della vita inglese di Cernuda, si veda il libro di Rafael Martínez Nadal (1983) corredato di un gran numero di lettere inviate da Cernuda all'autore, alle amiche Nieves Mathews e Rica Brown, oltre che al professor Edward M. Wilson.

2. Dati interessanti sull'approfondita lettura di molti poeti e critici inglesi in questo periodo sono attestati dall'epistolario. Illuminanti, a questo riguardo, sono le lettere al professore 
Del resto, per valutare appieno il peso di questa cruciale esperienza letteraria nell'opera di Cernuda, è sufficiente considerare in quante direzioni si rivolga il suo studio appassionato della letteratura inglese, e in particolare degli autori del XIX e XX secolo: traduzioni, prosa critica, produzione in versi.

Le versioni dall'inglese allo spagnolo non sono numerose, ma di gran pregio: in un lungo arco di anni, dal 1938 al 1962 circa, il sivigliano traduce liriche di Andrew Marvell, William Blake, William Wordsworth, Robert Browning e William Butler Yeats ${ }^{3}$, e due drammi di William Shakespeare, Troilus and Cressida e Romeo and Juliet (di quest'ultima soltanto il primo atto).

Del tutto singolare nel panorama della critica spagnola contemporanea è la raccolta di saggi critici Pensamiento poético en la lírica inglesa - Siglo XIX, scritta nel 1958, a riassumere un ventennio di assidua e feconda frequentazione della letteratura inglese, con speciale riferimento all'Ottocento. L'opera, divisa in due parti (I, 1800-1830; II, dal 1830 alla fine del secolo), dà prova delle letture poetiche e critiche di Cernuda riguardanti il Romanticismo e l'epoca vittoriana. In particolare, la prima sezione, riservata ai romantici inglesi che più interessarono e affascinarono Cernuda, è preceduta dall'excursus "Fondo histórico del Romantic Revival" e s'articola in cinque capitoli, "William Blake", "William Wordsworth", "Samuel Taylor Coleridge", "Percy Bysshe Shelley", "John Keats", che dimostrano come Cernuda non solo conobbe in profondità la produzione in prosa e in versi degli autori citati, ma ebbe anche dimestichezza con i maggiori interventi critici ad essi dedicati (per esempio, la monografia Wordsworth di Herbert Read; il libro di I. A. Richards, Coleridge on Imagination, e The Road to Xanadu di J. L. Lowes, sulla concezione dell'immaginazione e la poesia di Coleridge; la biografia di Keats scritta da Richard Monckton Milnes, The Life and Letters of John Keats).

D'altra parte, è la lirica il genere in cui Cernuda si rapporta più direttamente e più acutamente alla letteratura inglese: le raccolte dove questa relazione (soprattutto con i romantici e con Browning, Yeats e T. S. Eliot) ${ }^{4}$ è maggiormente

anglocolombiano Edward Sarmiento, raccolte da James Valender (1979). Un quadro preciso delle letture inglesi di Cernuda è fornito da Eugenio Suárez-Galbán Guerra (1985). Il ruolo fondamentale che il contatto con la letteratura anglosassone giocò nell'opera di Cernuda, comunque, è messo in luce da alcuni dei suoi più insigni studiosi, quali Octavio Paz (1964), Carlos Peregrín Otero (1963; 1982) e Derek Harris (1973).

3. Sulle traduzioni cernudiane dei poeti inglesi, di ottima fattura, pochi critici si sono soffermati: fa eccezione l'analisi puntuale di Bernd Dietz (1979).

4. Sull'assorbimento cernudiano del monologo drammatico di Browning, noché delle teorie poetiche di Yeats ed Eliot, si concentra John Alexander Coleman nella sua monografia (1969). Confronti tematici stimolanti tra l'ultima produzione di Cernuda e l'opera di Eliot sono stati proposti da Catherine Bellver (1983) e da Fernando Ortiz (1985). Una buona visione d'insieme sull'argomento è in B. Hughes (1988). 
evidente sono Las nubes (1937-1940) e Como quien espera el alba (1941-1944), ma esempi altrettanto apprezzabili si ritrovano pure nelle collezioni successive, Vivir sin estar viviendo (1944-1949), Con las horas contadas (1950-1956), e Desolación de la quimera (1956-1962).

La poetica di Cernuda, quale si enuclea dalla lettura delle sue opere, sostanzialmente autobiografiche e individualistiche, è in prevalenza di stampo neoromantico ${ }^{5}$. I suoi temi principali sono la solitudine, l'amore il trascorrere del tempo, l'incombere della morte, l'approccio panteistico alla natura, il contrasto tra "realidad" e "deseo" —realtà quotidiana e illusione—, la nostalgia della patria lontana, il conflitto del poeta con la società ostile.

Particolarmente avvincente appare, dunque, il confronto tra Cernuda e i romantici inglesi, qualora si pensi alla natura neoromantica del poeta sivigliano e al valore della sua scoperta della letteratura anglosassone. Il rapporto che Cernuda instaurò con i poeti romantici inglesi produsse, infatti, l'assorbimento e l'originale riutilizzazione di temi e motivi comuni, nella sua produzione in versi e in prosa.

Tale rielaborazione si rivela in special modo fruttifera, infine, quando ci si soffermi su un aspetto dominante del pensiero cernudiano: la definizione, che fu sempre urgente in lui, della missione del poeta, della sua posizione nella società, e del ruolo che la poesia svolge tra gli uomini e per gli uomini.

Per quanto concerne il tema metapoetico, Cernuda istituì con $\mathrm{i}$ poeti romantici inglesi un nesso di tipo interdiscorsivo, secondo la definizione di Cesare Segre:

Per i rapporti che ogni testo, orale o scritto, intrattiene con tutti gli enunciati (o discorsi) registrati nella corrispondente cultura e ordinati ideologicamente, oltre che per registri e livelli, proporrei di parlare di interdiscorsività. (Segre, 1984, pág. 111)

Egli, cioè, riformulò paradigmi collettivi del Romanticismo anglosassone cui diedero espressione tutti i suoi massimi rappresentanti: Wordsworth, Coleridge, Keats e Shelley; tra loro Cernuda inserì anche l'eccezionale figura di Blake; escluse, invece, Byron, troppo distante dalla sua concezione poetica.

I temi generali a cui il sivigliano si richiama sono la funzione capitale conferita all'immaginazione, grazie alla quale il poeta può trascendere i limiti dell'esperienza ordinaria, per cogliere un ordine diverso e arcano; la

5. Quanto al "neoromanticismo" di Cernuda, i suoi esegeti continuano a schierarsi su posizioni largamente discordanti. In un ciclo di conferenze lette alla Fundación Juan March di Madrid, Philip Silver ha cercato di fare il punto sulla vexata quaestio, sottolineando l'anti-ispanismo del "romanticismo" cernudiano, più vicino, piuttosto, alle correnti filosofiche anglo-germaniche del Sette-Ottocento (1989). 
considerazione della creazione poetica come efetto della costrizione operata sull'artista da una forza ignota, irresistibile, che lo obbliga a plasmare il suo eterocosmo in uno stato di estasi; la glorificazione del poeta-vate, creatura solitaria e divina, dotata di virtù straordinarie e circondata da un'aura sacrale.

Giustificano l'assunzione di questi temi da parte di Cernuda non solo la sua ammirazione per $\mathrm{i}$ romantici inglesi, ma soprattutto la concezione neoromantica del ruolo del poeta e della poesia. La scrittura poetica fu, infatti, valore supremo della sua opera e della sua stessa vita, "fue para Cernuda el único y verdadero amor: el más sublime y absorbente. A ella dedicó lo mejor de su existencia. En ella encontró redención y compensación a sus angustias y frustraciones humanas" (Couso Cadahya, 1976, pág. 33).

É da tener presente, comunque, che Cernuda non sviluppò mai una precisa teoria dell'immaginazione, né s'abbandonò a quei voli della fantasia e a quei viaggi visionari che costituiscono il grande fascino di molta poesia romantica inglese: il sivigliano trasse dagli scritti teorici e dai componimenti in versi dei romantici solo gli spunti tematici che potevano essergli utili per tracciare la propria concezione della poesia, pur sempre di netta impronta neoromantica.

\section{Il ruolo dell'immaginazione}

\section{L'intuizione di una realtà trascendente}

Nelle pagine introduttive a Pensamiento poético en la lírica inglesa, il cui argomento principale ruota intorno a "las ideas que acerca de la poesía expusieron los poetas ingleses" ("Prefacio", in Cernuda, 1975, pág. 487), Cernuda mette in rilievo la caratteristica, secondo lui più saliente, del movimento romantico inglese, "el papel que [...] desempeña la imaginación" (ibíd., pág. 504). Questa facoltà è provvista di una eccezionale capacità creativa che la colloca all'apice di tutti i poteri dell'intelletto, ed è quindi responsabile della scoperta di un mondo invisible ai più, posto al di là della normale esperienza umana. I poeti romantici inglesi

creían en un orden transcendente, que no es el orden de lo que vemos y sabemos; y descubrir ese orden era la meta de su poética, buscando cómo penetrar en otra realidad que no fuese la cotidiana, explorarla y, de ese modo, comprender lo que nuestra vida significa y lo que vale. (ibíd., pág. 504)

Testimonianze della fruttuosa ricezione cernudiana di questo paradigma del Romanticismo inglese sono osservazioni molto simili, presenti sia nell'opera in prosa che nel corpus lirico (a partire da Invocaciones), e riferite all'intuizione di un mondo altro - conoscibile esclusivamente grazie al dono dell'immaginazione-, di una "superior, invisible reality lying behind the illusory appearance of the world" (Harris, 1973, pág. 97). 
Il concetto di /esperienza poetica / = / conquista dell'essenza divina del mondo / è chiaramente enunciato in tre poemi in prosa di Ocnos, "La poesía", "Pantera" e "El acorde".

$\mathrm{Ne}$ "La poesía", Cernuda ricorda come, sin dalla prima infanzia, egli abbia identificato la visione immaginativa con la percezione degli aspetti più misteriosi del creato:

Entreví entonces la existencia de una realidad diferente de la percibida a diario, y ya oscuramente sentía cómo no bastaba a esa otra realidad el ser diferente, sino que algo alado y divino debía acompañarla y aureolarla, tal el nimbo trémulo que rodea un punto luminoso. (ibíd., pág. 19)

La pantera dell'omonimo poema in prosa è un animale crudele e inquietante che pare provenire da un' altra dimensione, e nei cui occhi brilla minaccioso un lampo di luce (cfr. il "glittering eye" dell "Ancient Mariner" di Coleridge, o il fuoco che brucia nello sguardo della "tyger" di Blake, a cui probabilmente Cernuda si rifece per la composizione di questo brano). La splendida bestia, prigioniera tra le sbarre di una gabbia, sembra volersi rifugiare in "otra realidad que los sentidos no vislumbran [...] más allá de la apariencia” (ibíd., pág. 74).

$\mathrm{Ne}$ "El acorde", il poeta descrive un'esperienza di armonizzazione con la natura, che si configura nel distacco dalla sfera materiale e nel raggiungimento degli oscuri recessi dell'essere, ed è ottenuta tramite l'estasi sessuale (elemento specificamente e inconfondibilmente cernudiano). Il balzo da un piano all'altro del reale è attuabile, dunque, solo nel momento in cui avviene la fusione fisica con il "cuerpo deseado":

todo está abierto: un arco al espacio ilimitado, donde tiende sus alas la leyenda real. Por ahí se va, del mundo diario, al otro extraño y desusado [...] tu experiencia, tu acorde místico, comienza como una prefiguración sexual. (ibíd., págs. 103-104)

Vero e proprio testo metapoetico, programmatico, è "Palabras antes de una lectura", in cui Cernuda dà la sua interpretazione dell'equivalenza romantica tra visione immaginativa e recupero di una diversa esistenza (durante la creazione l'artista può "alcanzar alguna vislumbre de la imagen completa del mundo que ignoramos, de la idea divina del mundo que yace al fondo de la apariencia, según la frase de Fichte"; (ibíd., pág. 872). Il suo desiderio di scalvacare le barriere del quotidiano, infatti, è dovuto alla volontà di sanare la disparità lacerante tra "realidad" e "deseo", che permea tutto il suo universo lirico:

El deseo me llevaba hacia la realidad que se ofrecía ante mis ojos como si sólo con su posesión pudiera alcanzar certeza de mi propia vida. Mas como esa posesión jamás la he alcanzado sino de modo precario, de ahí la corriente contraria, de hostilidad ante el irónico atractivo de la reali- 
dad [...] la realidad exterior es un espejismo y lo único cierto mi propio deseo de poseerla. (ibíd., pág. 872)

La frustrante routine di ogni giornno è solo apparenza, mentre la vera realtà è quella che egli si costruisce personalmente e che corrisponde al suo "deseo" omosessuale. Due esemplificazioni di tale teoria sono contenute in Historial de un libro ("sólo he tratado [...] de hallar mi verdad, la mía, que no será mejor ni peor que la de los otros, sino sólo diferente"; (ibid., pág. 937) e nel saggio "El espíritu lírico", dove Cernuda generalizza il suo pensiero, abbozzando la figura universale del poeta, sempre alla ricerca di una "realidad suya" (ibíd., pág. 1246).

Nel corpus lirico, Cernuda sostiene che soltanto il poeta è in grado di scorgere il mondo invisibile al di là della realtà esperibile con i sensi:

Cómo va nuestra fe hacia las cosas

Ya no vistas afuera con los ojos,

Aunque dentro las ven tan claras nuestras almas;

("Retrato de poeta", vv. 35-37; in Con las horas contadas,

Cernuda, 1974, pág. 420).

Molto suggestivi sono pure i luoghi percorsi dal poeta ispirato in "Himno a la Tristeza" (Invocaciones; in Cernuda, 1974, pág. 198):

Mientras sus nombres suenan

Con el viento en las rocas,

Entre el hosco rumor de torrentes oscuros,

Allá por los espacios donde el hombre

Nunca puso sus plantas.

(vv. 54-58)

Non a caso questi versi riecheggiano la simbolica descrizione del "deep romantic chasm" (v. 12) -prorompere tumultuoso del fiume sotterraneo in superficie, rocce che s'affacciano sull'abisso- nel "Kubla Khan" di Coleridge (in Coleridge, 1985, págs. 102-104):

And from this chasm, with ceaseless turmoil seething,

As if this earth in fast thick pants were breathing,

A mighty fountain momently was forced:

Amid whose swift half-intermitted burst

Huge fragments vaulted like rebounding hail,

Or chaffy grain beneath the thresher's flail:

And 'mid these dancing rocks at once and ever

It flung up momently the sacred river.

(vv. 17-24)

o l'immagine presentata da Keats in "Ode to a Nightingaie", che completa 
la raffigurazione fantastica del mondo dell'usignolo, già delineata nella quinta strofa:

Charmed magic casements, opening on the foam

Of perilous seas, in faery lands forlorn.

(vv. 69-70; in Keats, 1973, pág. 347)

Cernuda non riutilizzò le varie interpretazioni che dell'immaginazione proposero singolarmente Blake, Wordsworth, Coleridge, Keats e Shelley, sebbene le avesse ben presenti alla mente, da quanto si deduce dalle cospicue citazioni in Pensamiento poético en la lírica inglesa, dove egli riporta in traduzione ampi stralci di importanti testi metapoetici del Romanticismo inglese, quali la Biographia Literaria di Coleridge e la Defence of Poetry di Shelley, nonché le definizioni della natura dell'immaginazione e della poesia espresse nelle lettere di Keats, nei saggi critici di Wordsworth e in vari testi in prosa di Blake. Se è vero, comunque, che Cernuda adattò alla propria concezione del conflitto realtà/desiderio il paradigma romantico dell' immaginazione vista come veicolo per raggiungere il nucleo del creato, ciò non toglie che il poeta spagnolo dovette ben ricordare quelle letture, come risulta evidente qualora si paragonino i suoi testi sopraesaminati con alcuni passi degli autori inglesi citati. Del resto, la tendenza verso una realtà che varca i confini del mondo sensibile è componente tematica centrale, presente in tutti i maggiori poeti romantici anglosassoni: "the creative imagination is closely connected with a peculiar insight into an unseen order behind visible things" (Bowra, 1961, pág. 271).

Nel commento a un suo dipinto, "A Vision of the Last Judgment", annotato nel Notebook del 1810 (e che Cernuda cita in "William Blake", Pensamiento poético en la lírica inglesa; Cernuda, 1975, pág. 514), Blake dichiara l'effettiva presenza di un mondo fantastico ultrasensibile, le cui qualità precipue sono l'eternità e la sacralità:

Vision or Imagination is a Representation of what Eternally Exists, Really \& Unchangeably [...] This world of Imagination is the world of Eternity; it is [...] Infinite \& Eternal [...] There Exist in that Eternal World the Permanent Realities of Every Thing which we see reflected in this Vegetable Glass of Nature. (Blake, 1966, págs. 604-605)

In "Jerusalem", Blake conclude che il ruolo del poeta-profeta é quello di

To open the Eternal Worlds, to open the immortal Eyes

Of Man inwards into the Worlds of Thought: into Eternity

(Chapter I, Plate V, vv. 18-19; in Blake, 1966, pág. 623).

Cosí tratteggia Wordsworth l'attimo dell'illuminazione nel Book VI del Prelude: 


\section{$[\ldots]$ in such strength}

Of usurpation, when the light of sense

Goes out, but with a flash that has revealed

The invisible world, doth greatness make abode,

There harbours; [...]

(vv. 599-603; in Wordsworth, 1904, pág. 535).

Nel Book XIV, al poeta è attribuita la facoltà di entrare in comunicazione con il misterio del mondo, egli è "a mind"

That feeds upon infinity, that broods
Over the dark abyss, intent to hear
Its voices issuing forth to silent light
In one continuous stream; a mind sustained
By recognitions of transcendent power,
(vv. 71-75; in Wordsworth, 1904, pág. 584).

Nel suo trattato platonicheggiante, Defence of Poetry, Shelley afferma che "A poem is the image of life expressed in its eternal truth" (Shelley, 1909, pág. 128 ), e che il grande poeta scorge attraverso il velo della realtà materiale le forme eterne che popolano il regno superiore delle essenze; la poesia "strips the veil of familiarity from the world, and lays bare the naked and sleeping beauty, which is the spirit of its forms" (ibid., pág. 155).

Anche per Keats, in cui, tuttavia, il superamento dei limiti della realtà sensibile non è mai totale e assoluto (cfr. la lirica "Lines Written in the Highlands after a Visit to Burns's Country", in cui egli teme che un uso indiscriminato della "visionary imagination" lo possa condurre alla follia), la poesia è un mezzo per carpire verità altrimenti indecifrabili, è "a fine isolated verisimilitude caught from the Penetralium of mystery" (lettera a George e Tom Keats del 27 dicembre 1817; in Keats, 1958, pág. 194). E ancora, nel terzo libro dell'Hyperion, Apollo confessa a Mnemosyne che l'incanto del mondo naturale gli fa supporre l'esistenza di un mondo celeste di immutabile bellezza:

Goddess benign, point forth some unknown thing:

Are there not other regions than this isle?

What are the stars? There is the sun, the sun!

And the most patient brilliance of the moon!

And stars by thousands! Point me out the way

To any one particular beauteous star,

And I will flit into it with my lyre,

And make its silvery splendour pant with bliss.

(vv. 95-102; in Keats, 1973, págs. 305-306)

\section{Il "poder daimónico", il "divinus furor"}

All'esaltazione dell'immaginazione è strettamente collegato il concetto 
d'ispirazione poetica, che in Cernuda (come nei romantici inglesi da lui prediletti) corrisponde a un'ondata che investe il poeta, inducendolo a scrivere in uno stato di estasi iniziatica. Questa inesorabile potenza che sveglia nell'artista l'impulso a comporre, è denominata da Cernuda "poder daimónico o demoníaco", definizione che -come egli stesso puntualizza in "Palabras antes de una lectura"- ha letto nei Gespräche mit Goethe di Eckermann, con riguardo proprio alla componente irrazionale dell' invenzione poetica. La poesia, dunque, è mossa da tale potere, ne è l'inconsapevole espressione:

la poesía $[\ldots]$ no es sino expresión de esa oscura fuerza daimónica que rige el mundo. [...] No se me pregunte más sobre ese poder, porque nada sabría decir. Lo presiento, pero no lo comprendo. Además, ¿cómo expresar con palabras cosas que son inexpresables? (Cernuda, 1975, págs. 875-876).

Il medesimo concetto ricompare ne "La escuela de los adolescentes", articolo scritto nel 1931 (la data stessa è indizio del fatto che il tema della creazione inconsapevole è originale in Cernuda, benché appaia sviluppato più ampiamente negli anni inglesi): "Hay un poder demoníaco, no sé si ajeno o no a nosotros mismos, que actúa y dispone nuestro rumbo con arreglo a un secreto destino". (ibid., pág. 1236)

Il prorompente impeto creativo si converte perfino in una necessità inderogabile, una spinta fatale che lo assoggetta totalmente: l'artista, cioè, si sente "poseído por un fatum trágico, y por él condenado a escribir necesariamente aquello que por necesidad vital es preciso escribir". (Talens, 1975, pág. 163). Se, infatti, più volte Cernuda constata che il poeta "tiene una razón fatal, anterior a su propia existencia y superior a su propia voluntad, que le lleva a escribir versos" ("Poesía popular", in "Poesía y Literatura I"; Cernuda, 1975, pág. 729), talvolta giunge al punto di agognare la morte, per sottrarsi a una simile coercizione:

Para el poeta la muerte es la victoria;

Un viento demoníaco, le impulsa por la vida

("A un poeta muerto", vv. 71-72; ne Las nubes,

Cernuda, 1974, pág. 210).

Infine, in Historial de un libro, l'irrompere inatteso e fulmineo del momento epifanico, indipendente dal volere del poeta, è presentato in questi termini:

Desde que comencé a escribir versos me preocupaba a veces la intermitencia que ocurría, a pesar mío, en el impulso para escribirlos.. Este no dependía de mi voluntad, sino que se presentaba cuando quería; una experiencia inaplacable, una necesidad expresiva, eran, por lo general, su punto de arranque. (Cernuda, 1975, pág. 912) 
L'estasi scuote violentemente l'artista, posseduto da un divinus furor che "llegaba, en ocasiones, a sacudirme con un escalofrío y hasta a provocar lágrimas" (ibíd., págs. 912-913). L'approfondimento di questa idea fu molto probabilmente frutto dell'incontro letterario con i romantici anglosassoni, dove essa si trova esposta con chiarezza nelle prose critiche e nella produzione lirica.

In una lettera a Thomas Butts del 25 aprile 1803, a proposito della composizione del Milton, Blake rammenta: "I have written this Poem from immediate Dictation, twelve or sometimes twenty or thirty lines at a time, without Premeditation \& even against my Will" (Blake, 1966, pág. 823).

Di minore intensità, forse, ma di pari pregnanza, sono le parole adoperate da Wordsworth per descrivere l'istante dell'illuminazione, guidata da uno spirito proveniente da luoghi nascosti e ignoti, che visita il suo cuore a intermittenze (questo concetto assume un peso inferiore in Cernuda, a cui preme evidenziare innanzitutto l'incontrollabilità dell'epifania):

Nor is it I who play the part,

But a shy spirit in my heart,

That comes and goes -will sometimes leap

From hiding-places ten years deep;

("The Waggoner", vv. 209-212; in Wordsworth, 1904, pág. 144).

Nel saggio "On Poesy or Art", Coleridge mette in evidenza una forte carica inconscia nel processo di invenzione letteraria, poiché essa si fonda sugli stessi principi che regolano la crescita organica nei vegetali: "there is in genius itself an unconscious activity" (Biographia Literaria; in Coleridge, 1907, II, pág. 258).

Il paradigma romantico dell'iniziazione apoteosica del poeta-demiurgo, al di là della copresenza di elementi magico-rituali (il cerchio, il numero tre, il sintagma "holy dread", manifestazione del / timore reverenziale /, l'esplicito lessema "Paradise"), ritorna nei magistrali versi conclusivi di "Kubla Khan":

His flashing eyes, his floating hair!

Weave a circle round him thrice,

And close your eyes with holy dread,

For he on honey-dew hath fed,

And drunk the milk of Paradise.

(vv. 50-54; in Coleridge, 1985, págs. 103-104)

Anche a detta di Shelley, la creazione poetica è governata da una potenza imperscrutabile —interna all'artista-, che lo influenza talmente da annullarne la volontà individuale. I suoi tratti principali sono — come già abbiamo visto in Cernuda- l'imprevedibilità e la folgorazione, oltre all'arbitrarietà: 
A man cannot say, "I will compose poetry". The greatest poet even cannot say it: for the mind in creation is as a fading coal, which some invisible influence, like an inconstant wind, awakens to transitory brightness: this power arises from within [...] and the conscious portions of our natures are unprophetic either of its approach or its departure. (Defence of Poetry; in Shelley, 1909, pág. 153)

L'intervento di un potere sconosciuto e indecifrabile - che Cernuda frequentemente pone in relazione al "poder daimónico"- è alla base della composizione poetica pure nel macrotesto keatsiano:
And many a verse from so strange influence
That we must ever wonder how, and whence
It came. [...]
("Sleep and Poetry", vv. 69-71; in Keats, 1973, pág. 84).

Nei versi finali del Book III dell'Hyperion, infine, nella deificazione di Apollo, Keats simboleggia lo sconvolgimento della mente dell'artista per effetto della frenesia creativa:

Soon wild commotions shook him, and made flush

All the immortal fairness of his limbs -

Most like the struggle at the gate of death;

(vv. 124-126; in Keats, 1973, pág. 306).

Quest'ultimo confronto può ben costituire la chiusa della nostra analisi: per tratteggiare, infatti, il "poder daimónico", perno concettuale della sua poetica, Cernuda seppe operare una sintesi produttiva e originale delle caratteristiche attribuite all'ispirazione da tutti i poeti romantici inglesi a lui più affini. Non mancano certo altre "variazioni sul tema" dell'immaginazione, della poesia e del poeta, atte a enfatizzare ulteriormente le analogie ideologiche tra Cernuda e i romantici anglosassoni e, più ancora, forse, la dipendenza da questi del poeta sivigliano. Si è, tuttavia, ritenuto sufficiente circoscrivere l'esemplificazione ai casi testuali analizzati, perché particolarmente indicativi di una comunanza estetica corroborata da una diuturna e partecipe frequentazione letteraria.

\section{BIBLIOGRAFÍA}

BELLVER, Catherine. 1983. "Luis Cernuda and T. S. Eliot: A Kinship of Message and Motifs", Revista de Estudios Hispánicos, 17, págs. 107-124.

BLAKE, William. 1966. Complete Writings, edited by Geoffrey KEYNES, London, Oxford University Press.

BOWRA, Sir Cecil Maurice. 1961. The Romantic Imagination, Oxford-London, Oxford University Press. 
CERnUdA, Luis. 1974. Poesía Completa, ed. a cargo de Derek HARRIS y Luis MARISTANY, Barcelona, Seix Barral, $2^{2}$ ed., 1977.

-. 1975. Prosa Completa, ed. a cargo de Derek HARRIS y Luis MARISTANY, Barcelona, Seix Barral.

COLEMAN, John Alexander. 1969. Other Voices: A Study of the Late Poetry of Luis Cernuda, Chapel Hill, University of North Carolina Press.

COLERIDGE, Samuel Taylor. 1907. Coleridge's Biographia Literaria, edited by John SHAWCROSS, London, Oxford University Press, I-II.

—. 1985. The Oxford Authors: Samuel Taylor Coleridge, edited by H. J. JACKSON, Oxford, Oxford University Press.

COUSO CADAHYA, José Luis. 1976. "Búsqueda de lo absoluto en la poesía de Luis Cernuda", Cuadernos Hispanoamericanos, 316, págs. 21-44.

DIETZ, Bernd. 1979. "Luis Cernuda, traductor de poesía inglesa y alemana", Cuadernos Hispanoamericanos, 350, págs. 283-299.

HARRIS, Derek. 1973. Luis Cernuda: A Study of the Poetry, London, Tamesis Books.

HUGHES, Brian. 1988. Luis Cernuda and the Modern English Poets. A Study of the Influence of Browning, Yeats and Eliot on his Poetry, Universidad de Alicante.

KEATS, John. 1958. The Letters:1814-1821, edited by Hyder Edward ROLLINS, Cambridge (Mass.), Harvard University Press, I-II.

-. 1973. The Complete Poems, edited by John BARNARD, Harmondsworth, Penguin Books.

MARTÍNEZ NADAL, Rafael. 1983. Españoles en la Gran Bretaña: Luis Cernuda - El hombre y sus temas, Madrid, Hiperión.

ORTIZ, Fernando. 1985. "T. S. Eliot en Cernuda", Cuadernos Hispanoamericanos, 416 , págs. 95-104.

OTERO, Carlos Peregrín. 1963. "Poeta de Europa", Papeles de Son Armadans, XXIX, págs. 36-49; ripubblicato in Letras I, London, Tamesis Books, 1966, págs. 176-183, e in Letras I, $2^{a}$ ed., Barcelona, Seix Barral, 1972, págs. 259-269.

-. 1982. "Cernuda y los románticos ingleses" in AAVV, Studies in Honor of José Rubia Barcia (a cura di Robert JOHNSON e Paul SMITH), Lincoln, University of Nebraska Press, págs. 125-140.

PAZ, Octavio. 1964. "La palabra edificante", Papeles de Son Armadans, XXXV, págs. 41-82; ora in Cuadrivio, México, Editorial Joaquín Mortiz, 1965, págs. 165-202.

SEGRE, Cesare. 1984. Teatro e romanzo. Due tipi di comunicazione letteraria, Torino, Einaudi.

SHELLEY, Percy Bysshe. 1909. Shelley's Literary and Philosophical Criticism, edited by John SHAWCROSS, London, Henry Frowde.

SILVER, Philip. 1989. De la mano de Cernuda: Invitación a la poesia, Madrid, Fundación Juan March / Cátedra.

SUÁREZ-GALBÁN GUERRA, Eugenio. 1985. "Sobre la biblioteca privada de Luis Cernuda en Mount Holyoke”, Insula, 468, pág. 13. 
TALENS, Jenaro. 1975. El espacio y las máscaras. Introducción a la lectura de Cernuda, Barcelona, Anagrama.

VALENDER, James. 1979. "Cartas de Luis Cernuda a Edward Sarmiento", Cuadernos Hispanoamericanos, 347, págs. 308-318.

WORDSWORTH, William. 1904. Poetical Works, edited by Thomas HUTCHINSON, London, Oxford University Press. 


\title{
EL MODERNISME, HEREDERO DE LA ESTÉTICA ROMÁNTICA A propósito de dos cartas de Santiago Rusiñol a Víctor Balaguer
}

\author{
Antonio MARCO GARCÍA \\ Universidad de Barcelona
}

Como la mitológica Fénix al renacer de sus propias cenizas sin perder sus atributos, a lo largo de la Historia del pensamiento, las corrientes estéticas han ido surgiendo y re-apareciendo bajo diferentes terminologías - simples y perecederas calificaciones - pero con la conservación inherente de unas cualidades constantes, y eternas.

En Literatura aún se conservan intactas a su estudio e investigación unas "zonas" en las que se hallan múltiples informaciones, detalles, datos y conocimientos cuya importancia radica en que desvelan y aclaran muchos interrogantes que en la mayoría de las veces no han sido planteados. Al rescatar de la memoria "intrahistórica" algunos de estos documentos, se abren unas puertas por las que traspasa una luz que disipa dudas y confirma teorías en el campo del conocimiento y la erudición. Frente a los Manuales, a las historias y a estudios generalizadores en los que resulta más fácil aceptar una variante de lo conocido que alguna novedad, los Discursos, Prólogos, Palabras preliminares, o cartas ofrecen la praxis de valores, hechos y opiniones que, hipotéticamente, habían sido señalados. Transformar las afirmaciones en realidades, reinstaurar los valores de lo literario, y elaborar la substantividad estética son, en definitiva, los acicates que motivan el estudio de una de estas "zonas ocultas o intactas" del campo literario.

Las cartas, con una larga tradición en nuestra cultura española y a la vez tan del gusto decimonónico son un atractivo ejemplo. Siempre resulta curioso y sorprendente el hallazgo de documentos que durante años han estado ignorados por tantos estudiosos, como son las cartas; sus contenidos reflejan la verdad sobre la relación entre las dos personas implicadas, ofrecen múltiples perspectivas, profundas opiniones y criterios propios sobre temas y cuestiones diversas. Los 
documentos de este caso concreto se ensalzan unos a otros: las dos cartas manuscritas que Santiago Rusiñol escribió a Víctor Balaguer remiten, en sentido cronológico inverso, a un artículo que el político y novelista romántico publicó sobre el discurso pronunciado por el artista bohemio y literato en la Tercera Festa Modernista celebrada en Sitges.

El hilo de Ariadna, siguiendo las referencias mitológicas, permite descubrir unas muestras, manuscritas unas, otra recuperada de las páginas de una revista, y la última siempre mencionada, en las que se hacen patentes los ecos estéticos que, palingenésicamente, subyacen en el tiempo pretérito. Ante el desconocimiento de documentos resulta poco posible verificar tantas teorías y opiniones como se formulan; en cambio al recuperar algunos de estos escritos personales, como son las cartas, posibilita la demostración de algunas afirmaciones o hipótesis, o la modificación de otras.

La concatenación de las dos cartas manuscritas, el artículo publicado y el discurso prueban la relación entre estas dos figuras históricas que tuvieron una importancia decisiva en el mundo cultural de finales del siglo XIX. Entre Víctor Balaguer y Santiago Rusiñol, a pesar de las diferencias literarias e ideológicas, se reinstaura la unicidad de la concepción estética modernista heredada del Romanticismo.

\section{Estética literaria del Modernisme}

"Mientras la mayor parte de nuestras capitales de provincias mandan a Madrid casi toda la fuerza intelectual y artística de su genio, [...] Barcelona, que no parece España, florece en letras". (Alas, "Clarín", 1892, pág. 127). Durante las dos últimas décadas del pasado siglo, y en el período de entresiglos, se desarrolló una revolcuión cultural en la capital catalana que se manifestaba en un proceso de cambios en todos los niveles. Su materialización supuso la génesis de un movimiento estético que, consciente de la crisis de su época finisecular, quiebra el ritmo gradual de la Historia y anuncia una transformación radical: el Modernisme.

Juan Ramón Jiménez (1962) concibió el Modernismo, movimiento paralelo al que se daba en Cataluña, como una época histórica análoga al Romanticismo o al Barroco; en la misma línea su discípulo Ricardo Gullón (1980, pág. 12) puntualizó:

reiteraré con cierto énfasis algo que nunca debiera olvidarse: el modernismo es prolongación del romanticismo, pero prolongación muy peculiar.

En su amplio significado, el término "modernista" no sólo designa una escuela artística, sino una posición ideológica, o mejor una actitud vital, ya que 
"prácticament la mateixa concepció d'escola literaria entra en crisi des del Romanticisme" (Marfany, 1975, pág. 55). Fueron los propios modernistas los que, primeramente y de forma más o menos sistemática, se autodesignaban con este calificativo al considerarse diferentes respecto a los otros en un mundo cultural; por encima de inclinaciones estéticas y preferencias ideológicas concretas, y con un propósito fundamental en el que radicaba toda su razón de ser, se propusieron renovar la cultura y las concepciones derivadas de ésta en un ambiente de confusión y pesimismo que suscitó, a su vez, la caída del positivismo filosófico y del naturalismo literario. Eduard Valentí (1973, pág. 20) opinaba al respecto:

Hemos de concebir el modernismo, no como una concreta doctrina o escuela estética, sino como una cierta actitud que se adopta en una situación determinada, casi como una solución que se arbitra o se propugna para salir de un estado que se quiere corregir.

Respecto al resto de España, el concepto de "modernismo" reviste unas formas peculiares y exclusivas en Cataluña al depender directamente de las especiales condiciones económicas, sociales, políticas y culturales. La cultura catalana, al atribuírsele una sustantividad propia, puede ser definida en relación a su proximidad geográfica con Europa, ya que su mirada, por aversión, demasiadas veces, a otras direcciones, se dirigía hacia los movimientos intelectuales y de pensamiento que surgían en los países europeos, y en concreto a su mundo literario. También es cierto que la cultura catalana demostró una sensibilidad más a tono con el espíritu ultra pirenaico que a los cambios peninsulares; en las demás culturas hispánicas la influencia podía ser sincrónica o posterior en relación con Cataluña. Esto lo apreció Rubén Darío (1897, pág. 266) tras su estancia en España:

Los "menos" de la joven escuela catalana, como los escritores, están al tanto de lo que en el mundo entero se produce, de las evoluciones del arte universal contemporáneo, y siguen lo que se debe seguir del pensamiento extranjero.

Si bien como apunta Joaquim Marco (1983, pág. 19): "Al seu origen, el Modernisme a Catalunya sorgeix com a reacció contra el naturalisme", al ser un movimiento reactivo, implícitamente comportaba una ruptura, que no negación, en su esencia respecto a todo el pasado reciente:

Quan els modernistes arremeten contra la generació precedent, ho fan en funció del pensament conservador que havia frenat l'apropament del intel.lectual a l' heterodoxia' europea (per utilitzar una expressió que tan grata va ser a Menéndez Pelayo). (Marco, 1983, pág. 21).

El Naturalismo era la reacción antirromántica al propugnar una literatura 
basada en la expresión científica, documental y objetiva de la naturaleza y de los hechos psicológicos. Si bien el primer supuesto naturalista fue el positivismo de Auguste Comte llevado al campo de la biología por Claude Bernard, su definidor en el mundo literario y máximo representante fue Émile Zola, quien asimiló las ideas de Bernard sobre la experimentación fisiológica y las teorías estéticas de Hyppolite Taine, y se erigió como el principal teorizador de una "escuela literaria de base científica" entre cuyos miembros destacaban los hermanos Goncourt, Guy de Maupassant, Daudet, Céard, entre otros. Pese a los continuos reproches de la crítica de la época, lectores e intelectuales de diversa formación cultural aceptaron el Naturalismo, y alcanzó su cenit hacia 1890.

En España el Naturalismo penetró muy escasamente, en formas atenuadas y derivadas que aludían o mitigaban las connotaciones ideológicas, la irreligiosidad y el determinismo, características propias de los naturalistas fracnese. Emilia Pardo Bazán publicó una serie de artículos que, bajo el título de La cuestión palpitante, hizo apología y estudio de un naturalismo muy sui generis, y cuyas repercusiones fueron más polémicas que prácticas. En Cataluña se desarrolló un naturalismo entre 1880 y 1900 que se caracterizaba por extremar los aspectos obscenos y el lenguaje vulgar y de jerga que la esencialidad del movimiento, el determinismo. Santiago Rusiñol que "no és el capdavanter del moviment modernista, sinó d'un dels moviments més modernistes" (Marfany, 1975, pág. 37) define pictóricamente el sueño modernista y la pesadilla naturalista en los respectivos ensayos titulados significativamente "Un somni rosa" y "Un somni negre":

Per pintar-lo, tot passant, amb les plomes de les ales daven una pinzellada i hi deixaven un color; tornaven, i hi posaven una aroma; $i$, al ser la corol.la plena, aquel quadro sense fondo ni figures fou un fondo de harmonia que s'hi deleitava l'anima. "Modernisme" [...] Era un quadro d'una veritat espantosa: una dona despullada, grassa i malalta, groga i fornida, que no podia mirar-se. Com un cadell de dragó barrejat de gossa, va llepar-li el pit i la cara, va firmar "Naturalisme" i va tornar-se'n a la caixa. (Rusiñol, 1976, págs. 121-122).

Y en su conversación "Modernisme" intenta definir la teoría de este movimiento estético:

Es com una dona hermosa, que s'admira de sa hermosura, sens poguer-la definir; és como aire embalsamat, que el cor l'olora i el cervell no se l'explica. Es més amor que coneixença. (ibíd., pág. 613).

Aunque el pintor y literato catalán reconocía en una carta dirigida a Gaietà Soler que:

El Modernisme no va enlloch determinat, sinó que representa l'aspiració vaga dels qui, desenganyats del Naturalisme, que havia de ser lo regenerador 
de l'Art y de les Lletres (como lo Racionalisme ho havia de ser de les Ciències filosófiques) y mancats de fe per a entendre i abraçar l'Estètica catòlica, cerquen quelcom de nou que ampli i satisfassi sos esperits creats per a comprendre la Veritat i sentir la Bellesa”. (Planes, 1969, pág. 17)

Hartos y "des-engañados" de los abusos y extremosidades del Naturalismo y de sus preceptos estéticos, los modernistas propugnaron la creación de obras, artísticas o literarias, de las que posteriormente se pudiera extraer una estética, y no de forma inversa partir de unos principios previos, a priori, para configurar una creación.

En contínua "quête" de ideales, ilusiones, hermosuras y sueños, la estética modernista literaria catalana se polarizó, en una primera etapa (1892-1900), en dos vertientes: uno regido por la tendencia voluntarista o regeneracionista, caracterizado por la exaltación del individualismo nietzscheano unido, a su vez, al concepto de "artista comprometido con la sociedad"; y otro, de aspiraciones esteticistas que, de clara influencia simbolista, inició un auténtico culto a "l'art por l'art" y la Belleza. Ambos caminos no se oponen entre ellos ni son, en su quintaesencia, incompatibles, y sí pueden equilibrarse sustancialmente $o$ predominar solapadamente una sobre otra en un artista o en alguna obra concreta dentro de su producción creativa. Todo ello lo encarna y asume la figura de Santiago Rusiñol, cuya posición, según lo apunta Eduard Valentí (1973, pág. 303):

dentro del modernismo ofrece características tales, que ha podido ser considerado por unos como creador, introductor y jefe del modernismo, una especie de partido que tenía su cuartel general en el Cau Ferrat, mientras otros lo consideran como una figura marginal y secundaria dentro del mivimiento.

Pero indudablemente su actitud conservó la concepción individualista y rebelde de artista, y la tendencia esteticista y simbolista, al otorgar predominio a la experiencia estética y a la intimidad efectiva para lograr la expresión del pensamiento, y así, rehusar cualquier objetividad o representación externa. Postuló una actitud bohemia que, característica del Modernisme, "deriva del Romanticismo" (Marco, 1983, pág. 36), aunque genéticamente fuera una respuesta de inadaptación social, de protesta personal contra el capitalismo y la clase burguesa a la que, curiosamente, el propio Rusiñol pertenecía; es lo que se ha denominado la "bohemia dorada". El Modernisme producía, por primera vez, una generación de intelectuales y artistas rebeldes a su propia clase social de la que no renunciaban; el artista, insistente en la exaltación nietzschana de la voluntad y del mesianismo, se atribuía el papel de guía y profeta con una actitud independiente y libre, o mejor individualista. En realidad, "pràcticament fins l'avanguarda, el triomf de l'individualisme serà absolut" (Marco, 1983, 
pág. 55); el artista adopta una postura "impregnada claramente de anarquismo literario pour épater le bourgeois (Aznar Soler, 1980, pág. 79).

Entre estas tendencias la personalidad compleja y profunda de Santiago Rusiñol convive sincréticamente, y se evidencia en su vida y en sus obras; una reacción espiritualista, muy cercana al Romanticismo, exalta el idealismo, se hace eco en la estética del artista bohemio, quien en el ensayo titulado "La oración del domingo" expone este sentimiento espiritual-religioso en términos artísticos basado en una metáfora teológica para expresar un concepto creativo:

Ser devoto de algo, en estos tiempos en que la duda y la irreligión invaden los corazones y el malestar se cierne en todas partes como epidemia del alma, ese don precioso que hay que conservar como el mayor tesoro (Rusiñol, 1976, pág. 723).

El poeta y ensayista catalán Joan Maragall, heredero del espíritu del Romanticismo y del sentir poético de Jacint Verdaguer, veía en este intento espiritualista un renacimiento de la pasión romántica que se habría mantenido en latente represión bajo el naturalismo, y que ahora reaparecía bajo el nombre de "Modernisme"; él lo calificaba de "neo-romanticisme" ya que el Naturalismo, según Maragall, no poseía connotaciones nocivas ya que gracias a su experimentación el Romanticismo había logrado penetrar en la realidad:

la contrarreacción no podía menos de venir, y ha venido; el romanticismo ha proseguido su carrera después de haberse saludablemente penetrado de realidad en el naturalismo poético y de haberse estremecido con vagos presentimientos del alma (Maragall, 1931, pág. 151)

\section{Santiago Rusiñol, el "Cau Ferrat" y las "Festes Modernistes" en Sitges}

La dualidad del arte como rebelión y ruptura, y su concepción estética como pasión, se convertirá en característica esencial del movimiento modernista y, particularmente, del "incansable propagandista y consumado maestro del modernismo" (Pardo Bazán, 1895) que era Rusiñol, que fue definido, también con acierto y precisión por el vate del Modernismo hispano-americano, vislumbrando la doble complementariedad señalada:

Bellamente, noblemente, a la cabeza de la juventud, Rusiñol, que no escribe sino en catalán pone en Cataluña una corriente de arte puro, de generosos ideales de virtud y excelencias trascendentales $[\ldots]$ por él los nuevos aprenden en ejemplo vivo que el ser artista no está en mimar una bohemia de cabellos largos y ropas descuidadas y consumir "bocks" de cerveza y litros de ajenjo en los cafés y "cabarets", sino en practicar la religión de la Belleza y de la Verdad, creer, cristalizar la aspiración en la obra, dominar el mundo profano, demostrar con la producción propia la fe en un ideal, huir de los apoyos de la crítica oficial, tanto como de las 
camaraderías inconscientes, y juntar, en fin, la chispa divina a la nobleza humana del carácter (Darío, 1987, pág. 39).

La figura de Santiago Rusiñol, como dramaturgo, teórico y artista modernista, asume los rasgos más significativos y trascendentes por su caracterización de "leader" en la iniciativa estética moderna, y por ser el organizador infatigable de las "Festes Modernistes del Cau Ferrat" en Sitges; no debe olvidarse su importante labor desarrollada en Barcelona con un significativo grupo de artistas que frecuentaban el local de "Els Quatre Gats".

Como guía artístico de un movimiento estético, Santiago Rusiñol proporcionó los fundamentos teóricos, y los llevó a la práctica en dramas, comedias, pinturas, etc., a pesar de que sus relaciones con el Modernisme parecieran, en determinados momentos, un tanto ambiguas. Aunque la mayor manifestación pública y colectiva de esta "moderna estética" estuvo organizada por Rusiñol: a partir de 1892 se celebraron unas fiestas en Sitges, localidad próxima a Barcelona, que

abans l'aparició de Rusiñol a Sitges, aquesta villa era un recó perdut en la seva propia calma, gris d'esperit sota el resplandor del nostre cel. Rusiñol donà a Sitges el tó de la seva ànima i des d'aleshores Sitges és conegut com una joia exquisida i rara (Catasús, 1933).

Sitges, y más particularmente el "Cau Ferrat" se convirtieron rápidamente en la "Meca del Modernisme"; empezaron a ser motivo de comentarios diversos en todos los periódicos y revistas, tanto de Sitges como de la comarca, de Barcelona, Cataluña y de toda España, y tema constante de conversación porque desde el "Cau" surgían cuestiones polémicas o insignes visitantes eran huéspedes de Rusiñol. Así el eco de los acontecimientos se reflejaba en la prensa local con una asiduidad asombrosa:

¿De dónde ha nacido ese notorio movimiento artístico y literario por el cual nuestra villa ha adquirido popularidad hasta el punto de ser considerada como un nuevo centro de cultura intelectual? Es innegable que se debe a esa tan discutida y combatida escuela que el gusto moderno ha sabido saborear y que tantos prosélitos ha hecho en esta villa (La Voz de Sitges, 1896).

Mientras Santiago Rusiñol está en Sitges, esta localidad no pierde su característica de ser la avanzadilla de las artes y de la literatura. En ella se celebran las "Festes Modernistes" entre 1892 y 1898 coincidiendo con la que ha sido considerada "etapa de plenitud" de Rusiñol que se inicia en 1889 , su primera estancia en París, y finaliza en 1895, año decisivo en el transcurrir de la concepción modernista ya que a partir de esta fechas las manifestaciones y sesiones modernistas serán menos asiduas, a la vez que disminuyen las estan- 
cias de Santiago Rusiñol en Sitges; en 1895 Rusiñol va a Granada y, posteriormente acompañado por Joan Maragall, va a Montserrat por cuestión de su enfermedad.

Entre las personalidades que visitaron el "Cau Ferrat" destaca la de Emilia Pardo Bazán quien, tras su estancia, opinaría:

Estoy perfectamente convencida de que todo ha sido un sueño, y de que no hay en el mundo tal "Cau Ferrat" ni tales patios azules y colorados, ni nada de eso que ahí creí ver como Sancho cuando ascendía sobre el lomo de Clavileño. Al que sostenga que todo eso existe le desmiento. Porque en verdad aseguro a Usted que el único defecto del "Cau Ferrat" sería existir. Lo que existe con la grosera existencia llamada real sufre los accidentes del cambio y de la destrucción. Sólo lo que no existe no muere nunca. (Pardo Bazán, 1895, pág. 2)

$Y$, también, Rubén Darío que manifestó su deseo de visitar el "cau" de Rusiñol:

Cuando vuelva a Barcelona he de ver a Santiago Rusiñol en su retiro de Sitges, una especie de santuario de arte en donde vive ese gentilhombre intelectual digno de ser notado en el mundo. Entretanto, sabed que Rusiñol es un altísimo espíritu, pintor, escritor, escultor, cuya vida ideológica es de lo más interesante y hermosa, y cuya existencia personal es en extremo simpática y digna de estudio (Darío, 1987, pág. 39)

Hasta 1893, fecha de la celebración de la "Segona Festa Modernista", el término "Modernisme" no designaba una estética concreta, una "escuela artística", sino una posición ideológica y, más aún, una actitud. Es en 1894 cuando "el certàmen del Cau Ferrat [...] tingué un tó esteticista molt marcat [...] I per aquest camí "modernisme" arribà aviat a confondres amb -per entendre'ns"esteticisme simbolista-pre-rafaelista-decadent" (Marfany, 1975, pág. 46). Desde 1893 hasta 1898 la influencia de la estética simbolista, básicamente francesa (Verlaine, Rimbaud, Baudelaire, Mallarmé), domina en el Modernisme, y en las concepciones de intelectuales y artistas, como Rusiñol. El Simbolismo evitó todo propósito retórico y didáctico y tendió más a evocar estados de ánimo, y a la sugerencia en lugar de nombrar; así conseguía su finalidad idealista propuesta.

El Modernisme era, explícitamente, decadentista y simbolista; pero, implícitamente, también era regeneracionista y vitalista al modo nietzschano: esta doble concepción del arte aparece en textos programáticos de la revista L'Avenç, y también en los manifiestos de Santiago Rusiñol. 


\section{"Discurso de la Tercera Festa Modernista" de Santiago Rusiñol, "Sitges la Blanca" de Víctor Balaguer, y dos cartas de Rusiñol a Balaguer.}

El día 4 de noviembre de 1894 se celebró la "Tercera Festa Modernista", una de las más memorables y renombradas manifestaciones públicas del Modernisme, en ella participaron escritores y artistas de muy variadas tendencias y concepciones estéticas; en esta diversidad radicaba la búsqueda de lo nuevo y el intento de unificar impulsos estéticos de diversas artes, propósito éste tan modernista como romántico. Ramon Planes (1969, pág. 86) enumera los asistentes a tan importante reunión:

Es concentrà a la vila blanca la plana major del modernisme. El primer d'arribar, procedent de Tarragona, fou el crític Josep Yxart. "El partit abans que tot!" havia escrit aquell home, malalt greu, en una carta a Rossinyol en la que li prometia l'assistència a la festa. Després en el tren de Barcelona, arribaren: Narcís Oller, Pin i Soler, Joan Maragall, Albert Llanas, Frederic Rahola, Pompeu Gener, Ramon Casellas, J.M. Jordà, Sánchez-Ortiz, Albert Rossinyol, J. L. Pellicer, Josep Labarta, Ramon Casas, Eliseu Meifrèn, Soler i Rovirosa, Enric Clarassó, Joaquim Cabot, Francesc Rogent, Puig i Cadalfach, Maspons i Labrós, Josep Pijoan, Massó i Torrents, Josep Aladern, Manuel Rocamora, Garriga i Massó, Casa-Carbó, Joan Sardà, Josep Pascó i J. Soler i Miquel, entre altres.

Si bien la fiesta decepcionó y desengañó a los organizadores, como Yxart le cuenta por carta a su primo Oller:

No sé què vàren pensar del certàmen, però amb en Rusiñol vam convenir que havia estat un vertader "fiasco", donada la transcendència que nostre amic li volia donar...jun vertader fiasco...dolent, dolent, dolent! [...] va resultar una desgràcia aquella tentativa "modernista". Desenganyem-nos a les nostres velleses no ho és, no ho és, el nostre, un pais artista! (Yxart, 1936, pág. 47).

Desde la celebración de la "Tercera Festa", el "Cau Ferrat" se erigió en lugar de referencia para todo aquel que se sintiera "modernista" o simplemente simpatizara con las ideas del movimiento estético que Santiago Rusiñol expuso en el discurso que pronunció en este acontecimiento con el propósito intencional de:

prendre aiguies de poesia, malalts que estem del mal de la prosa que avui corre en la nostra terra *

Entre las visitas que se recibieron en el "Cau Ferrat" sobresalen las no pocas de Víctor Balaguer que realizó con la grata compañía de amigos y conocidos, ya fuera por ser Académico de la Lengua o en calidad de afiliado al Partido Liberal o por su condición de ser uno de los restauradores de los Jocs

* Citaré como "Discurso, p." el pronunciado por Rusiñol en la "Tercera Festa Modernista", publicado en sus Obres Completes, Selecta, Barcelona, 1976, vol. III, pag. 609. 
Florals y propulsor de la Renaixença catalana. Santiago Rusiñol quiso que el "Cau":

sigui sempre, el nostre Cau, un "cau d'illusions i d'esperances"; que sigui un refugi per abrigar an els que sentin fred el cor; un pedrís on reposar l'esperit que arriba malalt del camí enfangat de la terra; una ermita prop del mar, hospital dels ferits d'indiferència, i posada de pelegrins de la Santa Poesia, que vinguin a veure espai, a respirar núvols i mar i tempestats i serenes, [...] i continuar la Santa Lluita. (Discurso, pág. 611).

Y Víctor Balaguer, primer poeta proclamado "Mestre en Gay Saber", dijo del mismo lugar:

¡El Cau Ferrat! Hay que hablar, hay que hablar de esta humorada, que ha tomado todos los aires y todos los vuelos de una institución. El Cau Ferrat es un capricho que ha venido a erigirse hoy en el templo suntuoso del modernismo [...] Los entusiastas de Rusiñol, los impresionistas, los modernistas, los decadentistas, los que en Cataluña obedecen a esa especie de movimiento febril que se ha apoderado de cierta juventud sin atender a que todo consiste en dar forma nueva a una idea antigua, consideran el "Cau Ferrat" como el santuario del Modernismo, y a él acuden en procesión y romería. ${ }^{* *}$.

Santiago Rusiñol, halagado y agradecido por estas palabras, le ofreció a su autor, Víctor Balaguer que pasaba largas estancias en la vecina localidad de Vilanova i la Geltrú, su "Cau", en una carta del día 16 de diciembre de 1894 desde Ille St. Louis, París:

en Sitges me he construido mi estudio, que más que estudio es un modesto nido cerca del mar, para que quizás más tarde cuando esté cansado de correr mundo y de ver cuadros y más cuadros y escuelas y sistemas sucediéndose unas a otras con esa ingrata rapidez moderna, vaya a refugiarme en él para vivir con el sosiego que empiezo a desear. [...] Sé que V. ama el mar, sabemos todos que es V. poeta de los de "fondo" y si mi rincón puede servirle para el menor indicio de deseo de su alma, aunque yo no esté lo encontrará V. abierto ***.

Original es esta definición de movimiento modernista, y peculiar resulta la calificación de "poeta de fondo" al romántico e idealista Balaguer por parte de Rusiñol.

** Citaré como "Artículo" el titulado "Sitges la Blanca" que Víctor Balaguer publicó en la revista madrileña Pro Patria (segunda época), III, XXI (septiembre, 1985). Esta fechado en la "Casa Santa Teresa, en Villanueva y la Geltrú, Agosto de 1895". (Artículo, pags. 658 y 662).

*** Citaré como "Carta 1" esta carta de Santiago Rusiñol a Víctor Balaguer; no señalo el número de página ya que es manuscrita. 
El modernisme, heredero de la estética romántica

A.L.E.U.A. $/ 8$

$C|23| 0|g 4|$

94

Victor Galaques

Paris th al' live

Cleuy hr mis y distingus:

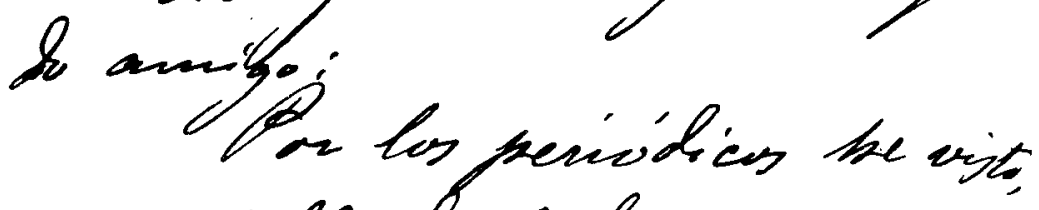
que sextablecido de la grave eufer.

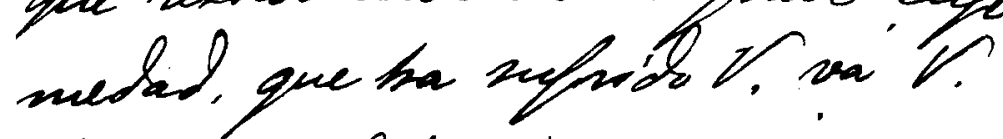
- conpletas in curacion, in Villamena geltri:

Asdlcomes senti grandemente moblencere, deseasia gre mu consalecenció fresa lo mas costa fars: ble, I deseasiá que za parak contimuara t. ew fillanerea liv de que el pripecins vesans puobiesa housasme tersiend old

Carta manuscrita de Santiago Rusiñol a Víctor Balaguer, que se halla en la Biblioteca-Museo Víctor Balaguer de Vilanova i la Geltrú; no está catalogada, pero su signatura es: ms.405 nº 94 (Diciembre 1894)

143 
A.L.E.U.A. $/ 8$

ANTONIO MARCO GARCIA

you veins.

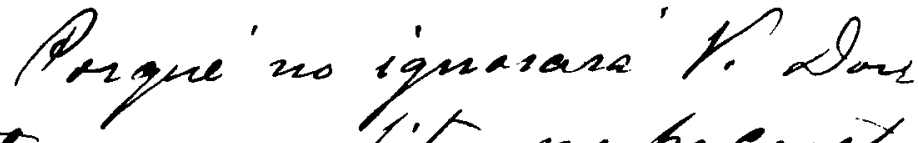
Victor que en Hitage me he curethy; do mi' extudio, que may que extudi. es un modesto nide cenca del mas para jue quizas mas tasede. cuands ente' ya camado de carres mundoy de ver cuadrog may cuadry g escuelay g nitemay ruce. Licidere unal otial con eja ingra. ta rapidey moderma, seaya a' refu. giarme en el jara vives con el so. siego que enpriezo a' desear.

Frte estrobis y of ohate de mi cartai es decin: ghrecezbels. - Con toda la frangueza cartalana. he que T. ama el mas, tabenny todos que is if pueta de los de fondo

144 
El modernisme, heredero de la estética romántica

A.L.E.U.A. $/ 8$

$y$ s'm sincon pruede zersizle pari el menos indicis de dexes de m alma, Bungue yo no este

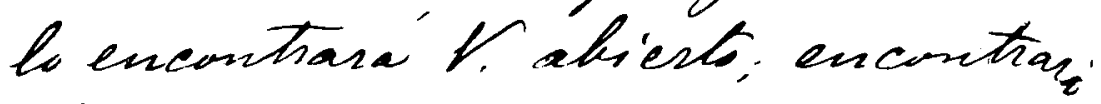
T. cama, encuntrasa' V. ofgetas que de reguns le dizoin algo a 'ne caszun. de astiplay noluetols encustran. T. de mi praste una buena solin. tas.

Asigues, zin cumptilos, dow lictas, all'esta' yu casa. y me

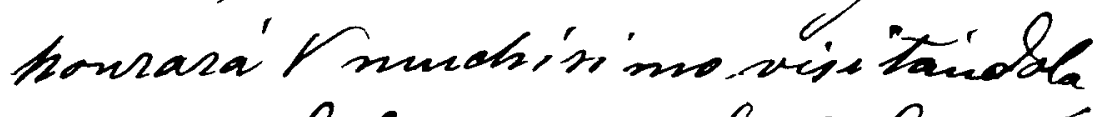
trabitaíbla y considenaidala come preprá

El anigo Slanas que beta'

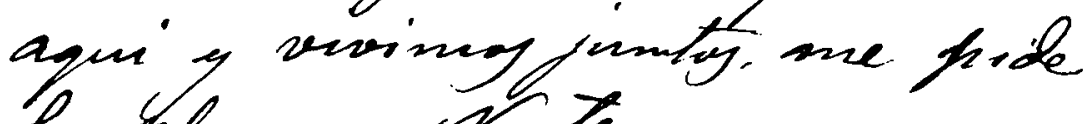
la Jlima. No teugo ma que

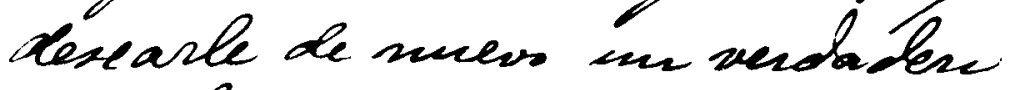
vextableimients. Lelosasmue

145 
A.L.E.U.A. $/ 8$

ANTONIO MARCO GARCÍA

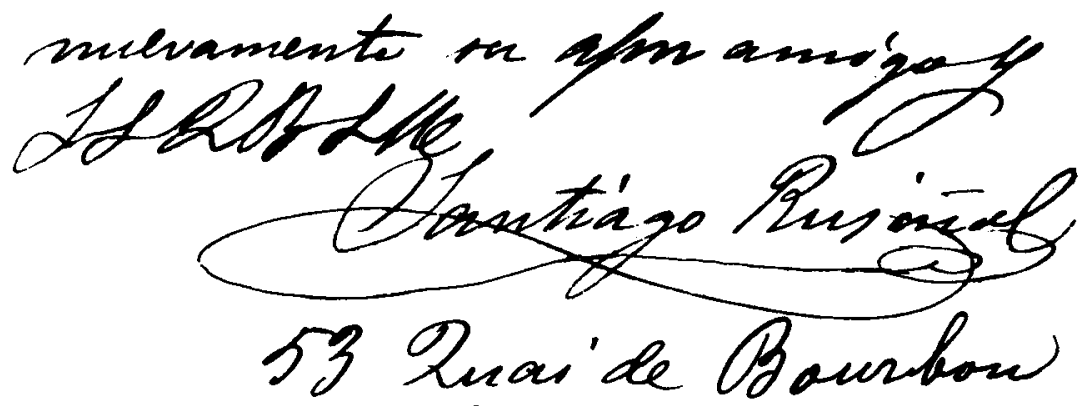
Ille th Loniy.
Panis.

Ferovara' la clawa la lande. Graciós per la wito.

146 
En el discurso leído en el "Cau Ferrat" Rusiñol enunciaba la doctrina basada en el concepto aristocratizante del "arte por el arte"; pero al presentarlo como un extremado alegato le comportó una oposición tajante, la del poeta Joan Maragall; de las relaciones de éste con el Modernismo se descubren las virtudes y las faltas de este movimiento por la aguda y penetrante visión del autor del Elogi de la Paraula y de Visions $i$ cants. Maragall reconoce que el Romanticismo se prolonga en el movimiento modernista que es calificado como "reacción neorromántica":

i si escolteu atentament, recollidament el terrer naturalista, hi sentireu passar per sota la gran corrent romàntica, que ha reaparegut entre nosaltres amb el nom de modernisme. (Maragall, 1930, pág. 89).

Reveladora resulta la reacción que el poeta, historiador y pionero del drama romántico, Víctor Balaguer, tuvo tras la lectura del discurso que Rusiñol pronunció en la "Tercera Festa Modernista". El que se autocalificó de "idealista" opina, en su mencionado artículo, que las dos corrientes estéticas que se encarnaban en sus figuras iban por "buen camino":

¿Qué nos separa, pues a los idealistas de los modernistas? Si así se define el dogma nuevo, si es esto el impresionismo, si esto es el modernismo, entonces todo marcha por el buen camino, todos podemos entendernos, todos somos unos..."et ego in Arcadia" (Artículo, pág. 663).

Según opinaba Rubén Darío (1987, pág. 39): "En este movimiento, como sucede en todas partes, los que han quedado atrás o callan, o apenas son oídos. Balaguer es ya del pasado, con su pesado fárrago"; pero el académico y promotor de la restauración dels Jocs Florals en 1859 creía en la resurrección estética de los ideales del Romanticismo en el Modernismo: la importancia concedida a la libertad artística, a la sensibilidad y a la emoción subjetiva del escritor como referencia a la afirmación del "yo"; el encumbramiento de la imaginación como fuente creativa e inspiradora de la obra literaria, y el considerar en un mismo plano de igualdad la razón y la facultad del espíritu; la admiración por la Edad Media, los países exóticos y la naturaleza selvática y bárbara, en las que el paisaje animado con atributos subjetivos cobra dimensiones desconocidas; la revitalización de la propia tradición, formando un espíritu nacionalista y propio; etc., etc. Tal es el propósito de Santiago Rusiñol que expone en el citado discurso:

Ella vindrà, aquesta aurora; ella vindrà algun dia, malgrat els núvols negres, i el goig de sentir-la que s'acosta, de pressentir que els artistes aquells $i$ aquells poetes, des de llur tomba inmortal i gloriosa, ne veuran d'altres com ells, ens fa viure esperançats, an els que creiem en una hermosa renaixença.(Discurso, pág. 611). 
En clara referencia a las figuras que, como Víctor Balaguer, pertenecian ya a un pasado histórico; desde éste, y a pesar de las opiniones, Balaguer manifiesta que:

Entonces esto quiere decir, o yo no sé leer, que en las esferas del arte y de la luz caben todos; que urge marchar en santa cruzada hacia las esferas donde reina el ideal, el ideal de la Belleza y de la Fe; que la inspiración debe ser el acicate de esa juventud que se agrupa al pie del estandarte comunero de los modernistas, el arte su luz, el genio su aliento, la fe su sostén y el ideal su esperanza y su fin. (Artículo, págs. 663-664).

Este artículo, lleno de énfasis y ampulosidad romántica, fue el pretexto para que Rusiñol contestara al autor, Balaguer, con una carta fechada el 18 de septiembre de 1895 desde Sitges; en ella Santiago Rusiñol le responde:

Una de las cosas que más me satisface, es el ver cuan fácilmente me ha entendido, con sólo leer mi discursito. V. casi se declara modernista y yo cuasi me declaro romántico y digo cuasi porque no me atrevo a quitárselo por lo de modernista, pero estoy convencidísimo, que en pocas sesiones que pudiéramos hablar, estaríamos perfectamente de acuerdo. ****.

En este "discursito" Rusiñol exponía claramente la idea estética que vertebraba todo el Modernisme; esta manifestación trascendió y se convirtió en un manifiesto lleno de exaltación y apasionamiento. De él dijo el escritor Josep Pla (1981, pág. 124): "en aquest discurs hi ha tot Rusiñol. Es un document autobiogràfic important. Hi ha també tot o gairebé tot el modernisme".

La aguda visión de Pla demuestra que el discurso de Santiago Rusiñol adquirió la característica de "Manifiesto". En él su autor no sólo define y caracteriza el movimiento modernista, sino que, además, se retrotrae a un pasado reciente, a los antecedentes del Modernisme, al Naturalismo como estética antagónica a la del movimiento modernista, y a la del Romanticismo:

D'aquell art fet avans, com plogut de rosada d'una aurora; [...] d'aquell art somniat miran enlaire i buscat en el pensament que veu visions d'un més enllà vaporós i difumit; [...] no en queden més que espurnes, dèbils avergonyiments, guspires mig apagades per l'alé fred d'un poble que se li diu positivista i que s'alaba d'ésser-ho. (Discurso, pág. 610).

El Naturalismo, como actitud filosófica en la que la naturaleza no tiene ninguna causa transcendental, que existe por sí misma, se inclinó hacia métodos de descripción científica e inventarios puramente objetivos de la realidad, con una descripción minuciosa y complaciéndose en los aspectos más ingratos

**** Citaré como "Carta 2" esta carta de Rusiñol a Balaguer; al ser documento manuscrito no señalo la paginación. 
El modernisme. heredero de la estética romántica

A.L.E.U.A. $/ 8$

et. I Victor Balagues.

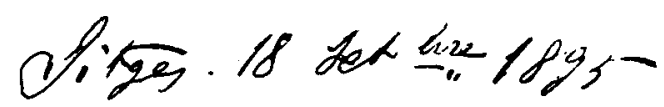

Hei dijtriquidricies asonge:

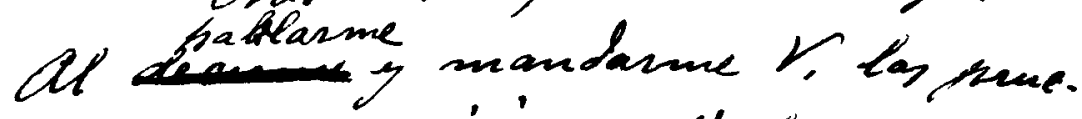

for de ne bersussisins astículs, parece

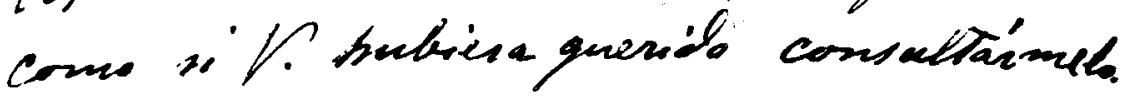
Aqui empiezon las primesas graciós que le byy, pero. ( zienzine hay um pero)

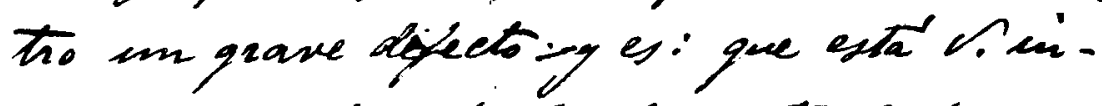
juste conneigo. hasta el punte de hacel. me pasnoyiar, hathands de su' solue feerzona, en terming taw eyagerads cono ber moramente. eppresady. probando una. vey masily arti zea diche en fise de lon paety. coms II que gusien tiene la cinaginacion. he Vipued racen pastido de lo mais senci: Ule y modesto.

fuento mas yageradas seameprey bes

Carta manuscrita de Santiago Rusiñol a Víctor Balaguer, conservada en la Biblioteca Museo Víctor Balaguer de Vilanova i la Geltrú, sin catalogar, aunque su signatura es: ms.408 n83 (1895 Septiembre).

149 
A.L.E.U.A. $/ 8$

ANTONIO MARCO GARCÍA

alabruzas, mas merecen que bas quecis

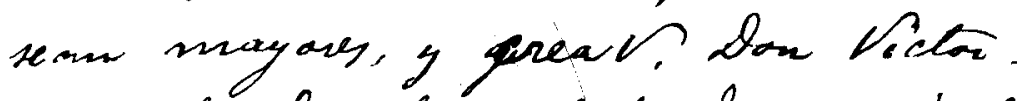
que se has oby deyde of fouds de mi alma, Is ast'culo que apradezes, no por la vintul de las letros de medde, pins fror quien bas ha kecho mover, en de. cis, que si el atticulo en wy de ser aetáclo fuers carta particular. equelmente quedaria igradecids.

Tura de la, cosas pue may me ra. triface, as ol wer cuan facilmente me ha entendido, con nlo leir mi discumito. U. cuasi ze declasa. moder nijta, "yo cuan' me declase. somantico y diǵ

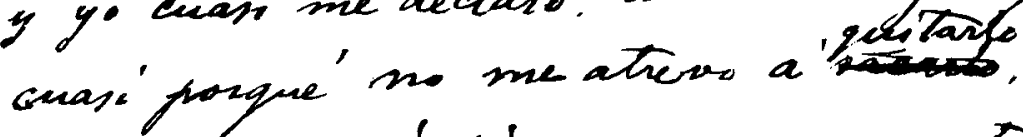
pou lo de somantaics. I mens me atre. vo a guatarsels yion lo ar moder. nitta, pers estay convencidisimes, gere en pocas zessivaly que puebiesarnos ha.. blas, extanioms penfectamente levacuesd.

150 
El modernisme, heredero de la estética romántica

A.L.E.U.A. $/ 8$

Wor une una/e'; el amm a'Pa, holici y al arte, y no une una astifistiá; el naturalioms cams bcuela. Ios naTuralijtay, cres que fueron las que quitienow demisias el Komantiéjmo, parsiéndale pos delaute un aste, que ze fue comvintiends, al epagorasse, en jotofrafia al tratasse de pintura, y en inventare: of tha. Tarse de tilteratura.

Les moder nistat, al puotos tar, seo yue les rengan $a$ ' $/ 3$. Los somantices ze dejason llevas guijas de la inag.'ma. cion, los modesnitas quezay de la cimpresiow, pere prefiess esto a ince escuela que quesio convertis of arte en ciencí y juizas trubiera terminads an trojicene.

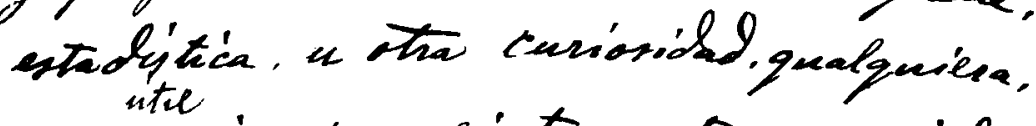
ming guigor prasa ciésta gente, peso cinds. ma para of aste, que siempre texdra'cl encauts, de lo rage, nebulore.

151 
A.L.E.U.A. $/ 8$

ANTONIO MARCO GARCÍA

Dero dyengy este yparte. Ya hable. zemon.

Heil geacias tha ug. las cualey espers daircelas de palabra a'fasimesos de Dctaklue que irengy a' Meadrid de paso pasa Andaberá. con el amojo Htriblo, que me encanga gue le salud. Hescho be estimare' que al zer problicad of articulo, mande alquen mai.

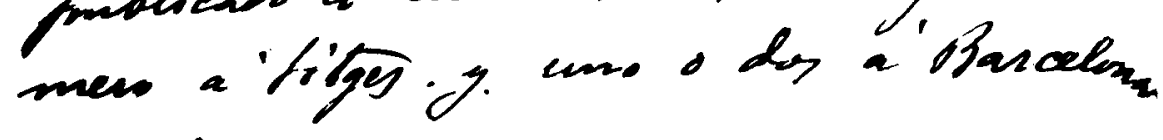
en on casa

Princera 37

Orn ming freste alingo, de mad. misals if tharta may provets se

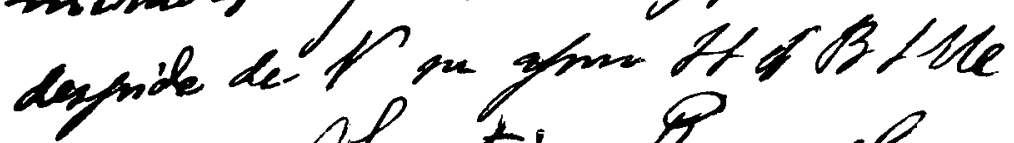
Aantiag. Burnere

152 
de la vida. La característica más definitoria del cuerpo de la doctrina naturalista es el materialismo en el que se integra el determinismo biológico, el evolucionismo de Darwin y las teorías hereditarias del Doctor Lucas, las degenerativas de Max Nordau, y las estéticas de Taine. Santiago Rusiñol demuestra su "desengaño" del Naturalismo y del positivismo cientificista:

Ells (els pobres materialistes) no són, no, ni poden ser modernistes. Ells estan satisfets del món qye veuen i no senten desitjos de canviar ni de provar de millorar-lo; creuen en el present perquè hi viuen i en viuen, i el pervindre els espanta [...] són homes secs, porucs i mandres d'idees; curts de somnis. (Discurso, pág. 611)

Si bien la reacción contra las teorías naturalistas ya había surgido de sus mismos seguidores (Maupassant, etc.) al proclamarse, en 1887, el denominado "Manifeste Cinq". El Naturalismo propugnaba la idea del predominio constante de la observación sobre la imaginación, y la tesis de que el hombre pertenecía al universo en el que estaba sometido a un determinismo causal; por el contrario el Modernismo - como el Romanticismo que reaccionó en contra de las normas de la Ilustración- rompió con la tradición inmediata, y devino respuesta al Positivismo. La función histórica de esta ruptura fue semejante a la respuesta romántica en el alba del siglo XIX. Así continuaba la tradición iniciada por el Romanticismo a favor del individuo y de su sensibilidad personal, como señala Rusiñol en una de las cartas dirigidas a Víctor Balaguer:

Nos une una fe; el amor a la poesía y al arte, y nos une una antipatía; el naturalismo como escuela. Los naturalistas, creo que fueron los que quisieron derrivar el romanticismo, poniéndole por delante un arte, que se fue convirtiendo, al exagerarse, en fotografía al tratarse de pintura, y en inventarlo al tratarse de literatura. (Carta 2 ).

Tras dos decenios de Naturalismo y cuestiones sociológicas, Santiago Rusiñol propone una fórmula válida para lograr la separación del ideal respecto de la realidad circundante, de la llamada "prosa de la vida", como un sacerdocio laico, y el artista como un rebelde social. Es el alegato más extremado que Rusiñol jamás hizo del concepto aristocratizante de "l'art pour l'art", tendencia que, iniciada en el Romanticismo, transcurre por la "vía irracionalista" del arte y culmina en el Modernisme, donde, al extremarla, se consume. Rusiñol, en la misma carta, prosigue:

Los modernistas, al protestar, creo que les vengan a Vdes. Los románticos se dejaron llevar quizás de la imaginación, los modernistas, quizás de la impresión, pero prefiero esto a una escuela que quería convertir el artista en ciencia y quizás hubiera terminado en higiene, estadística, u otra curiosidad cualquiera, muy útil quizás para cierta gente, pero indigna para el arte, que siempre tendrá el encanto de lo vago y lo nebuloso. (Carta 2). 
Por su parte, Víctor Balaguer propone:

que hemos de volver, finalmente, a aquellos tiempos en que el arte no era personal ni utilitario, en que el artista, con nombre o sin él, desdeñando los trompeteos del vulgo y desconociendo los bombos del reclamo, sólo se cuidaba de perfeccionar su obra y de esmerarse en ella, ajeno a toda codicia de lucro, trabajando en el gran alcázar, sin más deseo que el de contribuir a elevar al cielo la aspiración unánime del siglo. (Artículo, pág. 664)

El creador ya se preocupaba más por la problemática del "artista" y el "arte" que por la del "autor" y la "literatura"; con suficiente claridad se traza la estética modernista en los vibrantes párrafos pronunciados por Santiago Rusiñol en el "Cau Ferrat": la aparición de una sensibilidad que no es en realidad nueva, sino que depende, por vinculación, del "post-romanticismo". El arte se convierte en sucedáneo de la religión, se vuelve al ritmo poético como manifestación suprema del ritmo universal, la exaltación del poeta como dignidad de iniciado en la experimentación de vías, en la línea inaugurada ya por el Romanticismo; Rusiñol, en representación de los demás modernistas, confiesa:

que volem ser poetes i que despreciem i planyem an els que no sentin la poesia; que estimem més un Leonard de Vinci o un Dant que una província o un poble; que preferim ser simbolistes, i desquilibrats, i fins bojos i decadents, a decaiguts i mansos; que el sentit comú ens ofega; que, en prudència, a la nostra terra en sobra; que no hi fa res passar per Don Quixots allí on hi ha tants Sancho-Panzas que pasturen, ni llegir llibres d'encantats allí on no s'en llegeix de cap mena. (Discurso, pág. 612)

La estética modernista quedaba manifestada en estos sonoros párrafos escritos por Rusiñol; al exaltar en sincrética forma el individualismo, el espiritualismo, y al abanderar "arte por el arte", la tendencia esteticista y la concepción individualista y prometeica del artista.

Víctor Balaguer, tras la lectura del Discurso, y posiblemente de este fragmento, y embriagado por la fuerza de las palabras, reconoce:

Si esto es, pues, el modernismo, si esto es el impresionismo, entonces yo romántico e idealista de toda la vida, yo, que voté contra el modernismo con Castelar, con Pidal y con Madrazo, entonces anche'io, también yo, también yo soy cristiano. Echadme a las fieras. (Artículo, pág. 664)

Los postulados del movimientos romántico, reaccionario a los fundamentos estéticos del Neoclasicismo y del racionalismo de la Ilustración, trascendieron, y de constituir una estética y una filosofía se convirtieron en una ideología, en una forma de sentir y de vivir. En Cataluña ese fue el inicio conjunto, a pesar de todas las contradicciones posibles, de dos estéticas literarias del siglo XX: el Modernisme y, por otro lado, el Noucentisme. 
Santiago Rusiñol, en la conversación anteriormente citada, y titulada "Modernisme", expresa la necesidad de que en el presente se mire y se valore el pasado, el pasado "artístico', perenne y maestro espiritual:

Per això estimem les coses velles quan són files d'artistes, perquè sòn arrels que han aguantat les tempestats de tants segles; per això estimem el modernisme perquè són branques noves que estiren els braços enlaire; per això estimem un i altre art, ja que l'un és la força que aguanta i l'altre és la nova brotada que aomplirá el cel de flors blanques. [...] Es d'estimar lo bo que els passats feren, perquè els vinents estimim lo que ara fem. Consultar sa experiència i seguir sempre andavant. (Rusiñol, 1976, págs. 614 y 615$)$

El Modernisme, por la ciencia de las correspondencias que es la analogía, tendió un puente entre su estética y su postura implícita y las respectivas del movimiento romántico; así, sin suprimir las distancias ni tampoco anular las diferencias, se puede establecer una mediación o relación de términos análogos entre ambos, porque obviamente, si "la tendència del moderníssim art és beure en les fonts primitives on brolla l'aigua pura i lliure de tot amanerament" indicará Rusiñol. No és també aquest el propòsit del romanticisme?" (Marco, 1983, pág. 38).

\section{BIBLIOGRAFÍA}

ALAS “CLARÍN", Leopoldo. 1892. Ensayos y Revistas 1888-1892, Madrid, s. i.

ALLISON PEERS, E. 1973. Historia del movimiento romántico español, Madrid, Gredos.

ANÓNIMO. 1895. Festa Modernista del Cau Ferrat. Certamen literari celebrat a Sitges el 4 de Novembre de 1984, Barcelona, Tip. "L'Avenç". Hay una reciente edición facsímil: Sabadell, Ausa, 1990.

ANÓNIMO. 1896. "En pro del Modernismo", La Voz de Sitges, 19 Enero, págs. 495-496.

AZNAR SOLER Manuel. 1980. "Bohemia y burguesía en la literatura finisecular", Historia y Crítica de la Literatura Española. Modernismo y 98, Barcelona, Crítica, 1980, vol. 6, págs. 75-82.

CATASUS, Trinitat. 1933. Discurso pronunciado en la inauguración del Cau Ferrat como museo el 16 de Abril de 1933. Reproducido fragmentariamente y en castellano en La Vanguardia, año LII, núm. 21573 (Martes, 18 Abril 1933), pág. 7.

COLL I MIRABENT, Isabel. 1990. Rusiñol, Vilafranca del Penedés, Flama, 1990.

DARÍO, Rubén. España contemporánea, Barcelona, Lumen.

DIAZ-PLAJA, Guillermo. 1953a. Introducción al estudio del romanticismo español, Madrid, Espasa-Calpe, $4^{\mathrm{a}}$ ed.

-. 1953b. Modernismo frente a Noventa y ocho. Una introducción a la literatura española del siglo XX, Madrid, Espasa-Calpe. 
FERRERES, Rafael. 1964. Los límites del Modernismo, Madrid, Taurus.

FUSTER, Joan. 1964. Literatura catalana contemporània, Barcelona, Curial, 1964.

GULLÓN, Ricardo. 1980. El modernismo visto por los modernistas, Barcelona, Guadarrama.

HINTERHÄUSER, Hans. 1980. Fin de siglo (Figuras y mitos), Madrid, Taurus.

JIMÉNEZ, Juan Ramón. 1962. El Modernismo. Notas de un curso. 1953, México, Aguilar.

LITVAK, Lily (ed.). 1986. El Modernismo, Madrid, Taurus.

LLORENS CASTILLO, Vicente. 1980. El romanticismo español, Madrid, Fundación Juan March - Castalia.

MARAGALL, Joan. 1930. “Joan Sardà", Obres Completes, Barcelona, Sala Parés Llibreria, vol. V, págs. 95-108.

-. 1931. "Énfasis literario", Obres Completes, Barcelona, Sala Parés Llibreria, vol. X, págs. 149-153.

MARCO, Joaquim. 1983. El Modernisme literari i d'altres assaigs, Barcelona, Edhasa.

MARFANY Joan Lluís. 1975. Aspectes del Modernisme, Barcelona, Curial.

PARDO BAZÁN, Emilia. 1895. Carta a Santiago Rusiñol tras su visita al Cau Ferrat en Julio de 1895. Reproducido fragmentariamente en La Voz de Sitges, Año II, núm. 83 (28 Julio), pág. 2.

PAZ, Octavio. 1987. Los hijos del limo, Barcelona, Seix-Barral, 1987.

PLA, Josep. 1981. Santiago Rusiñol i el seu temps, Barcelona, Destino.

PLANES, Ramon. 1971. El Modernisme a Sitges, Barcelona, Edicions 62.

- (ed.). 1971. Santiago Rusiñol, Barcelona, Edicions 62.

QUERALT, M" Pilar. 1984. Balaguer, Barcelona, Nou Art Thor.

RAFOLS, J. F. 1949. Modernismo y modernistas, Barcelona, Destino.

RUSIÑOL, Santiago. 1976. Obres Completes, Barcelona, Selecta, vol. II, $3^{\mathrm{a}}$ ed.

SOBEJANO, Gonzalo. 1967. "Épater le bourgeois" en la España literaria de 1900", Forma literaria y sensibilidad social, Madrid, Gredos, págs. 178-223.

SOCIAS I PALAU, Jaume. 1982. Rusiñol, Barceiona, Nou Art Thor.

TUÑON DE LARA, Manuel. 1977. Medio siglo de cultura española (1885-1936), Madrid, Tecnos, $3^{\mathrm{a}}$ ed.

VALENTI, Eduard. 1973. El primer modernismo literario catalán y sus fundamentos ideológicos, Barcelona, Ariel.

VV.AA. 1975. La crisis de fin de siglo: ideología y literatura, Barcelona, Ariel.

YXART, Josep. 1936. “Epistolari de — a Narcís Oller”, La Revista, XXII, págs. 45 y ss. 


\title{
BASES Y TÓPICOS MORALES DE LOS SAINETES DE RAMÓN DE LA CRUZ
}

\author{
Josep María SALA VALLDAURA \\ Universidad de Barcelona
}

Al analizar la ideología de un escritor de sainetes, se corre el riesgo de confundir la "ideología" del sainete con la del autor. Es decir, tales piezas exigen por lo general la presencia de los males sociales sobre los que - sin ánimo de moralizar, o sea, sin pretensiones ideológicas- montar una intrascendente burla. Ramón de la Cruz, como veremos luego, se aparta de tan definitoria y esencial característica, salvo en los entremeses de "figuras". Se podría incluso enunciar que el entremés niega la ideología del autor, por cuanto la encorseta al ser una pieza breve, deliberadamente trivial, de estructura, personajes y temática casi dadas; el amaneramiento reemplaza muchas veces la originalidad, que el espectador no desea.

El papel del público respecto a la moral transmitida por el sainete no puede ser desdeñado: "no pocas veces se observa una subida repentina de las recaudaciones después de la mera sustitución del sainete que completa el programa" (Andioc, 1976, pág. 33). Al autor se le impide en consecuencia discrepar de los receptores de su producto (Sala, 1973), por lo que es frecuente que se inviertan los papeles y sean éstos quienes dicten el mensaje y el código del escritor.

Si se permite la crítica de lo establecido, se debe sólo a que la deformación, la superioridad del espectador sobre lo que ocurre en el escenario y el compartido - por autor y público- propósito de simple pasatiempo difuminan lo que muy superficialmente parece una subversión o una puesta en duda moral. "El entremés acepta alegremente el caos del mundo, ya que su materia especial son las lacras e imperfecciones de la sociedad coetánea y de las mismas instituciones humanas" (Asensio, 1965, pág. 39). El propósito inicial, la esencia del entremés, el papel "fiscalizador" del público [...] invalidaban la potencial crítica dialéctica de dichas obritas. Y si algún "heterodoxo" cultivó el sainete, 
la minoridad de este teatro no dejó translucir aquella heterodoxia más que en escasa medida. De todos modos, el entremés tenía abiertas sus puertas tanto para quienes estaban interesados en el análisis moral de su época (Cervantes, Quevedo) como para quienes, por no haber escrito obras de más enjundia ideológica, no se manifestaron a este respecto (Quiñones de Benavente).

A las dificultades propias del subgénero (el amaneramiento, la deformación ridiculizadora, la brevedad, y un largo etcétera) y a las debidas a la relación entre el texto y el espectador (la mera función de entretenimiento a-moral), cabe añadir otra dificultad que concierne al autor: su dificultad con los personajes, su actitud con ellos. No profundiza en su interior, y por tanto -a la busca de lo típico y con una visión totalmente externa- el entremés observa al personaje "sin más emoción que la que exhibe el coleccionista al examinar sus lepidópteros" (Bergman, 1970, pág. 17). Bastante menos, probablemente.

Hay, con todo, una posible y leve objeción a esta frialdad. Las características que delimitan al entremés obligan a la búsqueda, por parte de sus autores, de lo que se aleje de la normalidad, de lo establecido. Esta necesidad introduce, por ejemplo, la figura del rufián que, por contraste, queda ensalzado al conducirse con sinceridad, valentía y libertad. Forzosamente, había de influir en la ideología de Cervantes y Quevedo el tipo que protagonizara algunos de sus más celebrados entremeses. (No se olvide, tampoco, que son los graciosos quienes interpretan, y a su manera, los papeles principales).

Objeción plausible... pero excepcional. Una de las claves de esa ausencia de ideología, o, en definitiva, de compromiso, está, más allá de la definición y de la tradición entremesiles, en una ausencia de lo subjetivo. Recurramos nuevamente a Eugenio Asensio: "El Siglo de Oro ignora las dos modalidades románticas: el costumbrismo nostálgico, que trata de retener un mundo que se va, y el costumbrismo progresista, que, condenando el atraso social, se dispara hacia un porvenir luminoso y avanzado. Ignora igualmente el costumbrismo documental, la saturación descriptiva del naturalismo, donde el ambiente, y no el hombre, sirve de protagonista" (pág. 140). Quien desee establecer la ideología de un entremesista o de un sainetero habrá, pues, de desbrozar mucho camino, limpiar los presupuestos del género, los dictados del público, la "frialdad" del oficio, etcétera. Podrá servirse de los "entremeses de figuras" si el autor que estudia los ha escrito; así lo hemos hecho con Ramón de la Cruz, pero el panorama ideológico tratado será siempre muy reducido: se limitará a la crítica más o menos tópica de las costumbres, y la lectura tendrá que desandar lo andado, para ver si detrás de la burlesca negación de unos comportamientos se esconde la afirmación de sus contrarios. Tarea difícil, que exige incluso tener presentes las estructuras formales del autor: así, por ejemplo, siempre tendrá en Ramón de la Cruz mayor importancia lo manifestado por ciertos personajes, lo dicho o lo acaecido al final, etcétera. 
La falta de problematización de la realidad en el teatro menor, lejos de disminuir, se acentuó en el siglo XVIII. El acercamiento del entremés, convertido en sainete, a la comedia según la definición moratiniana ${ }^{1}$ procede de la influencia del Neoclasicismo: el teatro ha de ser útil y moralizador. De todos modos, las bases del subgénero estaban trazadas y Ramón de la Cruz las aceptó en su mayor parte: entre ellas, por supuesto, la ridiculización de ciertos tipos (verbigracia, los payos). Esta ridiculización de modales, indumentaria, formas de hablar y de hacer, etc., interesa sobre todo cuando la sátira se centra en personajes no tradicionales: los petimetres, el cortejo, los abates... Burlándose de ellos, se reafirma la vieja moral. Se trata de oponer lo tradicional a lo moderno, lo castizo a lo extranjero. Y la majeza, aunque con algunos defectos, conservaba los antiguos valores españoles de la virilidad y la conciencia del propio valer (el honor), el sentido del ridículo y la pasión correcta, en la opinión de Ramón de la Cruz.

Su reaccionarismo xenófobo y misoneísta contribuyó, quizá paradójicamente, a la liberación del pueblo con respecto a las clases altas, o lo que viene a ser lo mismo: a cierta toma de conciencia social de las clases bajas urbanas. Dejando a un lado estas consideraciones sobre las consecuencias de la ideología de Ramón de la Cruz, lo cierto es que la segunda mitad del siglo XVIII fue escenario de una crisis de la moral tradicional, y en cierto modo de una renovación de las costumbres (del lujo, del concepto de honor, del sentido de la dignidad humana, del consumismo, ...) y que los escritores fueron testigos y parte de aquel proceso. Cabía un progresismo y una mirada de añoranza, un costumbrismo progresista y un costumbrismo nostálgico. Máxime cuando el periodismo abría una ventana a la contemplación de la vida diaria y seguía el sainete, heredero del viejo entremés, asomado a la realidad en busca de lo pintoresco. La crisis de costumbres contribuyó pues a aclarar y a aclararnos el ideario moral de Ramón de la Cruz, de su nostalgia y defensa de los valores nacionales.

A esta relativa claridad sobre la ideología de Ramón de la Cruz, iluminada por circunstancias históricas (influencia de la teoría neoclásica -moralización, utilidad - nacimiento del periodismo, crisis de costumbres y consecuente toma de partido del escritor abocado a la vida cotidiana), se añade la voluntad pedagógica del escritor madrileño que tergiversa en bastantes ocasiones la esencia de lo que había sido hasta entonces el teatro breve. Ramón de la Cruz quiere moralizar e incurre en redundancias ideológicas difícilmente asimilables por la condición sociológica y sobre todo estructural del subgénero publicado,

1. "Imitación en diálogo (escrito en verso o prosa) de un suceso ocurrido en un lugar y en pocas horas entre personas particulares, por medio del cual, y de la oportuna expresión de afectos y caracteres, resultan puestos en ridículo los vicios y errores comunes en la sociedad, y recomendadas por consiguiente la verdad y la virtud" (Fernández de Moratín, 1830, II, pág. XLIII). 
redundancias por lo demás innecesarias para la comunicación de su pensamiento. Sólo la elementalidad del sainete puede coayudar a esta redundancia: escena final como moraleja dialogada o conclusión didascálica a una anécdota típicamente representativa; cultivo del entremés "de figuras" en ataque xenófobo y reaccionario a las costumbres recién importadas; elección de tipos ridículos, enfermos de mal de moda, en detrimento de personajes más tradicionales (padres, maridos al modo "clásico", payos, etc.).

La moralidad del autor de El hospital de la moda no es, como la que Asensio da como característica del entremés, "accesoria e implícita" (pág. 39). Hay un relativo compromiso entre creador y criaturas, entre autor y personajes, una emoción mayor que la del coleccionista de lepidópteros. Otro ataque de la práctica de Ramón de la Cruz a la tradicional teoría de la ecuación entre paso, entremés y sainete. Para resumir: existe un cierto costumbrismo nostálgico en su obra, una cierta "dedicación" ideológica conservadora, tradicionalista.

Una vez ha quedado planteada a modo de cuestión previa la relación entre las "ideas" del sainete y las del sainetista, para no caer en un determinismo excesivo que impida ver el margen de movilidad ideológica de cualquier escritor, incluso al servicio de su público, hay que tener presente el abanico de opciones que le ofrece su época. Se trata también de un análisis sobre el texto y el contexto, con que iluminar desde el campo general de las ideas ilustradas y tradicionalistas el terreno de las sátiras de Ramón de la Cruz. De este modo, podremos comprobar -o al menos ésta es mi esperanza-cómo el sainete y la literatura popularista no implican necesariamente una ideología nostálgica y tradicionalista, pese a decantarse a menudo hacia ella, y podremos, de este modo, abrir la posibilidad de saineteros liberales.

Convertida España en "el esqueleto de un gigante", para usar las palabras de Cadalso, dos opciones se presentan al intelectual del siglo XVIII: intentar erguir o siquiera mantener la debilitada columna vertebral, o procurar crear un nuevo cuerpo. El abanico de ideas ofrecido se extiende desde la nostálgica apología de la época imperial hasta el liberalismo extremo, casi antimonárquico (Abellán, 1984).

El abate Marchena, "primer traductor del Emilio en lengua española" (Defourneaux, 1973, pág. 131n; cfr. Lafarga, 1983), escribe en un Manifiesto a la nación española de carácter prerrevolucionario: "La España está a diez mil leguas de Europa y a diez siglos del décimo octavo" (Elorza, 1971, pág. 38). Parecida idea preside casi toda la obra inglesa de José María Blanco White. El país ha cerrado con doble llave el sepulcro del Cid; ante lo cual, otro "heterodoxo", León de Arroyal, se expresa con sarcasmo: "Desprecia [,España,] como hasta aquí las hablillas de los extranjeros envidiosos, abomina sus máximas turbulentas; condena sus opiniones libres, prohíbe sus libros que no han pasado por 
la tabla santa y duerme descansada al agradable arrullo de los silbidos con que se mofan de ti" ("Pan y toros", ibíd., pág. 31).

Estas ideas del liberalismo antiabsolutista se reflejan -y es lo que mayor interés tiene para nuestro estudio- en la crítica de costumbres que desde la prensa ${ }^{2}$ o la poesía llevan a cabo los pensadores más avanzados. Una lectura de El Censor nos permite conocer cómo Cañuelo, en favor de los derechos de cada ciudadano, critica las prerrogativas nobiliares y la pasividad de clérigos y potentados; Antonio Elorza comenta el discurso diecisiete de El Corresponsal del Censor, debido a Manuel Rubín de Celis, en el que el liberal asturiano pide una igualdad de trato fiscal. "Estamos todavía - afirma Elorza (1970, págs. 229-230) - en el momento en que la revolución burguesa se afirma con carácter universal, más allá de los intereses ideológicos de clase. No. A nuestro modo de ver no es otro el sentido de las contraposiciones de Rubín de Celis que culminan lógicamente en la idealización de las formas de vida populares y el menosprecio de los poderosos entregados al lujo". Tan buena disposición por las clases útiles no podía sino ayudar al desarrollo de la creatividad popular y popularista, a pesar del paternalismo con que se ponía en práctica.

La opinión de Rubín de Celis coincide con la expresada por Meléndez Valdés en "La despedida del anciano":

\author{
$¿$ Destinaste a esclavos viles \\ a los pobres? ¿de otra masa \\ es el noble que el plebeyo? \\ ¿Tu ley a todos no iguala? \\ Sólo es noble ante sus ojos \\ El que es útil y trabaja, \\ $y$ en el sudor de su frente \\ su honroso sustento gana. \\ [...] \\ Ella [la razón] busca, y se complace \\ del artesano en la hollada \\ familia, y sus crudas penas \\ con gemidos acompaña. \\ Allí el triste se conduele \\ del triste, y con mano blanda \\ le da el alivio, que el rico
}

2. "Otros, sin traducir precisamente, no tenían puesta la mira en otra cosa que en importar con más o menos prudencia o temeridad las ideas fundamentales de la secta enciclopedista: así $E l$ Pensador de Clavijo y Fajardo, y con más desenvoltura El Censor, que empezó a salir en 1781, dirigido por los abogados Cañuelo y Pereyra, llegando a contar 161 números, que no se libraron de persecuciones inquisitoriales. El espíritu de estos papeles era abiertamente contrario a las tradiciones españolas, incluyendo en ellas las literarias: así lo mostró la campaña de Clavijo contra los autos de Calderón, la de El Censor contra la Oración apologética de Forner" (Menéndez Pelayo, 1923, VI, págs. 54-55). 
en faz cruda le negara.

Allí encuentra las virtudes,

allí la mujer es casta,

y los obedientes hijos

cual un Dios al padre acatan

mientras en los altos techos

la discordia su impía rabia

sopla, y tras la vil codicia

a todos los vicios Ilama. (Cueto, 1952, II, pág. 256)

También Jovellanos, liberal más moderado, desea un cambio social y critica a la nobleza:
¿Y es éste un noble, Arnesto? ¿Aquí se cifran
los timbres y blasones? ¿De qué sirve
la clase ilustre, una alta descendencia,
sin la virtud?" (Jovellanos, 1987, pág. 245)

A esta frecuente crítica a la nobleza se unía, más veladamente por causa de la Inquisición, la dirigida al clero. Pero no se trataba, en el caso de los ilustrados españoles, de una crítica teológica, sino basada en la inercia científica de la escolástica y en la pervivencia de señoríos eclesiásticos (2591, amén de 1235 abadengos, en el Censo de 1797). Por esta razón, como Richard Herr ha demostrado (1975, págs. 166-194), los ataques por parte de los tradicionalistas al pretendido ateísmo o agnosticismo de nuestros ilustrados se perdían en el vacío de lo inútil, esfuerzo errado.

Fuera la educación ${ }^{3}$ o la economía ${ }^{4}$ el eje motriz de la Ilustración, la mayor parte de quienes se integraron en las sociedades económicas o lucharon por las reformas en el campo político, no pensaba en una revolución. La frase con que Sánchez Agesta define la raíz del pensamiento de Jovellanos es, pues, aplicable a casi todos sus compañeros: "Desde las filas ilustradas del racionalismo reformador, Jovellanos no ha dejado de identificar a España con su religión, su constitución, sus leyes, sus costumbres, sus usos, en una palabra, con su tradición" (1953, pág. 219). De ahí que, con la creencia en una evolución de las estructuras políticas, hubiera rechazado la solución revolucionaria: "Que nada bueno se puede esperar de las revoluciones en el Gobierno [...] Pero sí, escarmentadas [las naciones europeas], prefieren la paz y protegen las artes pacíficas, y sobre todo, la agricultura (la única que puede solidar su poder), evitarán su ruina" (Jovellanos, 1967, pág. 116). (Esta generalizada repugnancia de los liberales por la violencia podría explicar la actitud antirrevolucionaria del sainetero gaditano González del Castillo.

3. "La Ilustración fue ante todo un movimiento educativo" (Gómez Marín, 1969, pág. 156).

4. "La Ilustración en España, por tanto, consiste fundamentalmente en un formidable empeño de regeneración económica” (Palacio Atard, pág. 34). 
Simplemente, el pensador liberal desea restringir los poderes nobiliar y eclesiástico, con lo que garantizar la neutralidad estatal y los derechos de todos y cada uno de los ciudadanos (Elorza, 1970, pág. 41). La cultura no sólo iba a ser fuente de felicidad pública y privada, sino que también iba a dignificar el hombre, por ser instrumento de fraternalización y prosperidad social (Sarrailh, 1954, págs. 145-164). Naturalmente, reconocer como ciudadano a quien hasta entonces no había sido más que vasallo representa la "revisión del honor social, uno de los más significativos exponentes del pensamiento del siglo" (Sánchez Agesta, 1953, pág. 24), revisión que también queda ejemplificada desde otro ángulo por los sainetes.

La "dignificación de los oficios" es, por consiguiente, fruto de un cambio en la perspectiva social de la segunda mitad del siglo XVIII, la traducción jurídica del interés por lo útil y de la animadversión por el ocio del clero alto y la clase rica e improductiva.

Dado el carácter fundamentalmente agrícola de la economía española, la preocupación social de los ilustrados y de las sociedades económicas se pone asimismo de relieve en el estudio de los problemas del campo y del campesino. No sólo se redactan informes como el de la Sociedad Económica de Madrid sobre la Ley Agraria, obra de Jovellanos, sino que incluso el tema entra en la literatura de creación: la epístola VI, "El fílósofo en el campo", de Juan Meléndez Valdés, escrita entre 1785 y 1797, "compara la dura, pero sana vida del campesino, con la muelle y decadente del cortesano" (Marco, 1969, pág. 19), quien concluye: "Meléndez es tanto un poeta anacreóntico, como un poeta didácticosocial, preocupado por el problema del campo, que incorpora a su poesía; un efectivo propagador de los problemas que se planteaban en las Sociedades Económicas de Amigos del País" (pág. 26). Tales sociedades, en efecto, desempeñaron un importante papel en el fomento de la industria popular y la agricultura (Anes, 1969, págs. 11-41). Circunstancias personales, con el tópico del "beatus ille", justifican la afirmación de Emilio Palacios: en Meléndez Valdés, "la naturaleza ya no sólo es el gozo, sino el refugio frente a la destrucción y agresividad de la Corte" (Palacios, 1979, pág. 105). Mientras tanto, el sainete, género literariamente conservador, continúa ofreciendo la imagen tradicional del campesino rudo e ignorante.

Pero los ilustrados sólo constituían una minoría, aunque activa y en la cúspide de la sociedad, en el panorama ideológico de la segunda mitad del siglo XVIII. La ayuda real contribuyó a que sus programas fueran algo más que papel mojado, e incluso pudo influir en la aceptación personal, de todos modos muy relativa, de su puesta en práctica: leyes en favor de los trabajadores manuales y de los campesinos; introducción de nuevos métodos agrícolas; suspensión de los desahucios de tierras; etc., lo atestiguan. 
El drama de las dos Españas. José María Blanco White, lúcido testigo de aquella herida, ve su causa en la lucha entre una educación oscurantista y anacrónica y una formación que intenta basarse en la crítica racional. Así expone en 1831 el conflicto: "Si cualquiera de los dos bandos tuviese suficiente poder para subyugar al otro, la fiebre intelectual del país sería menos violenta y cabría esperar alguna crisis en una fecha próxima; pero ni la Iglesia ni los liberales (pues tales son en realidad las dos facciones opuestas) tienen la posibilidad más remota de desarmar al adversario. La contienda debe prolongarse desgraciadamente por un tiempo indefinido, durante el cual los dos sistemas de educación rivales que existen en el país están condenados a proseguir su obra de convertir a la mitad de los españoles en extranjeros y en enemigos de la otra mitad" (Blanco White, 1974, págs. 298-299). La contienda había de ser ganada, forzosamente, por los partidarios de la ilustración y del liberalismo, pero los ultras conservaban entonces el arma del Santo Oficio, la mayoría de las cátedras universitarias y la inercia e ignorancia temerosas del pueblo.

Si en Europa se intensifica el estudio de la geografía y de la historia política, las ciencias naturales y las matemáticas (Hazard, 1968, cap. VI, esp. pág. 255), el ejemplo dado por Feijoo apenas pudo abrirse camino en la universidad; las páginas que Torres Villarroel le dedica son de lo más revelador. El problema no era nuevo: "la identificación de la ciencia tradicional (reducida a unos menguados restos de Peripato) con la ortodoxia y la hispanidad, la sospecha de que lo extranjero, sobre todo si era nórdico, debía ser anticatólico y antiespañol, se fue forjando durante el siglo XVII, antes de salir a luz en las polémicas del XVIII" (Domínguez Ortiz, 1973, pág. 259). De ahí el empeño con que los científicos racionalistas españoles intentan deslindar religión y ciencia.

Francia representaba la heterodoxia política y científica, religiosa y moral. También literariamente, su influencia es rechazada por Forner en las Exequias a la lengua española y Tomás de Iriarte en Los literatos en Cuaresma. Nipho se esfuerza en hacer frente a las innovaciones desde la prensa. Valcárcel, Alcántara Castro, Ceballos... procuran rebatir las ideas antiescolásticas, el enciclopedismo y lo que denominan jansenismo. La Oración apologética por la España y su mérito literario (1786) se convierte en la biblia de los tradicionalistas y en el blanco de los liberales (Cañuelo escribe en el discurso 165 de El Censor una satírica Oración apologética por el Africa y su mérito literario); a España, según Juan Pablo Forner, se debe el correcto desarrollo de la ciencia y de la cultura en general.

Sin embargo, el misoneísmo y la xenofobia, faltos quizá de una sólida argumentación científica, se refugian en terrenos más superficiales y cotidianos: la "decadencia" de las costumbres, al abrigo de un probablemente mal 
entendido celo religioso. La generalización progresiva en los sectores altos, y en alguna gente de la clase media por imitación, de la costumbre del chichisveo, corre paralela al incremento en número e intensidad de las voces contrarias a dicha boga. A pesar de que la actitud del Santo Oficio, en opinión de Martín Gaite (1972, págs. 181 ss.), fue la de echar tierra al asunto y eludir el conflicto con la alta sociedad. Sirven como ejemplo de tan constante crítica a la "corrupción" las cartas del marqués de la Villa de San Andrés, escritas a mediados del siglo; así se lamenta: "Mas ahora que no sólo el pie, sino mucho más allá, a merced de las contradanzas y a favor de los tontillos, ve el que tiene ojos; que la mano en los minuetes y ambas manos coge, oprime y suelta el atrevido; que al tocador entra todo pisaverde; que el pariente o conocido, si viene forastero, abraza y en las mejillas (ahí es nada) besa; que todas las deidades tragan vino [...]" (Domínguez Ortiz, 1973, pág. 111).

Con todo, y aunque en materia filosófica, religiosa, política, científica y literaria, los apologetas del tradicionalismo y los ilustrados disentían totalmente, con aparente paradoja la sátira a los petimetres, a los abates eruditos a la violeta, al cortejo, va a ser común. Puede que tal coincidencia suponga cierta contradicción ideológica por parte de los ilustrados ${ }^{5}$, pero por lo general respondía a una convergencia de dos actitudes: los tradicionalistas velaban por "aquella modestia y gravedad que era propio del carácter de la nación"; los ilustrados criticaban el ocio inútil de la nobleza y grupos miméticos o asimilados. La coincidencia final - distintos los tratamientos de ambas críticas- abarca no sólo la burla de cierto esnobismo sin base (irracional para unos; inmoral para otros) sino la sátira a la nobleza, a ciertos conceptos del honor y de los celos, e incluso, aunque más forzadamente, a la crítica de la ignorancia de la sociedad rural.

Si Nicolás Fernández de Moratín escribe La Petimetra o Cadalso toma por tema para sus octavas la descripción algo burlesca del traje de un currutaco, a Juan Pablo Forner se atribuyen estas dos definiciones:

Definición de una niña de moda.

Yo soy de poca edad, rica y bonita; tengo lo que llamar suelen salero, y toco, y canto, y bailo hasta el bolero, $\mathrm{y}$ ando que vuelo con la ropa altita;

5. "Desde este punto de vista el fenómeno del desprestigio del matrimonio se relacionaba casi siempre con la corrupción de costumbres reinante y la pérdida del sentimiento del honor. Sin embargo, muchos de los escritores que se dolían de esta pérdida no reparaban en la contradicción que suponía llorar por el honor de los maridos españoles, cuando este cambio de mentalidad era una consecuencia de la apertura hacia el extranjero y del amor al progreso que estos mismos escritores ilustrados enaltecían, y que era la consigna de los gobiernos de la época" (Martín Gaite, 1972, pág. 131). Por otra parte, Meléndez Valdés, Tomás de Iriarte, Forner, Samaniego... cultivaron la poesía erótica. 
si entro en ella, devuelvo una visita, y más si hay militar o hay extranjero; voy a tertulia, y hallo peladero;

a paseo y me llevo la palmita: soy marcial ${ }^{6}$ : hablo y trato con despejo; a los lindos los traigo con ejercicio, y dejo y tomo a mi placer cortejo; visto y peino con gracia y artificio... Pues, ¿qué me falta?... Oyóla un tío viejo, y le dijo gruñendo: Loca, el juicio.

Definición de un petimetre.

Yo visto, ya ve usted, perfectamente; mis medias son sutiles y estiradas; las hebillas, preciosas y envidiadas; los calzones, estrechos sumamente: charretera a la corva cabalmente; mis muestras, de Cabrier, muy apreciadas; mis sortijas, en miles valüadas; sombrero de tres altos prepotente: sé un poco de francés y de italiano; pienso bien, me produzco a maravilla; soy marcial, a las damas muy atento: ¿Tengo, señor, razón de estar contento? ¿Qué me falta?... No más que una cosilla: temor de Dios y algun entendimiento. (Cueto, 1952, II, pág. 319).

Las diatribas de "El petimetre" de Iriarte censurándolo por su ociosa inutilidad son parecidas, e incluso en el final del soneto, este autor pone también en duda la racionalidad de tal comportamiento.

La comedia de magia y la de figurón, para ir descendiendo por los peldaños de la literatura poco considerada, zahieren de forma semejante, ya en El anillo de Giges, y el máxico rey de Lidia de José de Cañizares:

Soy de la nueva doctrina que de reñir por mugeres es una gran bobería, con que de puro prudentes son ya los hombres gallinas. (Apud Caro Baroja, 1974, pág. 109).

El figurón linajudo, procedente del Norte - conio estudia el propio Baroja (pág. 410)—, es ridiculizado por su vanidad nobiliaria, su credulidad, su avaricia, desde mediados del siglo XVII, pero continúa dando lugar a comedias y sainetes a lo largo del todo el XVIII porque no pierde su vigencia o comicidad

6. "Marcialidad" significaba "desenvoltura, despejo". 
hasta avanzado el siglo XIX. Coinciden, pues, en el panorama de la segunda mitad del siglo de las Luces, la sátira ilustrada, la tradicional y aun la literariamente tópica.

Las conclusiones de tal convergencia crítica son de la mayor importancia para el presente estudio: el tema satírico de las nuevas costumbres, tan frecuente en los sainetes de Ramón de la Cruz y González del Castillo, no presupone una determinada ideología. Si el autor madrileño defiende, a trasmano de la raíz amoral del teatro que escribe, una moral tradicionalista, ello no obsta para que otro sainetero realice su sátira con unas bases distintas. Por tanto, la burla del cortejo y del petimetre no denota ni mentalidad conservadora ni mentalidad liberal. Sólo un análisis de la actitud que adopte el sainetero al tratar el tema detectará su ideología.

Afirmábamos que el conservadurismo estético de los géneros popularistas fomenta, sin imponerla, la ideología tradicionalista y la simple repetición de una manera, al amparo, además, de la escasa ambición literaria de su público. Tal vez igual efecto tiene el desprestigio moral del sainete (Palacios Fernández, 1983, págs. 215-233). Lo mismo ocurría con la literatura popular, y de ahí que "viva marginalmente cualquier transformación de la literatura culta, a menos que ésta signifique una honda y amplísima variación de gusto [...] El débil neoclasicismo español no logra hacer mella ni en la temática ni en los gustos populares, si exceptuamos los poemas de Cadalso, popular por diversos motivos, aunque no por su neoclasicismo" (Marco, 1977, I, pág. 245). Once días, por ejemplo, duró tan sólo en el Príncipe de Madrid Los menestrales, la más importante iniciativa teatral neoclásica e ilustrada en pro de los artesanos... y, para más inri, presentada por una loa de Ramón de la Cruz. Por tanto, al reflexionar acerca de las bases y tópicos morales de los sainetes popularistas del autor madrileño, conviene indicar que la ridiculización con que presentaba a los payos procedía de la tradición entremesil; que la crítica a las clases media y alta se centraba en sus costumbres (modo de comportarse, de hablar y de vestir) y en el ataque a su maledicencia, hipocresía y esnobismo. No quiere esto significar que Ramón de la Cruz deseara un cambio social; abunda en lo mismo Nigel Glendinning (1973, págs. 173-174): "prefirió mantener la disposición jerárquica de la sociedad española como siempre había sido. Se critica menos el absentismo de los propietarios de Las frioleras, por ejemplo, que los nuevos ricos de los pueblos rurales y los egoístas inmorales que no reconocían valores y no sentían ninguna consideración hacia los demás".

A pesar de la no aceptación de la fanfarronería, Ramón de la Cruz encuentra entre los majos la continuidad de las virtudes de nuestra época áurea (Caro Baroja, 1975, págs. 281-349). Se cumple en él el mismo rechazo al “afeminamiento', rechazo que llevó a los majos a exagerar su apariencia 
machista y a considerarse salvaguardadores de la tradición. Así también lo debió creer nuestro sainetero, y así lo expone Martín Gaite (1972, págs. 63-64): "Los hombres de los barrios bajos, como revancha a su miseria, se atrincheraron en aquella xenofobia y acentuaron su desprecio hacia los petimetres ricos. Se consideraban superiores a ellos, y llegaron a creerse depositarios y genuinos representantes del espíritu castellano en sus más puras esencias. Despreciaban especialmente a la clase media [...], que era la principal culpable de la degeneración caricaturesca de las nuevas modas".

La opinión de Ramón de la Cruz quizá coincida con la del manchego que, después de su visita a Madrid, concluye:

\author{
MERINO. Vayan, y vamos nosotros \\ contentos a festejarnos, \\ de haber conocido a tiempo \\ que en el lugar en que estamos \\ lo más del oro, que brilla, \\ es aparente, o es falso.
}

(Cruz, 1985, Los usías contrahechos, pág. 199).

Pero cuando prefiere moralizar — con una actitud, según hemos escrito, contraentremesil y didáctica, por influencia del neoclasicismo--, no recurre a los majos; don Ramón de la Cruz escoge como portavoz de sus ideas a un hombre acomodado, un hidalgo a la vieja usanza o un personaje simbólico. Prosigue, incluso, una escasa tradición: la del entremés de "figuras" (Asensio, 1965, págs. 77 ss.), para hacer desfilar una serie de entes ridículos ante los ojos de un caballero juicioso que muestra las ideas del autor. José-Francisco Gatti enumera los siguientes sainetes de "figuras" debidos a Ramón de la Cruz: La feria de la fortuna, El hospital de la moda, La academia del ocio, El hospital de los tontos y El almacén de las novias (De la Cruz, 1972, pág. 23). En La academia del ocio, Espejo indica el "sujeto" que está buscando:

ESPEJO. El más perfecto, sea militar, golilla o artesano, como tenga buen juicio y limpia mano, que tenga horror al ocio y sea familiar de su negocio y no de los ajenos; porque arguyo que los tales jamás cuidan del suyo.

BLAS. ¿Si es hombre bajo?

ESPEJO. Como sea prudente, honrado y hábil, él será eminente; que la virtud no siempre da blasones y los dan cada día los doblones. (Cruz, 1915, I, pág. 58) 
En El almacén de novias (entre las que figura, rara avis, una dama estudiosa y erudita), el Pretendiente quiere hallar una mujer "santa, noble, hermosa y rica" (Cruz, 1928, II, pág. 404).

El buen juicio (o la prudencia, o la honradez) y la santidad, para Ramón de la Cruz, se han refugiado en quienes persisten en el camino de "nuestros abuelos". Tal mención -o la de Forner: "un tío viejo", en el poema transcrito anteriormente - indica cuál es el punto de partida del autor y, por esto, se le "lleva la pasión..."

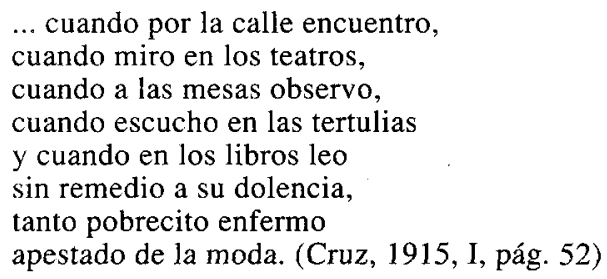

Quien así habla, un hidalgo, viste "a la española antigua rigurosamente" y funda El hospital de la moda para curar afrancesados en el hablar, en el vestir o en el escribir. Los majos, que emplean "su lengua" y saben sólo seguidillas y tonadas, están sanos y libres de todo contagio.

La moda ha convertido el matrimonio en hazaña de valientes, pues la falta de medida de ciertas mujeres exige un cirineo (léase petimetre) que ayude económicamente; tal inmoralidad representa para Ramón de la Cruz el olvido del antiguo y legítimo honor, del recato de la dama y el de los celos.

El petimetre o el cortejo cifran su valía en la oportunidad de satisfacer un capricho de la dama, en conocer la moda, en vestir a la francesa y a la última, en aconsejar al perruquier, en saber dirigir un baile, etc. (véase, por ejemplo, $L a$ elección del coriejo). Ante la señora Moda, que "fomenta / el genio raro de las damas locas / con muchas batas y camisas pocas" (Cruz, 1915, La Academia del Ocio, 1, pág. 57), ¿cuál ha de ser la actitud del marido?:

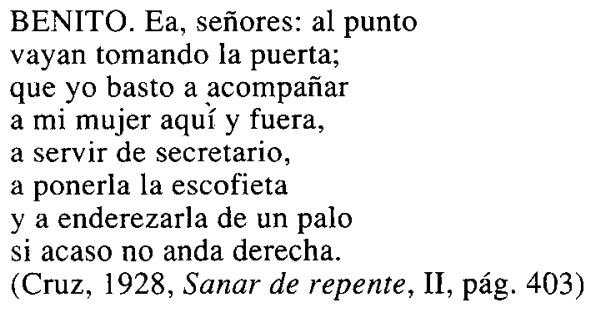

¿Cuál la del caballero honesto?: 
DON MODESTO: [...] y quien las mira con casta

intención evitar debe, con razón cuerda y cristiana, el riesgo que le engañen y el delito de engañarlas.

(Cruz, 1972, El petimetre, págs. 72-73)

Los finales moralizadores abundan en la obra de Ramón de la Cruz: a la postre sabemos que el marido hará valer su autoridad y, en muchos casos, que la esposa rechazará la extranjera e inmoral costumbre del cortejo. En la última escena de El marido discreto (repárese en el título el uso de un adjetivo tan propio de la edad de Oro), don Santos desea que

\author{
[...] algunas se estremecieran \\ o de vergüenza o de asco \\ y volvieran a querer \\ sus maridos a dos manos. (Cruz, 1972, pág. 293)
}

Los sainetes de Ramón de la Cruz permiten, sin embargo, una mayor hondura interpretativa. Creo que la causa de la corrupción de costumbres estaría, según la opinión del autor madrileño, en la mujer. Don Modesto, en El petimetre, así lo pone de manifiesto:

La culpa la tienen aquellas
que han puesto en tan bajo precio
los favores, que cualquiera
puede haberlos, y las cosas
se estiman conforme cuestan. (Cruz, 1972, págs. 84-85)

El dinero y su necesidad han contribuido decisivamente a este proceso de degradación. En La oposición a cortejo, sorprende a la ingenua y recatada Laura la mala crianza y educación de la gente bien vestida, cuando su madre le busca cortejo:

\author{
DOÑA OROSIA. [...] ;Honra! No tuvieron nada \\ más de sobra sus abuelos; \\ pero yo y mi chica más \\ necesitamos dinero.
}

DOÑA LAURA. ¡Oh, qué mal piensa mi madre! (Cruz, 1972, pág. 229)

La sátira al cortejo, los petimetres, abates, usías, poetas afrancesados, peluqueros...es, en el caso de Ramón de la Cruz, reflejo de una moral tradicionalista. Sin embargo, la caricaturización en el tratamiento de los tipos y la coincidencia en diversas críticas morales a las clases media y alta de tradicionalistas e ilustrados indujeron a Agustín Durán (1843) a leer a Ramón de la Cruz como afecto a las nuevas ideas, lo que también ha sido defendido más recientemente: el sainetero madrileño "consiguió hacer llegar a esa gran masa 
amorfa muchos de los principios de unos ilustrados, cuyos libros, discursos y proclamas se veían la mayor parte de las veces restringidos a estrechos círculos pertenecientes a las clases más pudientes de la sociedad" (Vilches de Frutos, 1984, pág. 181 y Caldera, 1978). En realidad, cuando el tema o el comportamiento no le exige una respuesta más personal, es decir, cuando el sainete discurre parcial o totalmente al margen de la sátira de las nuevas costumbres, Ramón de la Cruz adopta la base tradicional literaria, la propia de los entremeses; la ridiculización del hidalgo de lugar en El peluquero soltero (como la del protagonista de Los jugadores, de González del Castillo) puede entroncarse con piezas cortas de Cervantes; las burlas del médico disparatado y de la justicia mercenaria eran frecuentes en el XVII; la figura del payo se remonta hasta casi el más antiguo teatro castellano del que hay noticia; ... Desde su particular apología tradicionalista, Ramón de la Cruz se inquieta por algunos hábitos españoles pero, sobre todo, por la adopción de nuevos hábitos, lo cual confiere a su obra un especial didactismo, una rara —en el sainete-inquietud:

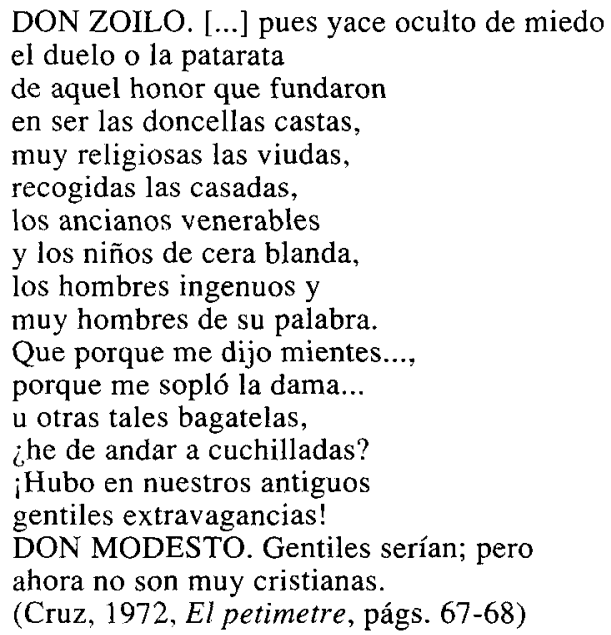

Para mayor abundamiento, los sainetes que abordan cuestiones teatrales (La crítica o El poeta aburrido) o bien parodian un género neoclásico (especialmente Manolo, Inesilla la de Pinto y El Muñuelo) o corroboran, desde el punto de vista estético y literario, lo que acabamos de observar en el campo de la crítica de los usos y costumbres. Como señala Luciano García Lorenzo (1988, pág. 210), ninguna obra es "inocente", y las burlescas "persiguen, a través de la caricatura, de la mascarada, de la pintura, grotesca, de tipos y situaciones, ridiculizar unos gustos - una estética- determinados y defender, a través de otra estética, el grupo social que demanda en el escenario esas obras". También, pues, por este camino paralelo Ramón de la Cruz sirve el 
conservadurismo de su público. Por él revelará cierta simpatía, aunque, por ejemplo, critique la rapidez con que algunos gastan su jornal o la fanfarronería ociosa de otros, mientras que desaprobará la clase media alta, que ha perdido en aras de la mímesis y el afrancesamiento su personalidad y españolismo. No interesa aquí averiguar si Ramón de la Cruz generaliza en exceso, sino poner punto final a esta aproximación a la ideología de quien fuera maestro de los saineteros de finales del XVIII, con la opinión de Arthur Hamilton (1926, pág. 366): "A thorough reactionary, he believed that in the past and only in the past, lay the greatness of Spain, and therefore that all customs of that past were excellent, and all changes and innovations of his own day were, ipso facto, to be condemned" ". Los sainetes de González del Castillo o acaso los de Comella nos hubieran mostrado que el sainete puede servir en parte como vehículo de un pensamiento más avanzado.

\section{BIBLIOGRAFÍA}

ABELLÁN, José Luis. 1984. Historia crítica del pensamiento español, Madrid, Espasa-Calpe, t. III.

ANDIOC, René. 1976. Teatro y sociedad en el Madrid del siglo XVIII, Madrid, Fundación Juan March / Castalia.

ANES, Gonzalo. 1969. "Coyuntura economica e Ilustración : Las Sociedades de Amigos del País", Economía e "Ilustración" en la España del siglo XVIII, Barcelona, Ariel, págs. 11-41.

ASENSIO, Eugenio. 1965. Itinerario del entremés, Madrid, Gredos.

BERGMAN, Hannah E., ed. 1970. Ramillete de entremeses y bailes (siglo XVII), Madrid, Castalia.

BLANCO WHITE, José María. 1974. Obra inglesa, Barcelona, Seix Barral.

CALDERA, Ermanno. 1978. "Il riformismo iluminato nei Sainetes di Ramón de la Cruz", Letterature, 1, págs. 31-50.

CARO BAROJA, Julio. 1974. Teatro popular y magia, Madrid, Revista de Occidente.

—. 1975. "Los majos”, C Ha 299, págs. 281-349; recogido en Temas castizos, Madrid, Istmo, 1980, págs. 15-101.

CRUZ, Ramón de la. 1915 y 1922. Sainetes (ed. E. COTARELO y MORI), Madrid, N.B.A.E. XXIII y XXVI, Bailly / Bailliere, ts. I (1915) y II (1922).

-. 1972. Doce sainetes (ed. José-Francisco GATTI), Barcelona, Labor.

-. 1985. Sainetes (ed. Mireille COULON), Madrid, Taurus.

7. "Como un perfecto reaccionario, pensaba que en el pasado y únicamente en el pasado, se encontraba la grandeza de España y, por lo tanto, que todas las costumbres de ese pasado eran excelentes, y que todos los cambios e innovaciones de su época cran, ipso facto, condenables". 
CUETO, Leopoldo Augusto de, ed. 1952. Poetas líricos del siglo XVIII, Madrid, B.A.E. LXIII, Atlas, 1952, t. II.

DEFOURNEAUX, Marcelin. 1973. Inquisición y censura de libros en la España del siglo XVIII, Madrid, Taurus.

DOMÍNGUEZ ORTIZ, Antonio. 1973. Hechos y figuras del siglo XVIII español, Madrid, Siglo XXI.

DURÁN, Agustín. 1843. "Discurso preliminar" a Colección de sainetes tanto impresos como inéditos de D. Ramón de la Cruz, Madrid, Imp. de Yenes.

ELORZA, Antonio. 1970. La ideología liberal en la llustración española, Madrid, Tecnos.

_-, ed. 1971. "Pan y toros" y otros papeles sediciosos de fines del siglo XVIII, Madrid, Ayuso.

FERNÁNDEZ DE MORATÍN, Leandro. 1830. Comedias originales, Madrid, Real Academia de la Historia, Imp. Aguado, t. II.

GARCÍA LORENZO, Luciano. 1988. “Actitud neoclásica ante la parodia”, Coloquio internacional sobre el teatro español del siglo XVIII. Bolonia, 15-18 de Octubre de 1985, Abano Terme, Piovan, págs. 203-211.

GLENDINNING, Nigel. 1973. El siglo XVIII, t. IV de Historia de la literatura española, Barcelona, Ariel.

GÓMEZ MARÍN, José Antonio. 1969. "La reforma agraria y la mentalidad ilustrada”, C Ha 229, págs. 151-161.

HAMILTON, Arthur. 1926. A Study of Spanish manners 1750-1800 from the plays of Ramón de la Cruz, University of Illinois studies in Language and Literature, XI, 3 .

HAZARD, Paul. 1968. Pensamiento europeo en el siglo XVIII, Madrid, Guadarrama.

HERR, Richard. 1975. España y la revolución del siglo XVIII, Madrid, Aguilar.

JOVELLANOS, Gaspar Melchor de . 1967. Diarios, Madrid, Alianza.

-. 1987. Escritos literarios (ed. J. M. CASO GONZALEZ), Madrid, Espasa-Calpe.

LAFARGA, Francisco. 1983. Las traducciones españolas del teatrofrancés (1700-1835), Barcelona, Universidad.

MARCO, Joaquín. 1969. "El nuevo sentido del campo en la poesía de Meléndez Valdés", Escritos literarios, Barcelona, Taber, págs. 15-26.

- 1977. Literatura popular en España en los siglos XVIII y XIX, Madrid, Taurus, 2 ts.

MARTÍN GAITE, Carmen. 1972. Usos amorosos del dieciocho en España, Madrid, Siglo XXI.

MELÉNDEZ VAldÉS, Juan. 1979. Poesías (ed. Emilio PALACIOS), Barcelona, Alhambra.

MENÉNDEZ PELAYO, Marcelino. 1923. Historia de las ideas estéticas en España, Madrid, Plus Ultra, t. VI.

PALACIO ATARD, Vicente. 1964. Los españoles de la Ilustración, Madrid, Guadarrama. PALACIOS FERNÁNDEZ, Emilio. 1979. Vid. MELÉNDEZ VALDÉS, Juan. 1979. 
- 1983. "La descalificación moral del sainete dieciochesco", El teatro menor en España a partir del siglo XXI, Madrid, C.S.I. C., págs. 215-233.

SALA, Josep Maria. 1973. "Ramón de la Cruz entre dos fuegos: literatura y público", Ha 277-278, págs. 350-360.

SÁNCHEZ AGESTA, Luis. 1953. El pensamiento político del despotismo ilustrado, Madrid, Instituto de Estudios Políticos.

SARRAILH, Jean. 1954. L'Espagne éclairée de la seconde moitié du XVIllème siècle, París, Imprimerie Nationale.

VILCHES DE FRUTOS, María Francisca. 1984. "Los sainetes de don Ramón de la Cruz en la tradición literaria. Sus relaciones con la Ilustración", Segismundo, 39-40, 


\title{
PERIODIZACIÓN Y CRONOLOGÍA DE LA POESÍA SETECENTISTA ESPAÑOLA
}

\author{
Russell P. SEBOLD \\ University of Pennsylvania
}

Considero esencial para la periodización correcta la consulta de las opiniones de época. Es historiográficamente inexacto dividir el gran territorio del pasado en parcelas sin preguntar a sus mismos habitantes por sus moradas; porque esos señores modelaron y vivieron las letras de ese pasado. Nunca he sido partidario de la práctica ususal de dividir siglos, estilos o aun la obra de literatos individuales en casillas estrechas y herméticas. Es absurdo suponer que tan inflexibles delineaciones puedan en cualquier momento de la historia servir para describir las infinitas posibilidades que quedan abiertas a la naturaleza humana, menos aún a la creatividad humana. La literatura se desarrolla en grandes tendencias generales, respondiendo al enfoque gradualmente cambiante de la mentalidad humana, con muchos entrecruzamientos entre tendencias viejas y tendencias nuevas, así como numerosos intentos fracasados de disidentes de iniciar tendencias contrarias. No cabe mayor precisión que señalar que hacia cierto momento histórico una de las grandes tendencias literarias se hace más dominante que las otras durante algunos años, lo cual no significa en modo alguno que dejen de existir en esos mismos años otras alternativas de creación de la más alta calidad. No intentaré conciliar mis ideas sobre la periodización del Neoclasicismo y el Romanticismo con otros esquemas de periodización que se han propuesto en los últimos años; porque yo considero que éstos son intrínsecamente falsos.

Como punto de partida para el esquema de periodización que quisiera proponer hoy, vamos a examinar dos esquemas antiguos: uno del siglo XVII y otro del siglo XVIII. De donde se deduce que a mi parcer el fenómeno neoclásico se remonta mucho más en el tiempo de lo que suele decirse. Esto último es importante tenerlo muy en cuenta. pero antes de pasar al examen de 
los aludidos ejemplos de la periodización antigua, ruego al lector me acompañe en echar una ojeada al mucho más limitante concepto de la periodización que ha imperado en ciertos centros de estudio e investigación durante los últimos veinte años.

En 1970, en el cuaderno 22 de la Cátedra Feijoo, titulado Los conceptos de Rococó, Neoclasicismo y Prerromanticismo en la literatura española, uno de sus tres autores, José Miguel Caso González, distingue tres grupos generacionales en la literatura de la segunda mitad del siglo XVIII y los relaciona a la vez con varias corrientes o escuelas que él ve como dominantes hacia diferentes fechas. Caso define dos veces los cotos cronológicos que considera significativos para las referidas generaciones y escuelas, una vez al comienzo de su ensayo y otra vez al final:

Todo esto --dice, aludiendo a sus observaciones anteriores - significa que entre 1760 y 1775 predomina una estética de gusto Rococó, que entre 1775 y 1790 hay un período de afirmación del Prerromanticismo, y en el que nace el Neoclasicismo, y que entre 1790 y 1810 se producen las obras más claramente prerrománticas, al mismo tiempo que las primeras neoclásicas de alguna importancia. (Caso González, 1970, pág. 11)

Los autores que nacen en torno a 1735, y cuyas obras principales se escriben entre 1760 y 1770 , constituyen fundamentalmente el grupo rococó; los nacidos en torno a 1750 , cuyas obras más importantes aparecen entre 1770 y 1790 , forman un grupo de transición, educado en el Rococó, pero que avanza al Prerromanticismo o que anuncia el neoclasicismo; en los nacidos en torno a 1762, cuyas obras son posteriores a 1790 , encontramos ya a los autores decididamente neoclásicos. (ibíd., pág. 29) ${ }^{1}$

En el primero de los pasajes que hemos citado, se pretende que "entre 1790 y 1810 se producen las obras más claramente prerrománticas”. Si esto es así, ¿qué hacemos con las Noches lúgubres y la anacreóntica "En lúgubres cipreses" de Cadalso, El delincuente honrado de Jovellanos, El precipitado de Trigueros, el poema "A la mañana, en mi desamparo y orfandad" de Meléndez Valdés, la Fiesta antigua de toros en Madrid de Moratín padre, la "Epístola de Jovino a Anfriso, escrita desde el Paular" de Jovellanos, etc.? Pues todas estas obras, que son romantiquísimas, se componen entre 1770 y 1780 . En su libro

1. Posteriormente, Caso ha vuelto sobre la misma cuestión, introduciendo alguna matización pero sin alterar fundamentalmente el esquema de periodización que había propuesto en 1970 (véase Caso González, 1980 y 1983). En las líneas siguientes no hablaré de la poesía rococó, pues este término me parece poco claro para la caracterización del estilo poético y totalmente innecesario para la aclaración de la periodización. Sobre el Rococó sigo pensando lo mismo que hace varios años: "En su reencarnación dieciochesca la anacreóntica, la égloga, o cualquiera de los otros géneros antiguos puede muy bien ser secundariamente rococó, pero sin que fuera primero neoclásico que rococó, ni aun sería anacreóntica, égloga, epitalamio, etc." (Sebold, 1982, págs. 318-319). 
La poesía del siglo ilustrado (1981), Joaquín Arce abraza la opinión de Caso de que en España el Prerromanticismo antecede al Neoclasicismo, pero da un terminus a quo más exacto para la tendencia romántica situando su principio hacia 1770. Sin embargo, no se allana así otro grave obstáculo para el entendimiento de la relación entre el Neoclasicismo y el Romanticismo. Si las teorías de Caso y Arce fueran ciertas, España sería el único país de Occidente en el que las corrientes clásicas o neoclásicas no precedieran a las románticas. No obstante, sin el estímulo combinado del Neoclasicismo y la filosofía de la Ilustración, no habría sido posible el nacimiento del Romanticismo. Sobre tal evolución se han compuesto estudios muy conocidos a partir de los primeros decenios de este siglo: para la literatura francesa, por ejemplo, los de Louis Reynaud, Paul Van Thiegem y André Monglond. Sobre la innegable deuda del Romanticismo español son las corrientes ilustradas y neoclásicas anteriores a 1770 , yo he publicado varios estudios que considero firmemente documentados.

Lo más difícil de explicar, empero, en los esquemas de periodización de Caso y Arce es la colocación del Neoclasicismo al final de todo el siglo XVIII, en oposición a la visión tradicional de la periodización neoclásica, según la que dicho movimiento se inauguraba con la publicación de la Poética de Luzán, en 1737; visión que yo mantengo todavía, aunque con matizaciones. Quien caracteriza con más detalle ese Neoclasicismo supuestamente tan tardío es Arce. Para él empieza el movimiento neoclásico en 1780 , y se extiende hasta 1833 —un año antes del supuesto principio "oficial" del Romanticismo según los viejos manuales-; porque en ese año muere Manuel de Cabanyes, "un puro neoclásico del siglo XIX" (véase Arce, 1981, págs, 503-515). Mas tal calificativo aplicado a Cabanyes da origen ya a graves dudas porque otros han visto en el malogrado poeta catalán otro carácter literario muy diferente. Edgar Allison Peers le considera romántico en su edición de 1923, y hace varios años yo publiqué un trabajo titulado "Manuel de Cabanyes: lírico romántico en la encrucijada"'.

Arce no quiere reconocer la existencia de obras poéticas neoclásicas que sean anteriores a 1780 , porque a partir de ese año se dan en la pintura de algún país europeo tendencias que la crítica reciente ha caracterizado como neoclásicas, y porque, dice él, "el fenómeno neoclásico, en efecto, debiera limitarse en su acepción haciéndolo equivaler al uso que de él hacen los historiadores del arte, de cuyos estudios procede". (Arce, 1981, pág. 25). Esto último no es nada cierto; pues el adjetivo neoclásico se aplica al período de la poesía inglesa que se extiende desde la madurez de Dryden hasta la muerte de Johnson, esto es, aproximadamente de 1660 a 1780 , y el término viene usándose en lengua

2. Véanse Peers, 1923, especialmente el apartado "The Dawn of Romanticism: Cabanyes as Poet and Translator" págs. 16-39; y Sebold, 1984. 
inglesa desde el decenio de 1880; y en efecto, viene utilizándose en español desde el mismo decenio, cuando aparece en la crítica literaria de Menéndez Pelayo (citado, curiosamente, por el mismo Arce 1981, pág. 467). Por lo tanto, no hay que apoyar el uso literario del término neoclásico ni su referencia cronológica en recientes estudios italianos de la pintura, como lo hace Arce. $U t$ pictura poesis: la comparación de un poema determinado con una pintura determinada resulta muchas veces iluminadora para la crítica; mas la forzosa imposición de la historiografía de la pintura a la poesía no puede llevar sino a deformaciones.

Si Arce hubiera reconocido el título de patriarca del Neoclasicismo español que se le viene concediendo a Luzán desde el mismo siglo XVIII, habría tenido que aceptar el año 1737, en el que se publicó la Poética, como fecha clave para la periodización del movimiento neoclásico; y habría venido al suelo toda su estructura cronológica en torno al incipit de 1780; estructura que -para colmo- había levantado sobre unos mal seguros cimientos extraliterarios. En la crítica de los años cuarenta y cincuenta de nuestro siglo se estilaba hacer la singular afirmación de que Luzán había sido tan completamente clásico, que los neoclásicos no encontraban lo que querían en su $P$ oética, como si el primer paso para ser neo-clásico no fuera el ser clasicista y saturarse de todo lo clásico. Arce no llega a tal extremo. En efecto: afirma la potencialidad de la magna obra crítica de Luzán para influir sobre todo su siglo; mas en seguida, sin ofrecer ninguna nueva documentación, niega que la primera edición de la Poética de hecho influyera sobre los poetas. "En 1737, escribe, se publica la primera edición de la Poética, de Luzán. La base estética de la actitud clasicista, típica del siglo, está ya en esta obra. Sin embargo, en esta primera edición, tuvo escaso influjo" (Arce, 1981, pág. 188). No niega Arce, en cambio, el influjo de la segunda edición de la gran obra luzanesca, porque ésta se realiza en 1789 , y esta fecha cae dentro de los cotos neoclásicos que él propone. Cuatro años antes de la publicación de La poesía del siglo ilustrado, de Arce, en el Prólogo a mi edición de la Poética de Luzán, yo demostré con numerosos documentos que la primera edición de esa todavía casi insuperable compilación de teorías poéticas clásicas sí influenció a los poetas, a partir de la propia generación del autor.

No busco polémicas. Pero pienso que sólo mediante la continua dialéctica entre dedicados investigadores de un mismo campo se llegará en éste a la verdad, la cual podrá coincidir con el modo de pensar de alguno de esos especialistas, o bien reflejar un matiz intermedio. Lo cierto es que ninguna de estas opciones interpretativas resultará convincente sin que se fundamente fielmente en documentos pertenecientes al mismo pasado del que se habla. Miremos, por tanto, sin más preámbulos ya, el primero de los dos esquemas antiguos para la periodización de la poesía a los que aludí más arriba. En el Panegírico por la poesía (1627), atribuido alguna vez al agustino sevillano 
Fernando de Vera y Mendoza, se divide la historia de la poesía en períodos - término que parece muy moderno-, los cuales abarcan desde la poesía de la antigüedad hasta la moderna de diversas naciones, pero el panegirista va ciñéndose cada vez más a la poesía castellana.

El período del Panegírico que nos interesa más es el decimotercio, cuyos límites temporales se extienden desde la poesía del marqués de Santillana ( $\mathrm{m}$. 1458) hasta el año 1621, pues el libro que comentamos se había terminado de escribir seis años antes de su primera impresión. Es decir, unos ciento sesenta. años, que incluyen el primer Renacimiento y el Renacimiento o primer Siglo de Oro. Esta demarcación es en sí muy significativa, según veremos más tarde. Sin embargo, en el Panegírico, que su autor escribió a los diecisiete años, los marcadores cronológicos implícitos son todavía más iluminativos. No hay figura histórica que el panegirista mencione con mayor frecuencia que el emperador Carlos V, y en estas menciones se inclina a acoplar el nombre del gran monarca con el del poeta a quien éste admiraba más: el toledano, Garcilaso de la Vega. A los poetas de su período decimotercio el cronologista los llama "clásicos" (Panegírico [1627] 1886, fol. 53), la primera ocasión en que en cualquier idioma moderno se llama así a literatos que han hecho versos en su lengua vulgar, según he hecho ver en otras publicaciones (por ejemplo, Sebold, 1982, págs. 322-323; y Sebold, 1985, págs. 42-43). La repetida mención del emperador Carlos V, junto con Garcilaso, revela que para el autor del Panegírico por la poesía el momento cumbre del período clásico que define, es la primera mitad del siglo XVI.

En las mismas páginas el panegirista vuelve a definir su concepto de lo clásico tomando nota de "los que mejor imitan a Garcilaso" (Panegírico [1627] 1886, fol. 51). Ahora bien: imitar a un "clásico" —y Garcilaso estaba ya definido como tal - es renovarlo, y renovar lo clásico no es otra cosa sino ser neo-clásico. En todos los diccionarios la posición del Neoclasicismo respecto del clasicismo está descrita con voces como restauración, renacimiento, retorno, renovación. Y en el verbo imitar, tal como se usa en el Panegírico, está implícita la idea del retorno. La imitación o emulación ponía al poeta en diálogo con un buen modelo, que le brindaba la ciencia poética de un pasado mejor. "Revolved, pues, vosotros, oh Pisones, decía Horacio, / las obras de los griegos noche y día" (Iriarte, trad. 1805, pág. 37). He aquí que los romanos respecto de los griegos eran ya hace dos mil años neoclásicos; y a partir de 1627 existía un punto de referencia en el tiempo para la definición del clasicismo nacional español- la época de Garcilaso-, así como alguna noción sobre cómo había que situarse ante el clásico Garcilaso para ser neoclásico. Para reconfirmar todo esto miremos la teoría del autor del Panegírico relativa a la tonalidad estilística de la lírica clásica y así neoclásica también. 
En lo que dice el joven panegirista sobre el estilo que debe caracterizar a la lírica clásica, se nos presentará una elocuente demostración del estrecho parentesco entre el Renacimiento y la Ilustración en lo que se refiere a la ideología poética. Dice el autor del libro de 1627: "Ninguno puede ser poeta, aunque haya quien lo semeje, faltándole la divinidad y dulzura, tan necesaria en los versos" (Panegírico [1627] 1886, fol. 9; la cursiva es mía). Como es sabido, a los grandes poetas se les atribuía cierta clase de "divinidad", porque se consideraba que su visión del mundo estaba inspirada por los dioses. Pero la voz que me interesa es el otro substantivo usado en el trozo que acabamos de leer: dulzura. Se trata de un término técnico en la crítica clásica y neoclásica. Se refiere a la capacidad del estilo para suscitar una delicada reacción emocional en el lector; y el término volverá a aparecer en la Poética de Luzán, donde se le dedican tres capítulos: "Del deleite poético y de sus dos principios: belleza y dulzura", "De la dulzura poética", y "Reglas para la dulzura poética dilucidadas con varios ejemplos" (Luzán, 1977, págs. 203-217). Fuera del hecho de que Garcilaso está citado como ejemplo en los capítulos luzanescos sobre la dulzura poética, ¿cómo se compagina todo esto con la tradición garcilasista?

Para responder a esta interrogación hace falta recordar que entre los poetas y críticos de las épocas clásica y neoclásica el término dulzura tiene un sinónimo relativamente frecuente. Quiero decir el substantivo blandura y su correspondiente forma adjetival blando. En su canción V, "La flor de Gnido", Garcilaso habla en tercera persona de sí mismo y de su inspiración, y encontramos la frase: "su blanda musa" (Garcilaso, 1964, pág. 47). En 1627 el panegirista alude por tanto a un rasgo garcilasiano al insistir en la necesidad de la dulzura en la lírica. En pleno Neoclasicismo dieciochesco, Cadalso, que ha leído la poesía de Garcilaso y la Poética de Luzán, llamará a su inspiración "mi blando numen" (Poetas líricos del siglo XVIII, 1952-1953, t. I, pág. 249a), haciendo, claro está, deliberado eco a las palabras de Garcilaso. Ahora bien: la reacción de Cadalso ante el precepto de la dulzura y el ejemplo de Garcilaso nos ayudarán a detectar otros casos de actividad poética neoclásica ya en el primer Siglo de Oro.

Pues las palabras del panegirista sobre la dulzura lírica ya citadas se hallan en sus prolegómenos; y fiel a sus principios críticos, al ir juzgando uno tras otro "a los que mejor imitan a Garcilaso", les va sometiendo a una prueba de dulzura. Y resulta que uno es "afectuoso", y otro es "muy dulce y enamorado"; uno tiene "sentidísimos versos", mientras que otros dos se caracterizan por el "afecto y dulzura"; y por fin, uno que domina la preceptiva poética a la vez que ha logrado el deseado tono afectivo, nos brinda "versos científicos y dulces", etc. (Panegírico [1627]1886, fols. 50-55). Estos poetas del siglo XVI encuentran en el verso de Garcilaso el mismísimo estímulo que encontraría en él Cadalso dos siglos más tarde. El hecho de que los poetas del quinientos 
analizados en el Panegírico por la poesía, de 1627, emulen el tono afectivo del verso de Garcilaso, es una nueva y muy clara ilustración de que con respecto a los clásicos nacionales el fenómeno neoclásico se da por vez primera en el propio Siglo de Oro.

Decíamos al comienzo que la literatura se desenvuelve por grandes tendencias, y ahora se trata concretamente de la que yo llamo tendencia neoclásica, cuyo comienzo por razones ya evidentes puede fecharse hacia 1540. Garcilaso muere en 1536, y antes de su propio óbito en 1542 Boscán lamenta la pérdida de su compañera y del mejor tiempo para la poesía castellana. Pues había desaparecido, dice, “... aquel que nuestro tiempo trujo ufano, / el nuestro Garcilaso de la Vega" (Boscán, 1964, pág. 221); y según Boscán, no se volvería a subir a esa cumbre sin buscar modelo en el toledano, que no "solamente en mi opinión, mas en la de todo el mundo ha sido tenido por regla cierta" (en Porqueras Mayo, 1965, pág. 211). En el uso metonímico de la palabra regla por la obra de Garcilaso tenemos un nuevo anticipo de la visión neoclásica dieciochesca; pues cuando Cadalso regala a su amigo Meléndez Valdés unos versos originales y un ejemplar de la poesía de Garcilaso, le dice que le manda "con prendas de mi amor reglas del arte".

La larga tendencia neoclásica se prolongará, al lado de otras tendencias como la barroca y la romántica, hasta la muerte de Bécquer aproximadamente. Pero dentro de la tendencia neoclásica se encuadrará el movimiento neoclásico, y el segundo ensayo antiguo de periodización nos servirá para fechar ya el inicio del movimiento. En 1754, año de la muerte de Luzán, el malagueño Luis José Velázquez, marqués de Valdeflores (1722-1772), publica su importante obra crítica Orígenes de la poesía castellana. Junto con Luzán, el P. Sarmiento y D. Gregorio Mayans y Siscar, el marqués de Valdeflores es uno de los cuatro españoles que conocen mejor entonces la historia de la poesía nacional. Según su contemporáneo Agustín de Montiano, el autor de los Orígenes ha "abierto la senda a los que quisieren ilustrar esta parte de la historia literaria poco conocida, o enteramente abandonada hasta aquí' (Censura, en Velázquez, 1797², págs. 5-6), y Velázquez conoce asimismo a los más importantes poetas españoles de su propio tiempo por haber sido contertulio de ellos en la Academia del Buen Gusto (1749-1751).

Velázquez periodiza la poesía castellana en cuatro edades que preceden a un "estado actual de la poesía castellana", o sea un apartado sobre la época durante la que él mismo escribe. Además de la época de Velázquez, nos interesan las edades tercera y cuarta. El marqués no coincide completamente con el panegirista en la delimitación de aquel buen siglo clásico que brindaría modelos a los neoclásicos de centurias posteriores; pues no se remonta al marqués de Santillana, pero sí dice que en Juan del Encina "la buena poesía daba 
ya muestras de querer manifestar su vigor" (Velázquez, 1754, pág. 55; la cursiva es mía), esto es, que encuentra ya atisbos de renovación en el siglo que hoy llamamos el primer Renacimiento. Velázquez inicia sus reflexiones sobre la tercera edad de la poesía castellana en esta forma: "El restablecimiento de las letras en España a principios del siglo decimosexto hizo a la poesía castellana variar de semblante por los mismos medios que entre nosotros le mudaron entonces todas las demás artes y ciencias" (ibíd., pág. 57), quiere decirse, según explica a continuación, por la influencia italiana. A lo largo de su capítulo sobre la tercera edad poética el marqués señala en modelos selectos lo que él considera como ejemplos de la buena poesía, utilizando siempre este adjetivo modesto con la mayor sobriedad clásica, en lugar de un superlativo. Por ejemplo, sobre la égloga escribe: "Esta especie de poesía nació entre nosotros en el buen siglo, la debemos a Boscán, Garcilaso y D. Diego de Mendoza, que fueron los primeros que empezaron a usarla con arte" (ibid., pág. 131). De éstos desde luego ocupa el primer término "Garcilaso de la Vega, que, al decir de Velázquez, con razón es tenido por el Príncipe de la Poesía Castellana" (ibíd., pág. 59).

En el mismo capítulo de Velázquez aparecen mencionados como modelos recomendables para la imitación otros poetas clásicos que efectivamente serían imitados después por muchos poetas neoclásicos: Fernando de Herrera, los Argensolas, Esteban Manuel de Villegas, Alonso de Ercilla, el bachiller Francisco de la Torre, etc. Pero la figura que casi llega a rivalizar con Garcilaso, es fray Luis de León, "a quien, dice Velázquez, no sólo nuestra lengua, sino también nuestra poesía debe en gran parte la altura, a que llegó en esta edad" (ibíd., pág. 64), es decir, en la tercera de las edades poéticas que se definen en el libro. Leamos entero el párrafo final del capítulo que comentamos ahora, porque el nombre que Velázquez da al siglo XVI es entonces nuevo, y porque son importantes sus conclusiones sobre cómo los poetas españoles de aquella época llegaron a ser ellos mismos clásicos:

Esta tercera edad fue el Siglo de Oro de la poesía castellana; siglo, en que no podía dejar de florecer la buena poesía, al paso que habían llegado a su aumento las demás buenas letras. Los medios sólidos de que la nación se había valido para alcanzar este buen gusto no podían dejar de producir tan ventajosas consecuencias. Se leían, se imitaban, y se traducían los mejores originales de los griegos y latinos; y los grandes maestros del arte [poética] lo eran asimismo de toda la nación. (ibid., págs. 66-67; las cursivas son mías)

A la vista de estas líneas de 1754 recuérdese el ya mencionado uso del adjetivo clásico para describir a poetas nacionales en el Panegírico por la poesía, de 1627, y adelantémonos un momento en el tiempo para considerar lo que José Nicolás de Azara diría sobre Garcilaso en su Prólogo a la histórica 
edición del Príncipe de los Poetas Castellanos, de 1765: "El poeta que no haya imitado a los antiguos, no será imitado de nadie [...]. Garcilaso se hizo poeta estudiando la docta antiguiedad [...] y éste es el modelo que presento a mis paisanos" (Garcilaso, 1765, pág. 14, sin numerar). Reunidas estas tres referencias, queda claro cuándo empieza el fenómeno neoclásico, cómo va desarrollándose, y cómo da unidad a la historia poética a través de muy diversas épocas. Se desprende asimismo de esta confrontación que ser neoclásico en España es imitar, ya a los clásicos grecolatinos, ya a los clásicos nacionales.

De tanta importancia para el movimiento poético del setecientos es la poesía del quinientos, que el marqués de Valdeflores tiende a ver toda su centuria como una reencarnación del Renacimiento. Mas primero veamos cómo el marqués cierra sus consideraciones sobre la tercera edad o Siglo de Oro de la poesía castellana, porque para la crítica dieciochesca no hay sino un solo siglo áureo. "La poesía, que hasta entonces había seguido entre nosotros los pasos de las demás artes y ciencias, explica, empezó con ellas a decaer a la entrada del siglo decimoséptimo; contribuyendo a ello con su mal ejemplo los italianos, de quienes la habíamos aprendido" (Velázquez, 1754, pág. 67). Alude al marinismo, o sea lo que acostumbramos llamar el barroco; y hablar de esta "revolución", al mismo tiempo que de los buenos poetas castellanos, dice, "sería ofender en cierto modo a un siglo tan instruido como en el que vivimos" (ibíd., pág. 71).

Quedan claros ya los conceptos de clásico, de anticlásico, de neoclásico y de modelo que eran determinantes para Velázquez, pero ¿hacia qué fecha empieza todo esto a tomar la forma coherente de movimiento? El apartado del marqués sobre el estado de la poesía en su propio tiempo comienza de modo muy significativo:

Después de la entrada de este siglo, en que las letras han tomado entre nosotros otro nuevo semblante, la poesía castellana va volviendo a recobrar su antigua majestad y decoro [...] Dio principio a esta gran reforma D. Ignacio [de] Luzán, publicando su Poética en el año 1737. (Velázquez, 1754, pág. 73; las cursivas son mías).

Recordemos ahora los términos con que Velázquez introducía sus observaciones sobre la poesía del quinientos: "El restablecimiento de las letras en España a principios del siglo decimosexto hizo a la poesía castellana variar de semblante". Así, tanto en el siglo de la Ilustración como en el Renacimiento la poesía se caracteriza por un nuevo "semblante"; y si en un caso tenemos un "restablecimiento", en el otro tenemos una "reforma" cuya finalidad es "recobrar" excelencias perdidas. En poesía, en fin, a partir de 1737 el siglo XVIII aspira a repetir el siglo XVI, aquel siglo de buena poesía, aquel siglo más clásico; y esto si no es neoclásico, ¿cómo se ha de llamar? 
En el Prólogo a mi edición de la Poética de Luzán he demostrado que todo el siglo XVIII abrazó la opinión de Velázquez de que el crítico zaragozano fue el reformador de la poesía por antonomasia (véase "La influencia de Luzán sobre los neoclásicos", en Luzán, 1977, págs. 55-64). Examinemos ahora algunas opiniones confirmatorias del siglo XIX, no consideradas en el aludido prólogo. En 1807, Quintana escribe: "[la poesía castellana] volvió a renacer hacia la mitad del siglo pasado, por los laudables esfuerzos de algunos literatos [...]. La principal gloria de esta revolución feliz se debe a D. Ignacio de Luzán, que no contento con señalar la senda del buen gusto en su Poética, publicada en 1737, dio también el ejemplo de marchar por ella con los buenos rasgos poéticos que se leen en las pocas composiciones que de él se han publicado" (Quintana, 1807, t. I, pág. LXXXIV; la cursiva es mía). En 1813, en su obra De la Littérature du Midi de l'Europe, el crítico suizo Simonde de Sismondi juzga así la Poética luzanesca: "Esta obra, escrita con mucho juicio y vasta erudición, clara sin languidez, elegante sin afectación, fue recibida por los literatos como una obra maestra, y desde entonces [1737] ha sido citada en España por el partido clásico como fuente de las reglas del gusto verdadero" (Sismondi, 1853, t. II, pág. 428). En 1827, en los apéndices a su propia Poética, Martínez de la Rosa apunta esta opinión: En cuanto al "restablecimiento de las letras", dice, "reservada estaba tan ardua empresa para mediados del siglo precedente, habiéndola acometido con igual audacia que tino el sensato Luzán, que puede considerarse como principal restaurador de la poesía" (Martínez de la Rosa, $1834^{2}$, pág. 91). Todavía en 1872 Manuel de la Revilla y Pedro de Alcántara García expresan el mismo juicio, pues ven en la Poética de Luzán una "obra de una trascendencia grande para nuestra regeneración literaria" (Revilla, 1872, t. II, pág. 494). Vuelve a aparecer en estos pasajes un término ya familiar, restablecimiento, y otros dos nuevos, renacer y regeneración, que igual que el grupo de voces semejantes que destacamos más arriba vienen a ser en la práctica sinónimos de Neoclasicismo, neoclásico.

No deja de haber, empero, en el decenio de 1720 importantes anticipos de la magna empresa luzanesca. En el tomo I del Diccionario de Autoridades, de 1726, se hallan consultados en forma sistemática como fuentes léxicas versos de Garcilaso, Boscán, fray Luis de León, los Argensolas, Villegas, etc.; y ésta yo la considero una decidida voluntad neoclásica, al menos en lo que afecta a la lengua. En el mismo año de 1726 sale asimismo el tomo I del Teatro crítico universal del P. Feijoo, y en esas páginas los mismos poetas son repetidamente elogiados: "En los asuntos poéticos, ninguno hay que las musas no hayan cantado con alta melodía en la lengua castellana" (Feijoo, 1952, pág. 47). Y algunos años más tarde, mientras Luzán preparaba esa segunda edición de la Poética que su muerte no le permitiría ver en letras de molde, se proponían también otros muy serios proyectos de publicación de índole innegablemente 
neoclásica. En sus Memorias para la historia de la poesía y poetas españoles (escritas en 1745), el P. Sarmiento exclama: "¡Ojalá hubiese algún mecenas que se determinase a costear la impresión de todas las poesías de Berceo!". Espera lo mismo para Pero López de Ayala y otros clásicos españoles de la Edad Media, y es a la par muy significativa la siguiente observación del benedictino: "Sería una cosa curiosa que se buscasen en los archivos aquellas composiciones poéticas que han merecido el premio de la joya en España, cuando se ejercitaban en la gaya los poetas españoles y que se diesen a la luz pública" (Sarmiento, 1942, págs. 187, 243). Varios años más tarde Velázquez y sus contertulianos de la Academia del Buen Gusto proponían una obra antológica semejante pero de todavía mayor alcance cronológico: se había de titular Colección de las poesías castellanas selectas desde el origen de nuestra poesía hasta el tiempo presente. Velázquez llama la atención sobre "las grandes ventajas [...] que sin duda conseguirá el público en tener un cuerpo de nuestras mejores poesías que en adelante pueda servir de modelo para fijar el buen gusto de la nación en esta parte" (Velázquez, 1754, pág. 141).

Insiste Velázquez en la importancia del modelo. Ahora bien: ningún concepto es más fundamental para el Clasicismo y el Neoclasicismo. Desde la antigüedad se viene insistiendo en que de un buen modelo de poesía cabe deducir toda la preceptiva poética. ¿Y cómo se ha de llamar tal actitud sino neoclásica? Es más: este afán de los decenios de 1740 y 1750 , de rescatar a los grandes poetas castellanos del olvido es tal vez el dato individual más importante para ilustrar de modo inconcuso el hecho de que forman un solo movimiento neoclásico los poetas y críticos de esos años y los de 1760 en adelante. Pues, en los últimos cuarenta años del siglo lograrían por fin llevar a cabo esos proyectos antológicos Juan José López de Sedano, en los nueve tomos de su Parnaso español (1768-1778), y Tomás Antonio Sánchez, en su Colección de poesías castellanas anteriores al siglo XV (1779-1782). Sin embargo, la más elocuente manifestación editorial del brío neoclásico son las muy esmeradas reediciones de poetas individuales de aquel siglo que ya en 1627 se bautizó como "clásico": fray Luis de León en 1761, Garcilaso de la Vega en 1765, Esteban Manuel de Villegas en 1774, los Argensolas en 1786, etc. Todo esto significa que España estaba en pleno Neoclasicismo antes del año 1760, y aun antes del año 1750. No empieza, por consiguiente, dicho movimiento ni en 1780 ni en 1790 , como muy equivocadamente ha afirmado la crítica reciente. De todo lo anterior se infiere a la par otra consecuencia profundamente significativa: es imposible de toda imposibilidad que el Prerromanticismo o Romanticismo preceda en España al Neoclasicismo, como han querido creer los dos colegas citados al inicio de estas reflexiones. Pues nadie ha fechado antes de 1770 la aparición del fenómeno romántico, y en cambio, nosotros tenemos sobrados testimonios de que el movimiento neoclásico antecede a esa fecha en treinta o cuarenta años. 
Hablemos ya de la periodización del Romanticismo setecentista. Yo he acostumbrado fechar los comienzos de esta nueva tendencia por el estilo, la temática y sobre todo la cosmovisión de las obras del decenio de 1770 que enumeré antes. Mas consideremos a la vez varios comentarios críticos de la primera mitad del siglo XIX, en los cuales se alude claramente a ese decenio; y dejemos así una vez más que los testigos de época nos fechen las tendencias y los movimientos. Quintana concluye la ya citada Introducción de 1807 a su antología de Poesías selectas castellanas con unas reflexiones muy sugerentes sobre Cadalso. En primer lugar dice que es en Cadalso "en quien se terminan los ensayos y esfuerzos para restablecer el arte" (Quintana, 1807, t. I, pág. LXXXV), esto es, los esfuerzos iniciados por Luzán y su generación. Y en realidad tiene razón Quintana, porque empezando por el propio Cadalso casi no habrá ya poetas que sean exclusivamente neoclásicos, sino que todos alternarán en algún grado entre las dos modalidades, neoclásica y romántica.

¿Y en qué términos reconoce Quintana la aparición de la nueva alternativa poética nacida en el decenio de 1770? Dice: "Desde entonces empieza una nueva época en la poesía castellana, con otro fondo, otro carácter, otros principios, y aun puede decirse que con otros modelos" (ibid., pág. LXXXV). Martínez de la Rosa se une a Quintana en proclamar el principio de una nueva era poética hacia 1770, década en la que Meléndez Valdés compuso su inquietante oda "A la mañana en mi desamparo y orfandad":

...de tantos ingenios como han cultivado con gloria la lírica española después de Meléndez, dice Martínez de la Rosa, apenas habrá alguno que no se haya formado en su escuela. Así es que con razón puede señalársele para denotar una nueva era, demasiado cercana a nosotros para juzgarla con imparcialidad. (Martínez de la Rosa, $1834^{2}$, pág. 92)

El llamado ecléctico Martínez de la Rosa, ora neoclásico, ora romántico, era, en efecto, uno de los ingenios formados a la sombra del a veces más borrascoso que dulce Batilo.

Es igualmente interesante lo dicho por Quintana en su ensayo "Sobre la poesía castellana del siglo XVIII", impreso por última vez en vida en 1852 . Allí le concede a Cadalso "un lugar muy distinguido entre los restauradores de la poesía". Entre "todos los discípulos de aquella escuela fundada por Cadalso y tan ilustrada por Meléndez", el más aventajado es, a juicio de Quintana, Nicasio Alvarez de Cienfuegos. ¿Qué personalidad poética ve el autor de la oda "A la imprenta" en el autor de "La escuela del sepulcro"? Responde así a nuestra pregunta: "Aunque el fondo de ideas sobre que su imaginación se ejercita pueda decirse tomado de la filosofía francesa [Rousseau, por ejemplo], no ciertamente el tono ni el carácter, que guardan más semejanza con la poesía osiánica y con la poesía alemana". Sigue afirmando que "Meléndez, Jovellanos, 
Cienfuegos y sus imitadores habían introducido en la poesía española un gusto extraño, que parece tomado del francés, del alemán y del inglés" (Quintana, 1946, págs. 156b, 157a; la cursiva es mía). Efectivamente: se habían dado los primeros anticipos del Romanticismo en la poesía de lengua inglesa (Thomson) y en la de lengua alemana (Gessner) antes que en los demás países europeos, y esos poemas venían influyendo en España desde el tiempo de Cadalso. Curiosamente, los orígenes nacionales de los influjos extranjeros (francés, alemán, inglés) que Quintana identifica en el primer Romanticismo son los mismos de los que se hablaría después en relación con el segundo Romanticismo, quiero decir, el decimonónico.

De estas últimas líneas de Quintana, empero, lo más interesante es el término osiánico: En la polémica entre clásicos y románticos del primer decenio del siglo XIX esta voz funcionaba como sinónimo de romántico, pues los contrincantes distinguían entre "clásicos y osiánicos", o bien entre "los homéridas" y "los osiánicos" (Navas Ruiz, 1971, págs. 27, 42). Mas he aquí que Quintana encuentra osiánicos ya en el siglo XVIII, concretamente en la escuela fundada por Cadalso hacia $1770^{3}$. Tampoco habría que olvidar que en los últimos años se han aportado muchos datos nuevos sobre el término romántico y su antecedente dieciochesco romancesco, así como sobre sus diversos sentidos; y en romancesco tenemos otro marcador cronológico para la corroboración de nuestro esquema de periodización ${ }^{4}$. Se distingue a la vez el decenio final del siglo XVIII por la invención del primer término en cualquier idioma - - "fastidio universal" - para el dolor romántico, según he hecho ver en mi ensayo "Sobre el nombre español del dolor romántico" (Sebold, $1989^{2}$, págs. 157-169).

Para concluir, procuraré reducir las fechas más significativas que hemos mencionado a un esquema, extendiendo éste hasta el siglo XIX, del que, sin embargo, no me proponía hablar en detalle en esta ocasión; y al mismo tiempo aludiré a un problema de cronología literaria que afecta tanto al Neoclasicismo como al Romanticismo, especialmente en los últimos años del siglo XVIIl y los primeros del XIX. Todas las fechas que voy a indicar son aproximadas; porque en la historia literaria las muy concretas se exponen a toda suerte de errores. Entre 1540 y 1870 se da una notable tendencia neoclásica. En esta tendencia se encuadra el movimiento neoclásico cuya influencia se extiende entre 1740 y 1840. Merced a la interacción entre el Neoclasicismo y la filosofía de la Ilustración -proceso que he historiado en otras ocasiones- el Romanticismo emerge hacia 1770 y se prolonga bajo diferentes variantes hasta 1870 . Veo

3. Sobre lo osiánico en los poemas de esta escuela, véase Montiel, 1974, especialmente págs. $74-80$.

4. Para ejemplos de romancesco, véase mi artículo "Lo romancesco, la novela y el teatro romántico" en Sebold, 1983, págs. 137-163. 
cierta comodidad en subdividir el Romanticismo en la forma siguiente. Primer Romanticismo: 1770-1800. Actividad romántica subterránea durante el período de represión política de Carlos IV, José I y Fernando VII, 1800-1830. Segundo Romanticismo: 1830-1860. Posromanticismo: 1850-1870. Se dan entrecruzamientos entre unas tendencias y otras, los cuales representan las diversas opciones creativas disponibles al literato en cualquier momento histórico.

(Tal entrecruzamiento y pluralidad de opciones, que en nada respeta las casillas de la historia literaria al uso, es en efecto muchísimo más complejo de lo que pudiera parecer hablándose de un solo género literario, como lo hacemos nosotros aquí. Ello se vería muy claramente, por ejemplo, si se incluyera la novela y el realismo en nuestro esquema. Pues a partir del Fray Gerundio del P. Isla (1758) existen en la literatura española los procedimientos del realismo sistemático; hay mucho realismo en las novelas de Montengón, aparecidas en los decenios finales del setecientos (en algunas novelas de este escritor se mezclan Realismo y Romanticismo); y en la novela histórica romántica la representación del mundo y sus habitadores es asimismo de técnica rigurosamente realista, aunque el realismo no empieza a manifestarse como movimiento hasta la década de 1840).

El problema de cronología literaria al que aludía hace un momento es en realidad un problema de dos cronologías, que ya se armonizan, ya se oponen. Se trata de la cronología temporal y la cronología artística, y la distinción entre ellas servirá para iluminar tanto la alternancia de ciertos poetas entre la modalidad neoclásica y la romántica, como el indicado entrecruzamiento de esas dos tendencias y movimientos. Por la influencia de la filosofía sensacionista o sensista los neoclásicos de la Ilustración someten la bella naturaleza al examen por sus cinco sentidos, y a través de éstos llegan a ligarse psicológicamente con esa madre universal. Es al comienzo una tranquila y gozosa comunicación espiritual entre dos socios iguales, mas cuando el poeta deja de interesarse por cualquier cosa que no sea su propia situación penosa en el cosmos, esos sentidos suyos no serán ya medios de reposada comunicación anímica, sino que devendrán órganos de transferencia con los que el adolorido cantor podrá colorar y deformar el universo a su propia imagen, y nacerá en ese momento la visión egocéntrica panteísta romántica de la naturaleza. Sin embargo, porque los objetos de los sentidos, así como las actitudes humanas, están perpetuamente cambiando, el proceso sensorial que acabo de describir es reversible, y el poeta puede un día por halagüeñas circunstancias personales preferir su vieja y confortante visión neoclásica a la nueva borrascosa y romántica.

Ahora bien: el punto en el que quiero insistir es que en medio de este constante ir y venir entre las dos modalidades (que es típico de poetas como 
Cadalso, Meléndez Valdés, Jovellanos, Cienfuegos, José Joaquín de Mora y Francisco Martínez de la Rosa), la manera romántica será siempre posterior a la neoclásica, sean las que sean las fechas de dos composiciones que se comparen, esto es, si pensamos en la cronología artística; porque en un principio el estilo romántico fue el segundo de los dos en evolucionar y presentarse en la escena de la historia literaria, y la condición previa sine qua non de su aparición fue la liberalización de las actitudes clásicas y neoclásicas gracias a la epistemología observacional dieciochesca. Como consecuencia, un poema determinado puede ser temporalmente muy posterior a otro y sin embargo artísticamente muy anterior a éste. Pienso en la oda anacreóntica "A una fuente" de Meléndez Valdés, que es de 1814; pero es el primer ejemplo que analizo al explicar en mis clases la evolución filosófica y estilística de Batilo de la postura neoclásica a la romántica, porque es un ejemplo perfecto de la confiada afirmación neoclásica de la armonía que puede darse entre el alma humana y el alma natural.

En cambio, la oda XXIV de Meléndez, "A la mañana, en mi desamparo y orfandad" se escribe en 1777 , mas es artísiticamente muy posterior al ya mencionado poema de 1814; es, diría yo, artísticamente de la misma época que gran parte de la poesía de Espronceda. Existen también poemas de Meléndez: la oda anacreóntica XLIII, "De la noche" (1784), y el romance XXXIV, "La tarde" (1797), en los que vienen a coincidir hasta cierto punto la cronología de la evolución artística y la cronología de nuestra era cristiana ${ }^{5}$. La aparición del Romanticismo es posterior en el tiempo a la aparición del Neoclasicismo. Mas nunca nunca se puede suponer, como hacía la crítica en otra época, que todo poema romántico sea posterior en el tiempo a todo poema neoclásico. Hace falta estar constantemente sobre aviso, pues todavía Gustavo Adolfo Bécquer escribirá una alegre anacreóntica neoclásica a lo Batilo: “Toma la lira, toma / la de cuerdas doradas", etc. (Bécquer, $1969^{13}$, págs. 480-482). Pero de todas las discrepancias entre la cronología temporal y la cronología artística la mayor es la que concierne al célebre poema en prosa Noches lúgubres de Cadalso: por un lado, es en el tiempo la primera obra romántica plenamente lograda del Romanticismo setecentista; y por otro lado, puede decirse que artísticamente pertenece al ambiente del decenio 1830-1840. José Yxart veía en las Noches lúgubres las características del "Romanticismo melenudo [...] del 37" (Cadalso, 1885 , pág. VI); y en 1840 , en pleno Romanticismo decimonónico, el Semanario Pintoresco Español publicó una disquisición satírica sobre la naturaleza del Romanticismo titulada "Costumbres: los poetas y la melancolía", donde es notable el papel que hace la obra de Cadalso. Veamos el pasaje clave:

5. Las fechas de poemas individuales de Meléndez que menciono son las que se dan en la monumental edición de Polt y Demerson: Meléndez Valdés, 1981-1983. 
Jacobo Medina tenía un carácter [...] adusto. No iba jamás a sociedad alguna, ni recitaba otros versos que los elegíacos; leía las Noches lúgubres de Cadalso, y vestía siempre de luto, en verano y en invierno. Aficionado, como el búho, a las sombras de la noche, abominaba la luz del sol que lo distraía de sus profundas y melancólicas abstracciones. [...] El fín de Medina ha sido trágico y lamentable. [...] se degolló con una navaja de afeitar, los socorros no alcanzaron, y expiró como hábía vivido maldiciendo la sociedad, y renegando del mundo (Schurlknight, 1986, págs. 163-166).

A esto nada puede añadirse.

\section{BIBLIOGRAFÍA}

ARCE,Joaquín. 1981. La poesía del siglo ilustrado, Madrid, Alhambra.

BÉCQUER, Gustavo A. 1969,13ª . Obras completas, ed. de Dionisio GAMALLO FIERROS, Madrid, Aguilar.

BOSCÁN, Juan. 1964. Coplas, sonetos y otras poesías, ed. de Manuel de MONTOLÍU, Barcelona, Montaner y Simón.

CADALSO, José. 1885. Obras escogidas, ed. de José YXART, Barcelona, s. e.

CASO GONZÁLEZ, José Miguel. (en colaboración con Joaquín ARCE y Juan Antonio GAY A NUÑO. 1970. Los conceptos de Rococó, Neoclasicismo y Prerromanticismo en la literatura española del siglo XVIII (Cuadernos de la Cátedra Feijoo, núm. 22), Oviedo, Universidad de Oviedo, 71 págs.

—. 1980. "Notas sobre la periodización de la literatura española en la segunda mitad del siglo XVIII", Actas del Sexto Congreso Internacional de Hispanistas, Department of Spanish and Portuguese, University of Toronto, págs. 169-171.

—. 1983. "El problema de la periodización", en Historia y crítica de la literatura española, t. IV, "Ilustración y neoclasicismo", Barcelona, Crítica, págs. 13-19.

FEIJOO Y MONTENEGRO, Benito Jerónimo. 1952. Obras escogidas, ed. de Vicente de LA FUENTE (Biblioteca de Autores Españoles, t. LVI), Madrid, Atlas.

GARCILASO DE LA VEGA, 1765. Obras de-, ilustradas con notas [de José Nicolás de AZARA], Madrid, en la Imprenta Real de la Gaceta.

- 1964. Obras completas, ed. de Elías L. RIVERS, Columbus, Ohio, Ohio State University Press.

IRIARTE, Tomás de, trad. 1805. Arte poética de Horacio [1777], en Colección de obras cn verso y prosa, Madrid, Imprenta Real, t. IV, págs. I-LXV, 1-124.

LUZÁN, Ignacio de. 1977. La Poética o reglas de la poesía en general, y de sus principales especies [1737, 1789], ed. de Russell P. SEBOLD (Textos Hispánicos Modernos, 34), Barcelona, Labor.

MARTÍNEZ DE LA ROSA, Francisco. $1834^{2}$. Poética española [1727], París, Imprenta de Julio Didot. 
MELÉNDEZ VALDÉS, Juan. 1981-1983. Obras en verso, ed. de Juan H. R. POLT y Jorge DEMERSON (Colección de Autores deI Siglo XVIII, núm. 28, I-II), Oviedo, Cátedra Feijoo.

MONTIEL, Isidoro. 1974. Ossián en España, Barcelona, Planeta.

NAVAS RUIZ, Ricardo, ed. 1971. El Romanticismo español. Documentos (Biblioteca Anaya, núm. 96), Salamanca, Anaya.

Panegírico por la poesía [1627]. 1886. Sevilla. Reimpreso en la Oficina de D. Enrico Rasco Sanromán, a expensas del Excmo. Sr. D. Manuel Pérez de Guzmán.

PEERS, E. Allison, ed. 1923. The Poems of Manuel de Cabanyes, Manchester, University Press.

Poetas líricos del siglo XVIII. 1952-1953. Ed. de Leopoldo Augusto de CUETO (Biblioteca de Autores Españoles, tt. LXI, LXIII, LXVII), Madrid, Atlas.

PORQUERAS MAYO, Alberto. 1965. El Prólogo en el Renacimiento español (Anejos de la Revista de Literatura, 24), Madrid, C.S.I.C.

- 1968. El prólogo en el manierismo y barroco españoles (Anejos de la Revista de Literatura, 27), Madrid, C.S.I.C.

QUINTANA, Manuel José, ed. 1807. Poesías selectas castellanas, desde el tiempo de Juan de Mena hasta nuestros días, Madrid, por Gómez Fuentenebro y Compañía, 3 vols.

-. 1946. "Sobre la poesía castellana del siglo XVIII", en Obras completas (Biblioteca de Autores Españoles, t. XIX), Madrid, Atlas.

REVILLA, Manuel de la y Pedro de ALCÁNTARA GARCÍA. 1872. Principios de literatura general e historia de la literatura española, Madrid, Tip. del Colegio Nacional de Sordomudos y de Ciegos, 2 vols.

SARMIENTO, fray Martín. 1942. Memorias para la historia de la poesía y poetas españoles [1745, 1775] (Colección Hórreo), Buenos Aires, Emecé Editores.

SCHURLKNIGHT, Donald E. 1986. "Another Document in Support of Cadalso's Romanticism", Romance Notes, t. XXVII, págs. 163-166.

SEBOLD, Russell P. 1982. "Sobre la lírica y su periodización durante la Ilustración (artículo-reseña sobre ARCE, La poesía del siglo ilustrado), Hispanic Review, t. L, págs. 297-326.

-. 1983. Trayectoria del Romanticismo español. Desde la llustración hasta Bécquer (Filología, núm 10), Barcelona, Crítica.

-. 1984. "Manuel de Cabanyes: lírico romántico en la encrucijada", Revista Canadiense de Estudios Hispánicos, t. VIII, págs. 351-380.

--. 1985. Descubrimiento y fronteras del Neoclasicismo español, Madrid, Fundación Juan March / Cátedra.

-.- $1989^{2}$. El rapto de la mente. Poética y poesía dieciochescas, Barcelona, Anthropos.

SIMONDE DE SISMONDI, J.C.L. 1853. Historical View of the Literature of the South of Europe [edición original en francés, 1813], trad. inglesa de Thomas Roscoe, Londres, Henry G. Bohn, 2 vols. 
VELÁZQUEZ, Luis José. 1754. Orígenes de la poesía castellana, Málaga, en la Oficina de Francisco Martínez de Aguilar.

-. 1797². Orígenes de la poesía castellana, Málaga, por los Herederos de D. Francisco Martínez de Aguilar. 


\title{
MI ENTIERRO DE CLARÍN: UN CUENTO RARO
}

\author{
Pedro Pablo VIÑUALES \\ Universidad Complutense
}

No pretendo con el presente artículo señalar, como hiciera Gramberg respecto de los paliques, un olvido ni un menosprecio por parte de la crítica hacia este relato. No cabe duda de que Mi entierro, firmado en Zaragoza en 1882 y publicado en La Ilustración Artística el 26 de marzo de 1893, es una nota disonante y atractiva dentro de la sinfonía realista que suponemos al hablar de la obra de Leopoldo Alas. No obstante, si lo asociáramos a otros dos cuentos como son Avecilla y Amor' è furbo de ese mismo año, reuniríamos una trilogía peculiar en la que "parece dominar el acento frívolo" (Ramos-Gascón, 1984 , pág. 77)1. Se ha comentado, por supuesto, el contraste que supone esta zona de su creación. Porque si el 16 de marzo de 1882 Clarín apuntaba en La Diana que el arte debía dejar de ser vago soñar, tres meses después escribe en el mismo diario cómo en el arte intervienen "el sentimiento y otros modos de conocimiento que el mero pensar racional” (cit. Lissorgues, 1989a, I, pág. 46).

Disponemos además de antecedentes como El doctor Pértinax o como La mosca sabia, escritos poco antes, y en los que, tanto el estilo como el tema, se alejan bastante de ese positivismo literario preconizado por el Naturalismo. Así, rastreando este género de relatos, nos remontamos al primerizo Juan Ruiz, donde el joven Leopoldo confesaba el proyecto de dar salida a una serie de narraciones extraídas de un librito original titulado Cuentos raros que pronto estará a la venta. Siendo encabezada por El Caramelo la idea no tuvo continuación, e, independientemente de que estuviera concluida o no, cabe considerarla como síntoma de un impulso inquieto y renovador (vid. Alas, 1985, pág. 100).

1. Estas palabras se refieren, concretamente, a Amor' è furbo; yo las hago extensibles a cualquiera de los tres relatos. En lo referente a Mi entierro, todas las citas llevarán la paginación correspondiente a esta edición de Cátedra que prologa Ramos-Gascón. 
Con la intención de asumir que Mi entierro es, al cabo, hijo de su tiempo, lo cual no es óbice para resaltar su modernidad, se le ha relacionado con los cuentos de Galdós, cargados de imaginería romántica, con las Narraciones Inverosímiles de Alarcón ${ }^{2}$, y hasta con Poe. Me ha llamado la atención, por otra parte, que se mencione cada vez más este relato, desde Gramberg (1958) hasta las últimas antologías, la de Richmond (1983) o de Lissorgues (1989b). Sin embargo, tal vez su calidad de experimento narrativo, ha desconcertado a todos los que han intentado clasificarlo.

"También en algún caso de la parte narrativa de su obra vence la fuerza narrativa a la preocupación por un contenido moral", comenta E. Gramberg, para concluir: "El resultado es, entonces, la farsa, de la cual hay bastante en Cuento futuro, Mi entierro y en ciertos episodios de Apolo en Pafos (1958, pág. 189). Laura de los Ríos, por su parte, lo incluye en la categoría de los grotescos, y lo relaciona con el expresionismo alemán. Del diálogo con el sereno, concretamente, opina que se trata de "una de las páginas cómicas más originales de Alas (...), de una modernidad muy cercana a nuestros días y al humor de un Gómez de la Serna o de algunos cuentos de Isak Dinesen" (1965, pág. 288); y señala cómo el final resulta "realmente desconcertante, no exento de un vago simbolismo, enlaza los planos de vida, sueño y muerte" (ibid., pág. 290).

Otra clasificación establecen para este cuento Ramos-Gascón e Y. Lissorgues. E1 primero destaca "de esta fantástica historia [...] su calidad de inverosímil" (1984, pág. 79). Las fuentes a las que acude seguidamente, sin llegar hasta las Danzas de la Muerte o a Los sueños de Quevedo, hacen bascular el tratamiento del tema ya hacia lo extraño, ya hacia lo maravilloso, empleando la terminología de Todorov (1970). Por otro lado, el Muérete y verás de Bretón de los Herreros, a que alude, se relaciona con la tradición, como señala G. Sobejano, y es asociable a otros ejemplos de paremiología popular. El dicho puesto en boca del sereno por el autor: "Muerto el perro..." (pág. 168), en su contexto bien pudiera ser complementado con aquel otro: "El muerto al hoyo..." Con todo, este tipo de fuentes poco explican la forma en que Clarín trabajó este relato, sirviendo sólo de referencias muy fragmentarias. Regresando al hilo de mi exposición puedo resumir que tanto Ramos-Gascón como Y. Lissorgues consideran éste un relato fantástico, mientras que G. Sobejano se refiere a él como maravilloso (1985, pág. 84).

Más ecléctica, C. Richmond afirma que se trata de "uno de los cuentos más imaginativos de Clarín. Con una ironía juguetona, se le ofrece al lector - cuya participación es, en este caso, esencial - una riqueza de posibilidades

2. Sabemos que escuchaba complacido sus rarísimos sucesos durante la infancia, según declara en El niño de la bola, de Solos de Clarín (1971, pág. 213). 
interpretativas, y encuentra sus raíces, no tanto en la fantasía de la sinrazón como en aquella locura de la razón que es la borrachera" (1983, pág. 337). Pienso que con esto se está refiriendo al mecanismo de lo imaginario en el proceso creativo, no a la realidad del narrador, el cual — como advirtió la propia Richmond- ofrece una lectura plurívoca.

Por último, R. Eberenz, resaltando lo singular de cada obrita como experiencia individual, describe este cuento como "una imbricación de lo real con lo fantástico y del humor negro” (1989, pág. 29), atribuyendo las vivencias progresivamente fantásticas a la demencia del personaje-narrador, y concluye tildándolo de fantasia macabra (ibíd, pág. 111 y 168).

Trataré de revisar en breve las diversas lecturas ofrecidas por el cuento, revisando las voces que configuran el discurso del narrador.

Desde el principio nos instalamos en un discurso autodiegético, con todo lo que ello implica de necesaria complicidad con el lector. Pero muy pronto el plano de lo cognoscible se aleja y debemos dejarnos conducir por la subjetividad que gobierna "aquella humedad en los pies podía volverme loco, por ejemplo" (pág. 617); la relación causa-efecto se nos ha hecho extraña. De aquí, no obstante, dimanará la lógica de las progresivas alucinaciones, en coherencia con la previamente manifiesta afición ajedrecística. La identificación real de los personajes, (policías, sereno, criado...) se superpone a las imágenes de esta obsesión dando lugar a una doble visión.

Tras la primera clave ofrecida por el narrador, la de su propia locura, un personaje plantea otra: "dicen si ha muerto de una borrachera" (pág. 168), y poco después Perico apunta una tercera: "de un ataque cerebral". De seguido, el fenómeno fantástico del desdoblamiento, introducido ya con el error de identificar al personaje-narrador con el que viene a amortajar, es tratado de modo antifantástico, es decir, con la plena aquiescencia del afectado. Ello aumenta el estupor de quien lee, su distanciamiento. Y el episodio que sigue acentúa esta lógica onírica retomando, como un leit motiv, la humedad en los pies.

Predispuestos por esta perspectiva inverosímil, el narrador pasa a ofrecernos las descripciones de los personajes que siguen, la mujer y el amante, los del partido, ya sin distorsión irracional alguna; incluso focaliza el discurso, como si de una narración realista se tratara, en la figura de D. Mateo Gómez, reproduciendo fielmente, en estilo directo, varias conversaciones en torno, y siendo capaz incluso de corregir a este personaje como narrador delegado: "D. Mateo dudaba si caracteres era esdrújulo" (pág. 174), o "nunca había sabido don Mateo si se dice así alas o aras" (pág. 175), mostrando una omnisciencia completa.

Cuando ya parece que la normalidad es estable, nuevamente interrumpe el narrador: "... mártir de la idea (de la humedad, señor mío, de la humedad", 
(págs. 175-6). En este punto del relato, de tensión apenas manifiesta, un nuevo cambio nos sorprende: “iMientes! - grité saltando de la caja. Pero no había nadie" (pág. 176), conduciéndonos de improviso a la extrañeza primera con un final que, ya sin resolución, recoge la repetida idea de la humedad y las imágenes ajedrecísticas. El cuento queda de este modo cerrado, sin posible interpretación más allá de él mismo, y el lector, que al entrar a una historia contada en pasado, podía haber intuido que se estaba recuperando una anécdota pasajera, queda absolutamente desconcertado. Por eso su asentimiento es aquí fundamental, como si se tratara de la lectura de un poema. Al coincidir la visión que actúa con la que narra, no extraemos una verificación epistemológica que pueda sustraernos del subjetivismo motriz. Pero esto, que de ordinario no supone más que la cesión de crédito, se trueca, en estas circunstancias, con la irrupción del absurdo, en una condición sine qua non. La asociación ridícula de volverse loco a causa de tener los pies mojados es, no obstante, verosímil en el plano de los personajes; así, Perico comenta las palabras de Clemente Cerrojos a la adúltera: "Tu marido se quita de enmedio el mejor día reventando de bestia y por mojarse los pies después de calentarse los cuernos" (pág. 618). Además habíamos leído, como anticipé:... volverme loco, por ejemplo, lo cual acentúa el carácter familiar que el fenómeno, como algo ya conocido, parece tener para el protagonista, cuyo campo de lo verosímil es diferentes al nuestro. Esa relatividad, ya que no asombro, al personaje le produce cierto fastidio, expresado de continuo con un Por de pronto... De este modo parece que el sujeto es testigo paciente de su propio cambio en el ámbito de lo gnoseológico. La confusión aumenta, porque vemos que el narrador juega con los planos real e imaginario, contrastándolos y poniendo sobre aviso de la progresiva distorsión, y siendo capaz de interpretar la psicología de los otros personajes y no la propia. Así, por ejemplo, reconoce por la voz que Perico, su criado, acababa de despertarse, pero no se cuestiona, ni aclara al lector, sobre su estado propio.

Desde que confunde a los policías con las torres negras, cualquier elemento actante puede ser enfocado bajo esta obsesión de ajedrecista. La dualidad que con ésta se abre nos puede hacer deducir que se trata, en todo caso, de una locura temporal, la cual es corregida desde un presente narrativo; es decir, que el narrador racionaliza la visión alucinada del personaje -él mismo en el pasado.

Acudiendo ahora a las digresiones de otro personaje-narrador, el de El Horla de Maupassant, acerca de su locura, leemos: "He conocido algunos que seguían siendo inteligentes, lúcidos y sagaces en todas las cosas de la vida menos en un punto. Hablaban de todo con claridad, facilidad y profundida, pero de pronto su pensamiento chocaba contra el escollo de la locura y se hacía pedazos..." (1976, pág. 151). Cabe decir que el tratamiento que Clarín hace del tema no tiene nada de trágico ni de angustiante para el personaje, quien no duda, como es habitual en los asiduos a lo fantástico, de su locura. 
Al finalizar el cuento en este mismo ambiguo estado mental, debemos replantear nuestro prejuicio, el cual consideraba una vuelta a la racionalidad. No hay más remedio que poner entre interrogantes la validez de la locura, pues sabemos que el psicótico "no sería capaz de distinguir esos diferentes marcos entre sí y confundiría lo percibido y lo imaginario" (Todorov, 1970, pág. 138). La explicación de por qué el autor ha insinuado esta interpretación es bastante conocida de todos: lo mismo que los excesos sexuales suelen ser relacionados con lo diabólico, los excesos de lo irracional se toleran mejor si son puestos en boca de un loco. Exactamente igual ocurre con las verdades que tocan lo tabú, son desveladas por mentes que de algún modo están desinhibidas, ya por su inocencia, ya por causas congénitas, ya por efecto del alcohol o alucinógenos. En Zurita, por citar otro cuento del asturiano, Aquiles desnuda su pensamiento en una borrachera.

Continuando con este aspecto, Todorov establece dos tipos de episodios en el relato elemental: "los que describen un estado de equilibrio o desequilibrio, y los que describen el paso del uno al otro. Los primeros se oponen a los segundos como lo estático a lo dinámico". Precisamente obervamos que este salto de lo verosímil a lo inverosímil en el plano del lector se produce sin reposo ni reflexión en el ámbito del narrador, desde que éste tropezó con la humedad.

Este mismo recurso narrativo, el que un hecho aparentemente inicuo descabale una situación o a un personaje, lo encontramos en el divertidísmo José Ido, de Fortunata y Jacinta, quien tras la ingestión de carne cree ciegamente que su mujer es adúltera y sólo entonces lo cree. Pero aún mayor paralelismo veo que existe entre éste y el cuento de Leopoldo Lugones La última carambola, en el que un personaje obsesionado por la precisión de su entretenimiento favorito, el billar, se vuelve loco al desequilibrar el peso de su bolsillo dando una limosna. Inmediatamente imagina que el Sol y la Tierra son dos enormes bolas de un billar de dimensiones cósmicas y que se va a producir un choque interplanetario. Sucede que estalla una bomba a su lado, con lo que su imaginación, de modo profético, se ha enlazado a este referente. En Mi entierro, narrado en primera persona, no contamos siquiera, como vimos, con un último desarrollo objetivo, de modo que su ambigüedad queda irresuelta. No cabe la posibilidad de interpretar la doble consecuencia narrativa como un sincretismo de dos tiempos. El cuento se desliza en ese estado intermedio entre el absurdo aparente de la locura y la ironía del escepticismo.

Indudablemente hay que hablar de la utilización por parte del escritor de un deslizamiento hacia el ensueño, hacia lo que Juan de Mairena llamaba desdeñosamente oniroscopia. La técnica no era habitual entonces, pero tampoco inconcebible. "Este método fue ya empleado en el siglo XVIII, época fértil 
en novedades extravagantes, donde fantasía y realidad se mezclan sin cesar. A este propósito Bretón cita una carta de Horace Walpole a William Cole que revela la génesis de una de sus obras, The castle of Otranto. Inspirado en un sueño redactó su obra en un estadio intermedio entre la vigilia y el sueño de un modo puramente espontáneo (cit. Duplessis, 1972, pág. 42). Narraciones de este tipo se encontraban, por supuesto, en Poe o Stevenson, pero también en la literatura peninsular, en Ros de Olano, o en Silverio Lanza poco después. Más adelante retomaré el tema.

Respecto a la contradicción entre los componentes léxicos señalada por Eberenz, pues "un difunto no habla" (1989, pág. 252), podemos ampliar dicha contradicción afirmando que tampoco un demente razona con dos lógicas, dos modos de ver el mundo, simultáneamente. Como dice Jacques Finné: "Si le lecteur sait, dès premières lignes, qu'il va lire une confession d'un dement, le récit acquiert une dimension réaliste qui exile le fantastique: la description du réel donnée par un malade sera naturellement malade" $(1980 \text {, pág. } 73)^{3}$. No es preciso ahondar más en la naturaleza del delirio como imagen que fuerza la realidad destruyendo el objeto, y basta ver cómo en Mi entierro presencia y simulación subjetiva se complementan intercambiando sus sentidos. En cambio "una secreta lógica gobierna las ensoñaciones que parecen abandonarse a los caprichos de la imaginación" (Vax, 1981, pàg. 96).

El propio Alas opinaba, hablando del estilo de Ortega Munilla, con respecto a "esa especie de enfermedad nerviosa de muchos poetas, que les hace ver junto al objeto y a veces en él mismo, las semejanzas que tiene en otros reinos de la realidad; ese prurito de la alegría no como recurso retórico, sino como efecto de la doble-vista estética del escritor [...] Es bueno ver todo lo que hay, pero es malo ver más de lo que hay" (vid. Bonet Mojica, 1984). La técnica, naturalmente más propia de la poesía, podía pasar a la prosa a través de numerosas vías, una de ellas lo fantástico (en el sentido amplio), otra por los juegos del humor, rupturas del sistema en diferentes sentidos.

Gramberg es quien atribuye a Clarín una imaginación febril (1958, pág. 204), contrapunto del escritor realista, que había dado a la novela un papel muy específico, pero que se permitía, según mostró, cierto respiro en el cuento. La profusa imaginación hasta agobiante en el estilo, que es derrochada por Galdós en sus relatos, resulta igualmente destacable. Si ahora leemos unas glosas que Menéndez Pelayo hace de Richter: "La facultad artística por excelencia es la imaginación; pero no la imaginación reproductora [...] sino la imaginación productora, o fantasía, que es el alma del mundo de nuestra alma" (cit. Bonet

3. "Si el lector sabe, desde las primeras líneas, que va a leer una confesión de un demente, el cuento adquiere una dimensión realista que aleja lo fantástico: la descripción de lo real hecha por un chiflado estará naturalmente tarada". 
Mojica, 1984, pág. 956n), y las comparamos con los artículos de La Diana mencionados, nos haremos una idea clara de lo poco claras que, en este punto, andaban las ideas. Se hace necesario citar aquí la frase de Renan que argumenta Clarín para defenderse de un ataque de Alfredo Calderón: "Es empequeñecer el mundo del pensamiento humano reducirlo a ideas claras" (La justicia, 16 de marzo de 1889). No cabe duda de que asistimos a un cambio en el planteamiento de qué deba ser lo literario, más alejado cada vez de una simple mimesis, a pesar de la cuestión palpitante, y que de la consideración de la excesiva potencia imaginadora como enfermedad, en los estudios de Jean Tissot, pasamos a su integración en el arte como un modo distinto y genuino de abordar la realidad. En este sentido el propio Clarín ofrece casos representativos, como el protagonista de La fantasía de un delegado de Hacienda, el cual llega a imaginar que acaba de morir de una pulmonía.

Lo expuesto hasta ahora me lleva a pensar que toda acción en el dominio del pensamiento lleva implícita su reacción, a veces igualmente legítima para el pensador mismo. Así Flaubert comentaba a Maupassant en una carta: “ ¿Ha creído alguna vez en la existencia de las cosas? No hay más verdad que la que hay en las relaciones, es decir, en la forma en que percibimos los objetos" (cit. Company-Ramón, 1986). De aquí al impresionismo no hay demasiados pasos.

Con todos los distingos planteables, aún el texto es lo bastante flexible como para destacar su conexión con el onirismo, en el sentido de un impulso creador, no de una resolución interpretativa o psicoanalítica. De este modo creo que lo ve también Laura de los Ríos, frente a las reservas manifiestas por Ramos-Gascón. Intentaré basar mis juicios en alguna reflexión. En Bergson leemos: "En el ensueño solemos ser indiferentes a la lógica, pero no incapaces de lógica. Diría, casi a riesgo de abordar la paradoja, que el efecto del que sueña es que razona demasiado. Evitaría el absurdo si asistiese como simple espectador al desfile de sus visiones. Pero cuando quiere a todo trance dar una explicación de ellas, su lógica, destinada a relacionar entre sí imágenes incoherentes, no hace sino parodiar la lógica de la razón y tocar en el absurdo" (1982, págs. 108-9). En el cuento hay una escena en la que el personaje-narrador, ya fundido a su cuerpo de difunto, dice soñar: "Soñé que uno de ellos — de los pies- era el Mississippí y el otro un río muy grande que hay en el norte de Asia y que yo no recordaba cómo se llamaba. ¡Qué tormento padecí por no recordar el nombre de aquel pie mío!" (pág. 170). Este soñar, sin embargo, no tiene despertar explícito alguno, aunque en el contexto es lo cierto que hubiera sido lo mismo utilizar otro verbo, del tipo pensé, o imaginé, o me pareció... Dado el grado de extrañeza alcanzado previamente no hay escalón alguno que nos señale el paso al sueño; la fluidez de las sensaciones visuales característica para Bergson de la literatura del ensueño, no cede hasta que el difunto es conducido al cementerio, y entonces se remansa sólo para crear mayor contras- 
te con las imágenes finales. Este contraste se agranda aún más porque cuando Ronzuelos, el protagonista, salta de la caja tras ser acusado por Roque Tuyo de tramposo y no ve a nadie, pensaríamos que todo lo anterior no fue más que una pesadilla y que es el momento de hacerse preguntas. Pero la "falta de tiempo disponible para detenerse , extrañarse, interrogarse, pensar" (Zambrano, 1986, pág. 27) vuelve a remitirnos a la atemporalidad de la psique mostrada en los sueños. Levantarse y no ver a nadie es como un despertarse sin salir del sueño, un acentuar la incertidumbre de si es o no real lo percibido.

La pasividad del personaje durante la mayor parte del cuento me hace pensar en una frase de Le Clézio a propósito de Les chants de Maldoror: "Celui qui dort subit l'anéantissement intermittent des facultés humaines" (1989, pág. 74) ${ }^{4}$, sólo que esta falta de conciencia que Maldoror vive como angustia es aprovechada como despiste por el autor para favorecer lo cómico.

Entramos en este punto a otro problema. ¿Cabe considerar Mi entierro como un cuento fantástico? Vaya por delante mi coincidencia con Harry Belevan en el no admitir lo fantástico como género, al menos no como género histórico. También estoy de acuerdo en considerar, como Barrenechea, que las nociones de Todorov extraño / fantástico / maravilloso, articuladas en torno a la resolución o no de la duda, son inservibles en muchos casos modernos, en los cuales el relato rechaza desde el principio que exista una verdad única $y$, por tanto no busca hallarla, crece espontáneamente sobre el eje de su ambigüedad o de su verdad ficticia. Elementos fantásticos como el desdoblamiento inicial, resuelto luego en una fusión repentina e inesperada, o la lectura de los pensamientos ajenos, no se insertan como contradicción de su contexto y lo fantástico así no llega a cuajar.

Está claro, en cualquier caso, que interpretaciones unívocas, ya desde la locura, ya desde lo fantástico, se excluyen mutuamente. Rechazada aquélla como una falsa pista dada por el autor, como primer lector que es, sobre su propio cuento, debo desestimar ésta basándome en el hecho de que los personajes no experimentan sorpresa ante la ruptura de lo verosímil, precisamente como quien, soñando, no se sorprende de poder volar. Aquí la literatura, como obra de la imaginación, "representa un universo del que se excluye la creencia (creencia en el sentido de certeza...)" (González, 1980, pág. 33). Alguien ha hablado, con mayor o menor fortuna, de lo neofantástico, que igual pudiera llamarse neomaravilloso, o también se ha propuesto el término insólito, si bien considero que en estos conceptos no se ha insistido sastante. El basculamiento que se produce en este tipo de relatos provoca que "evolucione como una nebulosa" (ibid., pág. 85), sin pretender hacerse con una objetividad inalterable.

4. "El que duerme experimenta el anonadamiento intermitente de las facultades humanas". 
Señalo esta posibilidad de hacer una lectura desde una forma narrativa contemporánea sin tratar por ello de definir Mi entierro como un cuento insólito, al estilo de La Metamorfosis kafkiana. Ahora bien, aplicado a este relato el criterio de no-discusión, de asimilación con-natural de lo extraño en lo conocido, podemos caer en la apreciación errónea de que nos hemos trasladado al terreno de lo maravilloso. El problema suele ser casi siempre puramente terminológico. Probablemente, cuando G. Sobejano utilizó aquel concepto, daba a la palabra un sentido amplio, el que emplea Vax en su Arte y literatura fantástica, diferenciando luego lo feérico de lo fantástico. Lo maravilloso-feérico, sin embargo, responde a unas leyes, aunque ajenas a la realidad, específicas y que dan coherencia interna a todo el cuento. Frente a estas leyes para-reales, "lo insólito, más sutil y perverso, nos insinúa que la vida es una ficción" (ibíd., pág. 105); ya no es fruto del miedo a lo desconocido, como lo fantástico, sino de la progresiva alienación del hombre moderno. Poco importan algunas contradicciones cuando están siendo cuestionados aspectos que afectan tanto a lo espacio-temporal, como a lo teológico o a la propia identidad. Y si en el relato fantástico el personaje tenía una función activa, se rebelaba o trataba de defender su cosmovisión, en el neofantástico pasa a ser como un centro inmóvil cuya idea de la causalidad ha sido sustituida por un vacío lógico (ibíd., pág. 63). Estas condiciones sobre las que se construye lo insólito favorecen, además, la visión cómica, la cual era improcedente en el relato fantástico tradicional. Esto es lo que sucede en Mi entierro, donde el extrañamiento viene a superponerse a las leyes del disentimiento y de la tolerancia del chiste.

La locura del personaje no es en sí sino una licencia para dejar libre la fantasía cómica, "razonable a su modo, hasta en los mayores extravíos" (Bergson, 1983, pág. 12). De aquel José Ido comentaba Clarín: “Dónde habrá cosa más graciosa que su borrachera carnal?" (Una carta y muchas digresiones, 1987, pág. 112), él que tanta facilidad demostró para el humor. Y Mi entierro es un buen ejemplo de esa "innata tendencia a establecer las asociaciones más incongruentes" de que habla Gramberg (1958, pág. 197). Este crítico define, asimismo, una de las características del humor como "la capacidad de ver y sentir yuxtapuestas y al mismo tiempo cosas del orden ideal y real que aisladamente no provocarían humorismo alguno (ibíd., pág. 78), yuxtaposición que este cuento refleja bien en el lenguaje: "exclamé enroco y seguí adelante" (pág. 167); o luego: "-Chico, le dije cuando le tuve a salto de peón, ${ }_{i} \mathrm{Ni}$ que fuera un caballo; vaya modo de comer que tienes!" (pág. 168). Del mismo modo podemos encontrar todos los criterios tradicionales que delimitan lo cómico: contradicción, desacralización, sorpresa, complicidad, juego, lógica y absurdo.

Pero este cuento entra de lleno en el tema de la muerte. ¿Cabría calificarlo de macabro? Martin Grotjahn, en su Psicología del humorismo aborda justamente la relación entre el humor y la muerte. La irreverencia, la trasgresión del 
tabú, son básicas en muchos momentos cómicos. Todo depende, sin embargo, de nuestro grado de tolerancia, es decir, de que seamos capaces de separar esa trasgresión y nuestras creencias. Así, Wenceslao Fernández Flórez contaba que "hay una circunstancia ante la cual el humorismo no puede: ante la muerte". Por su parte, comenta Antonio Espina: "Las ceremonias fúnebres suelen producir en el espectador desinteresado, o sea, ajeno en su intimidad al hecho luctuoso, reacciones de humorismo a propósito de cualquier detalle, de cualquier situación que desentone con el negativismo fundamental de lo fúnebre, de lo macabro" (1965, págs. 82-3). Estas reflexiones nos hacen pensar, sin duda, en la santa cachaza de don Angel Cuervo en su trato con los moribundos.

En Mi entierro la omnisciencia crea el desengaño, que a su vez acentúa el escepticismo necesario para levantar sobre él el humor. De esta manera, la narración en primera persona se convierte en exponente del vivir relativizado. El humorista se saldrá de sí mismo para ser en todo, para ver el derecho y el revés al mismo tiempo, y enfrentar la realidad admitida con otra realidad supuesta, superponiendo lo que nadie ve en lo que todos ven.

"No hay mayor enemigo de la risa que la emoción", dirá Bergson. No obstante, otra era la idea de lo cómico en autores anteriores. Para Taine o Tackeray, el humorista debía, en último término, despertar nuestra compasión por lo mismo que censura. De esta misma opinión era Palacio Valdés cuando afirmaba que "no fue Alas un humorista en el sentido verdadero de la palabra. Para ello le faltaba la piedad" (1941, pág. 96).

También Cejador y Frauca expondrá su opinión al respecto, más próxima a la expresada por Gómez de la Serna en Automoribundia, lo mismo que Manuel de la Revilla. Esta nueva concepción del humorismo nace más de la pura subjetividad, de una ironía filosófica, y tiene como finalidad en sí el hecho catártico del instante cómico. De una a otra encuentro el paso que va de lo social a lo individual: la risa como vía de lo didáctico, un bien para la comunidad, frente a la risa como un guiño particular entre sujetos que asisten a un mismo espectáculo, a una misma realidad castrante.

Ciñéndonos al relato podemos comprobar que participa de las visiones que acabo de exponer sobre lo cómico, si bien, al tratarse de un relato en primera persona, donde el objeto de burla es muchas veces el propio narrador ficcionalizado, pensamos más en el escéptico que se ríe de sí mismo. No sucede esto cuando la focalización es centralizada por un personaje, como ocurre en el discurso de D. Mateo, o antes, en el monólogo interior de la mala esposa (cuya técnica de entrecruzamiento de discursos distintos vemos también en Un niño maligno, cuento de A. Chéjov). De estas situaciones fácilmente podríamos extraer el juicio de Tackerey en lo referente al "desprecio por la mentira y la hipocresía” (vid. Martínez-Collado, 1988, pág. 222). Con todo, vence en el 
texto la imagen simbólica del ajedrez y el leit motif absurdo de la humedad, que nos hablan más acerca de la vida como juego pasivo.

Volviendo nuevamente al tema de la locura desde esta perspectiva, pienso que, como dice A. Espina, "la locura pone una barrera infranqueable al humor, en cuanto obnubila la conciencia. Pero es y fue una de sus fuentes, para el cuerdo [...] la incoherencia, las extravagancias del loco" (1965, pág. 85). Pero es que, además, la del humorista "viene a ser una posición arriesgada, próxima a la locura" (Vilas, 1968, pág. 60). En el texto se unifican las voces del personaje, que es el doble loco del narrador, éste, que en virtud de una licencia se autoconcede la omnisciencia, y el autor-humorista, que es quien dispone el tono y el ritmo. A estos dos elementos narrativos dedica Jean Sareil un espacio en L'écriture comique, resumiendo cómo el ritmo es el elemento más importante de la narración cómica, en cuanto que da al cuento calidad de tal, mientras que en el drama o la novela seria este papel corresponde, por lo general, a la historia (vid. Sareil, 1984, pág. 151). En cuanto al tono juzga que su papel es precisamente el de crear un ambiente en el que la desmesura parecerá la forma más habitual de hacer o de pensar (ibíd., pág. 175).

En el cuento de Clarín la primera ruptura con el plano de lo sensato crea ya un tono que justifica las restantes, hasta el cierre final, desconcertante y cargado de todas las significaciones anteriores, multiexpresivo. Conocemos la lógica del personaje, por eso nos hace gracia que compadeciendo al difunto, al cual aún no conoce, exclame: "Alguna víctima de la humedad!” (pág. 168), exclamación que inmediatamente aprovecha el artista para intercalar la voz del sereno: "dicen si ha muerto de una borrachera", sirviéndose de la mínima ambigüedad precedente. Luego, la alienación del personaje, su indiferencia ante lo que resulta ser su propio cadáver - lo cual, tratado de este modo, nunca he visto en autores anteriores-, ridiculizado incluso por el narrador, la vacilación hacia lo trágico subjetivo cuando lo más terrible parece ser no recordar el nombre de su pie-río, todo ello contribuye a que los registros tonales, realista y fantástico, satírico y grotesco, se armonicen, tras la desconcertante imagen última. Paralelamente el ritmo, rápido cuando el narrador es protagonista, más demorado cuando se practica la omnisciencia selectiva, contribuye a destacar sobre el conjunto la tensión final.

Réstame entrar en lo que de grotesco han señalado Ramos-Gascón y, sobre todo, Laura de los Ríos. En la revisión del concepto nos encontramos por un lado con la idea romántica, que subrayaba "la yuxtaposición de lo feo y hermoso, combinando lo cómico y lo trágico en orden a despertar la compasión del lector" (Ziomek, 1983, pág. 11). Así Justus Moser, Campbell, Lee Byron Jenning, Víctor Hugo..., unos destacando más los elementos repugnantes, otros los cómicos. Por otro lado, la idea de lo grotesco en el siglo XX: "No solamente 
se designa así a lo que es deforme o fantástico, sino también a todos aquellos actos o expresiones que ponen de manifiesto los aspectos sórdidos y repulsivos de la vida" (ibíd., págs. 11-12). Ziomek concreta que lo grotesco tiene un triple efecto: provocar el horror, la risa y el asombro: "Para llegar a lo grotesco - continúa - hay que añadir al humor, la sátira y la exageración que constituyen la caricatura, un elemento nuevo: la extrañeza" (1983, pág. 14). Este factor coincide con lo que Wolfang Kayser denomina distanciamiento, el cual puede ser más o menos cómico o siniestro, considerado también su juego con lo absurdo (vid. Martínez, 1984, pág. 33). La extrañeza, por lo general, en la literatura anterior al siglo $\mathrm{XX}$, era expresada por medio de personajes $\mathrm{y}$ espacios, ridículos o deformes, muchas veces simbólicos, los cuales eran tratados de modo que el lector sintiera rechazo, destruyendo así toda posibilidad de identificación.

Visto esto, personalmente no sabría decir si Mi entierro es más satírico que fantástico o viceversa. En este relato no encontramos exactamente personajes grotescos, aunque sí situaciones grotescas, las cuales son presentadas por el autor ya de modo cómico — sin intencionalidad crítica-, ya de modo satírico. La escena que más claramente podemos considerar grotesca comienza con la visión del cadáver: "Estaba en camisa, sin calzoncillos, pero con calcetines" (pág. 169). Y más adelante, a propósito de provocar el contraste con la solemnidad con la sacralidad de lo funerario, se nos cuenta: "Una de las hachas de cera se torció y empezaron a caer gotas de ardiente líquido en mis narices" (pág. 170), aumentando este contraste la descripción del gato, familiarmente enroscado junto al difunto, y un moscón sobre las narices de éste, cubiertas de cera. Posteriormente la impresión de lo grotesco desaparece bajo el humor o la sátira, reapareciendo en alguna pincelada como ese defenderse del personaje, ya en el cementerio, fémur en ristre. Por el contrario, la ironía va en aumento, apoyada en la inautenticidad que late bajo las relaciones y la conducta de los hombres. Por eso el personaje llega a decir: "Mi mujer, Perico, Clemente, el partido, don Mateo... y sobre todo Roque Tuyo, me dan asco" (pág. 176). Digamos que la situación, es decir, el comportamiento de la sociedad aquí representada, es demasiado reconocible como para ser grotesca y, de acuerdo con H. Martínez, creo que "la presencia de elementos grotescos no necesariamente justifica clasificar una obra como grotesca" (1984, pág. 31) ${ }^{5}$.

Otra cuestión sería considerar lo grotesco como un modo de explorar preocupaciones metafísicas o existenciales. Como una forma de dar salida al desengaño barroco era un juego de paradojas que envolvía al hombre en desacuerdo con su entorno, pero con la esperanza clara en una idea superior. En

5. Para este crítico, "el grotesco, aunque carezca de verosimilitud, provoca numerosas sensaciones contradictorias: sonrisa, repugnancia, sorpresa, congoja ante un mundo que está desquiciado mientras ya no encontramos apoyo alguno". (1984, pág. 25) 
el siglo diecinueve la crisis filosófico-religiosa se reflejará en la literatura haciendo que ésta se centre, progresivamente, en todo tipo de alienaciones. En este sentido, el humor, creo, sirve de alivio a la conciencia de dicha alienación.

Teniendo en consideración el momento en que pudo ser redactado Mi entierro, posiblemente tras la frustración de no ver publicados los artículos sobre el problema agrario andaluz que tantos ires y venires le debieron costar a él y a su mujer, recién casados, o tal vez por el alejamiento en que se hallaban a causa de tener nombrada la cátedra en Zaragoza, ello es que la capacidad irónica y crítica del escritor pudo haberse agudizado. No cabe objetar que tras determinados personajes el autor está tipificando, y censurando, ciertos caracteres humanos. La huella de lo moral está impresa desde la mujer adúltera hasta el inepto orador, pasando por el falso amigo y el desengaño político. La ética en la estética, como profundamente muestra Lissorgues (vid., 1980 y pról. 1989). Mi intención, no obstante, ha sido la de evidenciar la riqueza de voces que configuran este relato del genial Clarín, así como la de complicar la visión que hasta poco ha se tenía del artista, el cual, como decía Baudelaire, "no es artista más que a condición de ser dual y de no ignorar ningún fenómeno de su doble naturaleza" (1988, pág. 51). Juzgue el lector sobre la necesidad de establecer criterios para una posible clasificación de Mi entierro sin que se anule alguno de los componentes significativos que posee.

\section{BIBLIOGRAFÍA}

ALAS, Leopoldo. 1971. Solos de Clarín, Madrid, Alianza.

—. 1984. Pipá, ed. RAMOS-GASCON, Madrid, Cátedra.

-. 1985. Juan Ruiz, ed. Martín GAMERO, Madrid, Espasa-Calpe (col. Austral).

-. 1987. Mezclilla, Barcelona, Lumen.

BAUDELAIRE, Charles. 1988. Lo cómico y la caricatura, Madrid, Visor.

BERGSON, Henri. 1982. La energía espiritual, Madrid, Espasa-Calpe (col. Austral).

-. 1983. La risa, Barcelona, Orbis.

BONET MOJICA, Laureano. 1984. Clarín, Jean Paul, Baudelaire: Un tríptico simbolista. En Clarín y La Regenta en su tiempo, Oviedo, Universidad.

CLEZIO, Jean-Marie Le. 1987. Le rêve de Maldoror. En Sur Lautréamont, París, Complexe.

COMPANY-RAMÓN, José María. 1986. La realidad como sospecha, Valencia, Minneapolis.

DUPLESSIS, Yvonne. 1972. El Surrealismo, Vilassar de Mar (Barcelona), col. ¿Qué sé?

EBERENZ, Rolf. 1989. Semiótica y morfología textual del cuento naturalista, Madrid, Gredos. 
ESPINA, Antonio. 1965. El genio cómico y otros ensayos, Madrid-Santiago de Chile, Cruz y Raya (Cruz del Sur).

FINNÉ, Jacques. 1980. La littérature fantastique. Essai sur l' organisation du surnaturel, Bruxelles, Université.

GONZÁlEZ, Ana. 1980. Continuidad de lo fantástico, Barcelona, Punto.

GRAMBERG, Ernest. 1958. Fondo y forma del humorismo en Leopoldo Alas "Clarin", Oviedo, Instituto de Estudios Asturianos.

LISSORGUES, Yvan. 1989a. Clarín político, Barcelona, Lumen, v.I

—. 1989b. pról. a ALAS, Leopoldo, Narraciones breves, Barcelona, Anthropos.

LUGONES, Leopoldo. 1982. La última carambola, en Cuentos desconocidos, ed. BARCIA, Buenos Aires, Eds. del 80.

MARTÍNEZ, Herminio. 1984. El arte grotesco en las tragedias grotescas de Arniches y Valle-Inclán, New York, NYUniversity.

MARTÍNEZ-COLLADO, Antonio. 1988. Una teoría personal del arte: Ramón Gómez de la Serna, Madrid, Tecnos.

MAUPASSANT, Guy de. 1976. El horla, Barcelona, Argonauta.

PALACIO VALDÉS, Armando. 1941. Epistolario a Clarín, Madrid, Escorial.

RAMOS-GASCÓN, Antonio. 1984. Introd. a ALAS, Leopoldo, Pipá, Madrid, Cátedra.

RICHMOND, Carolyne. 1983. Introd. a ALAS, Leopoldo, Treinta relatos, Madrid, Espasa-Calpe (col. Austral).

RÍOS, Laura de los. 1965 Los cuentos de Clarín. Proyección de una vida, Madrid, Revista de Occidente.

SAREIL, Jean. 1984. L'écriture comique, París, PUF.

SOBEJANO, Gonzalo. 1985. Clarín en su obra ejemplar, Madrid, Castalia.

TODOROV, Tzvetan. 1970. Introduction à la littérature fantastique, París, Seuil.

VAX, Louis. 1981. Las obras maestras de la literatura fantástica, Madrid, Taurus.

VILAS, Santiago. 1968. El humor y la novela española contemporánea, Madrid, Guadarrama.

ZAMBRANO, María. 1986. El sueño creador, Madrid, Turner.

ZIOMEK, Harry. 1983. Lo grotesco en la literatura española del Siglo de Oro, Madrid, Alcalá. 
De inminente aparición:

\title{
GASPAR ZAVALA Y ZAMORA
}

\author{
0 B R A S \\ VOLUMEN I. \\ OBRAS NARRATIVAS \\ LA EUMENIA - ODERAY
}

Edición de Guillermo Carnero

Colección "El Bosque de Aristarco", dirigida por Alberto Blecua, $n^{\circ} 1$

Barcelona

Sirmio

1992

En coedición con la Universidad de Alicante 


\section{MIGUEL HERNÁNDEZ}

\section{OBRA COMPLETA}

Edición de Agustín Sánchez Vidal y José Carlos Rovira, con la colaboración de Carmen Alemany Bay

Madrid, Espasa Calpe, 2 vols.Colección "Clásicos

Castellanos", 1992

Se publican más de un centenar de poemas inéditos. La estructura de la edición responde a: 1) Poesía; 2) Obra teatral; 3) Prosas; 4) Correspondencia, convirtiéndose en la única edición completa existente.

Dos volúmenes con más de 2.700 páginas, en las que un amplísimo aparato textual da cuenta del conjunto de materiales previos que van creando la escritura, con una anotación centrada en estos materiales y en la determinación de las variantes, correciones y supresiones de los poemas, lo que convierte esta obra en una rigurosa edición crítica. 


\section{JOSÉ MARÍA ARGUEDAS}

\section{UNA RECUPERACIÓN INDIGENISTA DEL MUNDO PERUANO. UNA PERSPECTIVA DE LA CREACIÓN LATINOAMERICANA}

Selección e introducción de José Carlos Rovira. Barcelona, Anthropos (Suplemento n 31 . Antología temática), 1992.

Esta antología temática de José María Arguedas, estructurada en los siguientes apartados: "Fragmentos autobiográficos", "De la autobiografía a la reflexión cultural", "Reflexiones teóricas", "El mundo de la infancia recuperado: canciones quechuas", "El educador y el antropólogo", "Fragmentos narrativos", "Poesía", "Bibliografía de y sobre José María Arguedas", "Mariátegui y Luis Alberto Sánchez: en los inicios de la polémica sobre el indigenismo", se complementa con el número 128 de la Revista Anthropos (Enero de 1992): José María Arguedas. Indigenismo y mestizaje cultural como crisis contemporánea hispanoamericana, coordinado por José Carlos Rovira, en el que intervienen los más destacados especialista en la obra arguediana. 


\section{PEDRO MONTENGÓN}

\section{EL R0DRIG0}

EUDOXIA, HIJA DE BELISARI0

Selección de ODAS

Edición de Guillermo Carnero

Estudio Preliminar: 213 páginas

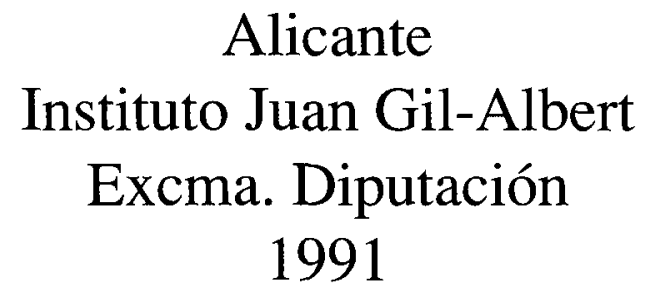

2 volúmenes

838 páginas 


\section{GABRIEL MIRó}

\section{NUESTRO PADRE SAN DANIEL EL OBISPO LEPROSO}

\section{Edición de Miguel Ángel Lozano Marco}

Se publican en un solo volumen las dos partes de una única novela en la que se nos muestra la vida y la muerte de una ciudad levítica, Oleza, a finales del siglo XIX, y las pasiones, las crueldades, los amores, los odios, los sacrificios y los heroísmos de sus habitantes. La magistral prosa de Miró intensifica esta honda meditación, realizada con lucidez y amor, sobre la condición humana, el poder transformador del tiempo y la búsqueda de la felicidad, dando cuerpo a un mundo complejo y denso, percibido y gozado con demorada sensualidad mediante los cinco sentidos. El propósito mironiano de "decir las cosas por insinuación" afecta a todos los estratos de la novela, y sitúa al escritor alicantino entre los más radicales renovadores de un género que, en aquellos años, estaba sufriendo profundos cambios.

ESPASA-CALPE. Colección AUSTRAL 1991 


\title{
GABRIEL MIRÓ
}

\section{NOVELAS CORTAS}

Nómada - La Palma rota - El hijo santo Los pies y los zapatos de Enriqueta

\author{
Edición, introducción y notas de \\ MIGUEL ÁNGEL LOZANO MARCO \\ Segunda Edición, 1991
}

Publicación del Instituto de Estudios «Juan Gil-Albert» de la Excma. Diputación Provincial, y de la Caja de Ahorros de Alicante y Murcia

Las novelas cortas de Gabriel Miró vienen a ser la contribución del escritor alicantino a ese fenómeno literario y editorial, tan característico del primer tercio de nuestro siglo, que es la aparición y proliferación de colecciones de relatos a partir del éxito de El Cuento Semanal (1907). En las páginas de esta publicación —en la que Miró consiguió una notoria fama gracias a Nómada-y en las de Los Contemporáneos aparecieron los relatos que aquí se recogen, muestras de una época todavía juvenil, de formación, en la que el escritor va afirmando su personal arte. Contiene este libro El hijo santo, interesante novela que no ha vuelto a imprimirse desde su primera edición en Los Contemporáneos (1909).

Pedidos a su librero habitual o al Instituto «Juan Gil-Albert» de la Diputación de Alicante Avda. de la Estación, 6 - ALICANTE (España) 


\section{FERNÁN CABALLERO}

\section{LA GAVIOTA}

Edición de Enrique Rubio Cremades

Espasa-Calpe, Colección Austral, 1991

Hija de un insigne folclorista, Fernán Caballero abre el camino a la gran novela española del siglo XIX. "La novela no se inventa, se observa. Escribo en lisa prosa castellana lo que realmente sucede en nuestros pueblos; lo que piensan y hacen nuestros paisanos en las diferentes clases de nuestra sociedad". Tal era su propósito teórico, que en la práctica se reviste de idealizaciones y se supedita a un objetivo moralizador de claro signo tradicional. Aunque la técnica es realista, estamos aún lejos de los grandes logros narrativos del final de la centuria. Pero nadie negará a Fernán Caballero su riqueza de observación, la plasticidad de sus cuadros y, en definitiva, la fuerza de creación que convierte La Gaviota en una obra clásica de nuestro costumbrismo. 


\section{RAMÓN PÉREZ DE AYALA}

\section{TIGRE JUAN \\ EL CURANDERO DE SU HONRA}

Edición de Miguel Ángel Lozano Marco

Con esta novela dividida en dos partes culmina el ciclo narrativo y se consuma el arte de Ramón Pérez de Ayala. Una poética historia de amor y muerte renueva en ella el viejo tema del amor como educador. La sabia organización de la estructura del relato y una espléndida prosa contribuyen a convertir esta obra en una de las más representativas de la novelística española del siglo XX.

ESPASA-CALPE. Colección AUSTRAL 1990 


\section{IGNACIO DE LUZÁN}

\section{OBRAS RARAS Y DESCONOCIDAS}

\section{VOLUMEN I}

Traducción de los Epigramas latinos de Ch. Weigel

Carta Latina de Ignacio Philalethes

Plan de una Academia de Ciencias y Artes

Informe sobre las Casas de Moneda

Informe sobre las Cartas de Van Hoey

Edición de Guillermo Carnero

Zaragoza

Institución Fernando el Católico

Excma. Diputación

1990 


\section{Gregorio Mayans y Siscar OBRAS COMPLETAS}

Dada la dificultad de encontrar en librerías o bibliotecas las obras de Mayans y Siscar (1699-1781), una de las máximas figuras de la llustración española, el intento del Ayuntamiento de Oliva, con la ayuda de la Diputación de Valencia y la Consejería de Cultura de la Generalidad Valenciana, de publicar las Obras Completas de Mayans, debe ser celebrado con el máximo elogio. Cuida de la edición Antonio Mestre, que ha centrado su interés en ofrecer un texto depurado, señalando las variantes entre las diferentes ediciones y respecto a los manuscritos autógrafos que se conservan en los fondos mayansianos. Un prólogo global de cada volumen y una breve introducción a cada una de las publicaciones mayansianas, que exponen las circunstancias concretas en que aparecieron, contribuyen a clarificar el contexto y sentido de la obra. En un principio, aparecen las obras escritas en castellano, que constan de 5 volúmenes:

Vol. I. Historia, 621 págs., Valencia, 1983.

Vol. II. Literatura, 564 págs., Valencia. 1984.

Vol. III. Retórica, 653 págs., Valencia 1984.

Vol. IV. Jurisprudencia y regalismo, 585 págs., Valencia, 1985.

Vol. V. Ensayo y varia, 489 págs., Valencia, 1986.

\section{EPISTOLARIO}

Continuandola edición del Epistolario mayansiano [Mayans y los médicos (I), Mayans yBurriel(II), Mayans y Martí(III), Mayans. Escritos económicos(IV), Mayans yNebot (V), Mayans y Pérez Bayer (VI), Mayans y Martinez Pingarrón (VII, VIII, IX)] ha aparecido últimamente:

— G. MAYANS Y SISCAR, Epistolario X, Mayans con Manuel de Roda y Conde de Aranda. Transcripción, estudio preliminar y notas de A. Mestre, Valencia 1990.

\section{Pedidos:}

Publicaciones del Ayuntamiento de Oliva (Valencia), España 


\section{JOSE CARLOS ROVIRA}

\section{HUMANISTAS Y POETAS \\ EN LA CORTE NAPOLITANA DE ALFONSO EL MAGNÁNIMO}

\section{Alicante, 1990, $256 \mathrm{pp}$.}

Publicado por el Instituto de Cultura Juan Gil-Albert de la Diputación de Alicante.

El autor realiza una reflexión, en el terreno global de la cultura, sobre la corte de Nápoles durante el reinado de Alfonso el Magnánimo y su sucesor Ferrante, es decir, sobre una historia de 1442 a finales del siglo XV. La política mediterránea de la Corona de Aragón crea en el Reino de Nápoles un enclave cultural en el que se entrecruzan producciones que anuncian el final de la Edad Media con otras que significan el comienzo del mundo renacentista. Las dos producciones alumbran una historia en la que se entremezclan temas amorosos, reflejos sociales, polémicas culturales, pasado, presente y futuro en un momento crucial de la historia europea.

Pedidos a su librero habitual 


\title{
MIGUEL HERNÁNDEZ
}

\section{CANCIONERO Y ROMANCERO DE AUSENCIAS}

\author{
Ed. de José Carlos Rovira. \\ Espasa-Calpe, col. Austral, 1990.
}

Miguel Hernández escribió el Cancionero y romancero de ausencias - conjunto de manuscritos que definen el período final del poeta - desde 1938, en plena guerra civil, hasta unos meses antes de su muerte en la cárcel de Alicante. La peripecia biográfica del excepcional poeta oriolano se cierra entonces con estos materiales que no tuvieron conclusión, ni orden definitivo. En ellos, la ausencia, las contraseñas de lo vivido, la muerte del primer hijo y las esperanzas que genera el segundo en la perspectiva de un futuro imposible, la meditación interior, constituyen un estremecedor testimonio del final de una poética y de un hombre. $\mathrm{El}$ autor de esta edición se enfrenta en la introducción y las notas con un autor que ha recorrido frecuentemente en estudios y ediciones anteriores. En la actual, una nueva propuesta de ordenación, la separación de los poemas que el poeta tachó en sus originales, la corrección de algunas lecturas, o la incorporación de varios inéditos, intentan completar la visión final de un poeta que escribe amenazado por la historia y hace de su escritura un mecanismo esencial de supervivencia.

Pedidos a su librero habitual 


\section{Juan Valera}

\section{Edición de Enrique Rubio Cremades Editorial Taurus, Colección "El escritor y la crítica”, 1990.}

Volumen monográfico que ofrece un completo panorama de los estudios más importantes dedicados a don Juan Valera. Dicha Antología crítica, producto de una difícil selección de materiales, ha querido ofrecer trabajos de calidad y, lógicamente, de muy diversa metodología. El índice se estructura teniendo en cuenta la peculiar semblanza biográfica de Valera y sus incursiones en los distintos géneros literarios de la época. La obra narrativa de Valera - novela y cuento- ocupa un lugar privilegiado en esta monografía, analizándose todo este ingente material a través de sugerentes enfoques. Antología que incluye, finalmente, una actualizada bibliografía sobre la vida y la obra de Valera. 


\section{JUAN VALERA DONA LUZ}

Edición, estudio preliminar y notas de Enrique Rubio Cremades

Espasa Calpe, Colección Austral, 1990.

Don Juan Valera, uno de los escritores más cultos y, tal vez, el mejor prosista del siglo XIX, decía a propósito de la presente novela, lo siguiente: "Acabo de leerla de nuevo como si fuea de otro. Es mi vigésima lectura, por lo menos, y lo hallo todo tan bien, y tan elegantemente dicho, y $\tan$ hondamente pensado, que leo sin poder dejar el libro, hasta que termino". La crítica ha visto generalmente en Doña Luz una obra complementaria de Pepita Jiménez, señalando que el conflicto entre el amor espiritual y el humano se plantea en ella en términos más dramáticos y complejos. El talento de Valera brilla aquí en los finos análisis psicológicos y en la gradación del relato, al tiempo que su arte nos brinda cuadros de época, de plasticidad inigualable, que componen todo un retablo de la vida española del último tercio del siglo XIX. 


\section{DAVID T. GIES y RUSELLP. SEBOLD, eds.}

\section{HISTORIA Y CRÍTICA \\ DE LA LITERATURA ESPAÑOLA}

Vol. 4: El siglo XVIII

Suplemento

Barcelona, Editorial Crítica

\section{ÍNDICE:}

Prólogo. Bibliografía monográfica. Teoría novelística en la primera Ilustración (Pérez Magallón). El sentido del término 'neoclásico' (Sebold). En la Academia del Buen Gusto (Tortosa Linde). Melancolía y tumbas en la poesía dieciochesca (Carnero). La polémica teatral de 1978 (Aguilar Piñal). Traducción y teatro en el siglo XVIII español (Lafarga). María Rosa Gálvez de Cabrera y la defensa del teatro neoclásico (Rudat). El estilo humano de Feijoo (McClelland). Feijoo, fisonomista (Fabbri). Torres Villarroel, costumbrista moderno (Sebold). Utopía en los 'Pronósticos' de Torres (Zavala). 'La Giganteida' de Luzán (Egido). Moratín en 'El arte de las putas' (Gies). Ilustración y toros (Sebold). Características y estructura del sainete (Dowling). Los sainetes de Ramón de la Cruz (Vilches de Frutos). El verso lírico de Huerta (Lama Hernández). La otra tragedia original de Huerta (Sebold). Lectura y escritura en 'Fray Gerundio' (Briesemeister). Las 'Cartas marruecas' y la novela (Baquero Goyanes). Cadalso, buen amigo (Gies). Sentimentalismo y pasión en Jovellanos y Cadalso (Dowling). Jovellanos, dramaturgo romántico (Sebold). Josefa Amar y Borbón y la educación femenina (McClendon). Batillo, poeta (Polt.). Cienfuegos: Ilustración y revolución (Gies). Quintana y el romancero (Dérozier). Samaniego en 'El jardín de Venus' (Palacios Fernández). Samaniego, fabulista: De la deuda a la originalidad (Palacios Fernández). Autobiografía y romanticismo en 'El viejo y la niña' (Dowling). 'El sí de las niñas': Realidad y ficción realista (Sebold). Trigueros: traductor, refundidor, poeta, dramaturgo, novelista (Aguilar Piñal). Las novelas de Zavala y Zamora (Camero). Guía Bibliográfica. 


\section{GUILLERMO CARNERO \\ LAS ARMAS ABISINIAS}

\section{Ensayos sobre Literatura y Arte del siglo $X X$}

Barcelona, Anthropos, 1989

400 páginas - 34 ilustraciones en color

\section{Í N D I C E :}

El concepto de responsabilidad social del escritor en Miguel de Unamuno. Salvador Rueda: teoria y práctica del Modernismo. El tránsito del Modernismo a la Vanguardia en José Juan Tablada: del Japón exótico al haikú. Primitivismo, sensacionismo y abstracción como actitudes de ruptura cultural en la literatura y el arte de Vanguardia. La gastronomía del Futurismo italiano. La prehistoria del Superrealismo. El juego lúgubre: la aportación de Salvador Dali al pensamiento superrealista. La chuleta asada como metáfora epistemológica en el pensamiento de Salvador Dalí. José Moreno Villa y las orientaciones de la Vanguardia española. Luis Cernuda y el purismo poético: Perfil del Aire. El problema del conocimiento en la trayectoria poética de Vicente Aleixandre. "Conocer" y "saber" en Poemas de la Consumación y Diálogos del Conocimiento de Vicente Aleixandre. La generación poética de $1936 .$. hasta 1939. Miguel Hernández y el cambio estético en la España de los años treinta. Precedentes de la poesía social de la postguerra española en la anteguerra y guerra civil. La poética de la poesía social en la postguerra española. Apuntes para la historia del Superrealismo en la poesía en español de la alta postguerra. Juan García Hortelano: del realismo a la experimentación. La novela faraónica de Luis Goytisolo. 


\section{DAVID T. GIES}

\section{EL ROMANTICISM0}

\section{(El escritor y la crítica)}

\section{Madrid, Taurus, 1989 \\ 381 páginas}

\section{ÍNDICE:}

Nota preliminar (Gies). El romanticismo (Borao). El romanticismo en España (Tubino). Sobre el nombre español del dolor romántico (Sebold). ¿Literatura 'prerromántica' o literatura 'ilustrada'? (Froldi). Nota histórica sobre el origen de la palabra 'romántico' (Becher). La palabra 'romanticismo' en España (Peers). El lenguaje romántico de los periódicos madrileños publicados durante la monarquía constitucional(1820-1823)(Cullen). Elnaranjo romántico: Esencia del costumbrismo (Herrero). Tendencia actuales en el entendimiento y estudios del romanticismo español (Río). La reacción anti-romántica en España (Shaw). La autointerpretación del romanticismo español (Varela). ¿Existe el romanticismo español? (Picoche). La presencia del ideario romántico alemán en la estructura y evolución teórica del romanticismo español (Juretschke). Romanticismo y revolución (Escobar). Romanticismo de acción y romanticismo de evasión (Poullain). El romanticismo en España (Tarr). 


\title{
ÁNGEL L. PRIETO DE PAULA
}

\section{LA LLAMA Y LA CENIZA \\ INTRODUCCIÓN A LA POESÍA DE CLAUDIO RODRÍGUEZ}

\author{
Salamanca, Universidad, 1989 \\ 224 páginas
}

Claudio Rodríguez, poeta perteneciente al grupo poético de los años cincuenta, es uno de los escritores españoles de mayor originalidad de todo el siglo XX. El presente estudio analiza detalladamente la inserción del autor en un panorama en el que parece un extraño. Sin apenas vínculos con la tradición española (salvo que nos remontemos al siglo XVI), y con no demasiadas concomitancias con la lírica coetánea extranjera, Claudio Rodríguez aparece en estas páginas como el dueño de un universo cuyo contorno aparente se identifica con una realidad trascendida. Para el desciframiento de su mundo poético se han examinado su particular sistema simbólico, los nudos temáticos, las connivencias expresivas con la mística y, en fin, su lenguaje tropológico. Se cierra el libro con un recorrido por los poemarios de Claudio Rodríguez hasta 1989, desbrozándose las dificultades interpretativas y ofreciéndose soluciones de lectura.

Pedidos a su librero habitual o al

Servicio de Publicaciones de la Universidad de Salamanca

Apartado 325

37080 SALAMANCA 


\section{RUSSELL P. SEBOLD}

\section{El rapto de la mente POÉTICA Y POESÍA DIECIOCHESCA}

Segunda edición, corregida y aumentada con cinco nuevos capitulos y una Introducción, de un estudio clásico, no reeditado desde 1970 .

\section{CONTENIDO:}

Introducción: unidad y música. Prólogo: sobre la actualidad de las reglas. Contra los mitos antineoclásicos españoles. Análisis estadístico de las ideas poéticas de Luzán: sus orígenes y su naturaleza. Martin Sarmiento y la doctrina neoclásica. Menéndez Pelayo y el supuesto casticismo de la crítica de Forner en las Exequias. Sobre el nombre español del dolor romántico. Alcalá Galiano y la literatura dieciochesca: paradoja histórica y visión filosófica. Interián de Ayala en el neoclasicismo español. Un padrón inmortal de la grandeza romana: en torno a un soneto de Gabriel Alvarez de Toledo. Tomás de Iriarte, poeta de rapto racional. Dieciochismo, estilo mistico y contemplación en La esposa aldeana de Iglesias de la Casa. Siempre formas en grandes modeladas: sobre la visión poética de Quintana. Neoclasicismo y creación en la Raquel de García de la Huerta. Autobiografía y realismo en El si de las niñas. El texto de una de las perdidas Cartas de Ibrahim de Meléndez Valdés.

Barcelona, Editorial Anthropos, 1989 


\title{
MIGUEL ÁNGEL LOZANO MARCO
}

\section{La literatura como \\ intensidad. Seis lecciones \\ (Clarín, Unamuno, \\ Azorín, Miró, Pérez de Ayala)}

\author{
Publicado por la \\ CAJA DE AHORROS PROVINCIAL \\ DE ALICANTE, 1988
}

En el presente libro se recoge media docena de estudios sobre esos cinco protagonistas del periodo literario de finales del XIX y comienzos de nuestro siglo. Contiene los ensayos «El relato Las dos cajas en la narrativa de Clarín", "Unamuno: Una historia de amor y Del sentimiento trágico de la vida", "Azorín. Una lectura de Un pueblecito: Riofrio de Avila», "El hijo santo, novela de Gabriel Miró. Consideraciones sobre un olvido", "En el umbral de las novelas poemáticas: Pilares, novela inconclusa de Pérez de Ayala" y "Azorín en la obra literaria de Ramón Pérez de Ayala».

Pedidos a su librero habitual 


\section{RAMÓN LÓPEZ SOLER}

\section{Jaime el Barbudo, 0 sea la sierra de Crevillente y Las señoritas de hogaño y las doncellas de antaño}

Edición crítica, estudio preliminar y notas de ENRIQUE RUBIO CREMADES y MARIA DE LOS ANGELES AYALA

Editorial Caballo-Dragón, Sabadell, 1988

Jaime el Barbudo y Las señonitas de hogaño y las doncellas de antaño se publicaron en Barcelona, por A. Bergnes, en el año 1832, no habiéndose editado ninguna de estas novelas en años posteriores. Los autores de la presente edición analizan el ideario estético de López Soler y sus artículos aparecidos en El Europeo y El Vapor, imprescindibles para el conocimiento de la introducción del Romanticismo en España. De igual forma se estudian en apartados distintos ambas novelas. En lo que respecta a Jaime el Barbudo destacan los capítulos que analizan el contexto histórico y las aventuras protagonizadas por este personaje, los recursos narrativos, disposición de la obra... En lo concerniente a Las señoritas de hogaño se hace especial hincapié en las fuentes literarias, en conexión con la obra del prolífico autor frances Scribe. La intencionalidad del autor, trama, enredo y otros aspectos significativos aparecen también detenidamente estudiados. Edición en la que se incluye una amplia bibliografia sobre la novela del siglo XIX, revisada y actualizada.

Pedidos a su librero habitual 


\title{
Juan Antonio Ríos Carratalá VICENTE GARĆ́A DE LA HUERTA (17341787)
}

\author{
Badajoz, 1987, 290 pp.
}

Publicado por la Diputación Provincial de Badajoz.

Colección «Rodríguez Moñino», n. ${ }^{\circ} 6$

El autor realiza un estudio que comprende las diferentes facetas y obras del destacado dramaturgo dieciochesco. Tras una sintesis bio-bibliográfica sobre el mismo, aborda el análisis de La Raquel -véase su edición en Ed. Cátedra, 1988-y el resto de su producción dramática, el Theatro Hespañol y su polémica, la poesía y algunas obras menores de carácter histórico. El resultado es una imagen completa y matizada de un autor hasta hace poco sólo parcialmente conocido.

\section{Juan Antonio Ríos Carratalá}

\section{ROMÁNTICOS Y PROVINCIANOS}

\section{(La Literatura en Alicante, 1839-86)}

\author{
Alicante, 1987, 184 pp. \\ Publicado por la Universidad de Alicante y \\ la Caja de Ahorros Provincial de Alicante
}

El autor nos presenta una historia provincial de la literatura que trata de evitar los componentes negativos que han caracterizado este género de estudios. Su objetivo es resaltar la importancia del ámbito provinciano para el análisis de la letras decimonónicas y mostrar hasta qué punto aspectos esenciales de la literatura nacional pueden y deben ser matizados desde esta perspectiva imprescindible para una verdadera historia literaria.

Pedidos a su librero habitual o al Secretariado de Publicaciones,

Universidad de Alicante - Apdo. de Correos 99 03080 ALICANTE 


\section{El señor de Bembibre}

de

\section{ENRIQUE GIL Y CARRASCO}

Edición crítica, estudio preliminar y notas de ENRIQUE RUBIO CREMADES

Publicada por Cátedra, Madrid, 1986, 392 pp.

Estudio en el que se analiza la múltiple producción literaria de Enrique Gil y Carrasco, desde sus artículos de crítica literaria insertos en los periódicos El Correo Nacional, El Laberinto, El Semanario Pintoresco Español..., hasta su obra lírica. De igual forma ocupan un lugar relevante en este estudio sus articulos de costumbres y sus relatos de viaje, bocetos imprescindibles para la posterior elaboración de su novela El señor de Bembibre.

El texto utilizado corresponde a la edición princeps, publicada en el año 1844 por el conocido editor don Francisco de Paula y Mellado. En esta primera edición existen ligeras erratas no sólo de estilo sino también en lo que respecta a ciertos patronímicos, errores corregidos en la presente edición y que figuran en notas a pie de página. En esta introducción crítica se analiza también la producción novelística del autor anterior a la publicación de El señor de Bembibre, novelas en las que figuran determinados recursos narrativos que se utilizarán también en la novela estudiada. Finalmente, en un amplio apartado se estudian los recursos literarios utilizados por Enrique Gil, las fuentes históricas y literarias y la relación de su relatu con la conocida desamortización de Mendizáhal.

Pedidos a su librero habitual 


\section{UNA NOVELA ESPAÑOLA DEL SIGLO XVIII}

\section{El Valdemaro \\ (1792) \\ de}

\section{VICENTE MARTÍNEZ COLOMER}

Edición crítica, estudio preliminar y notas de GUILLERMO CARNERO

Publicada por el Instituto "Juan Gil-Albert" de la Excma. Diputación Provincial de alicante

1985

Vicente Martínez Colomer nació en Benissa (Alicante) en 1762 y murió en Valencia en 1820 . Fue poeta y autor de obras históricas, religiosas y narrativas. Entre todas ellas destaca El Valdemaro, novela de aventuras y lances extraordinarios, que refleja a la perfección el espíritu de un siglo XVIII ya plenamente romántico, al introducir lo sobrenatural en el entramado de la vida real y presentar la pasión como el principal motor de las acciones humanas.

El Valdemaro fue uno de los grandes éxitos editoriales de su tiempo, alcanzando cinco ediciones entre 1792 y 1822.

Pedidos a su librero habitual o al Instituro "Juan Gil-Albert" de la Diputación Provincial de Alicante Avenida de la Estación, 6 - ALICANTE (España) 


\section{MIGUEL ÁNGEL LOZANO MARCO}

\section{Del relato modernista a la novela poemática: la narrativa breve de Ramón Pérez de Ayala}

PREMIO FASTENRATH 1987

Publicado por la Universidad de Alicante y la Caja de Ahorros Provincial

Estudia el autor la evolución y las peculiaridades de este sector de la narrativa de Pérez de Ayala (tratado, hasta este volumen, de forma fragmentaria), poniéndolo en relación con la totalidad de su obra -novela, poesía, ensayo-y con el coherente sitema de ideas que la sustenta. Presta atención a las influencias recibidas, a las etapas atravesadas por el escritor asturiano, y a los diversos estilos que preceden el hallazgo de esa fórmula literaria que da como resultado feliz una de las más originales creaciones novelísticas de nuestra Edad de Plata: la novela poemática.

Pedidos a su librero habitual o al

Secretariadode Publicaciones. Universidad de Alicante 03080 ALICANTE (España) 


\section{Clásicos Taurus}

\section{Directores: \\ Alberto Blecua, Guillermo Carnero y Pedro Cátedra}

Una cuidada colección de textos literarios, de atractiva presentación y precio muy asequible, en ediciones preparadas por especialistas de reconocido prestigio, a los que se han encomendado el establecimiento de los textos y sus variantes, sintéticos estudios preliminares y un amplio repertorio de notas léxicas, historiográficas y críticas.

1. Juan Ruiz, Arcipreste de Hita, Libro de buen amor. Edición de Jacquest Joset.

2. Fray Luis de León, Poesía completa. Edición de Guillermo Serés.

3. Miguel Hernández, Antología poética. El labrador de más aire. Edición de José Carlos Rovira.

4. Gustavo Adolfo Bécquer, Rimas. Leyendas escogidas. Edición de Rubén Benítez.

5. Luis de Góngora, Poesía selecta. Edición de Antonio Pérez Lasheras y José María Micó.

6. Juan García Hortelano, Nuevas amistades. Edición de Juan Cano Ballesta.

7. José de Espronceda, Antología poética. Edición de Rubén Benítez.

8. Juan Valera, Pepita Jiménez. Edición de Enrique Rubio Cremades.

9. Leopoldo Alas «Clarín», Su único hijo. Edición de José Mª Martínez Cachero.

10. Gaspar Melchor de Jovellanos, Poesía. Teatro, Prosa literaria. Edición de John H. R. Polt.

11. Poesía castellana de la Edad Media. Edición de Francisco López Estrada y Mª Teresa López.

12. Gabriel Miró, Las cerezas del cementerio. Edición de Miguel Ángel Lozano.

13. Teatro castellano de la Edad Media. Edición de Ronald E. Surtz.

14. Gerardo Diego, Poesía española contemporánea. Edición de Andrés Soria Olmedo. 


\section{COLECCIÓN "EL ESCRITOR ALICANTIN0 Y LA CRÍTICA"}

Una iniciativa de la Caja de Ahorros Provincial de Alicante con el propósito de divulgar y poner al día la bibliografía dedicada a los más destacados escritores alicantinos.

\section{Cada volumen incluye lo siguiente:}

- Una monografía preliminar sobre el autor y sobre el estado actual de la historiografía y la crítica a él dedicadas.

- Un capítulo bibliográfico de y sobre el autor

- La recopilación de la más importante bibliografía que lo concierne, atendiendo tanto a la tradición crítica como a la relevancia e inaccesibilidad de los textos

- Una propuesta de líneas de investigación

Número 1: CARLOS ARNICHES

Edición de Juan A. Ríos Carratalá

225 páginas. Publicado en 1990

Número 2: PEDRO MONTENGÓN

Edición de Guillermo Carnero

237 páginas. Publicado en 1991

Número 3: JUAN GIL-ALBERT

Edición de José Carlos Rovira

247 páginas. Publicado en 1991

Número 4: MIGUEL HERNÁNDEZ

Edición de Carmen Alemany

Publicado en 1992

Números sucesivos serán dedicados a AZORÍN, GABRIEL MIRÓ y otros. Pedidos a Caja de Ahorros Provincial de Alicante. Biblioteca. c/ Mayor, 3. ALICANTE. 


\section{Universidad de Alicante Ediciones microfotográficas}

\section{AULADELL PÉREZ, M.A.}

La Guía y aviso de forasteros que vienen a la Corte del Licenciado Antonio Liñán y Verdugo en su contexto literario.

Ed. 1991 - 2 microfichas, 10 '5 cm.

ISBN: 84-7908-015-9

\section{REQUENA SÁEZ, M.C.}

La obra literaria de Salvador Sellés

Ed. 1991 - 1 microficha, $10^{\prime} 5 \mathrm{~cm}$.

ISBN: 84-7908-017-5

\section{VILLAVERDE PÉREZ, A.}

Estudio y edición de la obra de Tapia, poeta cancioneril Ed. 1991 - 1 microficha, $10^{\prime} 5 \mathrm{~cm}$.

ISBN: 84-7908-018-3

Pedidos a:

Secretariado de Publicaciones

Universidad de Alicante

Ap. de Correos 99

03080 ALICANTE 


\section{PUBLICACIONES DEL INSTITUTO DE CULTURA "JUAN GIL-ALBERT"}

\section{Organismo Autónomo de la Excma. Diputación Provincial de Alicante}

\section{Algunos títulos}

Colección "Ensayo e Investigación"

Emilio La Parra López, El primer liberalismo español y la Iglesia. Las Cortes de Cádiz, Pról. de A. Mestre, 1985, 320 pp.

VV.AA., La Ilustración Española, Actas del Coloquio Internacional celebrado en Alicante, Ed. de A. Alberola y E. La Parra, Pról. de A. Mestre, 1986, 544 pp.

DarioPuccini, Miguel Hernández: vida, poesía y otros estudios hernandianos, Pról. de J.C. Rovira, 1987, 229 pp.

Francisco Márquez Villanueva, La esfinge mironiana y otros estudios sobre Gabriel Miró, 1989, 141 pp.

C. Morange, Siete calas en la crisis del Antiguo Régimen español y un panfleto clandestino de 1800, 1990, $256 \mathrm{pp}$.

J. Pérez Magallón, En torno a las ideas literarias de Mayans, 1991, 290 pp.

\section{Colección "Espejo de Clio"}

R. Lea, Los moriscos españoles: su conversión y expulsión. Estudio preliminar y notas de R. Benitez, 1990, 445 pp.

Francisco Pérez Bayer, Por la libertad de la literatura española, Estudio preliminar y notas de Antonio Mestre Sanchis, 1991, 587 pp.

Sermones revolucionarios del trienio liberal (1820-1823). Estudio preliminar de Gérard Dufour, 1991, 211 pp. 


\section{Coediciones}

Mario Martínez Gomis, La Universidad de Orihuela (1610-1807). Un centro de estudios superiores entre el Barroco y la Ilustración, 2 vols., Pról. de A. Mestre, 1987, 316 y 267 pp.

A. Alberola, ed., Estudios sobre Altamira. Actas del Coloquio celebrado en Alicante, 1987, $431 \mathrm{pp}$.

J. A. Ferrer Benimeli (Coordinador), Masonería, Revolución y reacción. IV Simposium Internacional de Historia de la Masonería Española (Alicante, 27-30 de septiembre de 1989). 2 vols, 1990, 1095 pp.

Colección "Literatura y Crítica"

1. Vicente Martínez Colomer, El Valdemaro. Edición, introducción y notas de Guillermo Carnero, 1985, 257 pp.

2. Manuel Ciges Aparicio, El libro de la vida trágica. Del cautiverio. Edición, introducción y notas de Cecilio Alonso, 1985, 454 pp.

3. Manuel Ciges Aparicio, El libro de la vida doliente. Del hospital. Edición, introducción y notas de Cecilio Alonso, 1985, 245 pp.

4. Manuel Ciges Aparicio, El libro de la crueldad. Del cuartel y de la guerra. Edición, introducción y notas de Cecilio Alonso, 1986, 425 pp.

5. Manuel Ciges Aparicio, El libro de la Decadencia. Del periódico y de la política. Edición, introducción y notas de Cecilio Alonso, 1986, 407 pp.

6. Gabriel Miró, Novelas cortas. Obras Completas, vol. V. Edición, introducción y notas de Miguel Ángel Lozano, 1986; segunda edición, 1991, $382 \mathrm{pp}$.

7. Cornelia Bororquia o la víctima de la Inquisición. Edición, introducción y notas de Gérar Dufour, 1987, 214 pp.

8. Gabriel Miró, El libro de Sigüenza, Obras Completas, vol. XI. Edición, introducción y notas de Ricardo Landeira, 1990, 320 pp.

9. Gabriel Miró, El humo dormido, Obras Completas, vol. XII. Edición, introducción y notas de Edmund L. King, 1991, 240 pp.

10. Pedro Montengón, Obras, vol. I, El Rodrigo; vol II, Eudoxia, hija de Belisario. Selección de odas. Edición, introducción y notas de Guillermo Carnero, 1991, 475 y 358 pp. 


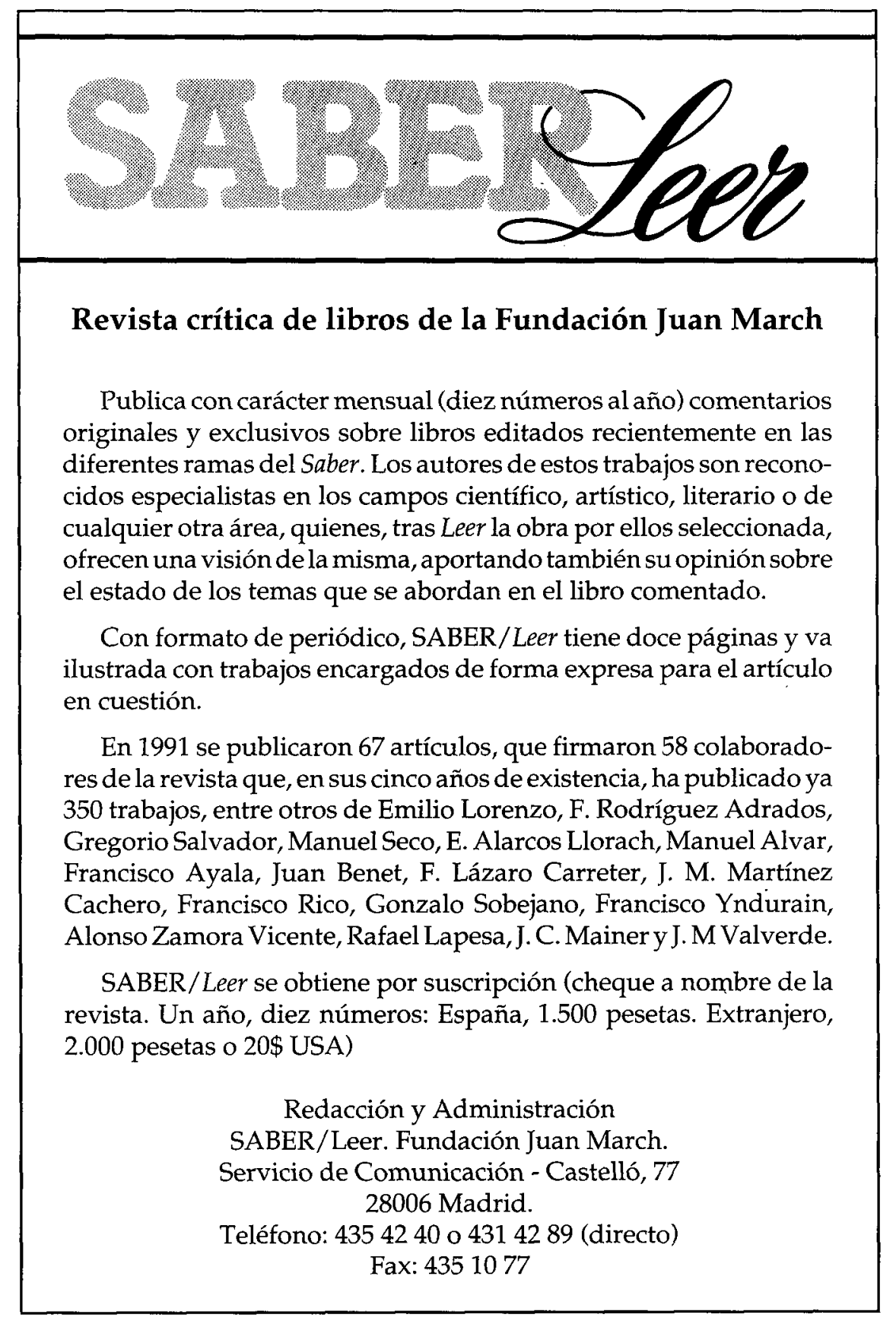




\section{ANALES}

GALDOSIANOS

Publica anualmente artículos, reseñas y documentos sobre la obra de Benito Pérez Galdós y otros autores del siglo diecinueve, y textos para la historia intelectual de la España de Galdós y sobre los problemas teóricos de la novela realista.

Directores Honorarios: Rodolfo Cardona y John Kronik

Director: Peter A. Bly

Redactores: Alicia Andreu, Alfonso Armas Ayala, Carlos Blanco Aguinaga, Brian J. Dendle, Peter B. Goldman, Germán Gullón, Hans Hinterhäuser, Juan López-Morillas, Jenifer Lowe, Carmen Menéndez Onrubia, Agnes Moncy, Pedro Ortiz Armengol, Geoffrey Ribbans, Eamonn Rodgers, Harriet Turner, Diane F. Urey, J. E. Varey, James Whiston.

Asistenta: Paulette Bark

REDACCIÓN Y ADMINISTRACIÓN:

Department of Spanish \& Italian, Queen's University

Kingston, Ontario, Canada K7L 3N6

FAX NUMBER:(613) 545-6300 


\section{Boletín de la Fundación Federico García Lorca}

Revista fundada en 1987, aparece dos veces al año y en ella se publican trabajos de investigación sobre obras literarias del siglo XX y más especificamente relacionadas con Federico García Lorca, su generación y su entorno.

El Comité de Redacción está presidido por D $D^{a}$ Isabel García Lorca, Presidente de la Fundación Federico García Lorca, y a él pertenecen:Margarita Ucelay, Prof ${ }^{a}$ Emérita de Barnard College; Andrew A. Anderson, Univ. de Detroit; Christopher Maurer, Vanderbilt University; y Piero Menarini, Univ. de Parma. El Director Literario es el Prof. Mario Hernández, de la Universidad Autónoma de Madrid, y el Director Gerente, Manuel Fernández-Montesinos, Secretario de la Fundación Federico García Lorca.

La finalidad del Boletín de la Fundación es:

- Informar sobre la aparición de nuevos materiales de interés para el conocimiento y estudio de la vida y obra de Federico García Lorca: manuscritos, dibujos, cartas, etc.

- Poner en conocimiento de los lectores aspectos de la vida y obra de otros escritores y artistas valiosos, aunque menos conocidos.

- Estudiar la influencia de movimientos artísticos y literarios en la obra de Lorca, así como su influencia sobre el arte posterior.

- Estudiar nuevas manifestaciones artísticas, especialmente en países de habla castellana.

- Mantener al día a las personas interesadas en la obra de García Lorca sobre la ingente bibliografía lorquiana.

- Informar sobre las actividades de la Fundación Federico García Lorca. 


\title{
ANALES DE LA LITERATURA ESPAÑOLA CONTEMPORÁNEA
}

\author{
General Editor \\ Luis T. González-del-Valle \\ Editors \\ Kathleen Glenn and Darío Villanueva \\ Associate Editors \\ Margarita Santos Zas and Mercedes Tasende Grabowski
}

Anales de la literatura española contemporánea publishes scholarly articles on all aspects of twentieth century Spanish literature (from Modernismo and the Generation of 1898). It also includes panoramic articles on the Spanish theater during the preceding year, book reviews of critical and creative volumes, and bibliographic studies. Manuscripts are welcome. They should be between 10 and 25 typewritten pages (including notes) and prepared in accordance with the MLA Handbook. The original, an abstract in the language of the essay, and two additional copies of both must be accompanied by unattached return postage. Articles may be written in ENGLISH or SPANISH.

Published and Forthcoming Articles: On Rafael Alberti, Fernando Arrabal, Azorín, Juan Benet, José Manuel Caballero Bonald, Camilo José Cela, Miguel Delibes, Jesús Fernández Santos, Federico García Lorca, Ángel González, Juan Goytisolo, Luis Goytisolo, Carmen Laforet, Juan Marsé, Carmen Martín Gaite, Luis Martín Santos, Emilio Prados, Elena Quiroga, Claudio Rodríguez, Gonzalo Torrente Ballester, Esther Tusquets, Francisco Umbral, Miguel de Unamuno, Ramón del Valle-Inclán, etc. Special issues on 20th Century Spanish poetry, drama / theater and narrative fiction are being published starting in 1991.

$\begin{array}{lcc}\text { Subscripitons rates are: } & \text { one year } & \text { two years } \\ \text { Individuals } & \$ 18.00 & \$ 32.00 \\ \text { Institutions } & \$ 45.00 & \$ 80.00\end{array}$

Please send correspondence, manuscripts, subscriptions and exchanges to: Luis T. González-del-Valle, ALEC, Departament of Spanish and Portuguese, University of Colorado, Campus Box 278, Boulder, CO 803090278, USA. Send manuscripts from Europe to: Darío Villanueva, ALEC, Departamento de Literatura Española, Facultad de Filología, Universidad de Santiago de Compostela, Santiago de Compostela, Spain. 


\section{CASA DE VELÁZQUEZ Últimas publicaciones:}

MÉLANGES DE LA CASA DE VELAZQUEZ - T XXVI - 1990

Fasc. 1 - Antiquité et moyen âge

Fasc. 2 - Époque moderne

Fasc. 3 - Époque contemporaine

GEOGRAPHIE D'UNE ESPAGNE EN MUTATION

PROSPECTIONS AÉRIENNESII - F. Fourneau - A. Humbert - M. Valenzuela

Série Recherches en Sciences Sociales - IX

L'ANDALOUSIE DANS L'EUROPE

L'ESSOR DU SECTEUR FRUITIER ET MARAICHER - C. de los Llanos

Série Recherces en Sciences Sociales - X

ÉVOLUTION DES PAYSAGES ET AMÉNAGEMENT DUTERRITOIRE EN ANDALOUSIE OCCIDENTALE - F. Fourneau - Y. Luginbuhl - B. Roux

Série Recherches en Sciencies Sociales - XI

L'ÉLEVAGE DANS LE ROYAUME DE CASTILLE SOUS LES ROIS CATHOLIQUES (1454-1516) - Marie-Claude Gerbert

Série Etudes et Documents - VI

LAMARCHE SUPERIEURED'AL-ANDALUSETL'OCCIDENTCHRÉTIEN Actes recueillis et présentés par Philippe Senac

Série Archéologie - XV

IMPLANTATION RURALE ANTIQUE SUR LE BAS-GUADALQUIVIR IV

Michel Ponsich

Série Archéologie - XVI

TOLÈDE ET L'EXPANSION URBAINE EN ESPAGNE (1450-1650)

Rencontres de la Casa de Velázquez

MADRID EN LA ÉPOCA MODERNA: ESPACIO, SOCIEDAD Y CULTURA Actes colloque

Co-édition Univ. Autónoma de Madrid - Casa de Velázquez

LES UTOPIES DANS LE MONDE HISPANIQUE - Actes colloque

Série Universidad Complutense de Madrid - Casa de Velázquez, 7

EL BANDOLERO Y SU IMAGEN EN EL SIGLO DE ORO - Actes colloque Co-édition: Centre de Recherche sur l'Espagne des XVIe et XVIIe s. Edad de Oro (UAM) - Universidad Internacional Menéndez Pelayo - Casa de Velázquez 


\section{IL CONFRONTO LETTERARIO}

QUADERNI DEL DIPARTIMENTO

DI LINGUE E LETTERATURE STRANIERE MODERNE DELL'UNIVERSITÀ DI PAVIA (ITALIA)

\section{Consiglio Direttivo:}

GIOVANNI CARAVAGGI, GIORGIO CUSATELLI, GIORGETTO GIORGI, TOMASO KEMENY, FAUSTO MALCOVATI, LORENZA MARANINI, GIUSEPPINA RESTIVO, CESARE SEGRE, GIORGIO VECCHI.

\section{Comitato Redazionale:}

AURELIO PRINCIPATO, VINCENZA GINI, GIUSEPPE MAZZOCCHI.

Direzione, redazione, amministrazione e stampa:

GRAFISCHENA s.p.a., viale Stazione 177 - 72015 Fasano di Puglia

Periodico semestrale. In corso di registrazione al Tribunale di Brindisi.

Direttore Responsabile: Carlo Schena.

Abbonamento 1989: ( 2 numeri), lire 28.000; estero ( 2 numeri), lire 33.000 .

Copia singola, lire 16.000; estero, lire 20.000.

Per $\mathrm{i}$ versamenti in conto corrente postale servirsi del $n .{ }^{\circ}$ 13147723, intestato a GRAFISCHENA, viale Stazione 177 . 72015 Fasano di Puglia.

La collaborazione è subordinata all'invito da parte del Consiglio Direttivo della Rivista. 


\section{CUADERNOS DE INVESTIGACIÓN FILOLÓGICA}

\section{CONTENIDO DEL TOMO XVI (1990)}

José Luis MENDIVIL GIRO, El concepto de "locución verbal" y su tratamiento léxico - María Ángeles NAVAL, Retórica del humor y público ilustrado en el Epistolario de Cadalso - Miguel a. MURO MUNILLA, Cuestiones de técnica narrativa en los articulos costumbristas de El Pobrecito Hablador - Carmen LOZANO BLASCO, La función del coro en el teatro de Valle-Inclán - Alberto ACEREDA EXTREMIANA, Gerardo Diego por tierra de La Rioja Túa BLESA, "El silencio y el tumulto" - Miguel IBAÑEZ RODRÍGUEZ, La localización de los personajes en el teatro de Samuel Beckett - C. CORNUT y F. COLLADO, Wars of words: A historical and rhetorical analysis of political and literary texts in the English $1830^{\prime}$ 's and 1840's - Ma Carmen LOPEZ SAENZ, La dimensión existencial en la semiología de Merleau-Ponty - J. RUBIO, "La cueva de las maravillas": una leyenda desconocida de Augusto Ferrán Entrevista a Eugenio Coseriu - RESEÑAS

\section{INFORMACIÓN}

Cuadernos de Investigación Filológica

Colegio Universitario de La Rioja

Servicio de Publicaciones

OBISPO BUSTAMANTE 3

26001 Logroño (España-Spain)

Tel. 41-244811 / Fax: 41-259431

PUBLICACIONES DEL COLEGIO

UNIVERSITARIO DE LA RIOJA

UNIVERSIDAD DE ZARAGOZA

LOGROÑO 


\section{Dicenda \\ Cuadernos de Filología Hispánica}

Revista fundada en 1981, y publicada por los departamentos de Filología Española I y II de La Universidad Complutense. Aparece una vez al año y publica trabajos de investigación en el ámbito de la lengua y la literatura españolas.

Director: Nicasio Salvador Miguel

Redacción: Departamento de Filología Española II

Facultad de Filología (Edificio B)

Universidad Complutense

28040 Madrid

\section{Índice del número 8 (1989)}

\section{Sumario}

El teatro histórico modernista de inspiración medieval, por José Manuel Cabrales Arteaga

La difusión de Oliveros de Castilla: apuntes para la historia editorial de una historia caballeresca, por Miguel Ángel Frontón

Enunciación y estilo épico en el Libro de buen amor: algunos aspectos de la polifonía textual, por José Luis Girón Alconchel

Notas para el estudio de las imágenes en el Libro de buen amor, por María Morrás Antonio Llorente como historiador de la lingüística, por José Polo

El conector argumentativo pues, por José Portolés

Perfil lingüístico y literario de Ferrant Sanchéz de Calavera, por Alicia Puigvert Ocal Invención y diseño del receptor femenino en las Novelas a Marcia Leonarda de Lope de Vega, por Asunción Rallo Gruss

Dos fábulas burlescas de Narciso: la de Juan del Valle y Caviedes y la de Pedro Silvestre, por Yolanda Ruiz Esteban

Santa Juana de Castilla: Galdós dramaturgo revisionista de la historia española, por

Theodore Alan Sackett

Sonatas y Esperpentos, por Domingo Ynduráin 


\title{
ESPAÑA CONTEMPORÁNEA Revista de Literatura y Cultura
}

\author{
Directores: \\ SAMUEL AMELL y JOSÉ CARLOS MAINER \\ Directores adjuntos: \\ VICENTE CANTARINO, SALVADOR GARCÍA CASTAÑEDA \\ y SANTOS SANZ VILLANUEVA
}

Consejo Asesor:

María Dolores Albiac, Sergio Beser, Manuel Durán, Antonio Elorza, Alberto Gil Novales, John Kronik, Joan Lluis Marfany, Pilar Miró, Randolph Pope, Carlos Rojas, Leonardo Romero Tobar, Fanny Rubio, Enrique Ruiz Fornells, Francisco Ruiz Ramón, Andrés Sánchez Robayna, Donald Shaw, Philip Silver, Gonzalo Sobejano, Ignacio Soldevila y Stephen Summerhill.

España Contemporánea se ocupa de la literatura y la cultura españolas de los siglos XIX y XX. Intenta renovar el interés en la historia de la literatura y de la cultura con los nuevos enfoques que aportan la semiótica, la estética de la recepción, la literatura comparada, las nuevas orientaciones en historia general (historia de las mentalidades) y los nuevos horizontes epistemológicos (historia de la literatura como institución, historia del libro, etc.).

La revista se publica dos veces al año, en invierno y primavera, e incluye artículos, notas y reseñas en inglés y español. El costo de la suscripción anual es de 12 dólares ( 1.500 pesetas) para particulares y 16 (2.000 pesetas) para instituciones.

España Contemporánea está interesada en trabajos que, sin mengua del necesario rigor documental (es decir, evitando el ensayismo ligero) se sustenten en una hipótesis seria y lleguen a una conclusión que puede ser renovadora, por más polémica que parezca.

Deben enviarse dos copias de los estudios que se sometan a consideración. Si tienen notas deberán ir al final del texto. Se recomienda que los artículos no sobrepasen 25 páginas mecanografiadas a doble espacio y las notas 10 páginas. Se aceptarán dibujos, grabados u otras ilustraciones si son útiles al estudio. Los trabajos se someten al informe de especialistas del Consejo Asesor designados por los directores.

Los artículos y notas que provengan de Europa deberán enviarse a José Carlos Mainer, Director, España Contemporánea, Departamento de Literatura Espanola, Facultad de Filosofía y Letras, Universidad de Zaragoza, 50071 Zaragoza (España).

Suscripciones, libros para reseñar y artículos y notas que no procedan de Europa deberán enviarse a Samuel Amell, Director, España Contemporánea, Department of Romance Languages, The Ohio State University, 1841 Millikin Road, Columbus, $\mathrm{OH} 43210$, U.S.A. 


\section{ESTUDIOS DE LINGÜÍSTICA}

\section{UNIVERSIDAD DE ALICANTE (ESPAÑ)}

Revista anual dedicada a la difusión de investigaciones lingüísticas y publicada por la Sección de Lengua Española y Linguística General de la Universidad de Alicante.

\section{ISSN 02127636}

\section{N.6, 1990}

ARTÍCULOS : Y. Malkiel: Esbozos de dos estudios de lexicología diacrónica; R. Trujillo: Sobre la supuesta despronominalización del relativo; A. Vera Luján: Para una caracterización tipológica de los textos constitucionales (a propósito de los textos constitucionales iberoamericanos); R. Meyer-Hermann: Sobre algunas condiciones pragmáticas de la posición del sujeto en español; J. Albert-Galera: El texto, lugar de encuentro de la semiótica; A. Arias Barredo: Género gramatical y motivación semántica; E. M. Bravo García: Anotaciones sobre el uso de las formas el y estel ese / aquel como femeninos; J. L. Cifuentes Honrubia: Sobre la homologación de semiótica y pragmática: a propósito de un soneto de Góngora; M. C. Díaz Bautista: Gramática y estilística de los tropos; M. R. Hernández: Variacionismo y adquisición de una segunda lengua: estudio de una comunidad francófona; $\mathrm{L}$. Sánchez Corral: El nombre propio como imagen semiótica del referente; A. Vilarnovo: Coherencia textual; ¿coherencia interna o coherencia externa? NOTAS Y RESEÑAS: J. Polo: Roman Jakobson/1988 (Obras selectas, I) crítica externa; A. I. Navarro Carrasco: F. Moreno Fernández (recop.), Estudios sobre la variación linguística, Servicio de Publicaciones de la Universidad, Alcalá de Henares, 1990; A. I. Navarro Carrasco: M. Alvar, El envés de la hoja, Diputación Provincial, Institución «Fernando el Católico», Zaragoza, 1982; M. L. Masía Canuto: A. Vera Luján, Las construcciones pronominales pasivas e impersonales en español, Murcia, Universidad de Murcia, 1990. SUMMARIES.

Coordinación: Ana Isabel Navarro Carrasco José Luis Cifuentes Honrubia

Redacción: Departamento de Lengua Española

Facultad de Filosofía y Letras

Universidad de Alicante

Campus de San Vicente

Apdo. Correos no 99

E-03080 ALICANTE 


\section{Hispania}

A QUARTERLY JOURNAL DEVOTED TO THE INTEREST OF THE TEACHING OF SPANISH AND PORTUGUESE

THEODORE A. SACKETT, Editor DEPARTAMENT OF SPANISH AND PORTUGUESE UNIVERSITY OF SOUTHERN CALIFORNIA LOS ANGELES, CA 90089-0358

(213) $740-1275$

$740-1276$

Published by the American Association of Teacher of Spanish \& Portuguese.

Membership in the AATSP includes your subscription for HISPANIA.

Subscription rates:

Send subscription to:

Individuals $\$ 30.00$

Full time students $\$ 15.00$
James R. Chatham

Executive Director, AATSP

Mississipi State University

Mississipi State, MS 39762-6349 


\section{HISPANIC REVIEW}

\section{DESDE 1933 LA MEJOR REVISTA HISPÁNICA DE ESTADOS UNIDOS}

Crítica, historia literaria, lingüística Cuatro números anuales (más de 500 páginas)

Director: Rusell P. Sebold. Subdirectores: Oreida Chú-Pund, Ignacio Javier López. Redactores: Marina S. Brownlee, Peter G. Earle, Augusta Espantoso de Foley, Paul M. Lloyd, José Miguel Oviedo, José M. Regueiro, Jorge Salessi.

Subscripciones individuales: \$25,50 (dólares USA) al año.

Bibliotecas y otras instituciones: $\$ 35.50$.

Dirigirse a: Hispanic Review, William Hall, University of Pennsylvania, Philadelphia, PA 19104-6305, USA. 


\section{REVISTA ALICANTINA DE ESTUDIOS INGLESES}

\section{Special issue devoted to English Language Teaching Edited by Enrique Alcaraz Varó}

\section{ISSN 0214-4808 CODEN RAEIEX}

\section{№ 4, November 1991}

INTRODUCTION, by Enrique Alcaraz Varó - ESSAYS: A Reappraisal of Motivation: The Cornerstone of $L^{2}$ Learning, by José Castro Calvín; E.S.P.: Fact or Fiction?, by Winifred Crombie and Powhiri Rika-Heke; The Role of Morphology in the Process of Language Acquisition and Learning, by Joaquín A. Domínguez; Why Listening to English is Difficult for Spanish Students, by John K. Eastman; Literature in the Teaching of English as a Foreing Language, by Jenny Elliott de Riverol; English Teacher Education: The Need for a New Perspective, by Celia Florén Serrano; Reduction, Fusion and Raising in English and Spanish, by Francisco Garrudo Carabia; Self-Assessment in Second Language Teaching: Journals, by María José Martínez Azorín; Two Case Studies of Community Language Learning with Possible Implications for the Natural Order Hypothesis, by Ray Parker; ContentBased Teaching: A Methodological Approach, by Rodríguez Torras: Keys for a Investigation into the Origins of the Communicative Methodology in Language Teaching, by Aquilino Sánchez; Stress and Rhythm in English, by Maria-Josep Solé Sabater; Literature as Study and Resource: The Purposes of English Literature Teaching at University Level, by Jesús Zaro Vega - BIBLIOGRAPHICAL SECTION: A Bibliographical Approach to English Language Teaching, by José Mateo and María José Huesca; Reviews and Notes - TRANSLATION: Poems by Robert Burns, translated by Brian Hughes and F. Javier Torres Ribelles; Poems by William Wordsworth, translated by Tomás Ramos Orea; Poems by Anne Sexton and Silvia Plath, translated by J. I. Oliva.

\section{Manuscripts, books for review, and subscriptions}

Revista Alicantina de Estudios Ingleses, Secretaría, Departamento de Filología Inglesa, Universidad de Alicante, 03080 ALICANTE (España) 


\section{REVISTA DE HISTORIA MODERNA. ANALES DE LA UNIVERSIDAD DE ALICANTE}

Revista fundada en 1980 y publicada por el Departamento de Historia Moderna de la Universidad de Alicante. Periodicidad anual.

Director: Enrique Giménez López

Secretario: Armando Alberola Romá

Redacción: Dpto. de Historia Moderna

Facultad de Letras

Universidad de Alicante

03080 ALICANTE (España)

Índice del no 10: Aspectos de la vida cotidiana en la España Moderna (I): I. AMOR PROFANO Y AMOR DIVINO (DELINCUENTES, ESTUDIANTES Y RELIGIOSOS). Pablo PÉREZ GARCÍA: Un aspecto de la delincuencia común en la Valencia pre-agermanada: la "prostitución clandestina (1479-1518): Margarita TORREMOCHA HERNÁNDEZ: Las noches y los dias de los estudiantes universitarios (Posadas, mesones $y$ hospederías en Valladolid S. XVI-XVIII; Francisco PONS FUSTER: Mujeres y espiritualidad: Las Beatas Valencianas del Siglo XVII; José Luis SANTONJA CARDONA: De Vita Regulari: los frailes agustinos en el Alcoy del siglo XVIII; Cayetano MAS GALVAÑ : Un Seminario español del Barroco.

II. AL SERVICIO DE LA MONARQUÍA. CINCO BIOGRAFÍAS COLECTIVAS. Ana GUERRERO MAYLLO: La vida cotiana de los regidores madrileños de la segunda mitad del siglo XVI; Virginia LEÓN SANZ: Los españoles austracistas exiliados y las medidas de Carlos VI (1713-1725); Enrique GIMÉNEZ LÓPEZ y Jesús PRADELLS NADAL: Servir en Aragón: los corregidores de Borja en el siglo XVIII; María del Carmen IRLES VICENTE: Los regidores valencianos. Perfil sociológico de una élite de poder: Jesús PRADELLS NADAL: Los consules españoles del siglo XVIII: caracteres profesionales y vida cotidiana.

III. VARIA. Armando ALBEROLA ROMÁ: El torno a la política revisionista de Felipe $V:$ los fletamentos de buques extranjeros en el puerto de Alicante, y su empleo en la expedición a Sicilia del año 1718. 


\section{STUDIES IN TWENTIETH CENTURY LITERATURE}

A SPECIAL ISSUE ON CONTEMPORARY SPANISH POETRY: 1939-1990

Guest Editor: Andrew Debicki

University of Kansas

Hall Center for the Humanities

Andrew Debicki: Introduction-Critical Perspectives on Contemporary Spanish Poetry

José Olivio Jiménez: Fifty Years of Contemporary Spanish Poetry (19391989)

Judith Nantell:The Quest(ioning) of Epistemological Ground:The Generation of 1956

John Wilcox: A Reconsideration of Two Spanish Women Poets: Angela Figuera and Francisca Aguirre

Guillermo Carnero: Culturalism and the "New" Poetry. A Poem by Pedro Gimferrer

Margaret Persin: Pere Gimferrer's "Los espejos"

Ignacio Javier López: Language and Consciousness in the Poetry of the "«Novísimos"

Biruté Ciplijauskaité: Recent Poetry and Essential Word

Sharon Keefe Ugalde: The Feminization of Female Figures in Spanish Women's Poetry of the 1980's

Studies in Twentith Century Literature published semi-annually by Kansas State University and the University of Nebraska, is devoted to literary theory and practical criticism, with exclusive emphasis on twentieth-century literature written in French, German, Russian and Spanish. Manuscripts are welcome; they should be between 2025 pages, and preparated in acordance with the MLA Style Manual (1985). Manuscripts must be English, but quotations may be given in the original. Subscriptions are $\$ 15$ for individuals, $\$ 20$ for institutions. The single issue price is $\$ 10$.

Manuscripts on German and Russian literatures, as well as subscription request should be sent to:

Editors, STCL

Department of Modern Languages 104 Eisenhower Hall

Kansas State University Manhattan, KS 66506-1003
Manuscripts on French and Spanish literature and advertisements should be sent to:

Editors, STCL

Department of Modern Languages

Oldfather Hall

University of Nebraska, Lincoln

Lincoln, NE 68588-0318 



\section{COLABORADORES DE ESTE NÚMERO}

Jovita Boves Naves. Doctora en Filología Románica por la Universidad de Oviedo. Catedrática de Lengua y Literatura Españolas en el Instituto de Bachillerato "Aramo" de Oviedo. Autora de Las novelas "caribes" de Francisco Ayala, tiempo y espacio (1988). Artículos en Archivum y otras publicaciones periódicas.

José Luis Calvo Carilla. Profesor Titular en la Universidad de Valladolid. Sus investigaciones están orientadas hacia la literatura de los siglos XIX y XX. Además de diversas colaboraciones en revistas especializadas, ha publicado los libros El modernismo literario en Aragón (1989), Introducción a la poesía de Manuel Pinillos (1989), Braulio Foz en la novela del siglo XIX (1991) y Quevedo y la Generación del 27 (De inminente aparición) así como las ediciones de las revistas modernistas Azul y Ambiente.

Marta Cristina Carbonell. Profesora ayudante del Departamento de Filología Española de la Universidad de Barcelona, donde ultima su tesis doctoral sobre Juan Pablo Forner y la tradición crítico-satírica. Ha publicado diversos trabajos sobre la crítica literaria del último cuarto del siglo XIX (Manuel de la Revilla, Urbano González Serrano) y es la editora del Homenaje al profesor Antonio Vilanova, publicado por la Universidad de Barcelona en 1989.

Jorge Demerson. Catedrático Honorario de la Universidad Lyon II, investigador del Instituto de Estudios Canarios (Tenerife). Ha publicado: Meléndez Valdés et son temps (1962); Meléndez Valdés, traducción del anterior (1971), 2 vols; Correspondance de Meléndez sur la réunion des hôpitaux d'Avila (1964); La sociedad económica de Ávila (1968); La sociedad económica de Valladolid (1969); Sociedades económicas: Guía del investigador (en colaboración, 1974); La Reforma cultural en Francia (en colaboración, 1974); Las Iglesias de Ibiza y Formentera (1974); Leyendas de Ibiza (1976); Ibiza y su primer obispo (1980); Diario inédito de Pierre 
Paris (1978); Obra en Verso de Meléndez (en colaboración, 2 vols., edic. crítica, 1981-82); González Posada (1984); D. José de Lugo (1988). ExConsejero Cultural de Francia en España, Académico Correspondiente de las Academias Española y de la Historia, Gran Cruz de Alfonso X el Sabio, Comendador de la Orden de Isabel la Católica, Colaborador de Bull. Hisp., Insula, Cuadernos Hispanoamericanos, Rev. Estud. Extremeños, Bull. Musées Lyonnais, Arch. Esp. de Arte, Archivum, Anales Instit. Est. Madril., Bol. Soc. Vascong., Bol. Real Acad., Boces XVIII, Eivissa.

Eva F. Florensa. Profesora de Lengua y Literatura Españolas en la Universidad de Pennsylvania, Filadelfia. Interesada en la evolución de la novela desde el siglo XVIII al Realismo y, en especial, en las raíces propiamente hispánicas del género a lo largo de tales períodos literarios. Asistente del Consejo Editorial de Hispanic Review. Introducción y edición crítica de El sombrero de tres picos de Pedro A. de Alarcón (próximamente en Editorial Crítica-LEHT).

Jordi Gracia. Profesor ayudante en el Departamento de Filología Española de la Universidad de Barcelona. Ha publicado el libro La pasión fría. Lirismo e ironía en la novela de Benjamín Jarnés (Zaragoza, 1988, Premio I Centenario Nacimiento B. Jarnés). Ha colaborado en el Boletín de la Biblioteca Menéndez Pelayo, en Diálogos Hispánicos de Amsterdam, España Contemporánea, Anthropos, Revista de Catalunya, etc.

Librada Hernández. Recibió el doctorado en Letras Hispánicas en 1987 de la University of California en Los Angeles. Allí actuó de editora de la revista Mester. Desde 1987 trabaja en Furman University (Carolina del Sur). Ha colaborado en Explicación de Textos Literarios, Revista Iberoamericana $y$ Review of the Americas.

Gregory B. Kaplan. Estudiante de Doctorado en Literatura Española en la Universidad de Pennsylvania, Filadelfia. Interesado en la literatura de los judíos y conversos de la época medieval y, en especial, la poesía de los conversos del siglo XV. Presentó en agosto de 1990 una tesina, en Bowling Green State University, titulada: Judaic Themes in Representative Works of Rodrigo Cota and Juan Álvarez Gato, converso Poets of the Last half of the Fifteenth Century.

Renata Londero. Licenciado en Idiomas y Literaturas Extranjeras en la Universidad de Udine con una tesis de análisis semiótico-comparativo sobre la relación literaria entre Luis Cernuda y los románticos ingleses. Becaria del gobierno español en la Univ. Complutense.

Josep María Sala Valldaura. Catedrático de bachillerato en excedencia, y profesor de Literatura española en el "Estudi General de Lleida", de la Universidad de Barcelona. Autor de La fotografía de una sombra. (Instantáneas de la generación poética de los cincuenta) y de Los sainetes de González del Castillo en el Cádiz de finales del siglo XVIII, en curso de publicación. Introd. y ed. de J. I. González del Castillo, El aprendiz de 
torero y otros sainetes, en Estudios Escéncios, 19 (1975), pp. 103-183. Ed. y Pról. de Joan Vinyoli, Alguien me ha llamado (trad. de José Agustín Goytisolo), 1986. Artículos aparecidos, o de inminente aparición, en Anuario de Filología, Caligrama, Cuadernos Hispanoamericanos, Cuadernos para Investigación de la Literatura Hispánica, Ideas'92 (Univ. de Miami), Insula, Revista Hispánica Moderna, Scriptura, Syntaxis, etc.

Rusell P. Sebold. Catedrático de Literatura Española en la Universidad de Pennsylvania (Filadelfia) y director de la Hispanic Review en la misma. Es doctor honoris causa por la Universidad de Alicante. Fue becario de la Guggenheim Foundation, del American Council of Learned Societies y de la American Philosophical Society. Entre libros de crítica Iiteraria y ediciones comentadas, Sebold es autor de veinte volúmenes sobre el siglo XVIII y el Romanticismo. Los clásicos editados por Sebold son: Torres Villarroel, Visiones y Vida; Isla, Fray Gerundio; Luzán, Poética; Ignacio López de Ayala, Numancia destruida y Tomás de Iriarte, Comedias. Es autor de El rapto de la mente. Poética y poesía dieciochescas (1970), Cadalso: el primer romántico «europeo» de España (1974), Novela y autobiografía en la «Vida» de Torres Villarroel (1975), Trayectoria del Romanticismo español. Desde la Ilustración hasta Bécquer (1983) y Descubrimiento y fronteras del Neoclasicismo español (1985). De 1985 son también su Gustavo Adolfo Bécquer y su edición crítica de la Vida de Torres. Posteriormente, ha publicado su libro Bécquer en sus narraciones fantásticas (1989), la segunda edición de El rapto de la mente, su edición de las Rimas de Bécquer (1991), y reediciones de sus ediciones de las Visiones de Torres (1991) y Fray Gerundio del P. Isla (1992). Es asimismo autor de numerosos artículos y reseñas en las revistas Hispania, Archivum, Hispanic Review, Papeles de Son Armadans, Insula, Cuadernos Hispanoamericanos, Bulletin Hispanique, Nueva Revista de Filología Hispánica, Revista Canadiense de Estudios Hispánicos, Kentucky Romance Quarterly, etc. y en homenajes y tomos colectivos. 



\section{NORMAS PARA LA PRESENTACIÓN DE ORIGINALES DESTINADOS A ANALES DE LITERATURA ESPAÑOLA (UNIVERSIDAD DE ALICANTE)}

Estas normas resultan de la necesidad de unificar la presentación de los originales para facilitar el trabajo de la imprenta. Rogamos a nuestros colaboradores que las lean atentamente antes de redactar sus trabajos. No disponemos de personal dedicado a la corrección o adaptación de originales, y lamentaremos tener que devolver aquellos que no se adapten a estas normas, para que sean nuevamente mecanografiados.

1. Cada artículo deberá ir encabezado por su título en mayúsculas, y por el nombre de su autor (apellidos en mayúscula) seguido del de la Universidad o institución a que pertenezca, en el lado derecho del folio. Título y autor no deberán ir en hoja aparte sino en la primera del texto.

2. Todo el texto, incluidas las notas y bibliografía, deberá escribirse a doble espacio, sin cortar palabras al final de línea. No deberán existir adiciones o correcciones manuscritas. Revise la legibilidad de su original antes de enviarlo.

3. Las citas extensas y que deban aparecer exentas se mecanografiarán con márgenes mayores que el texto, dejando antes y después doble espacio interlineal, a dos espacios y sin comillas. No las transcriba nunca a un espacio. Las citas englobadas en el texto irán entre comillas.

4. Aunque las notas aparecerán impresas a pie de página, en el original deberán mecanografiarse en folios aparte y a dos espacios. Las llamadas, en números volados y sin paréntesis.

5. Las notas al pie se reservan para comentario o excursos. No se usarán para indicaciones de referencia a páginas de fuentes o elementos bibliográficos. Esas referencias se harán en el cuerpo del texto y entre paréntesis, sea cual sea su extensión, y en ellas se mencionará, por este orden: apellido del autor, obra por su año tal como venga en la bibliografía (nunca por su título completo o abreviado), y páginas cuando se quieran citar. Ejemplo: (Pérez López 1937b, págs. 19-21). Este mismo sistema se usará cuando las citadas referencias aparezcan en las notas a pie de página. 
6. La bibliografía deberá figurar al final en hojas aparte, y tendrá que incluir todos los elementos bibliográficos citados en el texto y notas, sin excepción. Se ordenará del siguiente modo:

- por orden alfabético de apellidos de autores, que se escribirán en mayúsculas, seguidos del nombre de pila en minúsculas (no use mayúsculas en las referencias de las que trata el punto cinco de estas normas).

- cuando se citen varias obras de un mismo autor, éstas aparecerán por orden cronológico de primera publicación, pudiéndose indicar después publicaciones posteriores. Si ha de mencionar el nombre del editor de un texto ajeno, ponga nombre y apellidos en orden natural, y estos últimos en mayúsculas.

- si hubiera más de una publicación del mismo año, distíngalas desde la primera con letras minúsculas en orden alfabético.

En la bibliografía las entradas deberán figurar con los datos bibliográficos completos. Si se trata de libros: apellidos, nombre, año, título, editor en su caso, ciudad, editorial o imprenta. Si de artículos: apellidos, nombre, año, título, nombre de la revista (no abreviado), tomo y número, páginas. Si de capítulos de libro: apellidos, nombre, año, título, título del libro precedido de en, datos bibliográficos del libro, páginas que ocupa el capítulo. Si el primer dato bibliográfico de ese libro es su título, estará Vd. indicando que todo él es obra del autor citado por el capítulo. Cuando se esté refiriendo a obras colectivas, indique antes del título el nombre del recopilador si lo hay, o AA.VV. (autores varios). Recuerde que los títulos de libro y nombres de revista deben ir subrayados, y los de artículo o capítulo entre comillas.

Ejemplo:

PÉREZ LÓPEZ, Antonio. 1937 a. "El teatro lírico", Revista de Filipinas VII, 2, págs. 123-141; en Estudios literarios, Madrid, Halcón, 1948, págs. 80-96; y en Antonio GÓMEZ GÓMEZ (ed.), Puntos de vista, Barcelona, Lux, 1973, págs. 95-119.

—. 1937 b. "Ópera y zarzuela", Revista de España XXX, 1, págs. 3-29.

Si maneja una obra en una edición que no es la primera, pero desea hacer constar la fecha de ésta, indique entre corchetes la fecha de la primera edición del siguiente modo:

VELÁZQUEZ, Luis José. [1754] 1989. Orígenes de la poesía castellana, ed. Antonio PÉREZ LÓPEZ, Salamanca, Universidad.

Observe que en la enumeración de datos bibliográficos se usa punto tras nombre y año, usándose comas en los demás casos.

7. Si su texto va dividido en apartados, titúlelos en minúscula y con doble subrayado, para que se impriman en negrita.

8. Cuando quiera resaltar una palabra o frase en el texto use subrayado, 
que indica cursiva. Use comillas sólo para la cita literal de otro texto. No use nunca comillas simples. Tampoco comillas, sino subrayado, dentro de comillas. La omisión de parte de un texto citado se indicará mediante tres puntos suspensivos entre corchetes; no use otro sistema. Si cita poemas, no inicie todos los versos con mayúscula (aunque así lo haga el original del que copia); use mayúscula sólo cuando lo exija la puntuación.

9. No ponga punto antes de comillas o de llamada de nota, sino después, usando la siguiente secuencia: ... moaxajas"20 y no éstas: ... moaxajas." o. ${ }^{20}$. Tanto en el texto de su artículo como en las notas, no transcriba nunca un texto a dos columnas, aunque conste de versos cortos; use dos columnas sólo cuando quiera enfrentar dos textos diferentes.

10. Si cita textos o títulos que en su original usan ortografía arcaica, queda en libertad de mantenerla o modernizarla; pero adopte un criterio único a lo largo de todo su artículo, bibliografía y notas incluidas.

11. Para la reproducción de material gráfico es imprescindible que nos envíe fotografía brillo de tamaño no menor que $18 \times 24 \mathrm{cms}$., o negativo. 



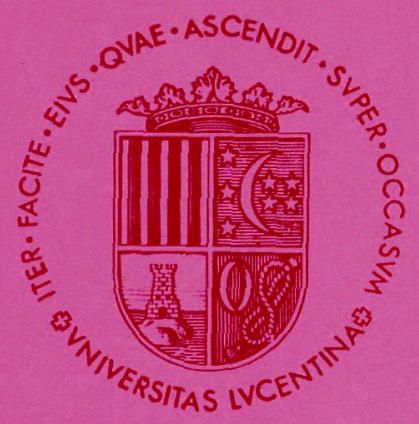

